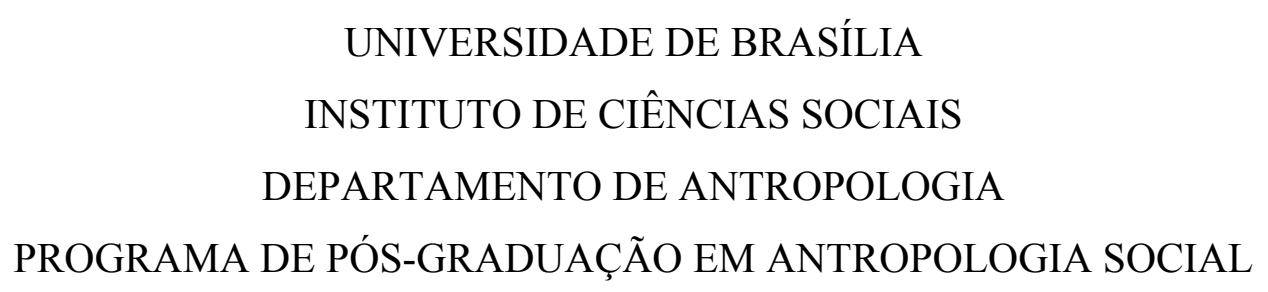

JULIANA FRANÇA VARELLA

MEDIDAS SOCIOEDUCATIVAS EM MEIO ABERTO:

PERSPECTIVAS A PARTIR DE UMA UNIDADE DE ATENDIMENTO DO DISTRITO FEDERAL

Brasília

2015 


\section{MEDIDAS SOCIOEDUCATIVAS EM MEIO ABERTO: PERSPECTIVAS A PARTIR DE UMA UNIDADE DE ATENDIMENTO DO DISTRITO FEDERAL}

Dissertação de mestrado apresentada ao Programa de Pós-Graduação em Antropologia Social da Universidade de Brasília, como parte dos requisitos para a obtenção do título de Mestre em Antropologia.

ORIENTADOR: Daniel Schroeter Simião

Brasília 


\section{AGRADECIMENTOS}

Agradeço à minha mãe, pelos momentos de conversa sobre a vida - à grande distância geográfica, mas grande proximidade de coração - em que me motivava para continuar este trabalho e "ficar firme". E pelos momentos essenciais de reflexão antropológica mesmo quando já exaustas ao telefone. À minha irmã, pela companhia, ouvidos e cuidados com a casa, que me pouparam grande tempo para que me dedicasse à dissertação. Agradeço também pelos almoços e sua preocupação em que estivessem do meu agrado, forma tão deliciosa e especial de demonstração de afeto. Às minhas avós, mulheres tão diferentes e tão únicas, que de tempos em tempos, cada uma a seu modo, enchem de sonoridade e alegria a minha casa quase sempre quieta e vazia.

Ao meu namorado, por estar sempre ao meu lado, com carinhos e palavras doces que tanto me confortaram nos momentos de aflição, e por insistir na minha capacidade de realização deste trabalho mesmo quando nos meus momentos mais descrentes. Agradeço também à sua família, pelo prazer da convivência e pela acolhida.

Às amigas de graduação da UnB, ao lado de quem comecei a trilhar minha trajetória acadêmica e que permaneceram em minha vida, compartilhando risadas, histórias, sonhos, viagens e angústias pessoais e profissionais. Às amigas que conquistei (e que me conquistaram) também fora da $\mathrm{UnB}$, que foram igualmente importantes nessa caminhada, incentivando-me a persistir nos meus objetivos e sendo companhias imprescindíveis nos momentos de lazer.

Aos colegas do Departamento de Avaliação da Secretaria de Avaliação e Gestão da Informação do Ministério do Desenvolvimento Social e Combate à Fome, pela empatia e por se disporem a me ouvir e a me ajudar e, em especial, à minha chefia, pela compreensão de que o mestrado se constitui de momento ímpar da formação acadêmica e profissional, sem a qual teria sido indubitavelmente mais difícil concluir esse trabalho.

Aos colegas do PPGAS/DAN/UnB, por partilharem os momentos de formação teórica, de estudos, e de descobertas sobre a vida acadêmica. Aos integrantes e participantes do CAJU, Laboratório de Estudos de Administração de Conflitos e Justiça do DAN/UnB, pelas contribuições teóricas, indicações bibliográficas e disponibilidade à reflexão.

Aos docentes do DAN, pelos ensinamentos, em especial à professora Cristina Patriota, que me guiou no início da condução deste trabalho, e ao meu orientador, 
Daniel Simião, pelo compartilhamento de ideias, orientação na dissertação e confiança de que, apesar dos vários percalços, eu seria capaz de finalizá-lo com êxito.

Agradeço ainda aos professores Luís Roberto Cardoso de Oliveira, Carla Teixeira e Patrice Schuch pela disponibilidade de participarem da banca de avaliação. 


\section{RESUMO}

O presente trabalho discute as diferentes perspectivas acerca das medidas socioeducativas em meio aberto - Liberdade Assistida e Prestação de Serviços à Comunidade - a partir dos discursos de técnicos que trabalham em uma UAMA Unidade de Atendimento em Meio Aberto - do Distrito Federal, bem como de um exsocioeducando e de responsáveis legais atendidos na referida Unidade. A pesquisa de campo se valeu de entrevistas, conversas informais e observação participante em eventos conduzidos neste equipamento público. Foram percebidas variações no que tange às técnicas de governo e formas de administração de adolescentes autores de atos infracionais compreendidas como mais eficazes pelos atores ouvidos, que vão desde visões tutelares, disciplinares e repressivas até noções que privilegiam a liberdade de escolha dos sujeitos, sua emancipação e autonomia. Discute-se ainda a experiência de conversão religiosa do ex-socioeducando e sua consequente mudança de conduta de vida por meio da observação de palestras feitas por ele e voltadas para os adolescentes atendidos na UAMA. O trabalho desenvolvido permitiu identificar categorias que orientam a prática dos profissionais em questão bem como as experiências dos atores envolvidos com o sistema socioeducativo no DF. A pesquisa ponderou ainda que esses entendimentos diversos levam a conflitos de expectativas entre os atores ouvidos, o que abre possibilidades de reflexão acerca dos movimentos recentes de resistência à perspectiva emancipatória e garantista prevista no Estatuto da Criança e do Adolescente - ECA.

Palavras-chaves: medidas socioeducativas em meio aberto; técnicas de administração de adolescentes autores de atos infracionais; conversão religiosa. 


\begin{abstract}
The present study discusses the different perspectives about socio-educative measures for adolescents in conflict with the law that don't deprive them of their freedom assisted freedom and community services - by analyzing the discourses of the professionals that work at the service unit called UAMA, in the Federal District of Brazil, as well as by analyzing the point of view of an young man who has been himself an user of the socio-educative services and by considering the perspectives of the parents of the adolescents that attend the abovementioned Unit. During the fieldwork, interviews, informal conversation and participant observation of events that took place at the referred public equipment were conducted. The researcher was able to perceive variations with respect to the government techniques and management strategies of the adolescents accused of having committed infraction acts that were considered by the agents as being more or less effective. These techniques and strategies reveal, on one hand, tutelary, disciplinary and repressive visions, and on the other, notions that privilege the freedom of choice of the subjects, their emancipation and autonomy. The study also discusses the religious conversion experience of the young man mentioned above and his consequent change in behavior by observing the talks given by him to the adolescents assisted at the Unit. The work that was developed here allows us to identify the categories that guide the practice of the professionals in question as well as the experiences of the actors involved in the socio-educative policy in Brazil. The research reasoned that theses diverse understandings end up leading to conflicts of expectations among the actors, which opens the possibilities for reflection about the recent movements, in Brazil, of resistance to the emancipatory perspective provided in ECA The Brazilian Child and Adolescent Statute.
\end{abstract}

Keywords: socio-educative measures; techniques for the administration of adolescents accused of infraction acts; religious conversion. 


\section{SUMÁRIO}

LISTA DE ABREVIATURAS E SIGLAS ..............................................................8

INTRODUÇÃ

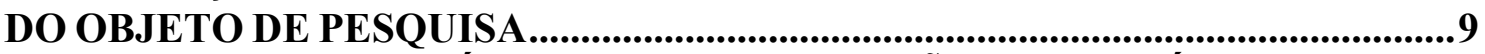

PRINCIPAIS EIXOS TEÓRICOS E ORGANIZAÇÃO DOS CAPÍTULOS ............14

CAPÍTULO 1 - MEDIDAS SOCIOEDUCATIVAS NO BRASIL, CONTEXTO

HISTÓRICO, LEGISLAÇÃO E INSTRUMENTOS DE AÇÃO - SITUANDO O

LEITOR.

CAPÍTULO 2 - ENTRADA EM CAMPO: A UNIDADE, OS PROFISSIONAIS E

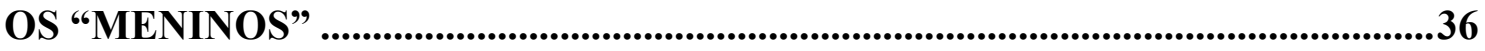

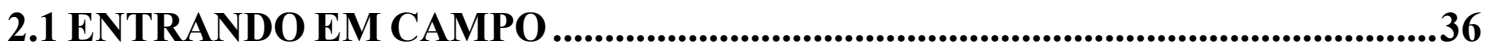

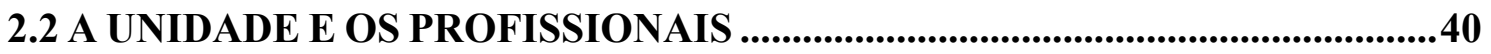

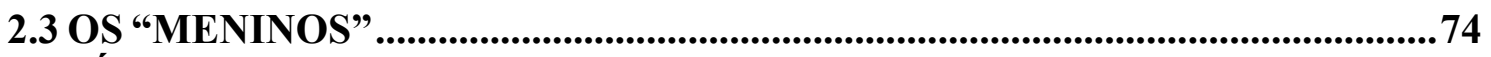

CAPÍTULO 3 - O EX-SOCIOEDUCANDO CONVERTIDO .................................85

3.1 - "SÓ EXISTE MUDANÇA SE VOCÊ ABRIR O SEU CORAÇÃO PRA ELE"

3.2 - RAFAEL : “QUEBRANDO ASESTATÍSTICAS",

CAPÍTULO 4 - SOBRE "MUDANÇA DE VIDA": ENTENDIMENTOS E

EXPECTATIVAS ACERCA DA GESTÃO DAS TRAJETÓRIAS DE VIDA DOS

ADOLESCENTES EM MEDIDAS SOCIOEDUCATIVAS..................................114

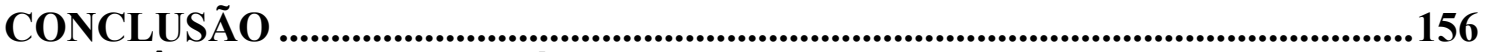

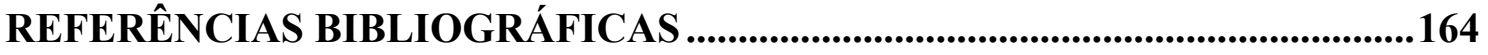




\section{LISTA DE ABREVIATURAS E SIGLAS}

ATRS: Atendente de Reintegração Socioeducativo

CAJE: Centro de Atendimento Juvenil Especializado

CAPS: Centro de Atenção Psicossocial

CIEE: Centro de Integração Empresa Escola

Codeplan: Companhia de Planejamento do Distrito Federal

Conanda: Conselho Nacional dos Direitos da Criança e do Adolescente

CRAS: Centro de Referência de Assistência Social

CREAS: Centro de Referência Especializado de Assistência Social

ECA: Estatuto da Criança e do Adolescente

LA: Liberdade Assistida

MDS: Ministério do Desenvolvimento Social e Combate à Fome

MSE: Medidas Socioeducativas

PIA: Plano Individual de Atendimento

PSC: Prestação de Serviços à Comunidade

SDH/PR: Secretaria de Direitos Humanos da Presidência da República

SINASE: Sistema Nacional de Atendimento Socioeducativo

TJDFT: Tribunal de Justiça do Distrito Federal e Territórios

UAMA: Unidade de Atendimento em Meio Aberto

VIJ: Vara da Infância e da Juventude 


\section{INTRODUÇÃO}

\section{DO OBJETO DE PESQUISA}

Em 1990, no Brasil, foi promulgado o Estatuto da Criança e do Adolescente ECA -, lei $\mathrm{n}^{\circ} 8.069 / 90$, mais uma expressão de que os campos legislativo e judicial brasileiros têm buscado acompanhar e constituir o processo de democratização política e o retorno do Estado de direito após anos de regime militar. Legalmente, esse esforço se deu por meio da expansão dos dispositivos de proteção aos direitos individuais democráticos (SCHUCH, 2005). No "regime repressivo", era dominante a política da "segurança nacional" sobre os direitos dos cidadãos, e o poder do judiciário era reduzido.

A Constituição Federal de 1988, nesse sentido, resgatou esse poder e consolidou os direitos políticos, sendo vista também como "instrumento de mudança social", tendo nascido no "bojo da emergente retórica universalista dos 'direitos humanos', que, como indicou Dumont (1983), dependeu do processo de construção de uma noção de indivíduo enquanto uma "ideia-valor" central na modernidade ocidental. O movimento internacional ecoou no Brasil fazendo-nos entender a promulgação do ECA como uma extensão de direitos individuais - agora ampliados e consolidados - aos cidadãos menores de 18 anos.

A consolidação de direitos individuais das crianças e adolescentes no Brasil ocorreu em um momento de disseminação global dos "direitos da criança", na esteira de legislações internacionais de proteção dos direitos da criança e do adolescente. Por meio do ECA, foi desenvolvida a noção de "proteção integral”, que já estava presente no artigo 227 da Constituição, para suplantar a "doutrina da situação irregular" das legislações anteriores, que possuíam "caráter tutelar e discricionário, pautando seus princípios pela ideia do controle social".

Sobre a ideia de direitos humanos na modernidade, Berger (1983) lembra que, para a consciência moderna, é o self solitário, o indivíduo, independentemente da classe a que pertença ou dos atributos que carregue, que tem sido percebido como portador de dignidade humana e de direitos humanos inalienáveis. A dignidade, ao contrário da honra - conceito que o autor vê como obsoleto na modernidade - relaciona-se sempre à 
humanidade intrínseca e alienada das normas e papéis impostos socialmente ao indivíduo e que independe de sua posição na sociedade.

A partir do ECA, legislação guiada pelos valores dos direitos humanos, foi afirmada a condição de "sujeito de direitos" das crianças e adolescentes (SCHUCH, 2005). As transformações ocorridas desde então, como menciona Schuch, foram de conteúdo, de método e de gestão. No que se refere ao conteúdo, ela cita a organização e hierarquizações das ações em políticas sociais básicas, políticas assistenciais e política de proteção especial"; no que tange ao método, ela menciona a "substituição do assistencialismo vigente por um conjunto de trabalho socioeducativo emancipador"; por fim, no que diz respeito à gestão, a autora fala da introdução do princípio da descentralização administrativa e democratização das políticas.

No âmbito deste trabalho, interessa-me especialmente falar dos "métodos" para se administrar crianças e adolescentes, principalmente da perspectiva de profissionais que trabalham com adolescentes que cometeram atos infracionais no Distrito Federal (DF) com que tive contato para desenvolver essa pesquisa. Os profissionais esboçaram entendimentos diferenciados a esse respeito, que, por sua vez, contrastaram com as perspectivas de responsáveis legais dos adolescentes atendidos e de um exsocioeducando com quem tive a oportunidade de conversar.

O trabalho de Schuch (2005) alerta-nos para a importância de compreendermos o "processo de implementação de uma lei na multiplicidade de sua existência: como um processo necessariamente dinâmico de produção de significados por agentes sociais". Alinhada a essa perspectiva, a presente pesquisa foi desenvolvida com o objetivo de compreender as percepções e as práticas de trabalho de profissionais de uma Unidade de Atendimento em Meio Aberto (UAMA) no Distrito Federal, local que recebe e atende adolescentes que cometeram atos infracionais e que devem cumprir dois tipos das chamadas "medidas socioeducativas:” Liberdade Assistida (LA) e Prestação de Serviços à Comunidade (PSC). Para o desenvolvimento deste trabalho, tive a oportunidade de conversar com os técnicos que realizam os "atendimentos" com os adolescentes, com as supervisoras da unidade, participar de oficinas com adolescentes e pais, conversar com

\footnotetext{
1 Schuch escreve em 2005, antes de ter sido publicada a Tipificação Nacional de Serviços Socioassistenciais, documento que data de 2009. Atualmente, os serviços socioassistenciais estão tipificados em três grandes categorias: proteção social básica, proteção social especial de média complexidade e proteção social especial de alta complexidade. Para mais informações, acessar http://www.mds.gov.br/assistenciasocial/protecaobasica/servicos/projovem/arquivos/tipificacaonacional.pdf/download
} 
um "ex-socioeducando" e com um dos responsáveis pela coordenação do trabalho de jovens em PSC em uma instituição executora desta medida e, por fim, assistir a alguns "atendimentos", momentos em que os "educadores sociais" - psicólogos, pedagogos e assistentes sociais - conversam com os jovens e os orientam visando a "alteração de sua trajetória"2, em especial para que estes não voltem a cometer atos infracionais e se mantenham estudando e trabalhando, quando for o caso.

O trabalho de campo foi realizado durante o primeiro semestre de 2015 , e os dados que serão apresentados neste texto são fruto não apenas de entrevistas e conversas guiadas, mas também de momentos em que pude participar de um compartilhamento de ideias espontâneo com os técnicos - em especial técnicas, uma vez que a presença feminina é absolutamente majoritária nesse campo - que se mostraram muito receptivos e dispostos ao diálogo durante o período em que os visitei em seu ambiente de trabalho, repleto de "casos", "relatórios" e "meninos".

Quando adentrei o campo desse equipamento público, a UAMA, eu buscava compreender os sentidos dados à experiência com as medidas socioeducativas pelos profissionais que com elas trabalham. Uma das estratégias traçadas foi assistir aos atendimentos. Entretanto, uma dificuldade surgida em campo foi a da obtenção de termos de consentimento dos responsáveis legais dos adolescentes para que eu participasse dos atendimentos. Isso só era possível quando o responsável estava presente, o que ocorria com mais frequência no momento do primeiro atendimento do jovem, denominado de "acolhimento". Por essa razão, a minha participação nos momentos de atendimento aos jovens ficou limitada. Eu já possuía a autorização da juíza da Vara de Execução de Medidas Socioeducativas do Distrito Federal para visitar duas UAMAS do DF, o que, entretanto, não me foi possível, devido ao tempo que tinha disponível e às múltiplas possibilidades que o campo em apenas uma delas me abriu, o que fez com que eu precisasse diminuir o escopo do trabalho inicialmente previsto para que de fato conseguisse me aprofundar nas questões que se apresentavam, além de conseguir me aproximar dos profissionais da UAMA primeiramente visitada.

Entender o sentido do trabalho dos profissionais com quem conversei, como pude perceber, envolvia conhecer a trajetória de cada um, os limites e possibilidades que viam em sua atuação com os adolescentes, tendo em vista a sua compreensão dos objetivos da política social e o modo como se organizava a prática de trabalho na

\footnotetext{
${ }^{2}$ Os termos se encontram entre aspas por serem categorias nativas do campo em estudo. A mesma estratégia será usada em outros momentos ao longo do texto.
} 
Unidade. Importante dizer que o presente trabalho não visou a "avaliar" a atuação dos técnicos, tampouco o serviço, cotejando a prática encontrada com as normas vigentes a seu respeito. Em vez disso, essa pesquisa visou, sobretudo, compreender como e quais categorias são acessadas pelos profissionais para desenvolverem seu trabalho na unidade. Nas conversas com os profissionais identifiquei uma série de termos que são próprios da atuação na área da assistência social e que se remetem, de fato, a orientações que esse serviço de execução de medidas socioeducativas em meio aberto deve contemplar. Entretanto, minha preocupação se deu em entender a forma como os profissionais se apropriavam desses termos, como entendiam o sentido de sua atuação na vida dos jovens que gostariam de mudar, ou melhor, de orientar para a mudança.

Interessa-me tentar explicar os discursos dos profissionais sobre a sua atuação na UAMA, pensando em termos, por exemplo, de seu entendimento acerca do que deve ser a política socioeducativa e a construção do sujeito que dela emerge, numa perspectiva que se aproxima do que foi descrito por Rifiotis (2014) ao tratar da temática dos debates em torno dos Direitos Humanos. Para Riofiotis, o "sujeito de direitos" é uma chave analítica que resume mais do que uma "titularidade de direitos". Essa categoria, "sujeito de direitos", tal como a percebe o autor, remeteria a uma construção histórica e analítica característica do movimento teórico e política da "volta do sujeito". Ele acrescenta que a partir de 1980, nas ciências sociais, essa volta se torna um marco importante, por recolocar o lugar do sujeito, isto é, a "relação entre a estrutura e a 'intervenção humana"" (p. 124).

Refletir na chave do sujeito, diz o autor, e em especial na de sujeito de direitos, implica resgatar a ação e as práticas sociais como elementos centrais da análise (p. 125) e, resgatando Ortner (2005), ele menciona a ideia de que a subjetividade está na base da agência, que seria parte necessária do entendimento de como as pessoas agem (ou tentam agir) sobre o mundo e como este age sobre elas. Nessa perspectiva, a agência não seria algum desejo natural ou originário, mas sim conformada nos moldes de desejos específicos e intenções dentro de uma matriz de subjetividade de sentimentos, pensamentos e significados culturalmente constituídos (p. 125). Ele afirma que no mundo moderno a constituição da legitimidade das relações sociais está fundada principalmente no direito, à qual o sujeito de direitos estaria intimamente ligado (p. 126). Nessa perspectiva, a "lei" é concebida como mecanismo de mudança social, de promoção de cidadania, etc, mas, ressalta Rifitois, essa ênfase na normatividade apenas reforça as impossibilidades de sua plena realização, que é justificada por motivos como 
a falta de recursos materiais ou institucionais ou mesmo por questões "culturais", entendidas como a inadequação entre o texto legal e as práticas sociais (p. 127).

Para Riofitis, falar de sujeito de direitos significa "voltar a atenção analítica e política para o sujeito como operador, avaliador, integrador de múltiplas perspectivas e formulador de modos de ação coerentes com a sua perspectiva" (p. 130). O autor se preocupa em estudar a "dimensão vivencial dos Direitos Humanos", o que ele chama de "o sangue e a carne" dos direitos, em alusão ao trabalho de Malinowski. Junto com tratados, convenções ou leis, diz Rifiotis, há sempre sujeitos que deles se apropriam e os legitimam e que não são operadores do Direito no sentido estrito. Ele completa que "é sobre essa classe de sujeitos que devemos voltar a nossa atenção analítica e política. Pois são eles com suas experiências e posturas ideológicas diversificadas que dão vida aos Direitos Humanos" (p. 130).

No trabalho que desenvolvi, têm lugar central os operadores do sistema socioeducativo na "ponta", isto é, os educadores sociais, sujeitos que agem guiados não só pela normatividade do ECA, mas também por percepções próprias e sentidos que conferem à sua atividade com os adolescentes, os "sujeitos" aos quais se destinam "os direitos". Assim, não lidei com os próprios sujeitos de direitos de que fala o ECA, os adolescentes em medidas socioeducativas, mas sim com sujeitos que fazem a intermediação entre a normatividade da lei e os seus agentes finais, os adolescentes, por meio de uma prática de interação social face-a-face. Como fala Rifiotis, "a figura do 'sujeito de direitos' é uma bandeira que aponta numa direção inequívoca: a dimensão vivencial da normatividade, com as suas múltiplas e divergentes leituras", o que, em meu caso, tentei captar por meio do discurso dos profissionais e das oficinas de que participei, haja vista a impossibilidade de assistir a um número razoável de atendimentos com a presença dos adolescentes e pelo interesse em perceber os múltiplos entendimentos dos técnicos acerca dos "métodos" mencionados acima.

As perguntas que primeiro me guiaram para a entrada no campo do sistema socioeducativo foram: como se dá o processo de um adolescente pelo sistema socioeducativo? Como os profissionais operam junto aos adolescentes para que alcancem o que eles entendem ser o objetivo de seu trabalho? Como eles enxergam o trabalho que fazem, qual o seu sentido, o que guia a sua ação frente ao "menino" que está diante deles? Quais discursos parecem orientar a prática dos profissionais da socioeducação? Afinal, o que é a socioeducação nos discursos que orientam as práticas dos profissionais? Quais as subjetividades que subjazem às atitudes de aplicação da 
normatividade no cotidiano de uma Unidade de Atendimento em Meio Aberto? Com quais "configurações de sujeito" eu iria me deparar?

Além de ter tido a oportunidade de perceber nuances de interpretação acerca do papel da socioeducação e diferentes matrizes de subjetividade que diferenciavam os profissionais, pude acessar também as visões acerca das medidas socioeducativas tal como proferidas por responsáveis legais dos adolescentes atendidos e também de um ex-socioeducando. O tempo dispendido na unidade, que envolveu entrevistas, conversas informais e a participação em oficinas, possibilitou-me, tal como entendo, caminhar da "letra fria" da lei para a sua "carne e sangue", por meio da apreensão de discursos sobre experiências, práticas, percepções e expectativas dos atores que fizeram parte desta etnografia.

Como destaca Schuch (2005), é relevante assumir como "práticas" fundamentais os discursos, o que se chamaria de a construção de um ideal. Assim, alinho-me à autora no sentido de compreender os discursos dos profissionais como "práticas e espaços para a constituição e disputa de significados", numa "concepção foucaultiana sobre o discurso como um dos elementos do 'real' e não como um 'ideal suprarreal', em torno do qual práticas sociais efetivas seriam avaliadas em termos de sua adequação" (p. 4445).

\section{PRINCIPAIS EIXOS TEÓRICOS E ORGANIZAÇÃO DOS CAPÍTULOS}

Alguns eixos teóricos importantes dizem respeito a uma perspectiva mais abrangente, que faz alusão à própria forma de estudar políticas públicas, a exemplo da política de medidas socioeducativas para adolescentes autores de atos infracionais, trazendo para reflexão a noção de população enquanto cerne da atuação dos governos atuais (BURCHON et al, 1991). A emergência da noção de população possibilitou conceber a arte de governo fora de um modelo de "administração de uma família", fazendo da família um instrumento fundamental do que Foucault chama de um governo de populações, sendo concebida agora como um elemento dessa população. No caso em estudo, a relação do Estado, na figura dos profissionais, com as famílias é vista como uma das portas de entrada para a transformação da conduta dos adolescentes, por meio dos trabalhos de construção ou reconstrução de vínculos afetivos, por exemplo, ou de trabalhar, como me diziam meus interlocutores, "a questão da autoridade dos pais frente 
aos filhos". Além desses conceitos, interessa-me também a noção de técnicas do self, que envolvem as capacidades auto-reguladoras de sujeitos "normalizados" por meio de poderes de expertise e que têm se tornado recursos chave para as formas modernas de governo e estabelecido condições cruciais para governar de uma forma liberal democrática (SHORE \& WRIGHT, 2005).

Nesse sentido, o ECA pode ser pensado como um marco moderno importante que diferencia um período em que se tinha legislações baseadas na tutela e que tinham como forma de ação a disciplina e um outro momento, que conta com um modelo novo de atuação sobre crianças e adolescentes e que privilegia a liberdade dos sujeitos, tanto no que se refere ao fato de agora se privilegiarem as medidas em meio aberto, isto é, a liberdade "física" dos sujeitos, quanto ao fato de apostarem na liberdade, no sentido de uma racionalidade neoliberal, de fazerem as suas próprias escolhas, tendo por base um modelo pedagógico ancorado, sobretudo, em um trabalho que visa criar sujeitos que façam "boas escolhas", estando essas frequentemente relacionadas a uma atitude que evita a rua, as drogas, e que privilegia o trabalho e a educação formal, explicados em termos "técnicos" como portas de saída da trajetória de cometimento de atos infracionais às quais estariam ligados os sujeitos em questão.

Schuch (2008) fala de "processos que investem na formação de sujeitos éticos enquanto indivíduos ativos e aptos a maximizar a qualidade de suas vidas por meio de atos de escolha e liberdade". Esses processos, diz a autora, podem ser relacionados, com a expansão de uma racionalidade específica, que é dita "neoliberal", pois investe na escolha como um valor fundamental de governo e desenvolve tecnologias para instalar e apoiar o "processo civilizador do governo das capacidades, competências e desejo dos sujeitos". A autora entende que no contexto brasileiro o desenvolvimento dessa racionalidade neoliberal se relaciona com a introdução da linguagem dos direitos e com a necessidade de constituir "sujeitos de direitos" com "novas habilidades para a cidadania, fundamentalmente abarcadas pelo autogerenciamento da conduta" (SCHUCH, 2008, p. 3).

Vale ressaltar que nesse processo de formação de novos sujeitos éticos que investigo, a categoria de "sentido" foi fundamental e acessada diversas vezes pelos profissionais para se referirem à atitude dos adolescentes atendidos, diferenciando os jovens em dois grupos: os que veem "sentido" nas medidas socioeducativas e nos marcos objetivos que vêm com elas (como frequentar a escola e trabalhar), identificando nelas, portanto, uma "oportunidade" para que mudem de fato; e os jovens 
que as enxergam apenas como uma obrigação ou uma "pequena consequência" do ato que cometeram, não se mobilizando de fato no sentido de uma alteração de atitude e mudança de vida. Além da noção de sentido, acessada pelas profissionais, foi forte a menção à vida religiosa como forma de mudar os adolescentes. $\mathrm{O}$ apego à religião surgiu a partir da fala de um ex-socioeducando que entrevistei e que ofereceu uma "oficina" a adolescentes em cumprimento de medidas na UAMA que visitei e a seus responsáveis legais.

A respeito da transformação de conduta dos adolescentes almejada pelos profissionais, pode-se trazer o conceito de "processo civilizador", de Norbert Elias (1991), que associa os processos de modernização especialmente à construção de um self auto-contido e à regulação das condutas. O processo civilizador que moldou as sociedades modernas ocidentais como as conhecemos hoje tem ocorrido desde a Idade Média. O autor nos mostra como ao longo desse processo uma subjetividade moderna foi sendo construída e como a própria ideia de indivíduo, tão importante para as legislações que se têm hoje no mundo todo, foi tomando corpo.

Elias faz um estudo acerca de como se constrói historicamente a estrutura de sentimentos do "homem civilizado", diferente daquela da Idade Média, por meio do que chama de "processo civilizador", relacionando a transformação da estrutura políticoeconômica - de princípios da Idade Média à constituição das sociedades ocidentais sob a forma de Estados - com a transformação da mentalidade humana e dos sentimentos no sentido de uma maior regulação da conduta e dos impulsos, que aos poucos vai sendo internalizada. $\mathrm{O}$ autor nos mostra que muitos sentimentos que se julgava serem instintivos, como o nojo, o medo e a vergonha, foram, na verdade, construídos por esse processo civilizador. Os padrões de decoro corporal externo foram se tornando mais rígidos e as restrições às emoções, mais intensas.

Com o aumento da diferenciação das funções sociais e, logo, da interdependência entre as pessoas, havia necessidade de que suas condutas fossem sintonizadas, de modo que o controle sobre suas ações devesse ser mais rígido. $\mathrm{O}$ modelo de controle de emoções necessário ao trabalho profissional diferia daquele imposto pela função de cortesão, percebe-se, então, uma divisão da vida humana em esferas profissional e privada e como a transformação da estrutura social ocorreu junto à transformação da estrutura da personalidade. O guerreiro cedia a seus impulsos e não pensava nas consequências, mas nas formas posteriores de sociedade isso passou a ser 
punido, e a previsão do futuro, limitação e controle mais estritos da manifestação de emoções e grau mais alto de autocontrole individual passaram a ser exigidos.

Com o monopólio da força, o indivíduo passa também a reprimir seu impulso emocional para atacar fisicamente outra pessoa, a violência física passa a ser socialmente condenável e a própria violência toma formas mais sutis. Com espaços sociais apaziguados, diminuem os medos externos, mas aumentam os internos. $\mathrm{O}$ controle das condutas sociais passa ser instilado no sujeito cada vez mais cedo, saindo do nível da consciência e transformando-se numa espécie de automatismo, uma "segunda natureza", e gerando uma oposição entre o homem civilizado, capaz de controlar as suas paixões, e o homem bárbaro, que não as controla.

Assim, os profissionais da UAMA fomentam uma ideia de "um adolescente que tem que cuidar de si”, do self auto contido e reflexivo, e buscam o modelo do cidadão "consciente", aquele que já introjetou em si como se deve comportar, controlando sua agressividade e minimizando os conflitos, nesse caso, em especial na família, para que os vínculos de afeto e de respeito sejam fortalecidos com os parentes, na escola, mas sobretudo, na comunidade, por meio de evitar, por exemplo, adentrar locais em que ele tenha "guerra" com outros adolescentes, ou, nas palavras dos profissionais, rixas, do que depende, inclusive, a sua integridade física.

No que tange ao método para levar às mudanças de conduta, sugiro pensar em um híbrido constituído por dois tipos de técnicas disciplinadoras de governo: de um lado, técnicas embasadas em mecanismos de vigilância e de correção, e mais alinhadas a uma noção de punição mais severa pelo ato cometido, e, por outro lado, técnicas orientadas para uma noção de indivíduo livre para fazer as suas escolhas, mas que deve saber como fazer "boas escolhas", e, por isso, a necessidade da orientação dos profissionais junto aos adolescentes e suas famílias. Ainda com relação ao método, é possível interpretar os discursos dos profissionais valendo-se do contraste feito por Dumont (1983) entre a ideologia holista e a individualista, que se refletem em discursos de tutela, por um lado, e de emancipação dos indivíduos por outro. Por vezes os discursos dos técnicos se alinham mais à primeira, quando eles se sentem mais responsáveis pelas escolhas dos jovens e pelos "desvios dos caminhos corretos" que eles venham a pegar. Por outras, alinham-se à ideologia individualista, de caráter moderno, quando os profissionais esboçam com maior clareza o limite de sua atuação, pensada em termos de uma orientação e, como tal, incapaz de fazer com que os 
adolescentes mudem, mas sim capaz de orientá-los a isso, cabendo a eles a total responsabilidade pelas suas escolhas.

Durante o campo, pude observar dois polos em tensão: um que entendia a transformação pela repressão e um que via a transformação pelo desenvolvimento da autonomia de um sujeito de direitos. De um lado, discursos no sentido de um modelo tutelar em que se julga que o sujeito não é confiável ou não sabe o que quer, em que se tem a noção mais de uma culpabilização e não de uma responsabilização; e, de outro lado, discursos que se ancoram no modelo emancipatório e garantista. No primeiro, fala-se de um não-cidadão, indivíduo não-autônomo e não-responsável, de um Estado responsável pela mudança do outro, pois o Estado sabe o que é melhor para os indivíduos, tidos como pessoas hipossuficientes, o que seria uma característica de sociedade hierárquica, isto é, em que a pessoa tem uma obrigação com o todo enquanto parte desse todo. Pude perceber essa tensão especialmente no que tange à expectativa das famílias e ao trabalho dos profissionais - em alguns casos, entre os próprios profissionais - em que as primeiras pareciam entender o processo de educação como afirmação de autoridade e esperavam dos profissionais da UAMA uma postura mais rígida com relação aos seus filhos e os últimos viam os atendimentos enquanto um processo de criação de sujeitos reflexivos e por meio de uma parceria Estado-famíliaadolescente. Havia, portanto, duas representações diferentes no campo e ideologias que por vezes entravam em choque, ocorrendo, por isso, um choque de expectativas no que tange ao serviço prestado pelos profissionais da UAMA.

A categoria da "responsabilização" foi uma das primeiras que me saltou os olhos durante o trabalho de campo, especialmente por estar relacionada à noção de uma compreensão de consequência, por parte dos adolescentes, em relação ao ato infracional cometido e pela ênfase das profissionais na importância de sua verdadeira compreensão para a alteração da trajetória dos adolescentes. À responsabilização, soma-se a categoria "sentido", mencionada pelas profissionais como categoria mobilizadora da mudança e que estaria relacionada tanto à compreensão da medida socioeducativa cumprida como "uma resposta à sociedade" quanto à importância do trabalho e da escola, dois termos ditos essenciais para que haja uma mudança de vida dos adolescentes e que pode ser ainda conectada à noção de "autoestima" e "valorização da pessoa", numa perspectiva de que a estima do indivíduo dependeria, dentre outros fatores, de seu posicionamento na sociedade, como estudante, como trabalhador, o que, por sua vez, modificaria também a forma como ele é visto perante a sua família. 
Outra dimensão muito presente no discursos dos profissionais diz respeito aos perigos que representa a rua com suas "más influências", dois fatores que são trazidos à tona durante os atendimentos como uma preocupação, pois teriam força para prejudicar a alteração de trajetória de vida buscada com o cumprimento da medida socioeducativa na UAMA. A rua é acessada pelos responsáveis dos adolescentes em termos de um contraste com a casa, do qual já nos falou DaMatta (1997), afinal, o espaço, diz o autor, precisa de um sistema de contrastes para ser concretizado.

A rua, no Brasil, é entendida como local em que devem viver os malandros, os meliantes, os pilantras e os marginais em geral - as más influências de que falam os meus interlocutores - ainda que esses mesmos personagens possam ser seres humanos decentes e até mesmo "bons pais de família”. DaMatta lembra que os locais, casa e rua, não designam apenas espaços geográficos, mas também entidades morais. Entretanto, é necessário ver que a oposição casa/rua não é estática e absoluta, mas dinâmica e relativa, porque se reproduzem mutuamente, uma vez que há espaços na rua que podem ser fechados ou apropriados por um grupo, categoria social ou pessoas, tornando-se sua “casa", ou o seu "ponto", o que fica explícito no discurso dos adolescentes que veem a rua como um local de encontro com amigos e de lazer. Nos discursos dos meus interlocutores, responsáveis legais e educadores sociais, contrastam com a rua também o espaço da escola e da igreja, e esta última, como pretendo mostrar, é associada a uma entidade moral forte capaz de fomentar a mudança de atitude dos adolescentes perante a vida.

Os discursos desses jovens acerca da "rua", aliás, foi o que primeiro me despertou a atenção no que diz respeito ao tema das medidas socioeducativas. Por ser ocupante do cargo de Analista Técnico de Políticas Sociais e, em especial, por fazer parte de uma secretaria responsável pela avaliação de políticas do Ministério do Desenvolvimento Social e Combate à Fome (MDS), pude acompanhar uma pesquisa conduzida com o intuito de avaliar o serviço de proteção social prestado a adolescentes em medidas socioeducativas de Liberdade Assistida e Prestação de Serviços à Comunidade nos chamados CREAS, Centros de Referência Especializados de Assistência Social, que trabalham com indivíduos e famílias em situação de ameaça e/ou violação de direitos ${ }^{3}$. Acompanhar essa pesquisa de avaliação me possibilitou acessar alguns discursos dos adolescentes "em medidas", o que me revelou um campo

\footnotetext{
${ }^{3}$ No Distrito Federal, tal serviço é ofertado nas chamadas UAMAs, Unidades de Atendimento em Meio Aberto.
} 
de estudos que pareceu muito fértil e interessante. Cabe pontuar, entretanto, que o trabalho que pretendo desenvolver nessa dissertação não tem, ao contrário do faço em minha atividade profissional no MDS, um caráter avaliativo, mas busca a compreensão do objeto em questão.

Inicio o texto, no primeiro capítulo desta dissertação, abordando o panorama em que se inserem as medidas socioeducativas no Brasil, trazendo à baila alguns marcos legais e históricos, introduzindo o leitor à compreensão de sua implementação e da forma de funcionamento das medidas em meio aberto, do cometimento do ato ao atendimento na UAMA. No segundo capítulo, exploro com mais detalhe a minha entrada em campo, apresentando os "personagens" dessa etnografia, descrevendo a forma de trabalho como relatada pelos profissionais e o perfil dos adolescentes em medidas socioeducativas, no DF e na UAMA visitada, por meio da exposição de alguns dados produzidos à pedido da Secretaria de Estado da Criança, órgão gestor do Sistema Socioeducativo no DF. No terceiro capítulo, apresento e analiso um evento que presenciei na unidade: a palestra de um "ex-socioeducando", quem chamo de "convertido", para tratar da temática da mudança de trajetória de vida, abordando especialmente a convergência de uma mudança de vida no sentido que é esperado pelos profissionais da Unidade, mas também num sentido de conversão religiosa, o que é central na trajetória deste personagem, como será visto. No quarto capítulo, busco desenvolver a noção, em um paralelo com o capítulo anterior, de uma "mudança de vida", mostrando a aproximação entre os sentidos da política em questão, como proferidos pelos profissionais, e valores de uma modernidade ocidental e técnicas de governo, além de explorar categorias que gravitam entorno da tão desejada "mudança" dos adolescentes, como responsabilização e sentido, escola e trabalho, más influências e a rua. Por fim, nas considerações finais, retomo os objetivos do trabalho e as categorias que lhe foram mais caras para mostrar, finalmente, como se articulam as diversas dimensões exploradas pela pesquisa e como elas podem contribuir para algumas outras reflexões.

Espero que esse trabalho possa lançar luz sobre as formas pelas quais as técnicas de administração de adolescentes autores de atos infracionais vêm sendo pensadas na ponta pelos profissionais que lidam com a execução de medidas socioeducativas, pelo jovem com grande tempo de experiência dentro do Sistema Socioeducativo e ainda por responsáveis legais dos adolescentes atendidos, de modo que se visualize a complexidade desse campo e que seja compreendido o lugar de cada discurso dentro 
dele. Creio ainda que o que está posto aqui possa, no futuro, servir de subsídio para trabalhos que versem sobre movimentos atuais, em especial os que vêm sendo desenvolvidos no Congresso Nacional e noticiados pela mídia, que vão de encontro com as propostas presentes no ECA e na própria Constituição Federal brasileira. 


\section{CAPÍTULO 1 - MEDIDAS SOCIOEDUCATIVAS NO BRASIL, CONTEXTO HISTÓRICO, LEGISLAÇÃO E INSTRUMENTOS DE AÇÃO - SITUANDO O LEITOR}

Como pontua Schuch (2006), novos princípios, orientações e linguagens vêm sendo empreendidos no Brasil desde os anos 1980 como um esforço para adequar as legislações e estruturas judiciais ao contexto democrático. Os campos legislativo e judicial brasileiros, diz ela, vêm acompanhando e constituindo o processo de democratização política e o retorno do Estado de direito. Como exemplos desses novos princípios e orientações, ela cita a própria Constituição Federal de 1988 e leis que se inspiram em legislações de proteção de direitos, como o Estatuto da Criança e do Adolescente, sancionado em outubro de 1990, e a Lei Orgânica da Assistência Social, de dezembro de 1993. Schuch busca tematizar o processo de implementação das transformações nos aparatos jurídico-estatais de atendimento à infância e juventude especialmente, aqueles referentes às políticas socioeducativas, destinadas aos chamados "adolescentes autores de ato infracional" - que têm na mudança da lei, com a promulgação do ECA em 1990, a sua justificativa fundamental (p. 57). A mudança em prática, afirma Schuch, diz respeito não somente a uma tentativa de transformação de instituições e discursos, mas de sensibilidades e afetos (p. 58). Em seu modo de vista, a principal contribuição antropológica seria a passagem da análise dos princípios formais para as práticas cotidianas da constituição dos direitos, de seus sentidos, usos, apropriações e reformulações na particularidade das experiências sociais (p. 59), o que pretendo ao menos tentar tangenciar nessa dissertação.

A análise etnográfica de Schuch faz ver que a constituição dos "direitos" dos adolescentes infratores está eminentemente inscrita por sentidos de justiça ancorados em ideais de pacificação e harmonização social (p. 59). Um dos pontos que Schuch ressalta em seu trabalho, a partir da observação de cursos de capacitação e formação profissional, é a criação de uma sensibilidade fundamental embasada na procura por valores tomados por esses agentes como "universais", a saber, a paz e o amor. Diz a autora:

Se por um lado o desejo de uma "ética global" coloca em evidência uma terapêutica de amor e de paz como solução do 'desajuste' social, por outro lado estabelece um humanismo que justifica e legitima a intervenção social, numa singular inter-relação entre aspectos técnico-pedagógicos, judiciários e religiosos. Tais valores são orientados por uma retórica do sentimento, cujo 
protagonista é um "homem transcendental", o que acaba reforçando um ideário liberal de justiça (p. 60).

Schuch lembra que as preocupações com a "delinquência", no Brasil, bem como com a insegurança pública, o desenvolvimento industrial e a urbanização crescente do Rio de Janeiro e de São Paulo começaram a caracterizar uma atenção de diferentes agentes para questões ligadas ao governo das populações [grifo meu], por volta do final do século XIX e início do século XX. No Brasil, a constituição de aparatos judiciais para a infância contou com uma aliança entre médicos e juristas e foi:

conclamada como parte de um 'movimento civilizatório' no qual a 'modernização' da justiça - através da ênfase na reabilitação do infrator - seria importante para o próprio aperfeiçoamento da população brasileira, numa perspectiva médico-higiênica também percebida em outros domínios sociais ( $\mathrm{p}$. $61)$.

A referida ligação entre médicos e juristas à época, vale lembrar, estava em voga não apenas no Brasil, mas internacionalmente, sendo discutida em congressos científicos. O primeiro "Juízo de Menores" foi criado em 1924 no Brasil. Em 1927, foi promulgado o "Código de Menores", o objeto de uma cadeia de autoridades formada por juízes, força policial, setores políticos, cruzadas médicas, associações caritativas e filantrópicas foi definido como "o menor", uma categoria ambígua, cristalizada no campo jurídico a partir do Código de Menores de 1927, mas que adveio fundamentalmente da prática policial (p. 63). Como aponta Schuch:

o "menor" era definido, primordialmente, em torno de sua situação de subordinação social pela pobreza. As medidas jurídico-estatais dirigiam-se à população carente da sociedade brasileira, objetos privilegiados das medidas de reforma populacional e alvos de um esforço classificatório de reordenamento do social, algo particularmente relevante em um momento de recente fim da escravidão (p. 63).

A "justiça de menores", diz Schuch, "colocava-se num dilema: é justiça ou é assistência social? Qual a natureza jurídica do trabalho com 'menores'? Tais perspectivas críticas ganharam fôlego através do diálogo com o contexto internacional", em que, no final da década de 1940 e início dos anos 1950, vinha discutindo a necessidade da defesa dos 'direitos' do menor e da regulamentação de sua proteção (p. $64)$. 
Até 1942, o foco da discussão da problemática da infância se colocava nos mecanismos estatais para a promoção do bem-estar da criança, na tríade criança-famíliaEstado e, diz Schuch, passou a ser a "criança como sujeito de direitos, num claro desprivilégio das ações estatais”. A partir de 1948, com a promulgação do Código PanAmericano da Criança, cristalizou-se a mudança de ênfase, isto é, de uma voltada para os esforços de reforma conduzida pelo Estado para uma que dava ênfase à relevância de programas diversos de ajuda às famílias, no intuito de que conduzissem suas próprias estratégias de sobrevivência. A abordagem individualista [grifo meu], menciona Schuch, tornou-se cada vez mais difundida em legislações e tratados internacionais. Explicitava-se, portanto, a soberania do indivíduo frente às soberanias nacionais. Também contribuiu para a difusão de uma ideia de indivíduo portador de direitos fundamentais, acima de qualquer identidade atribuída, a criação de instituições internacionais, como a ONU e o UNICEF, órgão especializado em crianças e adolescentes das Nações Unidas, chamado Fundo das Nações Unidas para a Infância (p. $64)$.

Em 1948, a ONU promulga a "Declaração Universal dos Direitos do Homem" e é aprovado o Código Pan-Americano da Criança. Em 1959, é promulgada a Declaração dos Direitos da Criança. Assim, a concepção de uma "infância universal" ganha força e é ancorada em uma noção de universalidade da natureza humana. As declarações, tanto a de direitos do homem como a dos direitos da criança, enunciam um padrão "a que todo devem 'aspirar' e se empenhar em construir'. Elas seriam uma espécie de legitimação internacional de uma forma de administração da infância e juventude que teria nos órgãos de justiça os instrumentos privilegiados de governo (p. 65). Esse contexto pôs em evidência a necessidade de, no Brasil, se debater a transformação do Código de Menores, elaborado em 1927.

No período autoritário, as políticas e as discussões voltaram-se para a proteção e defesa da 'segurança nacional, privilegiando-se uma abordagem nacional em detrimento dos debates internacionais sobre a proteção à criança. Como correlato, houve uma continuidade na linguagem das políticas jurídico-estatais em termos de bem-estar social, conjugado com a ideia de defesa social (p. 66).

A política da "Segurança Nacional" vigorou até o final do governo militar no Brasil. Em 1979, foi promulgado o novo Código de Menores, que definia o alvo das políticas como "menor em situação irregular", categoria com referência à ideia de patologia social (p. 66). Num contexto internacional de novos órgãos supra-nacionais e a implementação de novas leis de proteção à infância e juventude, e de um contexto 
interno marcado de início pela abertura política, surgem críticas acerca do caráter repressor e autoritário que a classificação "menor" e "menor em situação irregular" trazia para as políticas da infância e juventude (p. 67).

Em 1990, como resultado da mobilização nacional e internacional, é promulgado

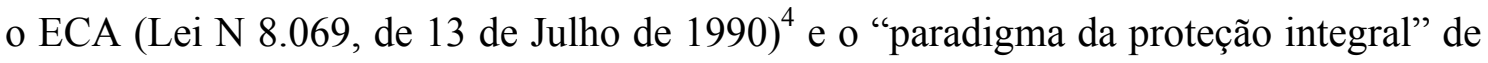
crianças e adolescentes passa a vigorar no âmbito jurídico-estatal da infância e juventude no Brasil. Dessa vez, o alvo das políticas não mais é o "menor", mas sim as crianças e adolescentes definidos como "sujeitos de direitos", seguindo a tendência da "universalização da infância" (p. 67). As políticas de atendimento passam a ser divididas em medidas de "proteção especial", para casos de abandono e maus tratos, por exemplo, e de medidas socioeducativas visando os sujeitos que cometem atos infracionais.

No contexto da América Latina, é interessante resgatar a autora argentina Mary Bellof que, em seu artigo intitulado "Los adolescentes y el sistema penal. Elementos para uma discussion necesaria en la Argentina actual", traz um breve relato sobre a origem do que ela chama de novos sistemas de justiça juvenil lationamericanos. Segundo ela, o processo de adequação da ordem jurídica dos países latino americanos à Convenção Internacional sobre os direitos da Criança faz-se importante para a compreensão do processo singular de defesa dos direitos da criança que teve lugar na América Latina. Esse processo, diz ela, inspirou-se na reforma legal ocorrida no Brasil, que havia modificado a forma de produção das leis para as crianças e adolescentes. $\mathrm{Na}$ visão da referida autora, o processo que se passou em nosso país foi original, pois teve a intenção, pelo menos em sua origem, de produzir as leis de um modo diferente, mais democrático. Ela ressalta que o Estatuto da Criança e do Adolescente no Brasil não foi produzido por experts do chamado "direito de menores", mas sim pelos atores envolvidos e comprometidos com a infância em nível nacional, como membros de organizações diversas, de profissionais ou trabalhadores, funcionários públicos, juristas, médicos, trabalhadores sociais ou qualquer outro interessado, tendo as próprias crianças e adolescentes participado desse processo, num exercício concreto de aplicação do artigo 12 da Convenção Internacional (BELOFF, 2002, p. 98-99).

A América Latina, diz Beloff, foi construindo sistemas de resposta às infrações à lei cometidas por pessoas menores de dezoito anos com modelos próprios que foram se

\footnotetext{
${ }^{4}$ Disponível em http://www.planalto.gov.br/ccivil_03/leis/18069.htm
} 
corrigindo à medida que outros países aprovavam novas leis e coletavam os acertos e erros dos que já haviam percorrido esse caminho. A autora afirma que talvez os principais atores dessas reformas nos diferentes países da América Latina não tenham consciência da originalidade nem da dimensão continental desse processo e que provavelmente nem os redatores da Convenção Internacional sobre os Direitos das Crianças nem os funcionários nacionais encarregados de sua ratificação previram o uso intenso que dela fizeram e continuam fazendo todos aqueles preocupados com a efetiva vigência dos direitos das crianças e adolescentes na região Latinoamericana. Segundo Beloff, a convicção de que, neste terreno, a reforma legal era condição necessária ainda que não suficiente - para promover mudança social não é um dado irrelevante em um continente que operou à margem da legalidade por décadas. Em dez anos, argumenta, a maior parte dos países da América Latina tem abandonado, com maior ou menor clareza conceitual, os modelos assistencialistas tutelares característicos das legislações de menores anteriores à Convenção Internacional sobre os Direitos da Criança e tem criado novos sistemas para regular a condição jurídica da infância e da adolescência (BELOFF, 2002, p. 100). De acordo com o artigo 40 do Decreto N. 99.710, de 21 de Novembro de 1990, que Promulga a Convenção sobre os Direitos da Criança no Brasil:

\section{Artigo 40}

1. Os Estados Partes reconhecem o direito de toda criança a quem se alegue ter infringido as leis penais ou a quem se acuse ou declare culpada de ter infringido as leis penais de ser tratada de modo a promover e estimular seu sentido de dignidade e de valor e a fortalecer o respeito da criança pelos direitos humanos e pelas liberdades fundamentais de terceiros, levando em consideração a idade da criança e a importância de se estimular sua reintegração e seu desempenho construtivo na sociedade.

2. Nesse sentido, e de acordo com as disposições pertinentes dos instrumentos internacionais, os Estados Partes assegurarão, em particular:

a) que não se alegue que nenhuma criança tenha infringido as leis penais, nem se acuse ou declare culpada nenhuma criança de ter infringido essas leis, por atos ou omissões que não eram proibidos pela legislação nacional ou pelo direito internacional no momento em que foram cometidos;

b) que toda criança de quem se alegue ter infringido as leis penais ou a quem se acuse de ter infringido essas leis goze, pelo menos, das seguintes garantias:

I) ser considerada inocente enquanto não for comprovada sua culpabilidade conforme a lei;

II) ser informada sem demora e diretamente ou, quando for o caso, por intermédio de seus pais ou de seus representantes legais, das acusações que pesam contra ela, e dispor de assistência jurídica ou outro tipo de assistência apropriada para a preparação e apresentação de sua defesa;

III) ter a causa decidida sem demora por autoridade ou órgão judicial competente, independente e imparcial, em audiência justa conforme a lei, com 
assistência jurídica ou outra assistência e, a não ser que seja considerado contrário aos melhores interesses da criança, levando em consideração especialmente sua idade ou situação e a de seus pais ou representantes legais; IV) não ser obrigada a testemunhar ou a se declarar culpada, e poder interrogar ou fazer com que sejam interrogadas as testemunhas de acusação bem como poder obter a participação e o interrogatório de testemunhas em sua defesa, em igualdade de condições;

V) se for decidido que infringiu as leis penais, ter essa decisão e qualquer medida imposta em decorrência da mesma submetidas a revisão por autoridade ou órgão judicial superior competente, independente e imparcial, de acordo com a lei;

VI) contar com a assistência gratuita de um intérprete caso a criança não compreenda ou fale o idioma utilizado;

VII) ter plenamente respeitada sua vida privada durante todas as fases do processo.

3. Os Estados Partes buscarão promover o estabelecimento de leis, procedimentos, autoridades e instituições específicas para as crianças de quem se alegue ter infringido as leis penais ou que sejam acusadas ou declaradas culpadas de tê-las infringido, e em particular:

a) o estabelecimento de uma idade mínima antes da qual se presumirá que a criança não tem capacidade para infringir as leis penais;

b) a adoção sempre que conveniente e desejável, de medidas para tratar dessas crianças sem recorrer a procedimentos judiciais, contando que sejam respeitados plenamente os direitos humanos e as garantias legais.

4. Diversas medidas, tais como ordens de guarda, orientação e supervisão, aconselhamento, liberdade vigiada, colocação em lares de adoção, programas de educação e formação profissional, bem como outras alternativas à internação em instituições, deverão estar disponíveis para garantir que as crianças sejam tratadas de modo apropriado ao seu bem-estar e de forma proporcional às circunstâncias e ao tipo do delito (BRASIL, 1990).

Como pontuado acima, a partir de 1990, passa a vigorar no Brasil o Estatuto da Criança e do Adolescente, o ECA. De acordo com as premissas do Estatuto da Criança e do Adolescente (ECA - Lei 8.069/90), a criança e o adolescente não mais ostentam a condição de objetos de proteção, mas de sujeitos de direitos, possuindo direitos comuns a todos os brasileiros e alguns especiais, como o direito de brincar (ROSSATO, 2011, p. 45). É o ECA também que dispõe acerca do que se chama de "ato infracional", conduta descrita como crime ou contravenção penal, praticado por adolescentes (Idem, p. 307). Crianças e adolescentes, segundo a Constituição Federal, são inimputáveis, havendo modelo diferenciado de responsabilização segundo a idade (p. 310). Às crianças só são aplicadas "medidas protetivas", ao passo que aos adolescentes, podem ser aplicadas também as "medidas socioeducativas" (p. 310). As MSE, como são conhecidas pelos agentes públicos, compreendem, a depender do julgamento da instância judiciária, uma advertência, uma obrigação de reparar o dano, a prestação de serviços à comunidade (PSC), a liberdade assistida (LA), a inserção em regime de semi-liberdade ou ainda a 
internação em um estabelecimento educacional (p. 327). Para fins de elaboração de minha pesquisa de mestrado, interessam-me particularmente apenas as medidas em meio aberto LA e PSC. O trabalho de campo para fins de produção da dissertação de mestrado foi realizada em uma UAMA, Unidade de Atendimento em Meio Aberto, equipamento responsável por receber os adolescentes encaminhados e desenvolver o Serviço de Proteção Social junto a eles no Distrito Federal. A Prestação de Serviços à Comunidade (PSC) consiste na realização de tarefas gratuitas, por um período de até seis meses em estabelecimentos como entidades assistenciais, hospitais, escolas, entre outros, bem como em programas comunitários ou governamentais. As tarefas devem ser cumpridas em uma jornada de até oito horas semanais e em dias e horários que não prejudiquem a sua frequência na escola e no trabalho. Tive a oportunidade de visitar uma das instituições vinculadas à UAMA onde fiz campo e que recebe e orienta os trabalhos dos adolescentes que cumprem PSC.

No caso do adolescente que cumpre medida de Liberdade Assistida, esse é acompanhado, auxiliado e orientado por um profissional de entidade ou programa de atendimento por pelo menos seis meses. $\mathrm{O}$ orientador deve promover socialmente $\mathrm{o}$ adolescente e sua família, fornecendo-lhes informações e inserindo-os, se necessário, em programa oficial ou comunitário de auxílio e assistência social, bem como supervisionar a sua frequência e aproveitamento escolar, promovendo sua matrícula, além de diligenciá-lo no sentido da profissionalização e inserção no mercado de trabalho e apresentar relatórios acerca do caso tratado (p. 328-9). Como pontua ROSSATO (2011) sobre o ECA:

A paz social é uma das primeiras preocupações do Estado e a sua busca se faz por meio da efetivação de intervenções de natureza preventiva e repressiva. $\mathrm{O}$ ato infracional - enquanto também manifestação de desvalor social - enseja a movimentação da máquina estatal no sentido de verificar-se a necessidade de efetiva intervenção com o objetivo de educar o adolescente e, mesmo inconscientemente, puni-lo, como estratégia pedagógica (p. 330).

Existe um paralelo entre o que o ECA chama de linhas de atendimento e a assistência social brasileira, cuja nova concepção, trazida pela Constituição Federal, visa à universalização dos acessos e da responsabilidade estatal, inserida no sistema de bem-estar social brasileiro (p. 265). A Assistência Social é exercida por meio da Proteção Social Básica e Proteção Social Especial de Média e de Alta Complexidade. Interessa no que tange aos objetivos deste trabalho, a proteção social especial de média 
complexidade. A proteção social especial se destina a "famílias e indivíduos que se encontram em situação de risco pessoal e social, por ocorrência de abandono, maus tratos físicos e, ou, psíquicos, abuso sexual, uso de substâncias psicoativas, cumprimento de medidas socioeducativas, situação de rua, situação de trabalho infantil, entre outras" (p. 266). De acordo com a Tipificação Nacional de Serviços Socioassistenciais, o Serviço de Proteção Social a Adolescentes em Cumprimento de Medida Socioeducativa de Liberdade Assistida (LA) e de Prestação de Serviços à Comunidade (PSC) se insere na proteção social especial, que lida com casos em que a situação de risco já está consolidada, e em que, entretanto, os vínculos familiares e comunitários se encontram preservados, ao contrário da Proteção Social Básica, que tem caráter inibitório, visando evitar a submissão à situação de risco e diferente também da Proteção Social Especial de Alta Complexidade, que é voltada ao indivíduo que já se encontra sem referência familiar ou que necessita ser retirado de seu núcleo familiar (p. 266). Ainda de acordo com a Tipificação Nacional, o Serviço de Proteção Social a Adolescentes em Cumprimento de MSE tem por finalidade prover atenção socioassistencial e acompanhamento a adolescentes e jovens em cumprimento de medidas socioeducativas em meio aberto, determinadas judicialmente (ROSSATO, 2011).

Para que se compreenda melhor o percurso de um adolescente que é inserido no Sistema Socioeducativo, enumero brevemente as etapas processuais - de acordo com documento disponível no sítio eletrônico do Tribunal de Justiça do Distrito Federal e Territórios (TJDFT) - pelas quais ele passa desde o momento em que é apreendido até o momento em que se inicia o seu atendimento na UAMA, no caso de adolescentes que devem cumprir medidas em meio aberto ${ }^{5}$ :

1) A primeira etapa é a policial ou investigatória, que compreende: a apreensão do adolescente pela prática do ato infracional e seu encaminhamento à Delegacia da Criança e do Adolescente (DCA), que se segue pelo auto de apreensão ou boletim de ocorrência circunstanciado, a depender do caso, momento em que há oitiva de testemunhas, vítima e adolescente e a realização de exames e perícias, terminando com o encaminhamento do adolescente ao Juiz da Vara da Infância e da Juventude para autuação e decisão quanto ao flagrante (liberação ou internação do adolescente). Isso culmina na "fase ministerial". O documento pontua ainda que "o adolescente será privado de sua liberdade em caso de flagrante do ato infracional ou por ordem escrita e fundamentada do Juiz da Infância e da Juventude, que avaliará a gravidade e a repercussão social do ato". A finalidade da internação é, segundo o texto: garantir a segurança pessoal do adolescente ou manter a ordem pública.

\footnotetext{
${ }^{5}$ Fonte: www.tjdft.jus.br/publicacoes/manuais.../medidasSocioeducativas.pdf, acesso em 15 de abril de 2015.
} 
2) Na fase ministerial, o Promotor de Justiça ouve o adolescente e, se possível, responsáveis, vítima e testemunhas e, com isso, ele pode: 1) promover o arquivamento, que é homologado pelo juiz da vara e implica em que o adolescente não cumprirá nenhuma medida socioeducativa; 2) conceder remissão com ou sem aplicação de MSE, o que também deve ser homologado pelo juiz da vara e pode levar à decisão deste por aplicar uma MSE ou não ou 3) oferecer representação contendo a descrição dos fatos e requerendo a aplicação de MSE, conforme o artigo 112 do ECA, e caminhar para a fase judicial.

3) Na fase judicial, o Juiz da Vara da Infância e da Juventude recebe a representação, designa audiência de apresentação e decide sobre a internação provisória do adolescente, que não pode ultrapassar o período de 45 dias. Os critérios utilizados nessa fase são: indícios suficientes de autoria e materialidade, além da demonstração da necessidade imperiosa da medida. Em seguida, ocorre a audiência de apresentação, em que se dá a oitiva do adolescente e de seus responsáveis, bem como a apresentação de defesa prévia com rol de testemunhas caso haja. Após essa audiência, ocorre a audiência de continuação, em que se dá a oitiva das testemunhas indicadas pelo Ministério Público e pela Defesa. Segue-se então para a fase de diligências, que compreende a juntada de documentos e a realização de novas perícias. Seguemse as alegações finais do Ministério Público e da Defesa e, por fim, o juiz profere a sentença que pode se dar pela absolvição do adolescente e posterior arquivamento do processo, ou pela aplicação de medida socioeducativa, caso demonstrado que o ato infracional ocorreu e que o adolescente foi o autor, conclusão que leva o adolescente à fase de execução da medida socioeducativa. Cabe expor também que, de acordo com o documento do TJDFT, as medidas socioeducativas do art. 112 do Estatuto da Criança e do Adolescente são aplicadas ao adolescente pelo juiz, levando-se em consideração:

a. a gravidade do ato infracional;

b. o contexto pessoal do adolescente;

c. sua capacidade de cumprir a medida a ser imposta.

A análise do contexto pessoal é subsidiada também pelo relatório social apresentado pela equipe técnica da internação provisória.

4) $\quad \mathrm{Na}$ fase de execução da sentença socioeducativa, formaliza-se o processo de execução da medida socioeducativa por meio da extração da carta de sentença; é expedido ofício à instituição responsável pelo acompanhamento socioeducativo do adolescente e este é vinculado ao programa socioeducativo e a execução da medida passa a ser acompanhada judicialmente; a equipe técnica encaminha semestralmente à $1^{\text {a }}$ Vara da Infância e da Juventude (VIJ) relatórios avaliativos da evolução comportamental do adolescente; a Vara encaminha à Promotoria de Defesa da Infância e Juventude e à Defensoria Pública (ou advogado constituído) para ciência do relatório e o processo é devolvido à $1^{\text {a }}$ VIJ; em seguida, o juiz da $1^{\text {a }}$ VIJ confronta o relatório avaliativo com o programa individual de acompanhamento socioeducativo do adolescente, avalia a sua evolução comportamental e, considerando as manifestações da Promotoria e da Defensoria (ou advogado) decide ou pela liberação do adolescente da medida ou pela continuação do acompanhamento da medida, em que o processo fica aguardando novo relatório avaliativo do comportamento do adolescente para concluir se ele está, finalmente, "apto ao convívio social", momento em que o juiz libera o adolescente da medida e a Promotoria, a Defensoria Pública e instituição executora são cientificadas, culminando com a extinção do processo de execução de MSE. 
No que diz respeito às etapas citadas acima, é importante que se recupere rapidamente a ideia de remissão. De acordo com o texto mencionado, a remissão poderá ser concedida atendendo às circunstâncias e consequências do fato, ao contexto social, bem como à personalidade do adolescente e sua maior ou menor participação no ato infracional. A remissão não implicaria, conforme o documento, necessariamente no reconhecimento ou comprovação da responsabilidade, nem prevaleceria para efeito de antecedentes. Ao entender que ao adolescente deve ser concedida uma "remissão", o juiz só poderá incluir a aplicação de uma das medidas socioeducativas em meio aberto, isto é, advertência, obrigação de reparar o dano, prestação de serviços à comunidade ou liberdade assistida. Uma das profissionais entrevistadas, uma educadora social que é psicóloga, falou-me espontaneamente da ambiguidade, segundo seu entendimento, desse conceito de remissão. Para ela, ele seria uma espécie de "perdão" ao adolescente pelo ato cometido, mas que ainda assim implicaria na aplicação de uma MSE.

Ora, se o adolescente é perdoado, por que ele ainda deve "cumprir uma medida"? A profissional me chamou a atenção especialmente pela frustração com o trabalho que exerce com os "meninos" e a remissão, conforme compreendi, seria um fator que, em sua visão, deixaria os profissionais em uma posição frágil, uma vez que, sendo frequente a concessão de remissão aos adolescentes, seguida do cumprimento da medida na UAMA em que trabalha, os seus argumentos para convencer os meninos de que é necessário comparecer à unidade para os atendimentos se fragilizam. Em outras palavras, se é difícil levar o adolescente declarado "culpado" a cumprir a medida, mais difícil ainda seria ter argumentos fortes para manter os meninos "em remissão" cumprindo corretamente as medidas.

Uma expressão frequentemente utilizada pelos jovens e que é repetida pelos profissionais constantemente é a de que a medida "não dá nada, e se der, dá bem pouquinho". Esse entendimento de que a medida socioeducativa em meio aberto não traz consequências para a vida dos adolescentes parece ter a ver com o fato de ela não trazer uma privação de liberdade. Conforme me contou essa profissional, a convivência dos adolescentes que atende na UAMA com adultos próximos que passaram pelo sistema prisional os faz crer que o cumprimento da medida equivale a ir a UAMA para "assinar", em um paralelo com a prática do livramento condicional, a que estão submetidos alguns adultos. A compreensão dos adolescentes de que as medidas "não dão em nada", segundo essa profissional, faz com que os técnicos se sintam impotentes na tarefa de garantir a presença dos meninos na unidade e, com isso, garantir que seu 
trabalho seja feito, gerando frustração ao profissional. Ela acrescentou ainda que menciona em seus atendimentos que o não cumprimento das medidas pode sim levar a consequências negativas para o jovem, para, como me disse, "pôr um medinho nele" e evitar que ele falte aos atendimentos e/ou deixe de cumprir outras prerrogativas da medida que lhe foi aplicada.

No que diz respeito aos instrumentos do sistema socioeducativo, é importante citar o Sistema Nacional de Atendimento Socioeducativo (Sinase), gerido pela Secretaria de Direitos Humanos da Presidência da República (SDH/PR) e instituído pela Lei Federal 12.594/2012 em 18 de Janeiro de 2012. O Sinase é também regido pelos artigos referentes à socioeducação do Estatuto da Criança e do Adolescente (Lei Federal 8.069/1990), pela Resolução 119/2006 do Conselho Nacional dos Direitos da Criança e do Adolescente (Conanda) e pelo Plano Nacional de Atendimento Socioeducativo (Resolução 160/2013 do Conanda) ${ }^{6}$. De acordo com o disposto na Lei 12.594/2012, § $1^{\mathrm{o}}$ :

Entende-se por Sinase o conjunto ordenado de princípios, regras e critérios que envolvem a execução de medidas socioeducativas, incluindo-se nele, por adesão, os sistemas estaduais, distrital e municipais, bem como todos os planos, políticas e programas específicos de atendimento a adolescente em conflito com a lei. ${ }^{7}$

As ações do Sinase são executadas tendo por base o Plano Nacional de Atendimento Socioeducativo, que fornece as suas diretrizes e eixos operativos ${ }^{8}$. De acordo com o sítio eletrônico da SDH, o SINASE busca enquanto sistema integrado articular em todo o território nacional os Governos Estaduais e Municipais, o Sistema de Justiça, as políticas setoriais básicas (Assistência Social, Saúde, Educação, Cultura, etc.) para assegurar efetividade e eficácia na execução das Medidas Socioeducativas de Meio Aberto, de Privação e Restrição de Liberdade, aplicadas ao adolescente que infracionou.

O sistema objetiva ainda, de forma primordial, o desenvolvimento de uma ação socioeducativa sustentada nos princípios dos direitos humanos enquanto promove

Fonte: http://www.sdh.gov.br/assuntos/criancas-e-adolescentes/programas/sistema-nacional-demedidas-socioeducativas/sistema-nacional-de-atendimento-socioeducativo-sinase-1, acesso em $15 \mathrm{de}$ abril de 2015.

${ }^{7}$ Disponível em: http://www.planalto.gov.br/ccivil_03/ ato2011-2014/2012/lei/112594.htm, acesso em 15 de abril de 2015 .

8 O referido plano está em uma publicação de 2013, disponível em: http://www.sdh.gov.br/assuntos/criancas-e-adolescentes/pdf/plano-nacional-de-atendimentosocioeducativo-diretrizes-e-eixos-operativos-para-o-sinase. 
alinhamentos conceitual, estratégico e operacional, estruturados em bases éticas e pedagógicas.

O SINASE se inspira em acordos internacionais sobre direitos humanos dos quais o Brasil é signatário e reafirma a diretriz do Estatuto sobre a natureza pedagógica da medida socioeducativa. Além disso, a SDH informa que no Sinase são priorizadas as medidas em meio aberto (prestação de serviço à comunidade e liberdade assistida) em detrimento das medidas privativas ou restritivas de liberdade em estabelecimento educacional (semiliberdade e internação), haja vista que há o entendimento de que estas somente devem ser aplicadas em caráter de excepcionalidade e brevidade. Segundo informações da Secretaria de Direitos Humanos (SDH), "trata-se de estratégia que busca reverter a tendência crescente de internação dos adolescentes bem como confrontar a sua eficácia invertida, uma vez que se tem constatado que a elevação do rigor das medidas não tem melhorado substancialmente a inclusão social dos egressos do sistema socioeducativo". Por fim, é mencionada a importância de se atuar de forma ágil na apuração do ato infracional e na inserção do adolescente no cumprimento da MSE. Para tanto, o SINASE prevê a instalação do chamado "Atendimento Inicial Integrado", também dito "Núcleo de Atendimento Integrado", o NAI, que, no Distrito Federal, foi inaugurado em fevereiro de 2013. No DF, ele é vinculado à Secretaria de Estado da Criança - secretaria que, aliás, faz a gestão das medidas socioeducativas no DF - e foi pensado para reunir num mesmo espaço físico o Tribunal de Justiça do Distrito Federal e Territórios, Ministério Público do Distrito Federal e Territórios, Defensoria Pública do Distrito Federal e Secretarias de Estado de Saúde, de Educação, de Segurança Pública e de Assistência Social, com objetivo de:

prestar atendimento imediato, eficaz, eficiente, humano e educativo ao adolescente apreendido em flagrante, a quem se atribua autoria de ato infracional, de acordo com o estabelecido no art. 88, inciso V, do Estatuto da Criança e do Adolescente - ECA, e no art. $4^{\circ}$, inciso VII, da Lei 12.594/12 SINASE $^{9}$ (Portal da Secretaria de Estado de Políticas para Crianças, Adolescentes e Juventude).

Com base nessa concepção, tem-se a Unidade de Atendimento Inicial - UAI, porta de entrada do Sistema Socioeducativo do Distrito Federal, que acolhe adolescentes pelo prazo máximo de 24 horas, realiza atendimento psicossocial e elabora o Estudo Preliminar a fim de:

a) subsidiar a decisão do Ministério Público e do Poder Judiciário;

\footnotetext{
${ }^{9}$ Disponível em: http://www.crianca.df.gov.br/component/content/article/319.htm
} 
b) acionar as demais políticas públicas de acordo com a situação sociofamiliar identificada, a partir do relato do adolescente, visando à superação das condições de "vulnerabilidade e risco".

Por sua vez, o sítio eletrônico da SDH pontua, além da proximidade física benéfica ao andamento dos processos, como visto na página da Secretaria da Criança do DF, uma aproximação ideológica e de princípios, e uma vantagem desta forma de atuação como sendo o fato de:

\begin{abstract}
se conseguir olhar para a pessoa do adolescente e não apenas para o ato infracional que ele praticou. $\mathrm{O}$ adolescente passa a ser o centro da atenção das várias áreas que de forma simultânea e efetiva poderão dar conta de atendê-lo, juntamente com sua família, em suas necessidades e direitos fundamentais ${ }^{10}$ (Portal da Secretaria de Direitos Humanos da Presidência da República).
\end{abstract}

Essas inovações no Sistema Socioeducativo, como me relataram as técnicas da UAMA que visitei, deram mais celeridade às etapas processuais que levam o adolescente até a unidade. Entretanto, foi pontuado que a distância temporal entre o cometimento de um ato e o início dos atendimentos na Unidade ainda é grande, o que dificulta a associação entre o delito cometido e o cumprimento da medida pelo adolescente. Isso interfere diretamente no trabalho de "responsabilização" do jovem, tal como ele é conduzido na UAMA. Além disso, como há grande demanda de atendimentos pela UAMA que visitei, existe uma lista de espera de adolescentes que já deveriam estar cumprindo a medida, mas que por excesso de trabalho dos técnicos precisa esperar surgir uma "vaga" para que se dê início aos atendimentos e, logo, ao cumprimento da medida.

Outro aspecto que investiguei diz respeito ao tipo de equipamento para o qual são encaminhados os adolescentes que devem cumprir medidas socioeducativas. De acordo com orientações presentes no sítio eletrônico do MDS e na Tipificação Nacional dos Serviços Socioassistenciais, que ordena a oferta desse tipo de serviço no Brasil, o chamado Serviço de Proteção Social a Adolescentes em Cumprimento de Medida Socioeducativa de Liberdade Assistida e de Prestação de Serviços à Comunidade tem como objetivo a oferta de atenção socioassistencial e acompanhamento a adolescentes e jovens em cumprimento de medidas socioeducativas em meio aberto, determinadas judicialmente e deve ser ofertado obrigatoriamente no Centro de Referência

\footnotetext{
10 Disponível em: http://www.sdh.gov.br/assuntos/criancas-e-adolescentes/programas/sistema-nacionalde-medidas-socioeducativas/atendimento-inicial-integrado
} 
Especializada de Assistência Social, o CREAS $^{11}$ (Portal do Ministério do Desenvolvimento Social e Combate à Fome). É dito ainda que esse serviço deve contribuir para o acesso a direitos e para a ressignificação de valores na vida pessoal e social dos adolescentes e jovens e que, para a oferta do serviço, é necessário que sejam observados os critérios de responsabilização de adolescentes e jovens diante da infração cometida. A minha primeira surpresa ao adentrar o campo em questão foi que, no Distrito Federal, esse serviço é executado pelas Unidades de Atendimento em Meio Aberto, as chamadas UAMAs. Passemos então à narrativa de minha entrada em campo e à descrição dos profisssionais da UAMA que visitei.

\footnotetext{
${ }^{11}$ Disponível em:

http://www.mds.gov.br/assistenciasocial/protecaoespecial/mediacomplexidade/adolescentes-emcumprimento-de-medida e http://www.mds.gov.br/assistenciasocial/secretaria-nacional-de-assistenciasocial-snas/cadernos/tipificacao-nacional-de-servicos-socioassistenciais/tipificacao-nacional-de-servicossocioassistenciais
} 


\section{CAPÍTULO 2 - ENTRADA EM CAMPO: A UNIDADE, OS PROFISSIONAIS E OS "MENINOS"}

O presente capítulo irá descrever como cheguei até a UAMA onde desenvolvi a pesquisa, citando o percurso realizado, a apresentação do espaço físico da Unidade visitada e dos profissionais entrevistados, bem como de seu cotidiano de trabalho e o perfil dos meninos atendidos na Unidade, além de alguns números sobre as medidas socioeducativas no Brasil, que permitirão melhor situar o leitor sobre o campo pesquisado.

\subsection{ENTRANDO EM CAMPO}

Tendo conhecimento da política de assistência social em razão do trabalho que desenvolvo no cargo de Analista Técnica de Políticas Sociais no Ministério do Desenvolvimento Social e Combate à Fome, busquei o Centro de Referência Especializado de Assistência Social (CREAS) mais próximo à minha casa no intuito de fazer a primeira abordagem aos profissionais envolvidos com o serviço de proteção social a adolescentes em cumprimento de liberdade assistida e prestação de serviços à comunidade, LA e PSC, como são conhecidas. Essas medidas integram as chamadas medidas socioeducativas (MSE) em meio aberto que, diferente do que eu imaginava, no DF, não são desenvolvidas nos CREAS, mas sim em Unidades de Atendimento em Meio Aberto, as UAMAs, pensadas exclusivamente para atender esses adolescentes que cometeram atos infracionais e que estão cumprindo as MSE de LA e PSC.

$\mathrm{Na}$ semana anterior à minha ida ao CREAS, eu havia feito uma ligação ao equipamento para me certificar de que o serviço era de fato ofertado no local, ao que recebi a resposta positiva. Entretanto, foi apenas ao comparecer ao CREAS que soube que de fato a equipe responsável pelos "atendimentos" aos jovens havia mudado daquele espaço físico havia cerca de duas semanas. No CREAS, indicaram-me o novo endereço da equipe do socioeducativo. Devido à sua recente mudança, a equipe ainda estava se instalando no novo ambiente e não pôde me receber para que eu conduzisse a pesquisa, uma vez que não havia ainda reiniciado os atendimentos aos jovens e estava empenhada em montar o espaço físico. As duas profissionais que me receberam nessa 
unidade indicaram-me uma outra unidade, mais afastada, aonde, enfim, pude começar a desenvolver a pesquisa.

As duas profissionais me passaram ainda os telefones de pessoas da Secretaria de Estado da Criança, em especial da Subsecretaria do Sistema Socioeducativo e da Coordenação do Meio Aberto, a qual essas unidades de atendimento aos jovens se vinculam, que poderiam me orientar acerca da autorização para a minha pesquisa. Ao entrar em contato com essas pessoas, fui informada de que seria necessário contatar a Vara de Execução de Medidas Socioeducativas, vinculada ao Tribunal de Justiça do Distrito Federal e Territórios (TJDFT). Assim o fiz e rapidamente obtive a autorização para entrevistar profissionais, adolescentes e para acompanhar os atendimentos prestados a eles, com a anuência de seus responsáveis legais.

Ao preencher o modelo de solicitação para realizar pesquisa na unidade, reparei que os modelos propostos no sítio eletrônico da Vara de Execução de Medidas em Meio Aberto não se adequavam ao tipo de pesquisa que comumente se faz em antropologia. Isso porque as orientações aos estudantes previam três casos: acesso a processos para coletar dados; agendamento de entrevistas; e para o caso de uma visita pontual à unidade. Como o meu intuito era o de realizar uma observação participante, optei pelo último modelo de solicitação, contudo, sem inserir uma data específica da visita como demandado, inserindo apenas a informação "durante o semestre de 2015", para que ficasse claro que se tratava de visitas "continuadas" e não apenas de uma visita pontual. Além disso, acrescentei ao documento a necessidade de se realizar entrevistas com os profissionais dos equipamentos e meu intuito de assistir aos atendimentos prestados nas unidades.

Anexo ao documento que me autorizava a fazer a pesquisa na Unidade escolhida, vieram orientações sobre como eu deveria conduzir a pesquisa, indicando a necessidade de agendamento de horários com as profissionais e anuência de todos os participantes (profissionais, responsáveis legais e adolescentes). Além disso, uma parte do ECA - Estatuto da Criança e do Adolescente - também foi anexado. Ela frisava a necessidade de que fossem respeitados os artigos do ECA que tratam da preservação da intimidade e da identidade dos adolescentes, como segue:

Art. 17. O direito ao respeito consiste na inviolabilidade da integridade física, psíquica e moral da criança e do adolescente, abrangendo a preservação da imagem, da identidade, da autonomia, dos valores, ideias e crenças, dos espaços e objetos pessoais. 
Art. 143. É vedada a divulgação de atos judiciais, policiais e administrativos que digam respeito a crianças e adolescentes a que se atribua autoria de ato infracional.

Parágrafo único. Qualquer notícia a respeito do fato não poderá identificar a criança ou adolescente, vedando-se fotografia, referência a nome, apelido, filiação, parentesco, residência e, inclusive, iniciais do nome e sobrenome.

Art. 247. Divulgar, total ou parcialmente, sem autorização devida, por qualquer meio de comunicação, nome, ato ou documento de procedimento policial, administrativo ou judicial relativo a criança ou adolescente a que se atribua ato infracional:

Pena - multa de três a vinte salários de referência, aplicando-se o dobro em caso de reincidência.

$\S 1^{\circ}$ Incorre na mesma pena quem exibe, total ou parcialmente, fotografia de criança ou adolescente envolvido em ato infracional, ou qualquer ilustração que lhe diga respeito ou se refira a atos que lhe sejam atribuídos, de forma a permitir sua identificação, direta ou indiretamente.

$\S 2^{\circ} \mathrm{Se} o$ fato for praticado por órgão de imprensa ou emissora de rádio ou televisão, além da pena prevista neste artigo, a autoridade judiciária poderá determinar a apreensão da publicação (BRASIL, 1990).

Pouco depois de duas semanas, já com a autorização da juíza da Vara de Execução de Medidas Socioeducativas (VEMSE) do Distrito Federal em mãos, procurei a unidade indicada pelas profissionais que me receberam na UAMA que estava sendo organizada após a mudança. Cheguei cedo, antes das nove horas e, como de costume, a unidade estava aberta, mas quase ninguém havia chegado. No momento em que cheguei, havia apenas duas profissionais. Uma delas, a pedagoga Isadora ${ }^{12}$, recebeu-me de forma amável e começou a me mostrar o espaço físico da unidade, o que, segundo ela, também devia fazer parte da minha pesquisa. Desculpou-se pelo estado do espaço, explicando-me que em virtude da greve dos trabalhadores responsáveis pela limpeza dos órgãos públicos, o local não se encontrava limpo. A supervisora apenas chegou mais tarde nesse dia e, então, enquanto eu aguardava a sua chegada, conversei com Isadora, e conheci os espaços.

Por volta das dez horas da manhã, a psicóloga Denise me convidou para assistir a um atendimento. Foi a minha primeira experiência com esse tipo de situação. Tratavase do que os profissionais chamam de "acolhimento", em que eles fazem uma "escuta" do adolescente e de sua família, normalmente a mãe, coletando dados pessoais, bem como informações acerca do ocorrido que levou o adolescente a ser apreendido, o que, apesar de já constar nos autos, é uma atitude que segundo as profissionais visa a dar uma chance ao adolescente de "contar a sua versão da história". Outros aspectos são perguntados aos presentes: se o adolescente está matriculado na escola e frequentando

\footnotetext{
${ }^{12}$ Os nomes dos interlocutores são fictícios de modo a preservar suas identidades.
} 
as aulas, se tem alguma dificuldade no ambiente escolar, tanto em termos de aprendizado quanto em termos de relações sociais, bem como na vizinhança (a exemplo de rixas e se sente ameaçado nesses ambientes), se tem algum problema de saúde, qual a composição familiar, como é a sua rotina, se ele trabalha, se ele está envolvido com atividades de lazer, cultura e esporte, se ele já experimentou drogas - lícitas e/ou ilícitas - e se é usuário.

Nesse primeiro "atendimento", a profissional que o conduz procura traçar as "metas do adolescente", o que significa que o profissional que vai acompanhá-lo tem o intuito de fazer com o que o adolescente estabeleça um "compromisso", não só perante aquele técnico que o atende, mas também, de forma mais indireta, ao "juiz". Esse personagem, aliás, é citado constantemente como aquele que vai, ao final dos acompanhamentos, avaliar o cumprimento dessas "metas" e julgar se o adolescente deve ou não ser liberado da medida que lhe foi designada.

A esse respeito, cabe uma diferenciação entre o que se chama "Liberdade Assistida" e "Prestação de Serviços à Comunidade". O primeiro, LA, visa ao acompanhamento por pelo menos seis meses do adolescente e suas primeiras metas se referem à "escolarização" e à "profissionalização" do jovem, isto é, ele deve frequentar a escola e estar inserido em cursos profissionalizantes ou estágios ou, caso já tenha idade, em trabalhos formais, que devem ser comprovados por meio da apresentação da carteira de trabalho aos profissionais da UAMA. Por outro lado, a PSC pode ser cumprida em prazos diferentes, estipulados pelo juiz. Nesses casos, o adolescente é "acolhido" pela UAMA e "encaminhado" para uma entidade conveniada para prestar algum tipo de serviço. Nos dois casos, os profissionais buscam fazer um acompanhamento, mesmo que telefônico, para saber se o adolescente tem cumprido os seus "compromissos".

Foi me relatado que o ideal é que os adolescentes comparecessem a UAMA no mínimo uma vez por semana. Entretanto, devido às grandes demandas que o equipamento recebe, os profissionais, assoberbados de "casos" para tratar, de "atendimentos para realizar", bem como de vários tipos de "relatórios" que lhes são demandados, não conseguem realizar os atendimentos mais do que uma ou duas vezes por mês com cada adolescente acompanhado. As profissionais com quem conversei foram unânimes em dizer que essa dificuldade em se implantar um atendimento mais frequente está ligado ao fato de o serviço hoje ser muito baseado em "dados", como me disse uma delas, isto é, "burocrático", dependente do preenchimento de uma série de 
"relatórios", o que toma grande parte de seu tempo e acaba tirando seu foco do principal: o "atendimento" aos adolescentes e o seu "acompanhamento".

\subsection{A UNIDADE E OS PROFISSIONAIS}

De acordo com informações retiradas do relatório de uma pesquisa conduzida pela Companhia de Planejamento do Distrito Federal - Codeplan ${ }^{13}$-, o Distrito Federal conta com 14 Unidades de Atendimento em Meio Aberto (UAMA), responsáveis pelas medidas de Prestação de Serviços à Comunidade e de Liberdade Assistida, localizadas nas seguintes regiões administrativas: Brazlândia, Ceilândia, Gama, Guará, Núcleo Bandeirante, Paranoá, Planaltina, Plano Piloto, Recanto das Emas, Samambaia, Santa Maria, São Sebastião, Sobradinho e Taguatinga. Para a medida de Semiliberdade, há três casas: em Taguatinga, no Gama e no Recantos das Emas. Há, ainda, cinco Unidades de Internação: Unidade de Internação do Plano Piloto (UIPP), Unidade de Internação de Planaltina (UIP), Unidade de Internação do Recanto das Emas (Unire), Unidade de Internação de São Sebastião (UISS) e Unidade de Atendimento Inicial (UAI). A UISS destina-se à internação provisória, enquanto a UAI conta com diversos serviços para os adolescentes no início do vínculo com o sistema, incluindo o pernoite daqueles que foram apreendidos pela polícia, mas ainda não foram encaminhados a nenhuma unidade.

A UAMA que me foi indicada se localiza em uma região administrativa do Distrito Federal que é considerada pelas profissionais como uma unidade que não se encontra em uma região "tão difícil" do DF. Isto é, pelo que foi me dito, existiriam outras realidades mais complicadas, tanto do ponto de vista socioeconômico quanto do ponto de vista da violência e, logo, do tipo de realidade com a qual os profissionais se deparam quando realizam os atendimentos. Como a primeira unidade que visitei ainda estava se estruturando no momento em que fui até ela e como o tempo para a pesquisa de campo estava correndo, optei por conhecer outra unidade e lá realizar o trabalho de campo, que descreverei agora.

Cabe lembrar que, como me contaram as profissionais, a Unidade não estava em local com as realidades mais duras, mas ainda assim, pela sua abrangência territorial, lidava com adolescentes que tinham condições mais próximas das condições de

\footnotetext{
${ }^{13}$ Falarei dessa pesquisa mais adiante. O relatório eletrônico me foi enviado pelas técnicas da UAMA que visitei.
} 
adolescentes que são atendidos em unidades em locais "mais difíceis". Dessa forma, começou a se delinear para a pesquisadora a divisão entre dois públicos lá atendidos de acordo com a região: os do que podem ser chamados como residentes da região onde está presente o equipamento, que contam com uma realidade socioeconômica mais favorecida, e os que residem numa região próxima, que é atendida pela unidade, mas que possuem uma situação socioeconômica mais desfavorável, o que ficou evidente com a dificuldade, por exemplo, de conseguirem pagar a passagem de ônibus para ir até a unidade ou para cumprirem prestação de serviço à comunidade em outros locais.

Como dito acima, assim que adentrei a UAMA, fui recebida pela pedagoga Isadora, que me mostrou o espaço físico da unidade. Este ocupa uma parte de uma construção destinada a outro equipamento público da assistência, por isso, algumas de suas salas são utilizadas por usuários da assistência social de outros serviços que não o ofertado pela UAMA. Estive na unidade em janeiro, março e junho. Em janeiro, algumas salas estavam fechadas, mas em março e junho elas eram ocupadas por senhoras que faziam alguns trabalhos manuais.

Ao entrar na Unidade, vemos um corredor que abriga quatro salas à esquerda, duas utilizadas pelo outro equipamento e duas pela UAMA, sendo uma delas composta de uma mesa redonda e algumas cadeiras e utilizada para atendimento com adolescente e família, e uma menor, composta de uma mesa pequena e apenas duas cadeiras, que, conforme me disseram, é mais utilizada para o atendimento individual; dois banheiros à direita, um masculino e um feminino, cujas portas costumam ficar trancadas como forma de garantir o seu uso apenas pelos profissionais da UAMA, que guardam suas chaves; uma cozinha à direita e em seguida a sala da coordenadora da unidade; ao final do corredor avista-se uma sala maior, onde trabalham todos os profissionais da unidade, e que é composta por mesas, computadores, telefones e arquivos. Essa sala maior dá acesso ainda a uma outra sala menor, num dos cantos da sala maior, próximo aos arquivos, que contém uma espécie de despensa, local que não acessei.

Ao fundo e à esquerda senta-se o técnico administrativo, que apoia o trabalho dos demais profissionais. Em janeiro, esse cargo era ocupado por Eduarda que, no entanto, saiu de licença, vindo este cargo a ser ocupado por Gabriel. Na UAMA, há dois pedagogos, Isadora e Marcelo, duas psicólogas, Denise e Clarice (que em junho saiu da UAMA e foi para uma unidade de internação) e uma assistente social, Aline. Além desses profissionais, existem também 2 ATRS, Rebeca, Henrique e Ricardo, e a 
supervisora da unidade, que em janeiro era Letícia e que, a partir de março era Regina ${ }^{14}$, devido às trocas de gestão decorridas da mudança de governo no DF. Os ATRS, Atendentes de Reintegração Social (ATRS), têm por função acompanhar os profissionais pedagogos, psicólogos e assistentes sociais nos atendimentos e apoiá-los no que diz respeito ao acompanhamento dos adolescentes. Os profissionais dizem que atualmente estão com muitas demandas, de modo que cada profissional responsabilizase pelo atendimento de mais de 20 adolescentes por mês (por mês, geralmente, ou então duas vezes por mês), acompanha-os no cumprimento de sua MSE por meio, por exemplo, de ligações telefônicas e envio de telegramas, e redigir relatórios relativos a cada adolescente.

De acordo com levantamento interno do mês de maio da Unidade que visitei, há 107 meninos "efetivos", isto é, sendo acompanhados pelos profissionais, e outros 155 "não efetivos", isto é, que ainda não são acompanhados, por não terem sido localizados pelos profissionais ou por estarem aguardando vaga. Dos adolescentes efetivos na Unidade no mês de maio, 58 cumpriam LA, 41, LA e PSC e 8, PSC.

Como estratégia de pesquisa, sempre que eu podia dispor de um tempo mais prolongado com as profissionais, eu realizava entrevistas, em que buscava conhecer suas trajetórias, de vida e de trabalho, em especial na assistência social, sua formação acadêmica, motivações para o trabalho no Sistema Socioeducativo, bem como suas percepções sobre seu papel no equipamento e sobre os limites e possibilidades de sua atuação na unidade e no que se refere à vida dos adolescentes, abarcando o objetivo do trabalho realizado, os entendimentos sobre sua prática, interessando-me, entre outras coisas, explorar a noção de "mudança de vida" referente aos adolescentes e os principais termos e categorias acessados pelos profissionais e em torno dos quais organizam a sua atuação.

No âmbito deste capítulo, tratarei apenas dos primeiros tópicos, referentes à caracterização dos profissionais, personagens-chave para a compreensão que viso a traçar nessa dissertação. Em virtude do tempo disponível e dos objetivos da pesquisa, priorizei as entrevistas com os chamados "educadores sociais", a saber, os técnicos pedagogos, psicólogos e assistentes sociais que realizam os atendimentos, organizam as oficinas coletivas e que têm um contato mais próximo com os adolescentes, além, claro, das duas supervisoras da unidade. Priorizei a profundidade das conversas, portanto, em

\footnotetext{
${ }^{14}$ Os nomes dos profissionais são pseudônimos para preservar a sua identidade.
} 
detrimento do número de entrevistas, que chegavam a durar horas. Cabe lembrar, contudo, que as conversas informais com as técnicas, a presença nas oficinas e momentos em que atuei mais como "espectadora" do cotidiano da unidade também renderam bastante para a coleta de dados e compreensão da realidade etnográfica da UAMA visitada.

A primeira profissional com quem tive a oportunidade de conversar mais tranquilamente foi com a psicóloga Denise. No início da entrevista, percebi a sua vontade em falar-me do cotidiano da unidade e dos problemas do "sistema" das MSE. Isso veio a acontecer com todas as demais entrevistas, isto é, os entrevistados se sentiram à vontade para se manifestarem sobre dimensões diversas do seu trabalho, antes mesmo que eu os indagasse a esse respeito. Eu dispunha de uma série de tópicos que pretendia que fossem abordados, mas geralmente a entrevista começava com temas trazidos à tona pelos próprios entrevistados. Denise, por exemplo, iniciou a nossa conversa contando-me que os profissionais não atuavam "multiprofissionalmente", como ela entende que deveria ser feito, isto é, que a equipe de "socioeducadores", que deve ser composta por pedagogos, assistentes sociais e psicólogos, atuavam, na prática, de maneira fragmentada, ou seja, cada profissional conduzia o "atendimento" de um "menino" sozinho/a. Assim, cada "atendimento" seria feito de forma diferente, a depender da formação da pessoa responsável por ele, uma vez que a formação acadêmica é que determinaria o foco do "atendimento". Mais uma vez, a inadequação dessa forma de trabalho se daria por causa da demanda elevada, em suas palavras, por receberem "muitos meninos" e, logo, por terem que realizar muitos "atendimentos", de modo que não seria possível que todos os profissionais atendessem todos os "meninos acompanhados" pela Unidade. Segundo ela, o número de "meninos" por profissional já teria excedido o máximo estipulado de vinte.

A respeito da sua função na Unidade, ela me esclarece que enquanto profissional da psicologia ela não faz terapia, mas sim encaminha quem precisa para o CAPS Centro de Atenção Psicossocial ${ }^{15}$. Desde que comecei a frequentar a unidade, o discurso

\footnotetext{
${ }^{15}$ Conforme consta no sítio eletrônico do Ministério da Saúde, os CAPS são "instituições destinadas a acolher os pacientes com transtornos mentais, estimular sua integração social e familiar, apoiá-los em suas iniciativas de busca da autonomia, oferecer-lhes atendimento médico e psicológico. Sua característica principal é buscar integrá-los a um ambiente social e cultural concreto, designado como seu território, o espaço da cidade onde se desenvolve a vida quotidiana de usuários e familiares". Em muitas situações, os adolescentes atendidos na UAMA são encaminhados para os chamados CAPS AD, que devem funcionar 24 horas e são especializados para usuários de drogas e álcool. Disponível em http://portalsaude.saude.gov.br/index.php/cidadao/acoes-e-programas/conte-com-a-gente/leia-mais-contecom-a-agente, acesso em 02 de maio de 2015.
} 
das profissionais repete um pouco o discurso dessa primeira profissional entrevistada, o de que o cerne de seu trabalho na unidade se baseia em fazer "encaminhamentos", tanto para a saúde, como para cursos ou para outros equipamentos da assistência social, como os CRAS, e para o Conselho Tutelar. Denise me contou que a maior parte dos adolescentes não aceita os encaminhamentos para a saúde. No que diz respeito ao CAPS, por exemplo, os adolescentes o entendem como "coisa para louco" e então têm resistência a procurá-lo. No que tange ao tratamento para dependentes químicos, situação frequente entre os adolescentes atendidos, também há uma resistência. Quando chegam a buscar o tratamento, eles faltam ou, nas palavras de Denise, "não aderem de fato a ele".

Após essa fala acerca do seu trabalho na unidade e das dificuldades que ela percebe, comecei a perguntar a respeito de sua trajetória. Conforme me contou, trabalha com a assistência social desde 2006, mas não por escolha e sim pela oportunidade que teve quando da abertura de uma vaga. Ela nem mesmo sabia o que era o serviço que viria a prestar quando se candidatou para a vaga. Três anos depois, prestou um concurso para continuar trabalhando na assistência social, haja vista que antes estava na condição de "contratada". Denise foi uma das profissionais que mais demonstrou desmotivação para desenvolver o trabalho como educadora social. Nas palavras dela, esse é "frustrante", "não funciona", em especial porque o adolescente comete um ato infracional e demora para ter a "punição". Nesse momento, nossa conversa é interrompida pela chegada do adolescente e de sua mãe para um acolhimento, que seria a minha primeira experiência de observação de um atendimento, que pretendo descrever mais adiante.

Após a finalização deste atendimento, continuo minha conversa com Denise, agora de modo mais informal e menos estruturado. Ela volta a falar sobre a sua frustração com o trabalho. Ela diz que apesar de hoje o processo estar mais rápido, o jovem vai à UAMA e "não faz as coisas". Ela se remete a uma das principais frases ditas pelos adolescentes atendidos, a de que a medida "não dá em nada". Denise diz não ver "efetividade" no trabalho que faz, principalmente porque a "rede" não funciona, isto é, os demais serviços públicos que deveriam atende-los não funcionam como deveriam, e também porque os adolescentes não comparecem aos atendimentos, fato, aliás, que em pouco tempo de campo eu pude observar. É muito comum que os "meninos" faltem aos atendimentos. Diversas vezes ouvi das profissionais: "ah, o atendimento está marcado, se você quiser vir para ver, mas não sei se ele virá"; ou então: "está agendado, mas acho 
que ele não vem não". Ter agendado um atendimento comumente não significa, portanto, que haverá atendimento.

Uma forma de mobilizar os adolescentes para que cumpram a medida e para minimizar a sensação de que ela não traz "consequências" para a vida do jovem, o que seria negativo para o atingimento das metas do serviço, é se referir ao risco da aparição da polícia que, nas palavras de Denise, serve para "pôr um medinho" neles para ver se assim evitam o descumprimento da medida. Costumam alertar que se o adolescente for apreendido, a polícia logo verá que ele está "em medida" e isso será um problema para ele. Ainda aguardando a supervisora da unidade me receber para uma conversa em sua sala, continuo ouvindo Denise.

A psicóloga se mostra muito frustrada com o trabalho também porque, novamente, o não cumprimento das medidas não acarretaria em "consequências" para os adolescentes, especialmente porque, segundo ela, tem sido muito comum o encaminhamento por "remissão" (ver capítulo 1). Explicou-me que quando um adolescente parece envolvido em um ato infracional, mas não se tem provas suficientes para sentenciá-lo e não se tem uma confissão, aplica-se a "remissão", que, no seu entendimento, seria uma espécie de perdão do Estado, que, entretanto, resulta na aplicação de uma medida socioeducativa ao adolescente. Isso seria, de acordo com ela, um contrassenso, pois se o Estado perdoa o adolescente, esse não deveria receber nenhum tipo de medida ou de "punição". Ocorre que, conforme me contou, tendo em vista que não se sabe ao certo sobre o envolvimento do adolescente naquele ato do qual ele fora inicialmente acusado, ele não seria, diferente de casos em que se tem um flagrante, por exemplo, "obrigado a cumprir a medida", o que implica que o seu descumprimento não ocasionaria nenhum tipo de sanção.

De acordo com ela, os adolescentes não sabem, nos termos da lei, que podem “descumprir" as medidas, mas que a sua própria experiência com o descumprimento e a experiência de amigos lhes mostram que isso é possível e que não existe nenhuma "consequência" em virtude desse descumprimento. Esse fato, e o alto número de encaminhamentos por "remissão", parece frustrar ainda mais a profissional, que afirma que para esses casos não há o que fazer se o adolescente não cumprir a medida, o que remete a uma sensação de desempoderamento dos profissionais. A fala de Denise também foi permeada por explicações sobre o processo de encaminhamento dos meninos, desde a sua apreensão, até a sua chegada à UAMA. 
Quando a supervisora dispôs de tempo para conversar comigo, chamou-me no cômodo em que eu aguardava por ela sentada em uma das três cadeiras acolchoadas do recinto e onde conversava com Denise. A supervisora, Letícia, conduziu-me até a sua sala, sentou-se em uma cadeira por trás de uma escrivaninha e disse-me para sentar também, do outro lado da mesa. Sentei-me e antes que eu começasse a fazer perguntas, ela começou a falar da mudança da gestão em virtude da troca de governador do DF e como isso havia deixado as coisas incertas dentro da unidade. A sua própria permanência no cargo de supervisora da unidade era algo ainda não sabido. Mencionou que a secretária da Secretaria da Criança, secretaria a qual estão vinculados, também mudou. Novamente, senti-me conduzida pela minha entrevistada: antes que eu expusesse meus questionamentos a Letícia, ela começou a falar-me de assuntos diversos, como a carreira do sistema socioeducativo no DF, do organograma da Secretaria da Criança, da "filla de espera" de meninos para serem atendidos na Unidade, da dificuldade das famílias para se deslocarem até a UAMA, do aumento da "reiteração no ato infracional", dos locais de cumprimento da PSC e, finalmente, cita a frase que eu acabara de ouvir de Denise, a de que os adolescentes acham que a medida cumprida na UAMA "não dá em nada".

Essa expressão foi dita por todas as profissionais que entrevistei e com quem conversei. Por essa expressão, elas entendem que as medidas socioeducativas não significam "nada" para os adolescentes, uma vez que eles entendem que o seu descumprimento não acarretará em consequências mais drásticas para suas vidas. Algumas profissionais durante os atendimentos tentam frisar que as medidas "dão sim em alguma coisa" ao dizerem para eles: "como assim não dá em nada? Você está aqui, não está?”. Essa frase dita pelas profissionais visa mostrar aos adolescentes que o fato de terem "pego uma medida" resultou sim em alguma coisa, afinal, eles já teriam se mobilizado para irem até a Unidade. Nesse momento, percebi a necessidade de me atentar para os discursos das expectativas e da motivação dos profissionais, que poderiam me ajudar a compreender como concebiam o seu trabalho com os adolescentes e o que as norteava em suas atitudes cotidianas para conferir sentido ao seu trabalho.

No dia seguinte, quando eu tentava novamente estabelecer um diálogo mais estruturado com a supervisora Letícia, investiguei a sua trajetória. Diferentemente do restante dos profissionais, ela viera de uma realidade socioeconômica mais humilde, e do que ela chamou de uma "trajetória de vida beneficiada pelas políticas sociais". 
Letícia usufruiu da chamada "Bolsa Escola", de recursos do Prouni e participou do "Agente Jovem"16. Assim, como numa espécie de lógica da dádiva, ela sente que deve retribuir à sociedade e essa é uma das razões por trabalhar na assistência social. Conforme me contou, Letícia sempre gostou da assistência social e foi assistida por ela, considerando a sua trajetória uma prova de que as coisas de fato funcionavam - e funcionaram para ela -, o que, como pontua, é desconhecido por muitos em virtude do que ela chamou de "cultura da mídia", que não veicula esse tipo de informação. Grávida de seu segundo filho no momento em que a conheci, Letícia me disse que a estrutura familiar e socioeconômica dos adolescentes atendidos pela UAMA lembra muito a sua própria e, conforme me contou, difere dos demais membros da equipe socioeducativa da UAMA: "família humilde, mãe solteira e pai alcóolatra". Dessa forma, Letícia entende que ela é uma "servidora do sistema" e que se o sistema precisar dela em outro espaço que não o da UAMA, ela tem que ir.

A supervisora, que é pedagoga de formação, também é concursada da carreira do sistema socioeducativo do DF, assim como os demais, e disse que quer continuar trabalhando com a assistência social e se especializar para "continuar contribuindo para esses jovens", pois, em suas palavras, "deve contribuir de forma maior para a sociedade. Letícia disse que tem "gratidão com o social e que pode contribuir com ele". A sua frustração é ver que muitas vezes a "equipe faz de tudo, mas de repente recebe um contato da família dizendo que o 'menino' foi assassinado ou que contraiu uma doença grave" ou mesmo se frustra quando o jovem simplesmente abandona o acompanhamento ou reincide quando se achava que "tudo ia bem". É nesses momentos, afirma Letícia, que "a gente pensa 'o que eu poderia ter feito?", "a gente se envolve muito com a família", diz. Mas há também o lado bom do trabalho, que é, para Letícia, quando se vê que o menino está inserido no trabalho e que está estudando, "cumprindo as suas metas". Nas palavras dela, há de se calibrar as expectativas à realidade que se apresenta à UAMA:

Se atendo trinta e um melhora, está bom dentro desse contexto. A gente tem que saber o que é esse "regenerar" que nos perguntam. O jovem já está fora dos padrões da sociedade, quer que ele se enquadre, mas talvez ele nunca se

\footnotetext{
${ }^{16}$ Projeto co-financiado pelo Governo Federal que foi substituído pelo "Pro-Jovem". Nesse tipo de programa, é oferecida uma bolsa ao adolescente e atividades de capacitação. Outro programa muito citado pelos interlocutores, em especial pelos pais dos adolescentes atendidos, é o programa "Jovem Candango", do Distrito Federal, que atende a população "em risco social" que tem de 14 a 18 anos, por meio da promoção de formação técnico-profissional. Para mais detalhes, ver http://jovemcandango.org.br/\#, acesso em 16 de julho de 2015.
} 
enquadre, por sua história e formação cultural, por isso trabalhamos dentro desse contexto.

O salário e as condições de trabalho são um fator que a desmotiva. Ela menciona o episódio em que um policial a diz que os profissionais do sistema socioeducativo "passam a mão na cabeça dos meninos" e a indaga por que, ao invés de estarem cumprindo medidas, os meninos não estão presos. Para ela, essa visão é fruto de uma curiosidade, de um preconceito e de uma "taxação da mídia". "O que poderia ser feito de fato para mudar essa situação?”, indaga o policial à Letícia, que o responde que a carga horária de trabalho da população toda deveria ser menor, para que os pais tivessem mais tempo para seus filhos e que estes deveriam estudar em escolas de tempo integral para não ficarem "ociosos na rua".

Para Letícia, os jovens "infracionam" por conta de sua condição de vida de "ser humano", em que "falta acompanhamento familiar" e "estrutura psíquica para fazer a "boa opção"'. Letícia fala que há mais razões para estar desmotivada do que motivada para o trabalho que realiza, mas que, ainda assim, "acredita no sistema" e que ele já melhorou muito, mencionando, a esse respeito, a construção de novas unidades de internação e o aumento do número de funcionários efetivos, concursados, do sistema socioeducativo no DF. Assim como Denise, ela menciona os limites de sua atenção: encaminhamentos para saúde e educação são entraves, faltam políticas para egressos do sistema socioeducativo, há o problema da "incompletude institucional" ou, nas palavras de Denise, da "rede" que não funciona.

Finalizamos a nossa conversa com algumas considerações mais "materiais" do trabalho que desenvolve: ela me mostra um prontuário de atendimento, uma ficha preenchida após um acolhimento, uma guia de execução e alguns autos. Por fim, menciona que os adolescentes que trabalham de "carteira assinada" têm a medida de Prestação de Serviços à Comunidade convertida em cestas básicas, pois é comum o entendimento do judiciário de que o jovem já está cumprindo uma das metas - a da inserção em atividade profissional. No entanto, como observa, as profissionais frisam junto à família, conscientizando-a, de que o valor das cestas deve sair do salário do adolescente de modo que ele sinta que o que ele fez trouxe uma "consequência" para ele, porque, conforme Letícia, "se sair dos pais, não se tem essa dimensão da tomada de 'responsabilidade' da parte do adolescente". 
A terceira profissional que entrevistei foi a psicóloga Clarice. No momento em que conversamos, em janeiro, ela estava na UAMA há apenas um mês e, com relação ao seu trabalho na Unidade como educadora social, disse-me "fazer o que acha que tem que fazer", pois só havia assistido a um atendimento até aquele momento. Clarice, assim como os demais, também pertence à carreira do sistema socioeducativo e assim como Denise passou no concurso sem conhecer muito a área. Ela se formou e já ingressou na carreira.

Clarice afirmou ter tomado conhecimento do que se tratava o trabalho na área apenas no último semestre de 2014, aprendendo na prática como fazê-lo. Antes de ir para a UAMA, ela trabalhou em uma unidade de internação, mas lá, contou-me, "as coisas eram difíceis, tanto o público quanto o trabalho", mas ainda assim ela sentia que parecia fazer "algo relevante". Segundo ela, a "energia e o público eram pesados" e as histórias que os profissionais vivem nesses ambientes são o que mais os adoecem, pois eles entram em contato com "muita coisa ruim". Aos educadores sociais, explica-me, é demandado "consertar o jovem" que "está estragado", mas tal como Clarice compreende, não é o jovem que está estragado e os motivos que o fazem cometer atos e reincidir não estão na governabilidade dos profissionais e isso faz com que a profissão do educador social esteja cercada por frustrações.

A motivação para trabalhar com esses jovens, diz Clarice, reside da sensação de que "está fazendo alguma coisa". Ela entra em contato com o jovem, vê que ele precisa escutar, ela tenta fazer com que "ele pense" e, nesse sentido, o profissional se torna "importante para as pessoas que atende", "se não agora, no futuro" ele o será. Mais uma vez, ela me diz que “as pessoas querem que os profissionais 'mudem o jovem', mas essa escolha é dele", assim, "os profissionais não podem se responsabilizar pelas escolhas dos outros [dos jovens], mas podem ajudá-los a "pensar sobre o percurso de suas vidas"” e de que eles "são mais do que ato que cometeram". Comentou que a medida não funciona porque se quer "colocar um bandaid numa pessoa que está numa UTI", isto é, os "meninos" precisariam de muito mais, só as medidas "não dão conta". Entre o que falta ela menciona uma "orientação para os pais sobre o que é ser pai, um bom atendimento de saúde", citando a falta de diagnóstico de TDAH, que é uma barreira ao desenvolvimento escolar de muitos deles. Além disso, segundo ela, os professores têm medo dos "meninos em medida", porque a sociedade "está violenta mesmo" e "os meninos não têm limite" e citou o despreparo de uma escola que não está pronta para trabalhar com o aluno diferente e com o aluno "real", operando sempre a partir do 
"aluno ideal". Ela entende o seu trabalho como psicóloga na Unidade no que diz respeito à "escuta de famílias e de jovens". Segundo ela, eles são muito pouco ouvidos.

Conforme me contou, Clarice procura também fazer um trabalho de "responsabilização" com os adolescentes, isto é, de "responsabilizá-los pelo estigma que eles têm”, lembrando que a família e a escola não confiam no jovem porque eles deram motivo para a criação do estigma que os cerca, mas que, ao mesmo tempo, no momento em que estão na UAMA e cumprindo as medidas, eles têm a oportunidade de reconquistar essa confiança. Ela faz alusão também à adolescência como um momento da vida em que o jovem quer conhecer o mundo exterior e a família o prende. Sobre as possibilidades do êxito das medidas e da consequente transformação da trajetória dos jovens atendidos, Clarice comenta que falta uma "ligação com a rede", em especial com a da comunidade, e da "disponibilidade" dos jovens, pois muitas vezes a profissionais se mostra presente para os adolescentes, mas eles "não estão tão disponíveis".

No acolhimento, contou-me, muitas vezes a presença da família do jovem o inibe e a confiança dele nos profissionais vai sendo construída aos poucos, durante os próximos atendimentos. Há diferentes perfis de jovens, segundo Clarice: "alguns parecem vir porque querem mudar, e outros que parecem que vieram porque a mãe trouxe". Novamente, tem-se o discurso de que a medida "não dá em nada". Segundo Clarice, os adolescentes veem as medidas (ela citou em especial a Liberdade Assistida LA) como "insignificante": "não dá em nada", "nunca vai acontecer comigo, não vão me pegar mesmo nunca", nas palavras deles citadas por Clarice. Para a psicóloga, essa falas aludem a uma ideia de que o descumprimento da medida não traz "consequências" aos jovens: na UAMA, diz Clarice, não é tão "delimitado" quanto na internação, "se eles não quiserem vir, eles não vêm".

Em sua compreensão, os adolescentes não veem a LA como "punição suficiente" para ser considerada por eles em certos momentos, como, por exemplo, no momento de decidir pelo cometimento de um ato infracional. Isto é, os adolescentes não deixariam de roubar, por exemplo, porque iriam "pegar uma LA" como consequência de seu ato. Mas a própria ideia da LA, como compreendido pela profissional, não é de fato a de uma "punição", mas sim de um papel de inserção do jovem na Rede, isto é, de ajudar o jovem a acessar serviços públicos, a estar matriculado e frequentando a escola e inserido em cursos ou estágios e empregos. Inclusive, menciona ela, há diversos estudos que mostram que a evasão escolar é "um fator de risco para o ato infracional e que maior escolaridade facilita menor envolvimento em atos": ocupa-se o tempo do 
menino, ele está na escola e não na rua. Para além desse dado, o foco na escolarização dos meninos vêm da própria obrigação do Estado de "fornecer a escola", isto é, remetendo a uma noção da legislação em que o acesso à educação deve ser universal e garantido pelo Estado ${ }^{17}$. Entretanto, ela finaliza sua fala questionando se "a escola como está hoje ajuda”. A lei - o ECA - é boa, porque é embasada, segundo ela, muito "utópica", mas na prática "não ocorre assim, se ocorresse, os jovens não estariam assim [como estão hoje]". Para ela, o maior êxito de seu trabalho é "perceber que o jovem tem plena consciência do que ele fez e de como isso afeta ele e as pessoas próximas e a partir dessa ampliação de consciência, fazer suas próprias escolhas". Nessa frase de Clarice reside a ideia de uma "responsabilização", que será tratada mais adiante.

Em janeiro, além das entrevistas com as profissionais que mencionei acima, tive a oportunidade de observar dois atendimentos e dois momentos de uma palestra, espécie de oficina, proferida a adolescentes e seus responsáveis legais por Rafael, um "exsocioeducando", jovem de 23 anos que passou pelo sistema socioeducativo e "alterou a sua trajetória de vida". Esse evento será descrito no capítulo seguinte.

Voltando à UAMA, já no início de março, sou informada de que a supervisora Letícia saíra, como ela mesma, no final de janeiro, já havia me comunicado que aconteceria. Letícia havia pedido transferência para uma unidade de internação e a esse respeito disse que a nova realidade de trabalho seria um desafio para ela, pois nunca havia trabalhado na internação, mas que seria melhor para ela em virtude da proximidade do novo local de trabalho com a sua casa. Perguntei o que ela ia fazer lá e ela me contou que o mesmo que já fazia na UAMA: dar atendimentos aos adolescentes, mas que, nessa nova situação, estariam internados. Sem que eu perguntasse, ela exibiu uma expressão de frustração e disse:

é, são atendimentos, mas lá vai ser um pouco diferente, porque eles estão internados. É complicado, porque eu vou embora para casa todo dia e eu sei que eles vão ficar lá ainda um ano, um ano e meio internados. Nesse tempo a minha vida vai ter mudado tanto e a deles vai continuar a mesma coisa, eles vão continuar lá...

Nesse momento, a psicóloga Clarice, que parecia carregar algumas fichas de atendimento para o arquivo da sala, diz: “é, vão ficar lá por escolha deles!”. Essa frase me fez lembrar a entrevista que eu havia feito com ela na semana anterior, em que ela

\footnotetext{
${ }^{17}$ A esse respeito, consultar o artigo 205 da Constituição Federal de 1988, Capítulo III, Seção I, que estabelece a educação como direito de todos e dever do Estado e da família.
} 
citava a limitação do profissional frente às escolhas dos adolescentes, o que me pareceu uma alusão a um certo nível de responsabilização pessoal dos adolescentes por seus atos maior do que eu pude perceber na fala de outras profissionais e mesmo da supervisora da Unidade. Assim, foi possível captar uma nítida distinção da forma como operavam as duas profissionais no que tange à situação vivida pelos adolescentes.

Clarice enfatizava muito "as escolhas pessoais" dos adolescentes, entendendo o seu papel como limitado a orientações a eles e ao que ela chamou de "ampliação de consciência para que eles pudessem fazer escolhas", ao passo que Letícia tinha falas ligadas a um sentimento de "impotência", do tipo, se o adolescente "não melhorou", o que a gente podia ter feito?, que trazia para si uma sensação de frustração maior, em certo sentido, do que a psicóloga Clarice, cuja forma de pensar os limites e possibilidades de sua atuação profissional se pautava numa lógica mais individualista e num sujeito "livre para fazer as suas próprias escolhas" e que, nesse sentido, não se pode controlar ou obrigar a fazer nada, mas trabalhar no nível de uma "consciência" que o possibilite uma reflexão sobre sua trajetória de vida e, posteriormente, a sua alteração, passando a fazer "boas escolhas de vida".

A supervisora Letícia, entretanto, colocava-se numa posição de se cobrar mais pelas trajetórias que não foram alteradas, o que, parece-me, coincide com a sua vontade de retribuir para esses jovens um pouco do que ela ganhou das políticas sociais em sua própria trajetória, se ela tinha uma realidade socioeconômica e uma estrutura familiar próximas as deles e as políticas a atingiram de forma tão positiva, por que isso não ocorre com eles também?

Com a saída de Letícia, precisei me apresentar à nova supervisora que passou a ocupar o seu lugar na unidade: Regina. Assim como Letícia, Regina se mostrou muito aberta para me receber e foi muito amável, tendo me informado, inclusive, que em uma reunião de equipe poucos dias antes da minha chegada, os profissionais já haviam discutido a minha presença na unidade. No início de minha conversa com Regina, ela já menciona que na semana seguinte seria conduzida na unidade um "grupo de pais", uma espécie de oficina para trabalhar com eles o que seriam as MSE, bem como "ilusões e expectativas" acerca do que os profissionais podem fazer pelos filhos deles e o que têm que ser feitos pelos próprios responsáveis dos jovens. Segundo ela, muitos pais se veem enfraquecidos no que tange a impor "limites" aos seus filhos e acabam "delegando" muitas responsabilidades aos profissionais da Unidade e depositando muitas expectativas quanto ao que eles podem fazer para transformar os seus filhos. 
Assim, o objetivo da oficina seria o de esclarecer para os pais os termos do que Regina chamou de "parceria profissionais e pais". Esse encontro seria o primeiro de muitos que Regina disse que gostaria que acontecessem na UAMA. Esse primeiro seria um momento para ela conhecer um pouco as famílias atendidas na unidade, uma vez que ela acabara de chegar ao local após a saída de Letícia. Mencionou ainda que ela teria que se ausentar alguns dias da unidade, por estar participando de um grupo de discussão do Plano Decenal para as MSE do DF que envolve, por exemplo, a construção de uma metodologia para pais e adolescentes. Regina me contou que é psicóloga de formação e também concursada do sistema socioeducativo, tendo já trabalhado em outra UAMA antes de vir como supervisora para a unidade que eu pesquisava. Ela pontua diferenças entre a unidade de onde veio e essa que está atualmente lotada: "aqui os atos infracionais são mais leves e a condição econômica dos adolescentes é um pouco melhor que na outra onde eu estava", apesar de esta UAMA também atender adolescentes de uma região administrativa pouco favorecida do DF.

Regina me contou que a sua trajetória de trabalho iniciou na saúde, quando trabalhou no Hospital Sarah Kubitscheck, e que a sua trajetória na assistência social começou quando trabalhou em um abrigo para crianças e adolescentes com paralisia. Em 2010, ela foi aprovada no concurso para trabalhar no Sistema Socioeducativo que, à época, estava vinculado à Secretaria de Justiça do DF e não à Secretaria de Estado da Criança, como é hoje. Ela disse "acreditar mesmo" nas medidas em meio aberto e queria trabalhar com elas por entender que são medidas mais "profiláticas" em que "a liberdade ainda está preservada" e, portanto, haveria uma "capacidade maior de intervenção no meio aberto". Orienta a sua atuação a ideia de implementar uma "proposta de intervenção que possa gerar transformação do adolescente, de suas famílias e impactar também a comunidade".

A sua estratégia para atingir essa meta começa por "fazer vínculo com adolescente", passar curtas e filmes, levá-los a exposições e passeios para "retirá-los um pouco da realidade já conhecida, oferecendo um 'abrir do olhar'”. Em oficinas com os adolescentes, a supervisora disse ser importante tratar de temas como violência, justiça com as próprias mãos, gênero (especialmente para trabalhar a responsabilização dos meninos em casa), e a legalização da maconha, entre outros. Com os pais, ela trabalhava (na unidade em que antes atuava) a questão da autoridade, dos limites, saúde, maioridade penal e tenta entender como foi a adolescência deles para trabalhar também a questão geracional. Esses encontros duravam de uma hora a uma hora e meia. 
Assim, Regina disse que o papel das medidas seria o de fazer os jovens refletirem sobre "o existir deles" e nesse aspecto entra o desafio de conseguir "tocá-los a ponto de quererem conversar sobre o assunto". Ela sente que precisa encontrar uma metodologia que de fato toque os adolescentes e, conforme me contou, isso é um desafio, haja vista que geralmente "algo muito grave precisa acontecer para eles acordarem". Quando me remeto ao termo intervenção, utilizado por ela um pouco acima, ela me diz “intervenção não é bem o termo, é melhor dizer 'oportunizar', porque a mudança é ele próprio [o adolescente] que tem que fazer".

Nesse sentido, o discurso de Regina parece convergir com o de Clarice, na medida em que responsabiliza de forma mais explícita o adolescente por suas escolhas e o caminho em que ele se encontra. Para alguns, conta-me, o impacto das medidas em suas vidas não é tão grande, eles insistem em dizer "minha vida é no crime, é disso que eu gosto, o que faço de melhor", por outro lado, há relatos de "transformação bastante radical". Regina mencionou, entretanto, que o que ela chamou de "mudança sólida" não é o corriqueiro, mas a alimenta para poder saber que "pode dar certo", isto é, motiva-a para que siga com seu trabalho.

A esse respeito, ela cita uma família que tinha três filhos que passaram pelas medidas, sendo que o mais velho deles, nas palavras de Regina, "acordou". Esse filho se sentia responsável por ser um exemplo em sua família: ele voltou a estudar e entrou na Igreja. Assim, um dos trabalhos da equipe técnica tal como ela o concebe seria o de "tentar introduzir outros valores" nas vidas dos jovens, que não "os valores da rua e do crime". Um dos valores trabalhados é o da "responsabilização". Segundo ela, os adolescentes não entendem o que fazem na Unidade, que acham que as medidas "não dão em nada", como já pontuado pelas outras interlocutoras citadas acima. Os valores da solidariedade e da pertença também são trabalhados com os jovens.

Regina me disse que busca fazer com que os jovens se sintam pertencentes a um grupo e a uma comunidade, pois sente que eles "não são pertencentes a nada, só à rua, parecem soltos" e que é necessário que eles se sintam pertencentes à sua comunidade, por exemplo, para que cuidem dela - a maior parte dos adolescentes comete atos infracionais na sua própria "comunidade", isto é, na região administrativa em que mora. Ela cita também a falta de "perspectiva dos jovens", como comentou comigo, durante os atendimentos é elaborado o chamado PIA, Plano Individual de Atendimento, em que o jovem deve elencar algumas metas com as quais deve se comprometer durante o cumprimento da medida socioeducativa, e acontece de indagarem às profissionais: 
“como vou pensar no futuro se luto todo dia para estar vivo?”. Como disse Regina, "é muito grave um menino com 18 anos de idade não ter "perspectiva"'.

Regina afirmou que, por começar na internação provisória, o início da trajetória dos adolescentes no sistema socioeducativo já é impactante. No início, diz, há chance de eles aderirem à proposta da inserção na escola e no trabalho, mas a "responsabilização tem que chegar junto". Ela pontua que essa inserção seria uma forma de "intervenção mais prática" na vida dos jovens, isto é, marcos objetivos do trabalho. A outra faceta das medidas diz respeito à abertura de "portas e janelas para fazer a realidade ser transformada, para que ela [a medida socioeducativa] possa fazer sentido na vida dele [do adolescente]". Contou-me que "a escola, infelizmente, não faz sentido para eles" e que eles faltam muito e abandonam a escola, geralmente da quinta para sexta série. A hipótese dela é que os adolescentes encontraram "coisas mais interessantes para fazer na rua, com os amigos".

$\mathrm{Na}$ verdade, tal como ela entende, deve haver uma intervenção mais subjetiva, de valores, para que se concretizem de fato os "marcos objetivos" das MSE. A consequência de uma reflexão mais aprofundada sobre a vida é atingir esses marcos objetivos e "empoderar as pessoas". A intervenção subjetiva aliada a políticas com "melhor olhar" seriam capazes de gerar mudança de significado da vida do adolescente. Perguntei a Regina o que seria a "socioeducação" de que os profissionais tanto falam e no que ela diferiria da "educação". Tal como colocado pela supervisora, a educação é uma política "da educação" enquanto que a "socioeducação" seria uma política do sistema socioeducativo, que abordaria a "educação social [do adolescente] em função do conflito com a lei", em que se trabalha a "responsabilização por viver numa sociedade, no que isso implica". Assim, conforme me contou Regina, no âmbito da "socioeducação", "educar seria no sentido de "valor humano"”.

Com relação à dificuldade do trabalho que desenvolve, Regina pontua que grande parte do que tem que ser feito no âmbito do serviço prestado na Unidade é "fazer com que outras políticas funcionem" e muitas vezes o acompanhamento é difícil porque "o diálogo [com outras políticas, como as da saúde] não se sustenta". Ela disse se sentir motivada para fazer o trabalho quando consegue "tocar os adolescentes e sente que pode fazer a diferença na vida deles". Ela comenta que mesmo estando num papel de gestão, ela não deixa de atender os adolescentes, trabalho dos técnicos. Desmotiva-a, por outro lado, o que ela chamou de "questão política", a rotatividade de profissionais e a dificuldade de diálogo. Para que o adolescente "se afaste da rotina de ato infracional" é 
preciso estabelecer várias metas com ele, que vêm por meio da socioeducação, da responsabilização e dos seus desdobramentos. Os atos dos jovens trazem muitas consequências, como Regina diz, não é incomum que a família se mude de residência para fazer com que a vida do adolescente mude. É preciso, diz ela, “entrar na realidade e trazer alguma harmonia e estabilidade".

Tendo em vista a sua formação como psicóloga, Regina entende que os adolescentes não são vistos e que cometem o ato e chamam atenção para ele. $\mathrm{O}$ adolescente, diz, “é um ser que ainda está em desenvolvimento e então ocorre o fato marcante [o ato infracional], dá para contribuir para o crescimento deles, entrando na vida deles sem bater de frente". Ao mesmo tempo em que ela acredita que o profissional tem que ter o pulso forte para que os adolescentes entendam que a medida que "pegaram" é "medida judicial”, ou seja, uma "penalização" pelo que fizeram, também têm que vê-la como "algo reeducativo diante do que ele achava que era a vida dele". O profissional tem que ser às vezes mais duro que é "a sua natureza" e saber trabalhar tanto na perspectiva da "responsabilização" quanto na da "ressocialização", ele tem que ser o "pai determinante do limite e a mãe que acolhe". Por isso, entende que o limite e o acolhimento têm que conviver, mas que este é tênue e que depende, inclusive, da personalidade do especialista e da do adolescente. Existem pessoas mais acolhedoras, por um lado, e pessoas mais firmes e disciplinares, por outro.

Ela também mencionou o entendimento dos adolescentes de que a medida "dá nada não", que os adolescentes não a veem como punição e responsabilização. Citou também que muitos não entendem os sentido da PSC: "para que trabalhar aqui duas vezes na semana e de graça? Não vou receber nada". Ela diz que "eles não entendem o sentido da PSC, que é o de pagar o mal causado à comunidade". Ela diz que alguns "escolhem não fazer sentido" e que ela espera que a medida os toque e que "faça sentido" para eles. Regina menciona a experiência bem sucedida do Zoológico, que é entidade conveniada onde muitos adolescentes de UAMAs diversas do DF prestam serviço à comunidade no âmbito da PSC. "Lá existe uma proposta de educação ambiental bem forte", fala Regina. Ela entende que o sucesso do cumprimento da PSC, em certo sentido, depende muito das pessoas que a conduzem junto aos adolescentes, porque "quando a pessoa é apaixonada pelo que faz, ela contagia os adolescentes, que depois querem fazer veterinária ou biologia, coisa que eles nem pensavam que eles podiam querer antes". 
Uma hipótese da supervisora, para além da boa condução do trabalho no zoológico é a de que como os adolescentes cuidam de animais, eles se sentem tocados e aquilo "faz sentido para eles": "cuido de uma outra vida e por que não cuido de mim e não faço as coisas por mim mesmo?". Assim, o trabalho da PSC começaria na ótica da "responsabilização", isto é, como mais uma consequência do ato cometido, mas acabaria por "fazer sentido para o jovem" que, após a experiência, "começaria a correr atrás" da sua própria vida. Nesse sentido, ele teve uma responsabilidade atribuída ele e por isso estava lá trabalhando, mas depois ele próprio se engajou naquele trabalho, teve atitude e pró-atividade.

Do modo como exposto por Regina, fica claro que a medida deve abrir espaço para que sejam trabalhados significados, uma reflexão mais aprofundada e o sentido do trabalho e só quando esse é verdadeiramente compreendido e internalizado pelos adolescentes é que pode haver mudança. O comprometimento, fala ela, é que faz dar certo. A medida tem que ser um misto de responsabilização com acolhimento, tem que ser entendida como uma penalidade, mas também como uma possibilidade de mudança. A escola e o trabalho nesse sentido seriam "aspectos formais" das medidas que “chamam para a responsabilização".

Ainda em março, conversei também com Marcelo e com Isadora, os dois pedagogos da Unidade. Marcelo começou me contando como funcionavam os atendimentos, especialmente citando a atuação dos ATRS, que me era pouco conhecida até então. Eles seriam responsáveis por fazer ligações, visitas domiciliares, bem como procurar resolver questões de matrícula dos adolescentes na escola. Eles são mais presentes no início do atendimento do jovem, quando é feita a sua acolhida e quando são preenchidas informações básicas a seu respeito em uma ficha, disse Marcelo. A partir do quarto e quinto encontro com o jovem, o ATRS não se faz mais tão necessário, pois a realidade do jovem já é conhecida e o momento dos atendimentos é reservado especialmente para que o profissional cobre do adolescente o que acordaram nos encontros iniciais, especialmente o que foi incluído no PIA do adolescente.

Conforme me contou, a "mente do adolescente não se abre" no primeiro atendimento, eles costumam não falar ou mentir sobre sua condição de saúde, sobre drogadição e é o estabelecimento do vínculo que possibilita maior efetividade do trabalho dos profissionais. Se não se estabelece esse vínculo e se o adolescente não se abre, se não há confiança, fica difícil estabelecer o diálogo com eles e o atendimento fica muito burocrático. É preciso construir essa confiança, até porque eles vão para o 
atendimento porque são forçados pelos pais e pela imposição judicial. Muitos acham que é só ir para "assinar", para cumprir uma frequência determinada.

Marcelo comenta que eles não têm conhecimento da medida, que nas instâncias por onde eles passam antes de chegar à UAMA, não há essa explicação, muito pela "correria" dos profissionais que trabalham nesses locais, de modo que lhes falta tempo hábil para explicar aos meninos do que se tratam as medidas. Nem na audiência, diz Marcelo, eles têm noção do que vão cumprir. A maior parte dos adolescentes têm chegado à UAMA por remissão, isto é, o que Marcelo e Denise entendem como "perdão da justiça pelo ato cometido quando não se pode afirmar com certeza que o adolescente esteve envolvido com ele" (ver capítulo 1). Assim, o adolescente recebe a remissão e é designado a cumprir alguma medida socioeducativa. Caso ele aceite o cumprimento, o processo é encerrado e começa a cumprir a medida que lhe foi designada. Se não aceitar, o processo continua aberto e seguem-se as investigações. A maior parte dos meninos chega à UAMA sob acusação de roubo, tráfico e furto.

Marcelo disse que o cometimento dos atos pelos adolescentes se relaciona muito à região onde vivem, à renda familiar e ao fato de pertencerem a famílias desestruturadas. Muitos cometem o ato para terem ganhos financeiros, "para comprar roupa ou tênis que acham legal". Normalmente têm idade entre 12 e 18 anos, e a "influência acontece muito". Nessa faixa etária, diz Marcelo, "qualquer um os leva na conversa e eles acabam cometendo os atos infracionais".

Nesse momento de suas vidas, a adolescência, Marcelo entende também que eles precisam se afirmar, estão imaturos ainda e em processo de formarem a sua opinião. Segundo ele, muitos cometem atos não em virtude de falta de informação, mas sim por falta de formação, de caráter, de personalidade, por não saberem, por exemplo, dizerem sim e não. Assim como as interlocutoras, Marcelo também vê o papel dos profissionais como "limitado", porque depende da abertura do adolescente para ir dialogando e orientando, senão "fica vago o atendimento". Para "o menino ver sentido no atendimento", é preciso que seja estabelecido um vínculo. "Pela imposição, ele até vai, mas para ele ver um sentido naquilo depende do vínculo do profissional com o jovem e com a sua família", diz, especialmente com as mães, que são as mais presentes nas vidas desses jovens. Ele cita a constante ausência da família nuclear na vida dos meninos e o fato de existirem várias conjunturas de família. No primeiro atendimento, meninos e famílias não sabem das MSE, por vezes a mãe desconhece inclusive o ato que o filho cometeu. Mas Marcelo alerta que não há uma receita, é caso a caso. Ele vê as principais 
causas para os adolescentes cometerem os atos como sendo a falta de afetividade no seio familiar e a desestruturação das famílias. Como exemplo, ele cita o fato recorrente de as mães trabalharem fora de casa o dia todo e "o menino ficar na ociosidade e não frequentar a escola". Ele completa:

Então chega a adolescência, essa fase de afirmação, em que o menino quer acompanhar os colegas e para isso procura o crime e não trabalho porque é uma oportunidade que aparece como mais fácil no meio em que ele vive.

$\mathrm{Na}$ UAMA trabalham profissionais formados em pedagogia, psicologia e serviço social. Marcelo, como dito acima, é pedagogo. Ele passou em dois concursos em 2010, um da Secretaria de Educação do DF e a outra da Secretaria de Justiça, secretaria à qual se vinculava o Sistema Socioeducativo à época. Assim, ele trabalha na educação e também na socioeducação, na UAMA. Na área da educação, ele dá aula de alfabetização desde 2011 e na UAMA trabalha desde 2012, quando foi chamado pelo concurso. Ele não tinha "focado" especialmente no trabalho da socioeducação, entrou nessa área, pois o concurso apareceu como uma oportunidade para ele, assim como para a maioria, diz. Ele disse se sentir desmotivado muitas vezes com o trabalho que realiza, mas que acredita que quando "nos propomos a fazer algo, temos que fazer bem feito".

A desmotivação vem do fato de ele não conseguir o retorno do seu trabalho. Contou-me que se o profissional entra nesse trabalho com alta expectativa, ele se frustra. Deixa-o contente o fato de o adolescente ir para o encaminhamento dado e não reincidir, mas o retorno às vezes é pequeno e a reincidência é muito grande. Por vezes, ele diz, o NAI e a família avisam de novo ato que o menino acompanhado pelo profissional comete e isso frustra o profissional que vem trabalhando com o jovem, "que se prontificou junto ao profissional a não reincidir". Assim, o ato da reincidência, tal como compreendo do discurso de Marcelo é frustrante também na medida em que soa para o profissional como uma promessa quebrada ou não cumprida, isto é, conquista-se a confiança do menino, estabelece-se o vínculo e firma-se um compromisso com ele que, em seguida, é rompido.

Assim como no discurso da supervisora Regina, Marcelo falou-me da importância de a equipe de educadores sociais tentar buscar para o jovem um "sentido" na escola e no trabalho e da falta de diálogo do jovem em casa e na família, da "falta estrutura familiar". Segundo esse profissional, é comum casos em que "o filho vai pra rua e some". Na perspectiva de Marcelo, "a rua tem violência, tráfico, consumo de 
substâncias e os meninos não têm noção desse perigo que acontece". Os limites com o socioeducando, diz, tendem a não serem cumpridos, e os pais frequentemente querem que os profissionais frisem esses limites junto aos seus filhos, reforçando, por exemplo, que eles não podem chegar em casa depois das $22 \mathrm{~h}$. "Então, os meninos já chegam à UAMA numa constante de não cumprir ordens e regras", diz Marcelo. A imposição de regras gera um desconforto neles. Às vezes, sobre a UAMA, eles dizem: “eu vou, mas vou ficar de boa", o que denota menos comprometimento do que seria o desejado, parece-me. Então, o pensamento dos profissionais frente a esse comportamento deles é, segundo Marcelo e apareceu um pouco na fala de Clarice também, de que o menino nem iria, mas se já foi lá algumas vezes pelo menos é melhor do que nada, caso os cobrassem muito e levassem tudo "a ferro e fogo, dificilmente os meninos cumpririam". O desenvolvimento dos socioeducandos, buscado pelos profissionais, precisa fazer "sentido" para eles. Para vários já fez sentido e eles passaram a estudar e a trabalhar. Marcelo disse que:

A responsabilização precisa fazer sentido para eles, o jovem precisa entender que a "responsabilidade" é dele, que quem cometeu o ato foi ele, então é ele que tem que cumprir a medida e não os seus pais. Têm que ter o apoio dos pais, claro, mas o fazer cumprir, pelo diálogo.

Marcelo menciona o caso de uma mãe que pediu que seu filho fosse internado, num sentido punitivo, e ele responde que a lei não permite que haja a internação a pedido dos pais. Essa situação apareceu algumas vezes nas falas de outros profissionais e, inclusive, foi um dos temas da oficina de pais que presenciei: os responsáveis legais “não sabem mais o que fazer" e "preferem ver os seus filhos presos". Essa vontade, tal como pude perceber, relaciona-se não só a uma situação de desespero por perda de controle e autoridade sobre os filhos, mas também ao medo de que algo lhes aconteça "na rua", haja vista que essa é identificada com o perigo e o risco (ver capítulo 4). A rua, tal como me disse Marcelo, é onde há "violência, tráfico e consumo de substâncias".

Com relação às medidas em meio aberto, Marcelo diz que a questão é que "eles estão livres, eles vêm se quiserem, o Estado não pode impor para eles virem aqui [para a UAMA]". Na internação, há um contato mais próximo do profissional com o adolescente, ao passo que na UAMA não e então o senso comum diz que a medida em meio aberto "não dá em nada".

A forma de argumentar acerca da necessidade de comparecimento do jovem à unidade é acessando a figura do juiz, eles dizem: "se você não vier, vou mandar 
relatório de descumprimento para o juiz". Essa seria uma outra forma de "pôr medinho" no adolescente, como dito por Denise em relação à possibilidade de apreensão do adolescente em medida pela polícia. Em termos de estratégia de atendimento, pergunto do papel da escola e do trabalho e Marcelo me diz que "todos têm que estar na escola, essa é uma política de Estado", o que por si só já justificaria a necessidade de que os meninos estejam frequentando a escola. Para além desse fato, Marcelo entende que é mais fácil o Estado estar presente na vida desses jovens por meio da escola e do trabalho do que por outras políticas públicas, como as de cultura e de lazer, então, esse é o mínimo que eles têm que cumprir. O problema da escola, novamente, aparece no discurso da seguinte forma: "mas ele não vê sentido na escola".

No que se refere à "mudança", Marcelo pontua que já a viu ocorrer e que, quando isso acontece, o jovem efetivamente muda seu comportamento em casa, passa a auxiliar a família com uma renda, muda seu vestuário, sua forma de se portar, uma vez que "ele se vê como indivíduo, como pessoa, é alguém e tem importância na família e passa a ter resposta para as perguntas 'o que é você? O que você faz?"'. A disciplina deles, diz Marcelo, também melhora. Para a mudança de comportamento, a escola contribui na medida em que estipula horários para os jovens, por exemplo, e algumas regras. Assim, eles se tornam mais pontuais, passam a ajudar em casa, fazer a tarefa da escola, arrumar a própria cama e, em suma, fazer o que deveria ser "algo normal, mas que antes não era”. Quando o indago sobre a socioeducação, ele me diz que ela vê o adolescente como um "todo", mas que também trabalha com as "demandas por encaminhamentos".

O vínculo, para Marcelo, não deve ser estabelecido só a partir do ato que foi cometido. É preciso que se trabalhe com o jovem o "dizer sim" e o "dizer não", para que ele não se deixe influenciar. A visão dos profissionais, diz ele, é “de cima”, eles não estão no "meio social" aonde os jovens estão inseridos, locais com infraestrutura precária, "numa realidade complicada e insalubre e aí vem o profissional e cobra do jovem algum comportamento normal". Ele cita que o ato pode se dar por uma motivação ou pode ser um "fato isolado" na vida do jovem, mas que, em geral, existem “outras situações por trás, um somatório de coisas".

Como dito por outros profissionais, Marcelo fala da força da religião nesses contextos. Ele me contou que certa vez a mãe de um menino em medida pediu a ele que fosse à igreja. Ele foi e lá se sentiu "acolhido, pertencente a um grupo, não reincidiu, parou de consumir substâncias psicoativas" e agora vai à UAMA. Desse modo, como já 
dito pelas técnicas, o "pertencimento a um grupo que faça o adolescente se sentir acolhido", em especial a um grupo que pregue coisas boas, como Marcelo vê a Igreja, seria essencial para a mudança de comportamento dos jovens. Se pertence a grupo que “comete atos", ele provavelmente cometerá atos também, mas a Igreja prega coisas boas, como o amor ao próximo. Apesar disso, Marcelo diz que no meio aberto a religião não tem tanta força quanto tem na internação, onde, especialmente a igreja evangélica, tem forte presença. Para Marcelo, a religião propicia conforto e mente mais tranquila, mas é preciso que a pessoa veja sentido e se sinta parte dela para frequentar a Igreja, caso contrário, não vai frequentar.

Marcelo diz que durante os atendimentos, questiona o jovem sobre como ele se vê daqui a um mês ou três meses, se ele se vê na faculdade ou trabalhando e que dificilmente eles dizem que não se veem trabalhando ou estudando e então ele tenta traçar metas para eles alcançarem, para trabalharem com algo, "serem alguém na vida" e eles sabem do percurso, mas "tem algo no meio (escola? Família? Drogadição?) que os impede e os leva ao ato". Ele cita que na adolescência se começa a impor à pessoa que se torne "cidadã": "sociedade impõe à gente se tornar cidadão, pontos são impostos, o homem tem que se alistar, todos têm que ter RG e CPF”. A adolescência também é, diz Marcelo, "a fase em que o jovem quer se afirmar entre os seus pares e quando esses estão no crime, é para esse lado que ele vai". Com relação ao "sentido" das medidas em meio aberto, Marcelo percebe que a PCS tem mais sentido para eles, um sentido mais objetivo, fica claro para ele que o jovem que está em PSC está pagando por aquela situação que ele criou e, por isso, "tem mais sentido". Inclusive, contou-me Marcelo, que durante uma oficina em que os técnicos inventaram uma situação hipotética com um adolescente fictício para captar a perspectiva de adolescentes atendidos, esses foram até bem duros com o adolescente fictício e ficou claro que a PSC tem mais sentido que a LA, pois a liberdade nesse caso se confunde com "permissividade" e isso traz dificuldade para os profissionais. Na PSC, o jovem vê mais sentido, pois, conforme me contou Marcelo, ele vê um fruto do que ele está fazendo, o trabalho tem um resultado. Contribuem para a não reincidência, na visão de Marcelo, o comparecimento do jovem e de sua família na UAMA, quando ocorrem os encaminhamentos necessários e família e jovem de fato comparecem aos locais indicados, e se o jovem consegue "o mínimo", que seria ir para a escola, trabalhar, comparecer à UAMA e dar seguimento aos encaminhamentos. 
Pedagoga formada pela UnB, Isadora entrou no "sistema" por concurso em 2010, e logo foi trabalhar na UAMA visitada. Antes disso, ela tinha trabalhado como voluntária na "parte social, com população carente". O ingresso na carreira, entretanto, "veio pela oportunidade, não focando no trabalho", assim como ocorreu para a maioria dos profissionais. Isadora conta que como antes trabalhava na educação, entrar para o sistema socioeducativo significou uma "mudança de ares". Ela se especializou em gestão de pessoas, pois queria ter "uma visão mais ampla do pedagogo". À época de seu ingresso no Sistema Socioeducativo, a área era desconhecida, mas por ter família no direito, sentiu-se estimulada a trabalhar com as medidas, cujo ensinamento ela não teve na faculdade.

Se para esse tipo de atuação como pedagoga das MSE ela não havia sido preparada, o fora para o magistério e para a atuação como orientadora educacional. Quando entrou na carreira, ela disse que foi difícil, pois não ainda não havia tido pedagogo na unidade, só psicólogos e assistentes sociais, de modo que o seu papel na unidade não estava claro nem para ela e nem para a equipe técnica. Quando ela entrou, ela fazia outra coisa, ao invés de atender por completo alguns jovens, ela atendia a todos, buscando a escolarização de todos e a parte de profissionalização de todos e quem fazia os atendimentos eram psicólogos e assistentes sociais. Aos poucos, começou-se a discutir o papel dos pedagogos nas unidades de atendimento em meio aberto, que antes só executavam a LA, pois a PSC era executada pela "central" - a coordenação do meio aberto na Secretaria -, que depois passou a ser executada pelos pedagogos. O primeiro convênio feito para a execução da PSC foi com o zoológico. Em 2013, foi elaborado o Projeto Político Pedagógico para as MSE no DF, que teve a intenção de padronizar os atendimentos e o pedagogo ficou tendo o mesmo papel que os psicólogos e assistentes sociais, isto é, de atender integralmente a um certo número de adolescentes.

A motivação de Isadora para o trabalho é a de dar oportunidades para os adolescentes, mostrar a eles "outra visão". Segunda ela, eles apresentam vínculos familiares fracos e uma "questão social". Ela disse ouvir deles: "nasci aqui, vou viver e morrer aqui". Disse ainda que eles se veem marginalizados. Nesse sentido, a motivação para o trabalho com a "questão social" vem também da possibilidade de fortalecer vínculos e a autoestima dos jovens, mostrando-lhes que há oportunidade de mudar a trajetória deles. Motiva-a ver as vidas mudando e o que a desmotiva é o fato de as 
outras políticas "não funcionarem tão bem" e, em virtude disso, ser difícil ver a mudança e ter o seu próprio trabalho "travado":

Por exemplo, se depende da educação para matricular, não há vaga ou para fazer um curso profissionalizante, não tem curso para o jovem, há também deficiências na saúde. Também os adolescentes não vão para o encaminhamento e não tem como se tratar, nem trabalhar e nem estudar e então acaba reincidindo.

Em sua percepção, tem havido mais reincidência ultimamente, o que desmotiva Isadora e prova que as políticas públicas estão fracas. Ela afirma que "há mais para desmotivar do que para motivar, que tem que ter amor pelo que faz para conseguir ficar, paixão e criatividade". Ela disse que quando entrou ela "ia dando jeitinhos" para conseguir fazer o trabalho acontecer, mas que agora ela prefere não fazer isso, para não "assinar embaixo" das condições ruins de trabalho. Ela entende que no seu papel como especialista, "tem que ter um bom olhar" e que o socioeducador deveria trabalhar na sua especialidade, mas que da forma como as coisas estão, ele acaba fazendo um pouco de tudo. O profissional tem ainda que ter um olhar crítico, ver as necessidades da família e fazer bons intervenções, tentar "modificar um pouco a vida dessa família e mudar trajetória de vida".

Sobre os meninos, ela me disse que, em geral, eles têm baixa escolaridade e não conseguem se profissionalizar e que a escola, além de prover aprendizado e sabedoria a eles, é importante para criar um "projeto de vida". Muitas vezes, disse-me, "os meninos não sabem o que querem ser ou não pensaram nisso e têm autoestima baixa e não têm projeto de vida, o que os profissionais devem tentar traçar junto com ele, ajudar a pensar em profissão". Perguntei como a escolarização e a escola podiam contribuir para eles, para sua mudança. Ela disse que a escola pode ajudar no disciplinamento, por conta dos horários, do seu pulso mais firme para controlar e o trabalho também. Ela disse que quando eles começam a trabalhar, a responsabilidade muda, nem para todos, mas para alguns. No geral, ela disse ver mudança.

Isadora vê a escola como "complicada, porque tem trabalho contrário, há preconceito contra o adolescente em medida", como pontuado por outros profissionais. "A escola", diz a pedagoga, "rejeita o adolescente em medida e então ele não vê a escola como acolhedora". Isadora entende que todos têm que ser tratados igualmente, pois para ela os adolescentes, estejam eles cumprindo medidas socioeducativas ou não "têm as mesmas especificidades", isto é, ela defende que as necessidades dos 
adolescentes que estão em medida e dos que não estão em medida são as mesmas, haja vista que todos se encontram numa mesma fase de vida, "a adolescência", e que a escola não deve estigmatizar os alunos que estão cumprindo as MSE. Ela me contou que quando a escola "compra a briga" desses meninos, "muita coisa muda", mas quando a escola rejeita o jovem, é mais difícil. O contexto do adolescente é novamente recuperado: adolescência é fase do desenvolvimento, dos hormônios, descobertas, de adrenalina e dos amigos. Essa fase, a adolescência, aliada a um contexto que envolve um certo tipo de amigos e uma certa situação familiar e social, do meio, pode se tornar situação de vulnerabilidade. Nesse sentido, a visão diferenciada da situação penal dos adolescentes tal como dada pelo ECA é essencial, pois, segundo ela: "tem que haver mesmo um olhar diferenciado porque o adolescente não pode ser responsabilizado como [se fosse] adulto".

Perguntei sobre o termo socioeducação e ela me disse que acredita que a sua utilização tenha a ver com o fato de essa "socioeducação" trabalhar com "eixos sociais", ao passo que a educação se foca no saber e a socioeducação trabalha em todos os eixos: assistência social, saúde, esporte, cultura e lazer. A concepção da socieducação para Isadora, portanto, seria mais "holista", pois vê o adolescente como um todo, uma parte mais ampla dele, vê-o em seu "projeto de vida" e trabalha com recorte para formar um "todo". Perguntei a ela também como ela achava que os adolescentes viam as MSE e ela me disse que isso depende da idade do jovem e do fato de ele ser ou não reincidente. Contou-me que quando o adolescente é mais novo, tendo 13 ou 14 anos, ele vai à UAMA com medo, tem mais temor; já o reincidente, aquele que já praticou vários atos, já tende a pensar que "não dá nada não, se eu for ou não, não dá em nada".

Em seu modo de ver, as medidas em meio aberto são mais eficazes se o adolescente cometeu o seu primeiro ato, se for bem no início de sua trajetória infracional e que a medida depende muito da família e da vontade do adolescente de mudar. A comunidade, ela diz, também tem que acolher (saúde, ONGs, cursos). No que tange à mudança de comportamento, ela vê dois perfis diferentes, cada um ligado a uma RA diferente: na RA mais afastada atendida pela unidade, as condições sociais são de uma renda mais baixa, as famílias são mais numerosas e há uma reprodução dos modelos familiares. Ela vê também uma diferença de gênero. Em sua percepção, as meninas "têm cabeça de arrumar companheiro muito cedo e a gravidez e o casamento são precoces e a sexualidade parece aflorada logo cedo". 
O que gera uma mudança de mentalidade nos adolescentes são cursos, mas eles precisam estar dispostos a fazê-los. Muitas vezes o projeto de vida deles inclui "criar família ainda muito novos". No que tange à mudança e à reincidência, Isadora me contou que quando os adolescentes viram pais e mães, querem um emprego, e então é que ela vê uma "mudança de responsabilidade". Ela cita um caso de um menino que era usuário de maconha e que foi apreendido por posse e tráfico de drogas, que não queria estudar

[ele] não queria nada, mas aí a namorada engravidou, e ele passou a se preocupar em estudar e quando começou a trabalhar reduziu o uso da maconha e agora além de trabalhar, ele estuda e faz curso. Quando os adolescentes chegam à Unidade com 18 anos - lembrar que o jovem pode cumprir medida até os 21 anos referente a um ato que ele cometeu antes dos 18 anos - querem emprego ou então quando eles começam a ter dificuldade na família ligada à questão financeira e de saúde e algum parente, eles também querem mais procurar por um emprego.

Por outro lado, Isadora não vê mudança quando não consegue "encaminhamento", isto é, quando falta a oportunidade, pois o jovem acaba "voltando para a rua". Ela vê que em quase todos os casos, os pais trabalham o dia todo e não têm tempo com os filhos. Os pais veem a UAMA como um local para desabafo e a unidade acaba assumindo um papel grande de escuta. Isadora não enxerga a medida do meio aberto como punitiva, mas como "reinserção na comunidade, como acolhedora e assistencial”.

O momento de construção do Plano Individual de Atendimento - PIA - no atendimento é aquele em que são construídas as metas que o adolescente precisa cumprir, mas Isadora ressalta que isso não é feito de forma imposta, mas junto com os adolescentes e suas famílias, visando à construção de "projetos de vida". Assim, ela vê o seu trabalho na UAMA com o papel de "abrir a visão dos adolescentes para as possibilidades, mostrar que o mundo é mais que aquilo que eles veem e vivem". Quando eles veem oportunidade nas medidas, há mudança, diz. Ela fala que nos primeiros atendimentos, os meninos parecem "agarrados na barra da saia da mãe e já no final já estão mais sozinhos". Durante os atendimentos, os profissionais também explicam aos jovens como fazer para tirar a documentação e passam "tarefas" a eles, como a de se inscreverem no $\mathrm{CIEE}^{18}$, isso, como me contou, resgata a sua autoestima. Essa conduta dos profissionais faz parte de um entendimento de que o adolescente tem

\footnotetext{
${ }^{18}$ Sigla para Centro de Integração Empresa Escola, que contém um cadastro de estudantes para fazer a intermediação deles com o mercado de trabalho.
} 
que "aprender a fazer certas coisas sozinho para continuar com plano de vida", então veem-se mudanças no que se refere à responsabilidade e independência dos jovens. Na visão de Isadora, a "responsabilização" sobre o ato infracional, algo tão citado pelos técnicos, inclui uma "reflexão sobre o ato", e possui um sentido mais geral, ligado, por exemplo, ao percurso dos adolescentes para "tirarem os seus documentos". Mas a reflexão tem que ser indireta, diz Isadora, pois "confrontar os jovens não dá muito certo, adolescente não gosta que batam de frente com ele". Assim, ela entende que tem que haver um "reforço positivo", fortalecendo-se outros vínculos para ele se desvencilhar dos negativos.

No que tange às diferenças com relação à realidade da internação, a pedagoga pontua que:

$\mathrm{Na}$ internação o menino está lá o tempo todo, está lá com liberdade restrita, não tem contato com comunidade e família. Então, para atendimento lá é mais fácil, eles estão lá, ao passo que no meio aberto se ele não quiser ser encontrado, ele não é, portanto, é mais difícil dar o atendimento, é comum marcar e eles não aparecerem. Na internação, o contato com eles é mais direto e intenso, mas lá não se conhece tanto a comunidade deles. A UAMA já se insere na comunidade, há uma relação mais aberta com a escola para onde encaminhar o adolescente, por exemplo. Já no caso da PSC, como o profissional que guia os adolescentes no local do cumprimento da medida passa quatro horas direto com eles, a socioeducação é mais próxima. Na PSC, como tem horário de entrar e sair, a "responsabilização" é maior.

Isadora entende que o papel da LA acaba se voltando a mais a sanar situações de maior vulnerabilidade social, de resolver, portanto, questões de matrícula na escola, necessidade de CRAS ou de algum tratamento de saúde. Da ressocialização dos meninos, é esperado que eles criem um "plano de vida" e que continuem com os encaminhamentos dados na UAMA para as outras políticas. Isadora sente que falta política para egressos do sistema socioeducativo. Quando os meninos já têm atividades e trabalham, os profissionais os incentivam a continuarem fazendo as atividades e a continuar no trabalho.

No que diz respeito à religião, Isadora diz que os meninos não falam muito de religiosidade e quando ela é presente, a mudança é mais fácil, há mais reflexão e "gastam seu tempo com a Igreja, que também tem uma parte assistencial importante", diz ela. Ela me contou que quando os meninos têm religião e de fato a seguem, "ajuda no processo de reflexão e assim também os adolescentes têm o seu tempo voltado para outras atividades", que é uma preocupação da equipe técnica, que quer "ocupar o tempo dos meninos para não que eles não fiquem na rua para que eles não voltem a se inserir 
com seus pares". Então, os profissionais trabalham para o adolescente voltar para a Igreja justamente por essas razões citadas. Mas isso ocorre quando o adolescente já estava previamente inserido em alguma religião, pois Isadora lembra que "o nosso país é laico e assim os profissionais não podem obrigar os adolescentes a seguirem nenhuma religião". Por isso, é importante que o profissional conheça a região de residência do jovem, para sugerir opções para ele quando ele chega a UAMA sem uma atividade prévia, como, por exemplo, frequentar uma determinada Igreja. A mudança, diz Isadora, “depende muito deles e da família, o comprometimento da família facilita a mudança, quando há envolvimento verdadeiro da família, vê mais mudança". Segundo ela, os seguintes fatores contribuem para a mudança: "o comprometimento da família, funcionamento das políticas, disponibilidade e vontade do próprio adolescente, e a conscientização da comunidade, que deve estar aberta para acolher".

Ela fala que alguns adolescentes sentem a LA e a PSC mais como uma punição, uns acham que não deveriam cumprir:

eles não têm noção de que eles têm que responder para a sociedade pelo que fizeram, eles não têm regras e limites, não veem as medidas como uma oportunidade. Às vezes, quando eles são incluídos na escola ou no Jovem Candango, essa visão deles vai mudando, veem com agradecimento e continuam "dando satisfação" aos profissionais, tendo enxergado as medidas como "uma oportunidade de mudança". Alguns também reconhecem a UAMA como local de oportunidades e não só de punição.

Assim, compreende-se do discurso de Isadora que o aprendizado dos meninos passa pela noção de que eles têm que refletir que estão na UAMA porque fizeram algo errado, que estão respondendo à sociedade pelo ato praticado, mas também ver como oportunidade. Ela afirmou ainda que:

Se não refletir sobre o ato, não vincular medida ao ato cometido, dificulta até na questão da reincidência, eles precisam entender que são regras da sociedade que eles quebraram. Muitos não têm limites e regras e isso é necessário na UAMA, mas muitos não têm isso em casa. Na vida a gente tem, né? Têm que aprender isso aqui porque no resto da vida eles vão ter.

Como limites de sua atuação, Isadora vê a própria Secretaria, o fato de serem cobrados por uma série de "trabalhos burocráticos", o que reduz a qualidade do atendimento. A limitação também se dá em virtude da falta de materiais e das condições de trabalho. Falta também, ela diz, investimento em formação continuada e troca de experiências. 
Em junho, após uma grande mobilização midiática em torno da redução da maioridade penal, discutida no Congresso Nacional, voltei à UAMA. Nesse mês estava sendo discutido também, em Brasília, o Plano Decenal de Atendimento Socioeducativo do DF, 2015-2024, que, conforme me disse Regina, contou com a escuta de adolescentes do sistema, de seus responsáveis legais e de profissionais do socioeducativo para a sua formulação. Disse-me que escutara, por ocasião dos encontros com os adolescentes, uma série de dúvidas e incompreensões acerca da redução da maioridade penal. Chegou a ouvir, por exemplo, adolescentes que estavam contentes com a possibilidade da redução por crerem que iriam poder tirar a carteira de habilitação aos dezesseis anos de idade. Regina disse também conduzir oficinas com os jovens na UAMA para afastar essas incompreensões e para fazê-los refletir. Muitas vezes eles chegam à Unidade com alguma opinião, mas mudam em grupo o que pensam. Eles precisam, diz Regina, “escutar histórias que fazem pensar”. Ao ouvirem os adolescentes para a elaboração do plano decenal, era comum que eles pedissem idas ao cinema, exposições e campeonatos esportivos entre as UAMAS, por exemplo.

$\mathrm{Na}$ oficina com os pais para a formulação do Plano Decenal, era comum ouvir, disse Regina, pedidos para um acompanhamento mais rígido dos adolescentes que cumprem medidas socioeducativas em meio aberto. Regina compreende que, para eles, estar em liberdade é como se os adolescentes não tivessem pagando pelo que fizeram. Ela diz que falta esclarecimento de que meio aberto também é forma de responsabilização.

Em junho, também tive a oportunidade de conversar com Aline, a única assistente social em atuação na UAMA. Formada em 2010 em Serviço Social pela Universidade de Brasília, Aline passou no concurso da carreira do sistema socioeducativo, como os demais, e esse é o seu primeiro emprego. Ela me lembra que a carreira a que pertence é do socioeducativo e não mais da Assistência Social, isto é, que o seu vínculo é com a Secretaria da Criança. Lembra ainda que a política socioeducativa já fez parte da Secretaria de Justiça, mas que agora tendo uma "secretaria própria", a política teria mais autonomia e seria sinal de que o Estado reconhece o sistema socioeducativo como uma política.

A prioridade desse governo, tal como Aline entende, não é o sistema socioeducativo. Para ela, existe uma priorização clara da internação: desativaram o CAJE, mas construíram novas unidades de internação. "Quando se investe mais na internação do que no meio aberto, fica claro que o governo acredita que tem que deixar 
eles na internação, isolados”, afirma Aline. Do ponto de vista do ECA e SINASE, que é reeducar, tinha que se investir mais no meio aberto, e construir novos objetivos e perspectivas junto com os adolescentes para eles não caírem na internação, conta.

Aline entende que a internação tem também um lado pedagógico, mas que normalmente se enxerga o lado mais punitivo na internação do que na UAMA. Ainda assim, ela acredita que na UAMA o lado é mais pedagógico, mas que a sociedade "quer pegar a pessoa e colocar na internação logo".

Aline se ressente da falta de investimento nas medidas em meio aberto e afirma que:

Não investimentos na prevenção. A gente espera acontecer para fazer algo, esse pensamento tá em várias políticas. O poder público preza mais pela punição. Não é que LA não vale nada, não é devido à medida em si, nem por conta das profissionais. Se for mais investida, se pudesse ser como no SINASE, seria ótimo. Problema não está na medida em si, é estrutural, no quesito investimento, poder público.

No que tange à discussão sobre a redução da maioridade penal, ela disse que não há um consenso entre os profissionais do sistema socioeducativo. Pessoalmente, ela se disse contra. Ela afirmou:

Meninos de 16 a 18 anos são imediatistas, não refletem, não pensam no que aquele ato pode acarretar para sua vida. Hormônios estão a flor da pele. Eles gostam de movimento, de sair, de coisas dinâmicas. Se ficar um tempo de castigo sem sair de casa já é difícil, imagina ficar 3 anos na internação? Muitos estigmatizam o menino pelo ato e não olham o resto da pessoa.

Então, pergunto a ela sobre essa tensão entre a punição e o lado pedagógico das medidas socioeducativas. Ela me diz que:

A punição é passada para eles [os adolescentes] pelo jornal, e como não tem restrição nenhuma no meio aberto, então eles não veem como algo significativo, porque não passa a eles essa sensação de punição. Comparecer aos atendimentos poderia ser um lado considerado mais punitivo da política, mas os adolescentes não parecem encarar dessa forma.

No socioeducativo em meio aberto tudo parece ser pedagógico, pondera Aline. O PIA, os objetivos e metas que eles têm que cumprir, que são elaborados junto com eles, seria algo muito positivo. Ela entende que "é muito educativo poder construir projeto de vida com o menino". Entretanto, essas metas esbarram na falta de oportunidades de estudo e emprego. A execução do PIA é algo complexo, pois não há investimento.

Aline diz que faltam oportunidades no que se refere a escola e emprego, que muitos adolescentes pedem cursos e oportunidades de estágio que os profissionais 
simplesmente não podem oferecer, pois essas não existem. Quando há cursos que eles gostariam de fazer, por exemplo, ou a escolaridade deles, que normalmente é a de ensino fundamental incompleto, não lhes permite cursá-los ou então os cursos disponíveis para a escolaridade que possuem são desinteressantes, a exemplo do curso de padeiro. "Quando não são oferecidas oportunidades a eles, eles desacreditam na medida", disse-me. Por essa razão, diz Aline, a execução do PIA é algo complexo, pois falta investimento e, por isso, há limites à atuação dos profissionais. Assim, ela se disse muito desmotivada com o seu trabalho, "lutando contra a maré". Olhando em termos de investimento, está claro, disse-me, que a prioridade do governo ainda é a punição e a repressão, haja vista recentes construções de unidades de internação no Distrito Federal e as condições mais difíceis de trabalho a que estão submetidos os profissionais do meio aberto.

Aline acredita muito na fala, pois esta poderia "empoderar" os adolescentes. Conforme a profissional:

Muitas vezes, é dito que a oportunidade é dada ao menino na UAMA e que ele não faz porque não quer nada da vida, mas esse discurso é um tanto quanto cruel, porque é difícil colocar toda a culpa nos adolescentes, dizer que eles têm que ser diferentes, que têm que se esforçar mais, ter mais força de vontade. Eles já chegam na UAMA estigmatizados e "pedindo socorro", chegam em um ponto em que todas as outras políticas já falharam com ele: a educação não deu conta, a assistência social não deu conta. Já chega pedindo socorro e é preciso construir uma nova perspectiva pra ele. A gente diz que sabe que a vida toda dele ele esbarrou na falta de direitos e na estigmatização e que várias portas foram fechadas pra ele, mas que não é pela criminalização que ele vai resolver isso, pelo contrário, só vai piorar, que a violência não é o caminho.

Aline se sente motivada com o trabalho que desenvolve quando consegue encaminhar os adolescentes para algum lugar e quando ele sai do caminho da violência. O vínculo com as famílias e com os adolescentes também a motiva, o que é muito pouco, porque a maioria já chega muito comprometido com a violência e o uso de drogas, pontua a profissional. O que a consola é saber que faz o que está ao seu alcance. Ela diz: "a culpa não é minha se eu não consigo encaminhar o adolescente, a culpa é da estrutura".

A assistente social entende que "não é culpa só deles se eles estão nessa situação, todos têm responsabilidade: a sociedade em geral, a família e o adolescente". A profissional se diz muito "idealista": "quero ver o menino mudando totalmente, nem sempre o que quero é o que eles querem. Mudança vem devagar mesmo". E ela valoriza pequenos progressos no que se refere à drogadição, por exemplo, quando o adolescente 
passa a consumir a droga com menor frequência, ainda que não abandone o uso da substância, ou quando um jovem que não frequentava a escola passa a frequentá-la três ou quatro vezes na semana.

Para Aline, frequentar a escola é essencial para que se fomente a mudança desejada nos adolescentes: "na sociedade atual", diz, "o caminho é a educação, é necessária uma escolarização mínima para se conseguir um emprego, a nossa sociedade valoriza a produção e trabalho remunerado, então o caminho é esse, escolarizar e capacitar."

O menino, diz Aline, precisa de emprego e do dinheiro para conseguir outras coisas, "mas aí esbarra na política de educação". A escola como está, diz Aline, não é atrativa e os meninos são estigmatizados no ambiente escolar. Os meninos querem ganhar mais, eles querem fazer cursos que os atraem, que eles gostem, "não quero ser padeiro", dizem alguns.

Assim, a profissional percebe que muita coisa depende dos adolescentes, de eles fazerem coisas que não gostam, de "aguentarem uma escola que não é atrativa". Aline crê que isso é muita responsabilidade para eles e que o esforço que os meninos em medida têm que fazer é muito maior do que outros adolescentes sob outras condições precisam para alcançarem situações mais favoráveis, justamente em virtude de uma escassez de oportunidades e direitos. "Acaba que tem que partir deles mesmo". Nos atendimentos, ela diz que o esforço tem que ser pessoal, apesar de não concordar com isso. Ela percebe algumas iniciativas que dão mais oportunidades aos jovens, cita o CIEE, por exemplo, que contrata socioeducandos, e o Jovem Candango, programa do GDF para empregar e capacitar jovens e que prioriza o público do sistema socioeducativo. É preciso, diz Aline, que se veja que "eles [os adolescentes] não são só a infração que cometem".

Ela vê avanços no judiciário, como o maior encaminhamento dado pelos juízes para que adolescentes cumpram medidas menos gravosas e a menor morosidade dos processos. A estrutura de trabalho também melhorou, diz ela. Antes só havia um computador na unidade e não tinha impressora. Mas como ela disse, são pequenos avanços. Ela acha as pessoas do socioeducativo "muito comprometidas" e agora vê condições mínimas de trabalho frente ao que se tinha há alguns anos. Ainda assim, diz Aline, falta investimento e o problema é estrutural. Em referência aos projetos que tramitam no Congresso para redução da maioridade penal, Aline diz achar que talvez a 
sociedade brasileira tenha que ver na prática que prender os meninos vai aumentar a revolta deles e aumentar a criminalidade.

A lógica da punição é o que prevalece na sociedade brasileira, pensa Aline. Para ela, a socioeducação tenta mudar visão da punição e colocar o aspecto pedagógico e tirar a culpabilização do adolescente e considerar outros aspectos. Como disse Aline: "Não é culpa só dele [do adolescente], há todo um passado de opressão e de carências. Todos têm responsabilidade". A profissional, talvez em virtude de sua formação acadêmica, apresentou uma visão mais crítica no que tange à noção de responsabilização frente ao que me foi dito por outros profissionais.

Para Aline, a educação escolar é só um aspecto da educação. A educação também é tentar mostrar outras perspectivas para o adolescente. "Talvez se tivéssemos uma escola menos "conteudista", talvez as medidas socioeducativas nem existissem, se as políticas funcionassem também né”, diz.

Aline entende que seu trabalho deve devolver às famílias e aos adolescentes tudo que lhes faltou, que não foi dado a eles, e tentar inseri-los nas políticas novamente. "São poucos os adolescentes que dizem cometer os atos por gostarem de fazê-lo", conta.

Sobre como conduz o seu trabalho enquanto assistente social na UAMA, Aline diz que:

Primeiro responsabilizo o adolescente, em segundo lugar a família e a sociedade. Às vezes é isso mesmo, a mãe é ausente, tem que trabalhar, mas isso esbarra também nas políticas. Tento mostrar para a família que ela também tem responsabilidade. Tento empoderar a família, dizer que são sujeitos de direitos, e que têm que correr atrás dos seus direitos. Tento falar que a culpa não é deles. Falo que culpa é do Estado também. Falo que eles têm sua parcela de responsabilidade. Há negligência familiar, mas também do Estado. Tem que olhar o que faltou na comunidade. Todos têm responsabilidade. É preciso auxiliar família, tirá-la da vulnerabilidade. Adolescentes acham que aqui [na UAMA] não vale nada, e a cultura é de que o crime é punido pelo sistema penitenciário, então eles [os adolescentes] também esperam isso.

Assim, Aline conclui que "tem que ter investimento maior, mas antes tem que mudar como é visto o tratamento a quem comete crime, ver que é uma coisa maior, estrutural".

Pelos discursos dos profissionais, começa a se delinear, portanto, entendimentos de culpabilização dos adolescentes, por um lado, em que o peso da responsabilização pelos atos recai especialmente sobre eles, e discursos referentes a um contexto estrutural, que enxerga outros atores e diversas carências, também expressas em termos de uma desmotivação em virtude da incompletude institucional da política 
socioeducativa e dos problemas com a "Rede", que contribuem para o cenário em que se encontram os jovens. Outro aspecto relevante e frequente nas falas reproduzidas acima diz respeito à frase "não dá em nada", proferida pelos adolescentes, que deixa entrever a discussão acerca das expectativas dos adolescentes - e também de seus pais quanto às medidas socioeducativas e o papel das profissionais, bem como o entendimento dos três atores acerca do que seria a "verdadeira punição" e onde se insere o componente pedagógico da política socioeducativa. Isto é, o entendimento de que as medidas em meio aberto não trazem consequências ou não funcionam parece estar relacionado a uma ideia difundida de que estar em liberdade não condiz com punição. Para além do que foi citado acima acerca do fracasso de outras políticas públicas, temse a sensação de que as medidas em meio aberto não são efetivas e eficazes não exatamente pela taxa de reincidência que, apesar de ocorrer, é maior nos contextos da internação, mas sim porque elas não privam os adolescentes de sua liberdade.

\subsection{OS "MENINOS"}

O comportamento dos adolescentes durante os "atendimentos" apareceu como outra dimensão importante das conversas entre as profissionais. Às vezes se referiam a alguns como "arredios" ou "tranquilos" e ainda faziam a diferenciação entre aqueles que pareciam mais resistentes ao cumprimento das medidas socioeducativas e aqueles que pareciam de fato se preocupar em cumpri-las e que desejavam querem "mudar" e "sair daquela vida de atos infracionais".

Como apareceu acima, nas falas dos técnicos, estes fazem uma diferença entre os adolescentes que viam "sentido" na medida cumprida e outros que iam por pressão dos responsáveis legais ou que iam, mas "ficavam de boa", denotando um menor comprometimento com as metas estabelecidas durante os atendimentos e, consequentemente, mais propensos a romper com o combinado e descumprir a medida. Aqueles que viam a medida para além de seu caráter punitivo, mencionaram alguns profissionais, conseguiam enxergar "oportunidades" e tendiam a demonstrarem mudanças mais "sólidas" em suas trajetórias.

Muitas vezes, os meninos também eram descritos pelos técnicos em função de suas vulnerabilidades: de acesso à saúde, de renda - não é incomum que os meninos não tenham dinheiro para pagar a passagem de ônibus para irem até a unidade cumprir a 
medida, por exemplo, mas como há um número reduzido de passes que podem ser dados aos adolescentes, a equipe técnica seleciona aqueles que mais precisam receber o custeio de transporte - de uma desestruturação familiar e da baixa escolarização, o que resultava em dificuldades para inseri-los em cursos, estágios e trabalhos. Era constante também na fala dos profissionais "a ociosidade perigosa" em que vivem muitos dos meninos atendidos e situações de "drogadição". Abaixo, apresento alguns dados sobre adolescentes em cumprimento de medidas socioeducativas no Brasil para, em seguida, explorar um pouco o perfil dos adolescentes inseridos no sistema socioeducativo do DF chegando, por fim, a expor características dos adolescentes atendidos na UAMA visitada tal como exposto por relatórios a que tive acesso.

Inicio pela apresentação de alguns dados da Secretaria de Direitos Humanos da Presidência, a SDH, que é a responsável pelo SINASE - Sistema Nacional de Atendimento Socioeducativo - e que apresentou, em 2014, um relatório ${ }^{19}$ contendo o levantamento anual dos adolescentes em cumprimento de medidas socioeducativas, cujos dados se referem ao ano de 2012 e fazem uma comparação com outros anos (desde 2008 em alguns casos e com os anos de 2010 e 2011 em outros). Os dados para a construção do relatório foram enviados pelas Unidades Federativas e, em realidade, enfocam mais o contexto da restrição e da privação de liberdade, mas também trazem informações que podem servir para a compreensão breve do panorama das medidas em meio aberto e, claro, do sistema socioeducativo, de forma mais ampla, no Brasil. Os dados foram colhidos por meio de preenchimento de questionário pelos Estados da Federação e Distrito Federal e referem-se à realidade do atendimento em 30/11/2012. Algumas informações presentes no relatório da SDH são oriundas do Ministério do Desenvolvimento Social e Combate à Fome (MDS) e do Ministério da Educação (MEC).

De acordo com os dados presentes no relatório, em 2012, haveria 20.532 adolescentes em restrição e privação de liberdade (internação, internação provisória e semiliberdade), e 88.022 em meio aberto (prestação de serviços à comunidade e liberdade assistida) no Brasil. Os dados mostram uma taxa ascendente de restrição e privação de liberdade de adolescentes no Brasil. O aumento dessa taxa, que apresentava variação de $10,5 \%$ entre 2008 e 2012, veio a cair de 2011 para 2012, somando 4,7\% de variação de um ano para o outro. A partir do comparativo das taxas de restrição e

\footnotetext{
${ }^{19}$ Disponível em: http://www.sdh.gov.br/assuntos/criancas-e-adolescentes/pdf/levantamento-sinase-2012, acesso em 30 de abril de 2015.
} 
privação de liberdade, de 2008 a 2012, o relatório afirma que houve diminuição do número de restrição e privação de liberdade nos Estados de Santa Catarina, Rio Grande do Sul, Distrito Federal, Maranhão, Piauí, Rio Grande do Norte, Acre, Amazonas, Amapá, Rondônia, Roraima e Tocantins. Ao contrário, houve aumento do número de restrição e privação de liberdade em Espirito Santo, Goiás, Mato Grosso e Mato Grosso do Sul, Alagoas, Bahia, Ceará, Paraíba, Sergipe e Pará. Ainda que a taxa, no Distrito Federal, tenha diminuído, o DF ainda figura como a quarta Unidade da Federação com a maior proporção de adolescentes em privação de liberdade no país, considerando-se jovens na faixa etária entre 12 e 21 anos e a população adolescente do DF. Na data da referida coleta de dados, a cada mil adolescentes que tinham de 12 a 21 anos, dois estavam em situação de privação de liberdade no DF.

Com relação ao lócus institucional da política de socioeducação nos Estados, o mais comum é que seja em secretarias ligadas à Assistência Social e Cidadania, ou então às Secretarias de Justiça e Segurança Pública, sendo o DF uma realidade à parte. Sobre isso, a psicóloga Clarice contou-me que há uma "eterna briga" sobre a compreensão do socioeducação, isto é, se ela deve ser vista como mais "punitiva", no sentido penal, o que levaria a abriga-la em secretarias de justiça e segurança, ou mais “educativa e assistencial”, o que tenderia a vinculá-la às secretarias de assistência social. $\mathrm{Na}$ época em que o levantamento da SDH enviou os questionamentos sobre os atendimentos do sistema socioeducativo aos Estados, a política da socioeducação já estava vinculada à Secretaria da Criança.

No que diz respeito ao número de adolescentes atendidos à época pelas medidas do Meio Aberto no DF, a Secretaria informou que seriam 1.243 adolescentes do sexo masculino e 121 do sexo feminino ${ }^{20}$. No ano de 2012, no Brasil, havia 67.389 adolescentes do sexo masculino e 10.373 adolescentes do sexo feminino sendo acompanhados no Serviço de Proteção Social a Adolescentes em Cumprimento de Medidas Socioeducativas de Liberdade Assistida e Prestação de Serviços à Comunidade. Havia ainda outros 12.069 para os quais não havia informação de sexo.

Dados do CENSO SUAS, pesquisa de levantamento anual de informações sobre a Assistência Social no Brasil, conduzido pelo MDS, apontam que o cumprimento de medidas em meio aberto de Liberdade Assistida e Prestação de Serviço à Comunidade aumentou consideravelmente desde 2010, quando havia 67.045 adolescentes em

\footnotetext{
${ }^{20}$ Retrato dos atendimentos em 30/11/2012.
} 
cumprimento de MSE em meio aberto, passando para 88.022 adolescentes em 2011, chegando aos 89.718 adolescentes em 2012. Ou seja, conclui o documento, houve aumento, de 2010 para 2012, de mais de 34\% no número de adolescentes em cumprimento de medidas em meio aberto. Essa progressão, conforme pontua o texto, demonstraria que a execução de medidas em meio aberto:

tem sido alvo de investimentos da Política de Assistência Social, que, por sua capilaridade, tem promovido uma articulação cada vez maior na execução das medidas em meio aberto com as demais políticas setoriais, qualificando o acompanhamento aos adolescentes em cumprimento de medidas de LA e PSC (p. 37)

O documento informa ainda que, no ano de 2012, havia 35.287 meninos cumprindo a medida de Liberdade Assistida no Brasil, 4.492 meninas e 5.954 adolescentes para os quais não havia informação sobre sexo. No que diz respeito ao número de adolescentes que cumpriam medida Prestação de Serviços à Comunidade em 2012, no Brasil, 31.846 eram do sexo masculino, 5.296 do sexo feminino e havia ainda outros 6.518 para os quais não havia informação de sexo registrada ${ }^{21}$.

Quando demonstrei aos meus interlocutores interesse em saber mais do perfil dos adolescentes que estão no Sistema Socioeducativo do DF e também da UAMA visitada, foi-me encaminhada por e-mail uma pesquisa, publicada em 2013, coordenada pela Codeplan - Companhia de Planejamento do Distrito Federal - a pedido da Secretaria da Criança, intitulada "Perfil e percepções dos Adolescentes em Medidas Socioeducativas no DF". No âmbito dessa pesquisa, foram entrevistados mais de mil adolescentes em todas as unidades de cumprimento de medida socioeducativa do DF: Unidades de Atendimento em Meio Aberto (UAMAs), Unidades de Semiliberdade e Unidades de Internação.

Foram abordadas questões sobre perfil socioeconômico, como sexo, raça/cor, idade, religião, nupcialidade, fecundidade, escolarização, renda e trabalho, sobre o ato infracional, incluindo aspectos como reincidência e quantidade de passagens pelo sistema socioeducativo, e sobre a experiência dos adolescentes na vida e no cumprimento da medida, como histórico de violência, sensação de segurança, acesso a atividades físicas, cultura e lazer, áreas de interesse para capacitação profissional e histórico sociofamiliar. O campo ocorreu entre junho e julho de 2013 e foram entrevistados apenas os adolescentes em atendimento "efetivo" vinculados à medida até

\footnotetext{
${ }^{21}$ Dados do CENSO SUAS MDS 2013, trazidos pela SDH no relatório supracitado.
} 
o dia $1^{\circ}$ de junho de 2013, isto é, não foram entrevistados os adolescentes que estavam em unidades fechadas provisoriamente, nem os que foram sentenciados no meio aberto, mas que não estavam ainda vinculados às unidades. Cabe ressaltar que, ao passo que no caso da internação foi possível entrevistar $100 \%$ dos adolescentes, no caso do meio aberto, esse percentual ficou em pouco mais de $40 \%$ dos efetivos vinculados até a data estipulada acima, devido ao grande número de ausências registradas pelos pesquisadores de campo.

De acordo com os dados da pesquisa, a maior parte dos adolescentes vinculados à PSC à época - de um total de 99 adolescentes em PSC entrevistados - residiam no Recanto das Emas (25,3\%), em Ceilândia (18,2\%) e no Gama. Dos 450 em LA entrevistados, 15,3\% residiam em Ceilândia, 6,7\% em Taguatinga e 6,7\% e 6,2\%, respectivamente em São Sebastião e Recanto das Emas. Na PSC, a maior parte era natural do DF (92,9\%), seguido de 3\% que era proveniente de Goiás, ao passo que na LA, a porcentagem de adolescentes naturais do DF cai um pouco, para 85,6\%, seguido de Goiás, com 3,1\%, Piauí, 2,9\% e Maranhão, com 2,2\%. Dos adolescentes em PSC, $96 \%$ são do sexo masculino e apenas $4 \%$, do sexo feminino. Na LA, a proporção de meninas aumenta: são $15,8 \%$ adolescentes do sexo feminino e $84,2 \%$ do sexo masculino. Fato observado em campo e que também é notado por essa pesquisa é o grande percentual de adolescentes que acumulam a medida de PSC com a de LA: 74,7\% dos adolescentes que cumprem PSC a acumulam com a LA, 22,2\% cumprem só PSC e para outros 3\% não há informação. Dos adolescentes em PSC, 9,1\% não estavam cumprindo a medida e os demais a cumpriam especialmente em Centros Olímpicos e no Jardim Zoológico de Brasília. Na PSC, 78,8\% dos adolescentes se declararam pretos ou pardos (agrupados na categoria negros) e apenas 18,2\% como não negros. $\mathrm{Na}$ LA, o percentual de negros foi de $80,2 \%$ e de não negros, de $16,7 \%$. Em termos de faixa etária, na PSC, as idades mais significativas eram de 17 anos (35,4\% dos adolescentes) e de 18 anos (21,2\%), o que se aproxima da realidade da LA, em que se tem $22,4 \%$ com 17 anos e $24 \%$ com 18.

$42,4 \%$ dos adolescentes em PSC declaram não seguir nenhuma religião, outros $29,3 \%$ disseram seguir a religião protestante/evangélica e ainda $28,3 \%$, a religião católica. Dos jovens em LA, foram $44,9 \%$ os que declararam não seguir nenhuma religião, 32,2\% a protestante/evangélica e 21,3\% a católica. No que tange à residência, na PSC, quase metade $(41,4 \%)$ dos adolescentes disse residir com a mãe, 33,3\% citaram residir com a mãe e o pai, $27,3 \%$ disse que moram também com familiares e 15,2\% 
citaram companheiros (as) como pessoas com quem residem. Na LA, por sua vez, residem com a mãe $36,9 \%$, com mãe e pai, $29,3 \%$, outros familiares, $27,1 \%$ e também com companheiros, $11,9 \%$. Ressalta-se que essas categorias não são excludentes, ou seja, é possível que um mesmo adolescente tenha respondido residir com a mãe e com outros familiares, por exemplo. Dos adolescentes em PSC, 81,8\% se declararam solteiros e $14,1 \%$ disseram viver em união. $\mathrm{Na}$ LA, foram $84,4 \%$ de solteiros e $12,9 \%$ que vivem em união. Dos adolescentes em PSC, 14,1\% disseram ter filhos e em LA esse percentual foi de $18 \%$. A escolarização, uma das principais metas da política da socioeducação e que apareceu como uma grande preocupação da equipe técnica com quem conversei, é de fato, muito baixa entre os adolescentes que cumprem medidas. No caso da PSC, 63,6\% não tinham instrução e não completaram o ensino fundamental. $33,3 \%$ tinham ensino fundamental completo e médio incompleto e apenas 3\% haviam completado o ensino médio. 46,5\% dos adolescentes em PSC disseram não estudar, isto é, não estavam nem matriculados na escola. No caso da LA, os adolescentes sem instrução e ensino fundamental incompleto são 61,6\%. Esses dados parecem mais preocupantes quando se contraste com a idade dos adolescentes em PSC e LA, que, por ser, em sua maioria, superior a 14 anos, pressupõe a finalização do ensino fundamental numa situação normal da relação idade/série. $\mathrm{Na}$ LA, são 33,3\% com ensino fundamental completo e ensino médio incompleto e 5,1\% com ensino médio completo. 49,1\% disseram não estar estudando. Nota-se que nos casos de adolescentes em situação de semiliberdade e internação, o nível de instrução é ainda mais baixo: respectivamente, $79,7 \%$ e $82 \%$ não tinham instrução e ensino fundamental incompleto.

Outra grande preocupação surgida nos discursos de meus interlocutores diz respeito à reincidência. Embora, em nossa conversa, eles não mencionassem taxas e números exatos, contavam-me diversos casos de "meninos" que estavam em atendimento na UAMA e que vinham a cometer novos atos infracionais e como isso os frustrava. De acordo com os dados da pesquisa da Codeplan, na PSC o índice de adolescentes reincidentes foi o mais baixo, $28,3 \%$, o que coincide com os discursos das técnicas de que a PSC parecia gerar um efeito mais positivo sobre os adolescentes. $\mathrm{Na}$ LA, a taxa de reincidência foi captada em $33,1 \%$. A esse respeito cabe também fazer uma breve comparação com as situações de restrição e de privação de liberdade: no caso da semiliberdade, o percentual de adolescentes reincidentes foi de 83,1\% e, na internação, de $84,2 \%$. O documento pontua ainda que: 
Nas duas medidas não restritivas de liberdade a maior parte dos adolescentes entrevistados estava em sua primeira passagem pelo sistema socioeducativo $71,7 \%$ na PSC e $67,3 \%$ na LA. No entanto, nas medidas restritivas, a maioria dos socioeducandos tem de duas a cinco passagens: $64,4 \%$ na semiliberdade e $48,6 \%$ na internação. Dentre os internos, também é grande o percentual de reincidentes com ainda mais passagens: $23,6 \%$ com seis a 10 e $11,3 \%$ com 11 ou mais passagens (p. 40).

Cumpre destacar que esse número elevado de passagens dos adolescentes da internação e da semiliberdade pode também estar ligada a uma estratégia do judiciário, e que encontra respaldo no ECA, de priorizar as medidas em meio aberto e aplicar medidas mais gravosas, como as de restrição e privação de liberdade, em casos em que se constate uma gravidade maior do ato e maior envolvimento do adolescente nele, bem como em casos de reincidência. Esse fato foi, inclusive, problematizado pelo exsocioeducando quando de sua visita à UAMA. Para ele, o sistema socioedecutivo estaria "invertido", isto é, os meninos ao invés de receberem medidas em meio aberto, mais brandas, no início de sua trajetória infracional, deveriam receber logo as mais gravosas, o que seria mais impactante na vida deles e os distanciaria dessa trajetória, pois quando o menino é internado, nas palavras do ex-socioeducando, "não adianta mais, ele já tem doutorado no crime".

No que diz respeito ao tipo de ato infracional cometido, na PSC, 46,5\% foram pegos por roubo, 15,2\%, por tráfico de drogas e 10,1\% por furto. Já na LA, 39,8\% haviam cometido roubo, 19,5\% tráfico de drogas e 10,1\%, posse ou porte ilegal de arma de fogo. Com relação à proporção dos gastos dos adolescentes, tanto na PSC como na LA o maior percentual vai para o gasto com "itens do vestuário". Gabriel, que conduz o trabalho de adolescentes em PSC em uma unidade executora desta medida, criticou o valor excessivo que os meninos dão a itens caros como tênis de marca e bermudas. Ele, inclusive, enfrentou problemas com um adolescente que não queria fazer o trabalho demandado no local onde Gabriel trabalha, pois não queria sujar o seu tênis: "o garoto que veio aqui na semana passada disse que tava usando um tênis de mil reais, não quis trabalhar para não sujá-lo”. Gabriel vê de forma negativa essa valoração que os adolescentes dão para roupas de marca, pois, segundo ele, isso seria uma futilidade e que se eles tivessem seu tempo ocupado com educação e esporte, gastariam energia e chegariam em casa só para dormir, e então iriam parar de pensar em futilidades, como comprar uma "bermuda nova de tal marca ou tal tênis da moda".

Sobre a renda familiar dos jovens em medidas no DF, a pesquisa da Codeplan mostrou que muitos adolescentes desconheciam a renda mensal total da família: 39,4\% 
na PSC e 33,6\% na LA a desconheciam. Na PSC, 63,4\% dos adolescentes disseram que a sua renda familiar mensal era de 1 a 3 salários mínimos. Na LA, esse número foi de 59,4\%. Na LA, $1 \%$ disse ser de até meio salário mínimo, e 13,8\%, de meio a 1; ao passo que na PSC não foi registrado nenhum caso de renda familiar inferior de até meio salário mínimo e o percentual de meio a 1 foi de 11,7\%. Na PSC, 10\% declararam renda familiar mensal de mais de 5 a 10 salários e na LA, esse percentual foi de apenas $5 \%$. No que tange à situação trabalhista dos adolescentes, na PSC, 25,3\% nunca trabalharam, 31,3\% já haviam trabalhado, mas não estavam trabalhando no momento da pesquisa, $25,3 \%$ estavam trabalhando no mercado informal no momento da pesquisa e $11,1 \%$ apenas estavam no mercado formal. Apenas 3\% disse estar fazendo estágio. Na LA, $36 \%$ já haviam trabalhado, mas não estavam trabalhando no momento, 23,5\% estavam trabalhando no mercado informal e $15,9 \%$ no mercado formal na época da pesquisa. $14,5 \%$ disseram nunca ter trabalhado e apenas 3,6\% se disseram estagiários. $0,9 \%$ do adolescentes em LA trabalhavam como "adolescentes aprendizes", uma iniciativa que normalmente é encorajada pela equipe técnica da UAMA, tal como observei, em especial para os adolescentes mais novos, que ainda não podiam ser contratados pelo mercado formal. No que diz respeito ao lazer dos jovens, destaca-se a preferência deles por "festas, baile funk, boate, frevo e afins" com 57,6\% na PSC e 56\% na LA. Cinema e shows vêm logo atrás como atividades de cultura e lazer que os adolescentes gostam ou gostariam de praticar.

A pesquisa investigou ainda o histórico dos adolescentes no que diz respeito à violência. As formas mais comuns de violência foram a física e a psicológica. A primeira foi citada por 55,8\% dos adolescentes em PSC e 57,6\% no caso da LA; já a segunda, foi mencionada por $17,2 \%$ na PSC e $16,4 \%$ dos adolescentes em LA. Os três motivos da violência sofrida mais citados pelos adolescentes foram conflito com a polícia, $38,4 \%$ na PSC e $37,1 \%$ na LA; conflito na escola, $24,2 \%$ na PSC e $17,3 \%$ na LA e; conflito entre gangues/grupos rivais, com $15,2 \%$ na PSC e $18,4 \%$ na LA. As sensações de segurança e de insegurança também foram dois fatores investigados pela pesquisa da Codeplan. No caso da PSC, 85,9\% citaram se sentir mais seguros em casa e $75,8 \%$, mais inseguros na rua; na LA, $88,2 \%$ afirmaram se sentir mais seguros em casa e $82,7 \%$, mais inseguros na rua.

Houve a investigação ainda das percepções dos adolescentes em MSE do DF sobre aspectos de sua vida a partir da identificação deles com algumas frases sobre 
plano de futuro, histórico sociofamiliar, experiência na medida que cumpre e percepções sobre saúde e educação.

De forma resumida, pode-se dizer que tanto os adolescentes que cumprem PSC quanto os que cumprem LA, veem-se tendo uma vida melhor em 10 anos, terminando o ensino médio em 5 anos bem como trabalhando e afirmaram que a família acredita que eles serão melhores após a medida, além de planejarem constituir família e terem planos para quando a medida acabar. A maior parte deles concorda com as afirmações de que tiveram uma boa infância e têm boas lembranças dos pais, que tem quem cuide deles em casa quando estiverem doentes e que já apanharam em casa. Por outro lado, nem metade (46,5\% na PSC e 45,3\% na LA) entende que a rua atrapalha que "mudem de vida". Cerca de apenas 30\%, nos dois casos, diz que estar em medida deixa a sua família envergonhada e que os problemas de sua família contribuíram para que estivessem em medida. Poucos disseram que em casa é normal acontecer agressão física e que já se sentiram rejeitados por suas famílias.

Sobre a experiência na medida, 91,9\% da PSC e 95,1\% da LA disseram que a equipe socioeducativa os incentiva a estudar e 90,9\% da PSC concordaram com a afirmação "cumprir essa medida faz com que eu reflita sobre meus deveres como cidadão". Para os adolescentes foi exposta a afirmação "é justo que eu pague pelo que eu fiz”, com a qual 88,9\% dos adolescentes em PSC concordaram e, em LA, 91,8\%. Com a frase "não é justo perder minha liberdade", 65,7\% dos adolescentes em PSC e $67,8 \%$ dos em LA concordaram. Sobre a tomada de decisões, $88,9 \%$ dos adolescentes em PSC e 93,8\% em LA concordaram com a afirmação de que o que os técnicos da UAMA dizem lhes ajudam a tomar decisões. Com a frase "quem cumpre medida, quando sai, volta pro 'crime"”, 47,5\% em PSC e 41,6\% em LA concordaram.

A respeito da saúde e da educação, 86,9\% de adolescentes em PSC e 92,4\% em LA concordaram que ir à escola pode mudar as suas vidas. Quase metade dos jovens das duas medidas afirmaram não gostar de estudar: 42,4\% na PSC e 43,6\% na LA. Poucos se disseram discriminados na escola por cumprirem medida socioeducativa: $5,1 \%$ na PSC e 5,6\% na LA. A maior parte deles disse ter bom relacionamento com os professores na escola: 56,6\% no caso da PSC e 54\% no caso da LA. Por fim, 41,4\% em PSC e 49,3\% em LA concordaram com a afirmativa "sou bem atendido nos serviços de saúde".

Após a apresentação do perfil dos adolescentes que cumprem medidas socioeducativas no Distrito Federal, cabe trazer também alguns dados mais específicos 
sobre os adolescentes atendidos na UAMA que pesquisei. A pesquisa a Codeplan entrevistou todos os adolescentes em Liberdade Assistida que estavam vinculados à Unidade na época das entrevistas. Do total, 57,1\% eram naturais do DF e 19\%, do Estado de Goiás, dado que difere bastante do percentual total para essa medida no DF, como pontuado acima. Os meninos representavam 76,2\% dos socioeducandos dessa medida na Unidade e as meninas, 23,8\%. O percentual de adolescentes que se declararam negros foi de 76,2\% e de não negros, 23,8\%. Esses dados são superiores ao percentual de negros no DF, que era de cerca 55\%, conforme relatório feito pela equipe técnica da Unidade pesquisada ${ }^{22} .47,6 \%$ dos adolescentes entrevistados tinham entre 17 e 18 anos de idade; 33,3\% afirmaram não seguir nenhuma religião, 38,1\% eram católicos e 28,6\% eram protestantes/evangélicos. A maior parte dos jovens relatou residir apenas com a mãe, $81 \%$, e serem solteiros, $85,7 \%$. 14,3\% viviam em união e $23,8 \%$ declararam ter filhos. $42,9 \%$ dos adolescentes da LA vinculados à unidade e entrevistados no âmbito da pesquisa supracitada informaram não estar estudando à época, ao passo que 47,6\% disseram que estavam matriculados e frequentando a escola. $52,4 \%$ tinha o ensino fundamental incompleto, fato que demonstra a defasagem escolar dos adolescentes, haja vista que a maioria já estava em idade compatível ao ensino médio para que estivessem em uma situação de idade $\mathrm{x}$ série recomendada. 9,5\% tinham ensino fundamental completo, $33,3 \%$ possuíam ensino médio incompleto e apenas 4,4\% já haviam completado o ensino médio.

No que diz respeito à Unidade, a taxa de reincidência dos adolescentes em LA entrevistados ficou em $23,8 \%$ e a maior parte deles informou ter de 1 a 2 passagens pelo sistema socioeducativo, sendo que $76,2 \%$ estavam em sua primeira passagem. Assim como nos dados mostrados acima referentes aos adolescentes do DF, também no caso dos adolescentes da UAMA que visitei, o principal ato cometido e que motivou a medida foi o roubo, o que, na Unidade, correspondia a $28,6 \%$ dos atos infracionais cometidos. A área que mais despertava o interesse dos jovens no que diz respeito à qualificação profissional era a de informática, com 38,1\%, seguida pela área de mecânica de automóveis, com 33,3\% e de eletroeletrônica, com 19\%. No que tange às atividades físicas, incentivadas pelos profissionais da UAMA, futebol, natação e artes marciais são as de maior interesse dos jovens.

\footnotetext{
${ }^{22} \mathrm{O}$ relatório a que me refiro é uma Nota Técnica produzida pela equipe da Unidade que visitei e que me foi disponibilizada e não se encontra publicada para o grande publico.
} 
Um pouco diferente do que visto acima para o DF, o percentual de adolescentes que disse se sentir seguro em casa é um pouco menor para o caso da UAMA visitada, $66,7 \%$, e menor também para a afirmação de que a rua é o lugar mais inseguro, com $52,4 \%$. Os percentuais referentes a um plano futuro ficaram, em geral, próximos dos percentuais gerais. Diferiu mais a porcentagem de adolescentes que concordaram com a afirmação "a rua atrapalha que eu mude de vida", sendo que na Unidade a taxa ficou em $33,3 \%$, mais de 10 pontos percentuais a menos que a taxa geral para o DF, de $45,3 \%$. Outro número discrepante é o do atendimento no serviço de saúde, enquanto no DF 49,3\% dos adolescentes em LA disseram ser bem atendidos nesse serviço, 71,4\% jovens da UAMA que visitei concordaram com esse afirmação. 


\section{CAPÍTULO 3 - O EX-SOCIOEDUCANDO CONVERTIDO}

Neste capítulo irei abordar um episódio que pude acompanhar na UAMA durante o meu trabalho de campo, a saber, a palestra de um ex-socioeducando, Rafael, para socioeducandos da Unidade e seus responsáveis legais, organizada pelas profissionais com a intenção de mostrar um caso positivo de mudança e trazer alguém que realmente falasse "a língua dos jovens". A palestra foi marcada para dois dias em turnos diferentes.

Rafael é um jovem de 23 anos com longa passagem pelo sistema socioeducativo, tendo "pego" todas as medidas cabíveis a adolescentes autores de atos infracionais. Passou por unidades de atendimento em meio aberto e pela internação. Após um fato marcante em sua vida, Rafael decide procurar a Igreja Adventista do Sétimo Dia e se converte. Passa a vender livros para conseguir dinheiro e investe na finalização de seus estudos de nível médio. Hoje Rafael é casado, tem duas filhas e faz faculdade de teologia na Argentina para voltar ao Brasil e exercer atuação de pastor. Toda vez que vem ao país, passa por unidades de meio aberto e também de restrição e de privação de liberdade para contar a sua história e convencer os meninos de que "o crime não compensa". Tudo isso, faz questão de ressaltar, "sem receber", mas porque tem "certeza de que a mudança é possível".

Descrevo e analiso abaixo o discurso proferido por Rafael aos meninos atendidos na UAMA onde conduzi a pesquisa, entendendo que ele se configura como um "testemunho" de sua vida e de sua mudança, que objetiva a motivar os adolescentes em seu percurso de "mudança de vida" e propagar sua ética religiosa como instrumento importante dessa mudança. Para evitar a repetição, descreverei prioritariamente o que vi no primeiro dia de palestra, em especial porque essa parecia bem ensaiada por Rafael, que seguiu um mesmo roteiro nos dois dias.

Ressalto algumas questões que merecem ser pontuadas, pois se relacionam à diferença do público do primeiro dia, em que a palestra ocorreu à tarde, e o segundo dia, em que esta ocorreu pela manhã. No primeiro dia, havia mais adolescentes e eles pareciam mais jovens. Havia pouco mais de vinte socioeducandos e cerca de oito responsáveis, mães, em sua maioria, mas havia um pai presente. Entre o socioeducandos, havia apenas quatro meninas, sendo o restante, meninos. Após o fim do evento, uma profissional disse ter avistado um menino que preferiu não entrar na sala alegando que "havia muita gente lá" e que preferiu ficar vendo TV em outro cômodo do 
CRAS. O fato foi comentado pelas profissionais, que afirmaram não entender por que o menino, que já havia se deslocado até lá só para participar da atividade, escolhera não adentrar a sala.

No segundo dia, em que a oficina ocorreu pela manhã, havia sete meninos e três meninas, um número menor de responsáveis legais, e os adolescentes pareciam mais velhos. Algumas profissionais comentaram que já esperavam mesmo um número menor no segundo dia de atividade, pois a maior parte dos socioeducandos convocados para essa data já estavam em acompanhamento, ao passo que no dia anterior a maior parte era composta por novos atendimentos e que esses jovens tenderiam a comparecer mais do que os que já estavam no sistema há mais tempo.

No segundo dia da atividade, a novidade foi Rafael ter levado um violão e tocado duas músicas de rap para os meninos, que dialogavam com a trajetória da dependência química e do apego a Deus para que mudassem de vida. Após o fim da atividade, pedi a Rafael que me passasse os nomes das músicas para que eu pudesse mencioná-las aqui, como farei adiante.

\section{1 - "SÓ EXISTE MUDANÇA SE VOCÊ ABRIR O SEU CORAÇÃO PRA ELE"}

No primeiro dia da atividade, cheguei ao auditório do CRAS, local onde a palestra ocorreu, pouco depois das 14 horas. Ao adentrar o local, vi a supervisora sentada em uma cadeira, explicando e tirando dúvidas acerca da "LA" e da "PSC" para os presentes, enquanto o ex-socioeducando e palestrante ainda não havia chegado. Após alguns minutos, outras pessoas chegaram e então veio o palestrante.

A supervisora à época, Letícia, apresentou o "ex-socioeducando" aos presentes e lhe deu a fala. Quando Rafael começou a falar, percebi que não parecia novo no negócio. Aliás, pouco depois ele comentou que trabalhava como vendedor de livros. Percebi que ele estava à vontade, tinha boa oratória e usava a linguagem dos adolescentes "em medida". Ele conseguia arrancar sorrisos, expressões sérias e gerar uma empatia quando contava a sua história e citava letras de rap. Os "meninos" pareciam, em diversos momentos, identificarem-se com as situações que relatava o "exsocioeducando". Era nítido como esse conseguira estabelecer um "diálogo" com os "meninos", mesmo que os moldes do evento não lhes dessem muito espaço para falar. Eles acenavam com a cabeça, cutucavam o colega e murmuravam falas do tipo "é assim 
mesmo"; "é desse jeito", parecendo-me que se viam nas situações que o palestrante lhes descrevia e que sabiam dos sentimentos que elas lhe haviam despertado. Quando cheguei, a supervisora explicava também sobre o PIA e ressaltava que as metas definidas para os adolescentes são avaliadas pelo juiz, que a equipe técnica "sugere" a liberação ou a permanência do adolescente na LA, mas que acabe ao juiz decidir sobre isso. Ela citou que as profissionais têm que ver que houve uma "mudança de vida significativa" para que haja a liberação do adolescente. "Vocês acham que a gente segura alguém aqui? Não, a gente não segura ninguém! $O$ relatório não é meu, é de vocês, diz respeito à vida de vocês". Pode-se ler essa frase na ótica da "responsabilização" que guia o serviço.

$\mathrm{O}$ palestrante Rafael chega à sala, senta-se e inicia a palestra. Ele começa dizendo que hoje ele tem "uma perspectiva completamente diferente" e que seu irmão está no presídio da Papuda. Durante o tempo em que ele cumpria medidas, que, no caso dele, envolveram várias internações e medidas em meio aberto, ele afirmou que sua família sofreu muito, em especial sua mãe. Rafael disse que "a gente se ilude com as coisas do crime". Ele pareceu conduzir a sua fala em torno da desconstrução dessas "ilusões do crime" e da ideia de que o "crime compensa". Primeiro, falou que a ideia que se tem acerca de suas amizades é errônea, que a frase "é "nóis' até o final" é uma grande mentira, pois no momento em que o "bagu fica doido", todo mundo "se manda". "Os nossos únicos amigos", diz, "são os nossos pais". Ele conta que quando estava "agonizando" após ser baleado, seus "amigos" debandaram e a única pessoa que ficou com ele até o final foi a sua mãe e não aqueles que o chamavam para "fumar um". Não, eles não estavam lá até o final.

Esse episódio em que foi baleado foi contado por Rafael também no segundo dia da oficina e parece ser um divisor de águas em sua vida. Tal como nos relatos que Eva Lenita Scheliga (2005) descreve de detentos que passaram por processos de conversão religiosa, é comum que se relate um momento de "crise", que é o que desencadeia uma "vontade de mudar" aspectos individuais e situações vividas. E o que parece ser uma coincidência entre mudança de vida e conversão religiosa não é de fato um evento fortuito.

Scheliga, que se debruça sobre processos de conversão religiosa em contextos prisionais, toma o processo de conversão religiosa como individualmente elaborado e como processo estratégico que "concede novos significados às práticas e, desta forma, altera as relações entre os diferentes grupos de detentos e destes com o mundo". (p. 75). 
Apesar de individualmente elaborado, entretanto, a autora entende o processo de conversão como compartilhado e estruturado socialmente e de forma singular no universo prisional. Scheliga retoma alguns relatos de conversão religiosa de detentos que são marcados por discursos de "crise", em que eles identificam o momento da prisão como o "fundo do poço" e se referem à conversão como o "retorno", sendo vista como uma "tomada de atitude" que dividiria os mundos e etapas de vida. O momento crítico no qual o processo de conversão religiosa teria sido iniciado, diz a autora, coincide muitas vezes com o momento da prisão. Para os detentos, a conversão religiosa surge como situação de aproximação dos familiares ou implica também a conversão religiosa de membros de sua família. Às vezes a situação de crise referente ao momento da prisão não é o "primeiro sinal da presença divina", mas é um momento crítico compreendido como situação em que se sente uma "força sobrenatural".

Nas palavras de Rafael, contudo, a conversão religiosa tem que ser verdadeira em alusão ao "cara que vive com a bíblia debaixo do braço quanto tá preso" e sai de lá e joga-a fora. Essa fala do ex-socioeducando é consonante com o que foi exposto por alguns interlocutores de Scheliga. Segundo exposto pela autora, há uma linha de raciocínio de pessoas que ela entrevistou que enxerga os detentos convertidos como que "se escondendo atrás da bíblia durante o cumprimento das sentenças". Esse raciocínio veria as conversões dentro das prisões como estratégia de alguns detentos para "enganar" ou suprir carências, significando a salvação do convertido em relação aos perigos produzidos na situação de encarceramento, como acertos de contas, humilhações, privações materiais e da intimidade, abusos de autoridade por parte de funcionários e outros detentos.

Entretanto, segundo os convertidos entrevistados por Scheliga, a conversão, quando se efetua de fato, sempre produz mudanças, especialmente porque quase todos os "testemunhos", diz a autora, iniciam-se com a conceituação da conversão religiosa como sendo ela própria uma mudança. Os testemunhos, comenta Scheliga, seriam momentos privilegiados de transmissão de saberes e de uma ética religiosa. Como lembra a autora, a tradição protestante prevê a possibilidade de que qualquer fiel possa se transformar em um anunciador do discurso religioso, o que, entendo, foi feito por Rafael durante a oficina que acompanhei. Entretanto, para que se torne um anunciador oficial do discurso de sua Igreja, Rafael pontua a necessidade de formação acadêmica em teologia, curso que ele estuda na Argentina, com o objetivo de voltar ao Brasil para atuar como pastor. 
O "ex-socioeducando" prossegue com a segunda desconstrução que ele buscou fazer em seu discurso aos adolescentes, que diz respeito ao que ele chamou de "glória" do crime. Segundo ele, essa glória e reconhecimento que se pensa que o crime dá não passa de mais uma mentira que "alimenta o coração do malandro", que pensa que um dia "vai chegar lá, mas isso nunca acontece". Quando o "malandro" passa pela "rua" e os outros abaixam a cabeça, ele se sente o "tal", mas, alerta o "ex-socioeducando", não se trata de respeito e sim de medo. Ele alerta que as coisas não acontecem como no DVD do $50 \mathrm{Cent}^{23}$, que eles veem uma casa com piscina, "mulherzona", nem nada disso. A "real" é que "vocês bebem Whisky e Red Bull no 'frevo', mas voltam 'pras quebradas' e tomam pinga, qualquer coisa".

Nesse momento, os jovens riem e fazem comentários. "E assim vai", ele diz, “começam tomando 'birita' cara e depois acabam tomando pinga!". Ele fala: "vocês acham que um dia vão conseguir isso aí no crime, casa, carro caro, eu nunca ganhei nada". "Além disso", continua, "é algo amaldiçoado, porque não ganhou com seu esforço, seu trabalho". E”, diz ele, "em algum momento você vai cair, como é que eles dizem? Um é considerado e outro é o quê?”. Nesse momento é possível escutar alguns completando a frase do palestrante. Juntos, eles dizem "tirado", e o ex-socioeducando repete: "isso mesmo, um é considerado e o outro é tirado". Segundo ele, o crime sempre "cria coisas para dividir os caras" como aquele que usa crack versus aquele que usa cocaína, apontando para um contrassenso nesse tipo de divisão, haja vista que ambas as drogas são feitas de uma mesma pasta base e que os dois caras, tanto o que usa crack quanto o que usa cocaína vivenciam situações complicadas e "ficam lá babando". Ele diz que um dia "tava lá batendo na cara do drogado" e "tirando onda", mas lembra: quantas vezes ele próprio não acordou na DCA sem nem mesmo saber o ato que havia cometido? Os meninos esboçam alguns risos. Mas então o clima fica mais sério quando o palestrante diz que "quem tá embaixo pode um dia ir para cima e quem tá em cima um dia pode estar embaixo" e quando fala que se o "malandro fizer a soma para ver se o crime compensa, se ele fizesse a soma, ele veria que não compensa".

Assim, conforme compreendi a atuação do ex-socioeducando Rafael na UAMA, a palestra oferecida por ele na Unidade parece ser um desses casos de "testemunho",

\footnotetext{
${ }^{23}$ Rapper norte-americano cujo um dos álbuns que o levou à fama se chama "Get rich or die tryin"” e que exibe em seus clipes carros luxuosos, mansões, correntes de ouro, festas caras, notas de dinheiro e se apresenta rodeado por mulheres. Nos clipes também é comum a exibição de consumo de álcool e outras drogas e a referência a crimes e a contextos violentos e pobres. O rapper esteve ele próprio envolvido com o tráfico de drogas quando adolescente e sobreviveu a um episódio em que foi baleado nove vezes, no ano de 2000, pouco antes de sua carreira de músico deslanchar.
} 
lido como momento privilegiado de transmissão dos saberes e de uma ética religiosa. Ao dar o seu testemunho sobre como mudou de vida, parou de usar drogas e de cometer atos infracionais, além de ter voltado a estudar e estar fazendo faculdade, Rafael transmite aos jovens que o assistiam uma ética religiosa que ele adotou para si e que agora divulga por meio de palestras para jovens que cumprem medidas socioeducativas em meio aberto, em semi-liberdade e na internação.

"Daí", continua o palestrante, "você pergunta pro cara por que ele roubou, aí ele diz que rouba porque não tem a roupa que quer, porque a mãe tá doente e não tem como comprar o remédio e eu digo 'por que não vai trabalhar?"'. Fazendo paralelo com a ética protestante estudada por Weber (2004), a falta de vontade de trabalhar, nessa perspectiva, poderia ser entendida como sintoma de estado de graça ausente.

Em vários momentos da palestra, ele faz alusão a letras de Rap, uma delas fala dos "malandros" como aqueles que "decidem viver pouco como reis a viverem muito como zés". Mas o "ex-socioeducando" afirma que as coisas na vida real são mais complicadas, que a coroa de rei que eles vão ganhar é uma "coroa de bala" e que "malandro mente muito". Ele próprio, quando estava internado, falava aos outros internos que saindo da internação resgataria a "sua grana enterrada", mas nunca teve "grana nenhuma enterrada".

Mais uma vez o tema trabalho é abordado: "malandro não quer trabalhar porque diz que não dá em nada, que os caras trabalham e não têm nada, mas o que eles têm? Também não têm nada! Acho isso engraçado". Fala da sua trajetória e da trajetória daqueles com quem conviveu: "começa fumando um cigarro, maconha, tomando 'birita', daí abandona o colégio e o trabalho e daí pra frente só se afunda”. Sempre desconfie daquele que "te chama pra fumar um, tu pode ir e nem voltar mais".

O discurso positivado de Rafael acerca do trabalho pode se inserir na lógica protestante analisada por Weber (2004), por oposição à exibição de bens materiais e mundanos caros, como carros, casas com piscina, "whisky e Red Bull”. Segundo Rafael:

O cara quer ser reconhecido, quer respeito da quebrada, porque anda armado, quer a glória. Depois o cara compra um carro e uma moto, mesmo que velho, e já é invejado. O cara do crime quer ostentar.

No que se refere à ostentação, Rafael menciona também as roupas, como elemento material que é considerado pelos jovens. A ostentação desses bens, conforme a doutrina protestante tradicional examinada por Weber, não condiria com uma vida 
ascética e, conforme nos falou o referido autor, uma das metas da ascese protestante era eliminar a espontaneidade do gozo impulsivo da vida, botar ordem na conduta de vida de seus seguidores, o meio mais importante da ascese.

Assim, quando falo em Rafael enquanto ex-socioeducando convertido, refiro-me não só à sua conversão religiosa, mas também à sua conversão no sentido de mudança de atitude perante a sua vida, em especial por ter saído de uma trajetória de vida marcada pela violência e pelo cometimento de atos infracionais. Essa mudança seria, como mostrou Weber, efeito que a apropriação subjetiva da religiosidade ascética por parte do indivíduo suscitaria na conduta de vida (WEBER, 2004, p. 137).

Ainda de acordo com a referida ética religiosa, é condenável o gozo da riqueza com sua consequência de ócio e prazer e o descanso sobre a posse, descanso este que é do Outro Mundo. Na terra, o ser humano deve buscar a certeza do seu estado de graça, por isso o entendimento do ócio e do prazer enquanto perda de tempo, sendo esta o mais grave de todos os pecados. O tempo, nessa lógica, é valioso, e cada hora perdida é trabalho subtraído ao serviço de glória de Deus (Idem, p. 143-144).

A utilidade da profissão do agrado de Deus se orientaria por critérios morais, pela importância para a coletividade dos bens que serão produzidos nela e a sua capacidade de dar lucro, lucro econômico privado (p. 148). Nessa perspectiva, é permitido trabalhar para ficar rico. Quando a riqueza advém de desempenho do dever vocacional, ela não é só moralmente lícita, mas até mesmo um mandamento. Este ganho só não deve ser usado para "fins da concupiscência da carne e do pecado" (Ibidem, p. 148).

Quando Rafael fala de sua internação no CAJE, cita os casos em que os internos "xingam a mãe" de outros internos e como isso reverbera de maneira violenta naquele espaço: "lá dentro dizem que amam a mãe, matam quem fala mal da mãe, mas se amasse mesmo a mãe não tava ali dentro". Uma mãe presente diz: “é isso mesmo! É muita humilhação que a gente tem que passar!”. Em diversos momentos, Rafael diz: "eu acredito na mudança", "eu acredito em vocês". O vício nas drogas e a ideia de que “todo mundo saiu correndo na hora do 'bagu' doido" é também abordada por ele algumas vezes.

Quando ele agonizava no asfalto após ser baleado, ele lembra que a única pessoa que ficou ao seu lado foi a sua mãe. Traz a importância do papel da mãe na vida dele, mais uma vez, e o evento que o marcou: de ter sido baleado, quase morrido e ido para o Hospital de Base. 
Graças a Deus eu já tava preso aos 16 anos, porque se tivesse solto, eu estaria na Papuda hoje.

Comenta que quando saiu da internação e após passar pelo trauma do momento em que foi baleado, percebeu que sua mãe era sua única amiga e começou a se engajar na religião e no trabalho. Quando chegou ao local de uma construção para trabalhar como pedreiro, ele disse que o "diabo" já veio lhe falar novamente e "pensamentos malignos" vieram à sua cabeça: "eu não vou passar o dia no sol quente trabalhando pesado para ganhar 40 reais por dia”. Mas ele ficou e passou a ganhar mais e a ocupar cargos mais altos dentro do ramo da construção, então, disse ele, viciou-se nessa "coisa de ir ganhando dinheiro assim".

A retórica do trabalho pesado e da conquista paulatina dos bens materiais, contudo, foi exposta de outra forma por Rafael nos bastidores de sua palestra. Quando já estávamos na sala das técnicas da UAMA, só os funcionários, eu e ele, pedi uma entrevista com Rafael. Foi nesse momento em que ele afirmou que, em realidade, logo largou a construção civil para vender sorvete, pois percebera que seria algo mais rentável e enfatizou o quanto foi dura a sua trajetória.

No que tange à imagem do diabo evocada para se falar de momentos em que as atitudes do convertido seriam "reprováveis", Côrtes (2007), ao estudar casos de conversão religiosa de presidiários e ex-presidiários ao pentecostalismo e neopentecostalismo, afirma que esta imagem acaba por "vitimizar" os convertidos mais do que responsabilizá-los por atos que seriam ética e moralmente "errados". A autora faz um corte entre o ethos protestante tradicional, no qual se insere Rafael, por exemplo, e o ethos das Igrejas neopentecostais. Tal como entende a autora, a saída encontrada por pessoas que tinham carreira criminosa ao procurar a conversão religiosa e a carreira de pregador, que ela analisa em seu livro, não é uma alternativa moderna no sentido clássico, pois não aposta na transformação do homem nem pela sujeição disciplinar do corpo e nem por sua emancipação política, se lembrarmos das reflexões Foucaultianas e Marxistas, respectivamente. Trago algumas considerações feitas por Côrtes, haja vista que dialogarão com a trajetória de vida e com a perspectiva de Rafael sobre o sistema socioeducativo e com o próximo capítulo, em que discutirei valores da modernidade ocidental que estão subjacentes às diferentes visões sobre as MSE que encontrei em campo.

Mariana Côrtes (2007) discute a modernidade e como o contexto social, histórico e econômico se relaciona com a religião e os processos de conversão. Ela se 
refere a duas etapas da modernidade: uma modernidade pesada e uma modernidade leve ou líquida, nos termos de Bauman. A cada etapa da modernidade ela atribui um tipo de ética religiosa. Na primeira etapa da modernidade, haveria uma ética religiosa mais firme, ancorada em preceitos éticos e morais mais rígidos, em que para que se operasse a conversão religiosa era necessária a admissão de uma culpa, a confissão dos pecados e uma tomada de consciência em que o novo fiel percebesse o caminho errado que sua vida estava tomando e então o alterasse.

Por sua vez, no tipo de modernidade contemporânea, em tempos de acumulação flexível do capital, em que a autora menciona também o declínio da importância das instituições, como a família e a religião, existiria uma lógica menos disciplinar do Estado e mais neoliberal, e as igrejas pentecostais e neopentecostais não buscariam, ao contrário da fase anterior, um sentido unitário para vida, e teriam substituído a noção de culpa e de consciência por uma retórica que afirma a existência do diabo e o utiliza como explicação para más condutas passadas, sem contudo, reafirmar um discernimento entre o certo e o errado por meio da ética e da moral, diferente do que faz Rafael durante a oficina, em que afirma que não existe "relatividade". Segundo ele:

No mundo hoje tudo é muito relativo, sou casado, mas hoje parece que se sou casado ou não tanto faz. É difícil enxergar uma linha só no meio de muitas. Existe sim uma conduta errada, não existe relatividade. A relatividade ajudou a desenvolver o pensamento crítico, mas também bagunçou as coisas! Devemos achar a conduta correta em Deus.

Por outro lado, o discurso pentecostal da ação do demônio na vida das pessoas, trazido por Côrtes, ao invés de culpabilizá-las por seus atos passados ruins, discernindo entre certo e errado, vitimiza-as como tendo sido possuídas.

As igrejas evangélicas não buscam, como exposto por Côrtes, o combate de práticas violentas de forma direta e política. Também não buscam padrões de equidade e justiça coletivos. Ao invés disso, apostariam na retomada de uma experiência voltada para assuntos individuais, privados e domésticos e distanciada dos problemas coletivos mais amplos. Dessa forma, argumenta a autora, a premissa fundamental é a de que o mal não reside nas injustiças da sociedade, mas nos indivíduos em cada um deles e de cada um deles deve ser extirpado por meio dos rituais de exorcismo e libertação.

A autora diz que, portanto, não se aposta mais no adestramento dos corpos por meio disciplinar, e nem em um engajamento político por uma sociedade melhor. Ela identifica o declínio das promessas do projeto clássico da modernidade, o que teria 
aberto espaço para a expansão de outras soluções, que depositam sua fé numa transformação mágica repentina, operada no plano espiritual imediato pelo poder de Jesus Cristo e do Espírito Santo na realização de milagres.

Ao contrário, como faz questão de ressaltar Rafael, sua religião é algo lógico, racional e não tem magia. Essa afirmação nos remete ao protestantismo clássico, como nos fala Weber (2004), que repudiavam os meios mágicos de busca da salvação: "não havia nenhum meio mágico, melhor dizendo, meio nenhum que proporcionasse a graça divina a quem Deus houvesse decidido negá-la" (p. 96). Nesse sentido, o trabalho social no mundo é exclusivamente trabalho para aumentar a glória de Deus, por isso, o trabalho numa profissão que está a serviço da vida intramundana da coletividade também apresenta esse caráter. $\mathrm{O}$ amor ao próximo, característico do sistema ético calvinista, por exemplo, expressa-se em primeiro lugar no cumprimento da missão vocacional-profissional e nisso ele possui um caráter peculiarmente racional do cosmos social que nos circunda (p. 99).

O processo de secularização e a emergência da modernidade, conforme nos lembra Côrtes (2007), fez com que a religião perdesse a sua capacidade em fornecer fundamentos ético motivacionais para a ação dos indivíduos e também a sua função de integração social. Ela ainda nos fala que o processo de racionalização religiosa eliminou os elementos mágicos da religião fornecendo uma racionalização teórica que confere um sentido unitário e coerente para o mundo; por outro lado também houve uma racionalização prática que orienta e informa aos agentes sua conduta ética cotidiana, como ficou claro no discurso de Rafael.

Resgatando Weber, a autora lembra que a modernidade também clamou por uma teodiceia, que, nos termos daquele autor, seria uma resposta ética fundamental capaz de oferecer uma justificativa racional para a desigualdade na distribuição dos bens (materiais e simbólicos) entre os homens e responder por que uns têm mais do que os outros (p. 32). O surgimento das cidades, e a "individualização do sofrimento" que veio com ele, forneceu as condições externas para o processo de racionalização religiosa e esta, por sua vez, também ofereceu condições internas necessárias para a emergência da modernidade.

Retomando Weber, Côrtes afirma que ainda que a universalidade do amor da ética da fraternidade tenha contribuído para o aparecimento do capitalismo, a sua consolidação só foi possível graças a uma alternativa, a ética protestante, que resolveu a tensão instaurada entre religião fraternal e mundo econômico racionalizado. 
Mariana Côrtes lembra que o puritano ascético descrito por Weber estava preocupado em provar para si mesmo que era um eleito. Assim, ele não queria trabalhar para ficar rico e fruir o status adquirido, mas para que o êxito profissional fosse um signo externo que desse mais segurança de que era um agraciado e de que seria salvo. Foi a busca por essa certeza de salvação que proporcionou a metodização da vida por meio do exercício sistematizado e centrado da profissão e do controle dos impulsos e dos afetos.

Como o fiel, neste caso, não tinha tempo para se ocupar do sofrimento alheio, pois estava preocupado em garantir a segurança de que seria o eleito, tendo renunciado, assim, o puritanismo ao universalismo do amor e racionalizado o trabalho como "serviço à vontade de Deus" e "comprovação do estado de graça", estabeleceu-se a conexão de sentido entre "ética protestante" e "espírito do capitalismo" (p. 35-6) ou, como se diz, uma afinidade eletiva. Conforme nos lembra Côrtes, foi a metodização da vida, promovida pela ética profissional do protestantismo que significou o ponto de partida para a consolidação da sociedade capitalista.

Essa reflexão seria uma porta de entrada para pensarmos no que guia a conduta e os comportamentos dos fieis convertidos. Em vários momentos, Rafael traz em seu discurso a retórica da valorização do trabalho e enfatiza o seu "sofrimento", "trabalho pesado", por oposição ao "malandro", que prefere roubar e "fumar as suas oportunidades", ao invés de aproveitá-las.

Segundo argumenta Côrtes, a salvação religiosa oferecida pelas denominações pentecostais e apresentada aos sujeitos que tiveram experiências criminosas em suas trajetórias não é moderna, no sentido clássico, pois não reproduz a "conexão entre disposição religiosa racional e mundo moderno", como ocorreu historicamente nos países centrais do Ocidente. Ela identifica a inoperância de formas seculares e laicas de "salvação" e de transformação para os sujeitos envolvidos com práticas violentas, como a reforma disciplinar, a emancipação política ou a participação no espaço público (p. $37)$.

Côrtes resgata ainda uma breve comparação entre a realidade brasileira e a norteamericana, segundo alguns autores. Citando Sergio Buarque De Holanda e Jessé de Souza, em diálogo com Weber, ela fala em uma "mentalidade brasileira" como sendo avessa à mentalidade protestante do empreendimento voluntário, o associativismo e planejamento racional, características dos Estados Unidos e que teriam feito daquele país uma grande potência econômica, nação, aliás, onde foi fundada a Igreja Adventista 
do Sétimo Dia, a qual pertence Rafael, e que mais tarde negou o movimento pentecostal.

Ao invés disso, no Brasil, seríamos orientados por relações emocionais e imediatas com sujeitos das relações sociais primárias, o que seria próprio de nossa formação patriarcal e um obstáculo à constituição das instituições modernas e o mercado racionalizados, necessariamente orientados por relações impessoais (p. 37). Assim, o tipo ideal do homem-cordial teria como contraponto justamente o tipo-ideal do puritano ascético. O segundo planejaria suas ações tendo em vista resultados em longo prazo, controlando com rigor os seus afetos, ao passo que o segundo agiria de acordo com exigências do imediato, pensando no curto prazo, sem estabelecer controle dos seus afetos. Essa afirmação, entretanto, como nos alerta Côrtes, não deve ser vista enquanto uma hierarquização entre como a modernidade se deu na Europa e Estados Unidos e aqui no Brasil, apenas alerta para o fato de não se entender o paradigma Weberiano do racionalismo ocidental como referência absoluta.

A ética protestante tradicional da disciplina ascética e individualizante, de controle dos impulsos e paixões, não parece possuir eficácia diante da experiência de indivíduos seduzidos pelas promessas e eventuais benesses da sociedade de consumo, pela afirmação sem limites do poder da arma, pelo dinheiro pela disposição para matar, envolvidos por relações sociais em que as éticas vocacionais são declinantes. Diante de tal experiência de mundo, as estratégias do movimento pentecostal parecem ter maior eficácia. (p. 39)

As igrejas neopentecostais, afirma Côrtes, se acomodam ao mundo do consumo e reformulam a ética protestante tradicional fundando a chamada "Teologia da prosperidade". Na primeira e tradicional, a prosperidade pecuniária viria pela combinação da disciplina ascética e penosa do trabalho com a contenção de gastos mundanos. Por outro lado, na fórmula pentecostal, há uma inversão da ética do trabalho. $\mathrm{Na}$ Teologia da Prosperidade, ao invés da frugalidade, há a fruição, o adepto adquire prosperidade material intencionalmente, mediante uma barganha com Deus, exigindo deles as bênçãos a que julga ter direito (p. 41)

Assim, o ponto crucial que, segundo Côrtes, diferenciaria as duas éticas é que na tradicional, a solução para todo mal se dá pela conduta rígida e moral, ao passo que na lógica pentecostal, ela se daria pela expulsão dos demônios, origem de todos os males. Assim, há a retomada da magia como elemento imediato de salvação.

Os grandes centros urbanos latino-americanos, lembra-nos, são diferentes dos centros urbanos europeus e norte-americanos, locais da "pontualidade", 
"previsibilidade", "exatidão". Ao contrário, diz, em países como o Brasil, essas características se tornaram mais "fábulas a se perseguir, na tentativa de superar o estigma de atraso, do que realidades concretas e palpáveis", faltando uma "consciência de modernidade". Ela diz ainda que isso não significa que não tenhamos nos modernizado, mas grandes contingentes da população ficaram à margem do projeto modernizador. Na sociedade brasileira, comenta:

o homem comum e pobre não incorpora a ética individualizante do cálculo racional, mas é obrigado a lidar, a todo momento, sobressaltado, com irracionalidades e contradições da implantação estrangeira de uma 'modernidade anômala', conforme expressão de José de Souza Martins (2000, apud Côrtes, 2007, p. 43).

A autora prossegue:

Essa experiência em grande parte instituinte da constituição moderna em países periféricos, é radicalizada em tempos atuais, em que qualquer promessa de modernidade promissora e altaneira oferecida a todos, ainda que 'postiça', foi definitivamente desesperançada na vigência contemporânea das estratégias liberais e na exacerbação da desigualdade social (p. 43).

Por fim, resumindo a condição em que se encontram os homens convertidos às religiões pentecostais e neopentecostais no Brasil e, de forma geral à camada mais vulnerável de pessoas, que ficaram à parte de uma modernidade prometida, a autora afirma:

A experiência cotidiana da imprevisibilidade, que atinge os homens comuns e pobres, sobressaltados com o modo de vida urbano 'anômalo' das grandes cidades do capitalismo periférico, é, em muito, exacerbada e maximizada na experiência dos sujeitos envolvidos com as práticas, perspectivas e carreiras do 'mundo do crime', em que a não-antecipação ao risco e ao imprevisto eminente redunda, muitas vezes, em morte certa. Nessa experiência, a imprevisibilidade ganha, frequentemente, o sentido objetivado do medo e da desconfiança de todos (p. 45).

Sobre a UAMA, Rafael diz: "possibilidade de consertar a sua vida é agora nesse lugar". "Aqui na UAMA a minha vida foi encaminhada". Ele fala que os meninos tiveram sim oportunidades, mas que "eles enrolaram elas e fumaram, elas viraram fumaça", que a oportunidade eles "colocaram no pente de uma arma e foram assaltar alguém" e que eles devem ser otimistas, porque o otimista, diante da dificuldade, encontra oportunidade. Disse que eles não têm o que fazer, "daí vão arrumar 'guerra"”.

Fala que quando esteve internado, ele sabia a hora de sair quando era liberado e para onde não ir. "Se eu moro aqui e tenho guerra em Samambaia, o que eu vou fazer 
lá?" Exemplificou. Ele disse que os "meninos" têm que "pensar". Por exemplo, cita os momentos em que ele podia sair da unidade de internação e como eles às vezes postergava a sua saída de propósito para se certificar de quem ninguém estaria esperando por ele lá fora, pois ele tinha "muitas guerras" em muitos locais. Então ele diz: "vocês têm que pensar! Mas não, o malandro sai mesmo assim, porque ele é rueiro. Vocês têm que pensar". Essa fala coloca a questão da exposição aos riscos que os territórios onde eles têm rixas representam à vida deles e que, por isso, eles têm que saber a hora de ir para a "rua" e para onde não ir, evitando ir para certas "ruas", apesar de essa vontade de estar na rua, de ser "rueiro", como ele diz, parecer falar mais alto. Algumas vertentes do protestantismo tradicional, conforme nos lembra Weber, enfatizam a "ponderação serena da ação, orientada por um cuidado exame da consciência individual", exposta por Rafael como essa noção de que "o cara tem que pensar".

A partir do que foi dito acima, fica explícito como Rafael elabora o seu discurso para construir o trabalho como algo que recompensa e que é verdadeiro frente às mentiras e perigos do crime, que levam o malandro à morte e não lhe dão o que é prometido. Em vários momentos, usa as letras do rap para se expressar e mesmo desconstruir as idealizações das letras de rap e as imagens que elas constroem, a exemplo daquele de que o "malandro" é rei e detentor de prestígio e bens materiais caros. Quando começou a "mudar", ninguém das "quebradas" dele acreditava, e ele então começou a voltar para lá com as roupas bem sujas do trabalho na obra para mostrar que estava trabalhando. Segundo ele, a "sociedade não vai acreditar que você pode mudar o seu comportamento", por isso, quando se inseriu no trabalho de vendedor de livros, poucos criam no que viam.

Sobre esse momento de sua vida, ele conta que certa vez foi vender livros na rua dele e onde ele já havia praticado atos. Uma senhora o reconheceu e fechou a porta na cara dele, outra a recebeu e quando perguntou por que ele vendia livro ele disse que queria estudar. A senhora, curiosa, perguntou o que ele estudaria, e ele disse que não sabia. Ela indagou: "como não sabe, tá aqui no sol quente vendendo livro todo dia e não sabe o que quer estudar?" Então ele, tímido, disse que queria ser pastor e ela "falou um monte para ele", gritou, e segundo ele, com razão, afinal, "como acreditar em alguém que até ontem praticava esses atos e hoje quer ser pastor?”. A senhora resolve, então, que Rafael deveria começar a sua vida mudada por pedir perdão a alguém que ele 
havia prejudicado. Ela então o fez ir até um mercado próximo, onde ele havia cometido tentativa de latrocínio contra o dono e sua família e pedir desculpas.

Rafael descreve que foi até o mercado junto com a senhora muito receoso de que o dono do mercado tentasse alguma represália contra ele. Ao invés disso, e para a surpresa de Rafael, o dono do mercado, ao vê-lo, chorou. Essa não era a reação que ele esperava do comerciante. Inclusive, Rafael disse que "com sua mentalidade de malandro", fez o percurso até o mercado se preparando mentalmente para fugir caso a situação pusesse a sua vida em risco, o que, aliás, ele viu com naturalidade e disse que aquele homem tinha "todo direito de querer mata-lo". Entretanto, o comerciante chorou ao vê-lo dizendo que aquele que ali entrara em seu mercado não era mais o mesmo menino que havia cometido o crime que traumatizou a sua família havia três anos. "O tempo passa e você pode mudar", disse Rafael. "A mudança não é de farsa, é de verdade", completou. O senhor dono do mercado o perdoou, vendo nele uma pessoa diferente quando ele adentrou o local onde praticou o ato três anos depois. A partir desse relato do perdão obtido pela pessoa que havia lesado, Rafael retoma a ideia de que a UAMA seria o lugar para "direcionar a vida dos adolescentes", e que isso só dependeria deles.

“Errar”, diz Rafael, “é humano”. "Está tudo nas suas mãos”, completa o jovem. "O respeito", diz ele aos adolescentes, "tu vai conseguir quando tu vencer e sair dessa vida". O ex-socioeducando menciona a "atitude" que os meninos tiveram que ter para entrarem no crime e que é essa mesma atitude que eles devem usar para sair dele.

Weber (2004) ao analisar a ética protestante, em termos práticos, afirma que nessa perspectiva o que se entende é que "Deus ajuda a quem se ajuda" e, por isso, o calvinista, por exemplo, "cria" ele mesmo a certeza de sua "bem-aventurança eterna", consistindo essa em criar numa auto-inspeção sistemática que, na verdade, a cada instante enfrenta a alternativa: eleito ou condenado? (p. 105), sendo esta a grande questão que mobiliza o protestante.

Outro elemento forte acessado por Rafael para convencer e motivar os jovens a interromperem suas trajetórias de cometimento de atos infracionais é a dimensão da "vergonha" que a família sente e como estar "focado na família" reverte em menos risco para os jovens, pois uma vez que ele é identificado por quem tem rixa com ele como "focado em sua família", entendia-se que não se havia mais motivo para arrumar "guerra com ele". Mas Rafael alude à dificuldade que é mudar. Como ele diz "Tu pensa que as coisas são mágicas, mas não são", "tem que lutar muito". Nessa luta, o poder da 
Igreja e de Deus seria essencial para dar força para mudar. Diz Rafael: "a quadrada [pistola] já falhou, a bíblia nunca falhou e ainda te defende. Seja malandro, sai dessa vida".

Ao final da atividade, Rafael pediu para cada um falar o que queria ser. A maioria disse que não sabia ou que não queria falar. Um jovem disse que gostaria de se químico, alguns mencionaram "jogador de futebol”. Outro disse ainda "o exemplo da minha família". Rafael encerrou a atividade dizendo "que Deus te abençoe e te guarde! Existe perdão pra você, está tudo nas tuas mãos!"”. A supervisora Letícia diz aos jovens em seguida: "espero que sirva de reflexão para vocês. Quem não tem um sonho ou vislumbra algum futuro agora é a hora de começar a sonhar um futuro melhor 'pra' sua trajetória".

Por fim, lembra o palestrante, "no socioeducativo não tem o raio-x", em alusão à fala da mãe que comenta a humilhação da revista pela qual tem que passar quando visita o filho na cadeia. "Nem todos têm o privilégio de estar aqui hoje, só existe mudança se você abrir o seu coração 'pra' Ele”.

Após o término da atividade, houve muita conversa sobre a questão da mudança de gestão: questões de assinatura, a saída da supervisora, que iria em breve para uma unidade de internação, a chegada da nova supervisora, troca de Secretária da Secretaria da Criança, a troca do coordenador das medidas de meio aberto.

A palestra do dia seguinte estava marcada para às 10 horas da manhã, horário em que chegou o palestrante e ex-socioeducando Rafael, trazendo consigo, desta vez, um violão. No dia anterior, ele havia dito que gostaria de cantar e tocar umas músicas, mas as profissionais não conseguiram o violão. Na quarta-feira, ele levou um. A atividade começou por volta das $10 \mathrm{~h} 15$, com a explicação da supervisora de que esse momento coletivo deve ocorrer todo mês, mas que não exclui os atendimentos individuais dos adolescentes na Unidade. Comenta ainda da importância de os adolescentes irem à Unidade para acompanhamento. Supervisora apresenta o ex-socioeducando, fala que se trata de trabalho "voluntário" dele, "ele não ganha nada para estar aqui hoje falando pra vocês". Diz que "hoje ele tem outra trajetória de vida". Palestrante toma a palavra e diz que faz o que faz "porque acredita que a mudança é possível". Conta que ficou no "sistema socioeducativo" de 2007 a 2011. Começa, como no dia anterior, por falar de todo o sofrimento que sua família, em especial a sua mãe, tiveram em virtude disso. Disse que seu pai "saiu fora faz tempo" e sugere tocar no violão um "rap das antigas, que com certeza todo mundo conhece". Trata-se da música chamada "depoimento de 
um viciado", do grupo "Realidade Cruel”. Segue a letra ${ }^{24}$, que foi integralmente cantada por Rafael:

São duas da manhã e eu de calça e blusa

O tempo frio, do céu cai chuva

Eu sou sozinho, parceiro, e é foda

Com meu destino ninguém mais se importa

Chegar ao ponto que eu cheguei é lamentável

Estado físico inacreditável, eu sinto crise

Eu sinto convulsão, é muito triste o meu estado, sangue bom

Trinta quilos mais magro, vai vendo

O resultado é pura essência do veneno

O vício tira a calma, a cabreragem [medo] me acelera

O demônio rouba a alma, o inferno me sequestra

Cadê a luz que vem lá do céu?

Cadê Jesus pra julgar mais este réu?

Tenho vontade de morrer constantemente

O descontrole da mente me deixa impaciente e é foda

Eu saio que nem louco pela rua

Único mano é o cano na cintura

Eu preferia tá falando de amor

Falando das crianças e não da minha dor

Mas eu sou o espelho da agonia de um homem

Sem identidade, caráter, sem nome

Sem Mercedes, Audi ou Mitsubishi

Consumidor da praga do apocalipse

Tão jovem, sem esperança de vida

Tão novo e já suicida

São duas da manhã e faz chuva

$O$ pesadelo ainda continua

Um dia frio

Um bom lugar pra ler um livro

E o pensamento lá em você

Eu sem você não vivo (depoimento de um viciado)

Um dia frio

Um bom lugar pra ler um livro

E o pensamento lá em você

Eu sem você não vivo (depoimento de um viciado $)^{25}$

Comecei de forma curiosa

Um cigarro de maconha não era droga

Era o que todo mundo me falava

Experimentei, nem eu mesmo acreditava

Primeira vez, outra sensação

Segunda vez, mó barato, ilusão

Mundo dos sonhos, me sinto mais leve

Enquanto isso, os meus neurônios fervem

Sentia fome, sentia a viagem inteira

\footnotetext{
${ }^{24}$ Disponível em http://letras.mus.br/realidade-cruel/67956/, acesso em 12 de maio de 2015.

${ }^{25}$ Esses dois trechos pertencem à música "Nem um dia" do cantor e compositor Djavan, mas aqui, como entendo, foram usadas como um recurso do grupo Realidade Cruel para falar do vício nas drogas, em que o "você" se refere à droga.
} 
Observava de longe as paisagens

A fumaça me deixava cada vez mais louco

Sem perceber eu já era o próprio demônio

Segundo passo, veio a cocaína

Morava com a minha mãe, me lembro da minha mina Felícia

Cheirava comigo sem parar

Dois loucos 24 horas no ar

Parei com estudo, perdi até o trampo

Ganhei o mundo e uma desilusão e tanto

Perdi a minha própria mãe, que trauma!

Morreu de desgosto por minha causa

Nem assim eu consegui parar, vixi!

Só a morte pode me libertar

$\mathrm{Eu}$ roubava pra sobreviver, ou melhor,

Pra manter o vício e não morrer, que dó!

Suicídio, lento era o processo

Eu nunca fui estrela, eu nunca fui sucesso

Contaminado, HIV positivo

Qual a diferença do inimigo pro perigo?

Aí, são duas da manhã e faz chuva

Pesadelo ainda continua

Continua ladrão, o pesadelo ainda continua

Um dia frio

Um bom lugar pra ler um livro

E o pensamento lá em você

Eu sem você não vivo (depoimento de um viciado)

Um dia frio

Um bom lugar pra ler um livro

E o pensamento lá em você

Eu sem você não vivo (depoimento de um viciado)

Amigo, aí, eu falei esta palavra

Me desculpa foi erro, não pega nada

Eu nunca tive amigo nessa porra

Só prejuízo na vida de ponta a ponta

Mas quem vai se importar, eu sou apenas mais um

Aidético viciado, infelizmente comum

Mais um entre mil ou um milhão, ladrão

Escravo desta triste detenção

Eu não sou Rafael e nem a Vera Fischer

A minha história, parceiro, é mais triste

Eu nunca engoli escova de cabelo

Mas já matei pelo crack e por dinheiro

Puta que pariu, o inferno me chama

Quem sabe lá eu consigo a fama ou o drama

Ou a lama de fogo eterno

Condenado à escuridão do inferno

Hoje, eu sou louco de intensa coragem

Com o ferro a favor do crack

Não sei se a malandragem é minissérie ou história

Mais sei que a carreira parceiro é sem glória

Vou tentar não matar mais ninguém

Chega de ser refém, eu preciso é do bem 


\author{
Vou entregar à Deus a minha vida \\ Vou acreditar nas palavras da Bíblia \\ Arrependido de todos os pecados \\ Ter conseguido escapar do diabo \\ Espero que a minha história sirva de exemplo \\ Pra quem tá começando, parceiro, como eu comecei \\ Que se afaste das drogas enquanto é tempo \\ Pra não provar do veneno que eu provei \\ É embaçado, sangue bom, vai por mim \\ Tudo nesta vida tem um fim \\ São duas da manhã, faz chuva \\ Eu vou orar pela minha alma e pela sua \\ É madrugada, faz chuva \\ Eu vou orar pela minha alma e pela sua \\ Um dia frio \\ Um bom lugar pra ler um livro \\ E o pensamento lá em você \\ Eu sem você não vivo (depoimento de um viciado) \\ Um dia frio \\ Um bom lugar pra ler um livro \\ E o pensamento lá em você \\ Eu sem você não vivo (depoimento de um viciado)
}

A música parece complementar a sua fala para tocar os meninos presentes no que se refere aos elementos de desgosto da mãe, do vício em drogas, da ausência de bens materiais de status, do arrependimento dos "pecados" e da noção de entrega da vida a Deus. Repetindo o script do dia anterior, Rafael fala aos adolescentes que "o crime conta mentiras e a gente ainda repete isso" e que a "lei do crime está escrita no rap". Ele diz ter sido fã de músicos de rap e depois se dado conta de que havia sido fã de "um cara que falava muita besteira", porque essas músicas "repetem as mentiras do crime, porque a verdade é que raramente o cara consegue alguma coisa [no crime]". "Pagar pelo seu crime", diz Rafael, “é o certo". No que tange às drogas, usa o mesmo exemplo do dia anterior, o de que quem usa drogas diferentes é diferente, quando na verdade, diz Rafael, tanto quem usa cocaína e é "considerado" quanto quem fuma crack e é "tirado" ficando lá "se mordendo", "todo mundo noiado". Fazê-los acreditar que o "o cara que tá lá fumando crack na rodô [rodoviária] é pior que tu que tá cheirando" e que as pessoas que consomem drogas diferentes são diferentes "é só pra começar a matar uns aos outros". Rafael conta episódio em que um amigo lhe perguntou "quem será que vai matar o outro primeiro?".

Rafael falava muito por códigos também, referiu-se a um 155 e a 157 algumas vezes, que fazem alusão aos atos infracionais análogos aos crimes de furto e de roubo, 
respectivamente, presentes no código penal brasileiro (DECRETO-LEI N ${ }^{\mathrm{O}} 2.848$, DE 7 DE DEZEMBRO DE $1940^{26}$ ). Rafael contou também da sua trajetória: gostava do "bagulho doido, da bagaceira", da adrenalina. Família falava que ele não tinha mais jeito. Um tio crente dizia que ele era o demônio. Mas ele lembra os meninos que o "cara não nasceu ruim, ficou ruim por causa das coisas que ele passou, ninguém nasceu roubando e matando". Rafael diz que o jeito de olhar e de falar muda quando o "cara entra no crime" e que "ninguém nasceu usando droga". "O difícil", diz ele, "é desaprender, é difícil sair e o cara vai sofrer muito pra conseguir". Rafael fala da mudança como algo difícil, mas possível e traz elementos em sua fala para tentar mostrar isso:

Ninguém é mágico, mas quando o bagulho fica sério, ninguém segura o cara. Mãe chama pra ir pra Igreja, o cara não quer ir, acha que tá contra ele. Se eu não quisesse o seu bem, eu te chamava pra fumar um. Você tem a chance de mudar, mas você vai ter que lutar pra mudar.

Mais uma vez ele retoma o tópico do reconhecimento, que é muito importante em sua fala para pensar as atitudes dos adolescentes: "o cara anda fumando na porta do colégio e todo mundo considera o cara". Ele faz alusão à ideia que fazia da vida "nas quebradas", pensava "se todo mundo morre assim, por que tenho que morrer diferente? Vou morrer assim também”. Mas Rafael fala aos meninos que eles não devem pensar dessa maneira, pois se "outros morreram assim, o problema é deles". Ele elencou os principais motivos para os jovens não saírem do crime: ou é viciado em drogas, ou não percebeu que o crime não compensa ou "tá devendo". Muito habilidoso com as palavras, bom orador e, sobretudo, sabendo falar a língua dos jovens, em especial por ter uma trajetória dentro do sistema socioeducativo, como os meninos, ele usa o termo "malandragem" valorado diferentemente. Ele diz: "se tu é malandro, usa a sua malandragem e sai do crime". Ele diz aos jovens que eles ainda não perceberam a força que eles têm. Menciona que no fim de sua trajetória infracional, começou a fumar crack e percebeu que toda a glória de roupa cara "vira fumaça", que toda "glória de mulher vira fumaça", que ele tinha que ficar longe dos "moleque doido porque senão tudo virava fumaça". Resgata a estigmatização: "porque a gente é sempre ex alguma coisa". Ontem ele fora um socioeducando, hoje ele é um ex-socioeducando. Essa dimensão é abordada também por Côrtes, ao afirmar que os pregadores, que eram "bandidos", em realidade, sempre ocupam uma posição liminar, uma vez que a sua condição anterior

\footnotetext{
${ }^{26}$ http://www.planalto.gov.br/ccivil_03/decreto-lei/Del2848compilado.htm, acesso em $1^{0}$ de julho de
} 2015. 
parece não os deixar completamente e é, inclusive, diversas vezes mencionada pelos novos pregadores. Rafael fala ainda dos "caras mente fraca", "o cara que falava que a culpa era da sociedade, mas a oportunidade que tu tinha tu jogou fora, agora tu vai ter que criar a sua oportunidade".

A família, por sua vez, é outro elemento que, aliado à sua conversão religiosa, foi capaz de operar mudanças em sua vida. Ele conta mais sobre a sua vida, dizendo que a sua esposa foi "um milagre em sua vida" e que "o pai dela é cana". "O malandro', disse Rafael, "vai só enrolando, vai mentindo" e no final "você não tem nada, você tem só prejuízo e uma mãe lá que vai te visitar". Como no dia anterior ele retoma a história sobre ter querido ser engenheiro civil, mas que não deu e que este "não era o plano de Deus" para ele.

Weber (2004) lembra que, em Lutero, o conceito de vocação profissional permaneceu muito tradicionalista, sendo considerado aquilo que o ser humano tem que aceitar como "desígnio divino", ao qual tem que se "dobrar". O desenvolvimento do luteranismo ortodoxo sublinha essa crença que identifica a incondicional obediência a Deus à aceitação incondicional da situação dada. Na perspectiva tradicionalista, há a ideia de "destinação", em que se entende que o indivíduo deve permanecer na profissão e estamento em que Deus o colocou e manter sua ambição terrena dentro dos limites dessa posição na vida que lhe foi dada.

Rafael disse que à medida que foi mudando, foi reconquistando a confiança dos familiares em casa e das outras pessoas: "a tortura pode marcar seu corpo, mas a confiança que você dá pro cara que não merece confiança, isso vai marcar a alma do cara". Sobre "curar a alma", ele conta novamente a história de perdão do Senhor do Mercado, cuja família ele havia prejudicado, mas Rafael lembra que, apesar desse fato, é importante lembrar que "Deus perdoa, o ser humano não".

$\mathrm{O}$ ato de pedir desculpas e ser perdoado, como no que foi exposto acima sobre a experiência de Rafael com o dono do mercado contra o qual havia cometido tentativa de latrocínio, coincide com a lógica de expiação de pecados própria de uma ética cristã e mais alinhada ao protestantismo tradicional, corrente em que se encontra Rafael. No esquema neopentecostal, como nos falou Côrtes, isso não se dá dessa forma, pois o que é individualizado não é a culpa, mas sim a presença do demônio que estaria guiando a ação de uma pessoa.

Rafael diz que o "remédio da tua família [virando-se para os jovens] é a saída do crime". "As pessoas", continua ele, "não têm mais valor hoje não, esqueceram o que 
tem valor". Rafael fala aos adolescentes que o caso deles como pode ser como o seu e os questiona acerca de seus sonhos: vários mencionam que queriam ser advogados, outro diz que gostaria de ser jogador de futebol, outros dizem ainda: empresário, professor de educação física, “da aeronáutica” e enfermeira. Então, ele os indaga:

você acha que vai conseguir realizar esse sonho no mundo do crime e das drogas? O crime só traz desgraça e tristeza, aqui começa o seu sonho, aqui na UAMA. As pessoas aqui querem fazer o bem pra você, te arrumar documento, trampo, estágio. Se tu não consegue nem aqui, quando tu for pro CAJE vai ficar louco.

Rafael toca outra música, um "rap gospel”, que fala da "palavra de Deus", tratase da música "Vida Eterna", da banda "Liberdade Condicional"27. "Esse som", fala Rafael, "dá uma linha pra seguir". Ele diz: "se você não tem força pra vencer, esse é o caminho, o poder da fé".

Por quanto tempo ainda vamos ter que suportar

A crueldade a humanidade em decadência

Ricos cada vez mais ricos

Pobres cada vez mais pobres

Quem será que vai levar o maior tombo

Vejo a parte bem sucedida materialmente

Puxa do bolso algumas migalhas e novamente

Achar que estou colaborando com um mendigo que pede esmola

As granfinas enfiam a mão no fundo da sacola

Joga uma moeda viram as costas e vão embora

Que ajuda é essa? Queira me explicar

Onde o cara nunca se levanta, continua no mesmo lugar

E ao escurecer, como é que vai ficar?

Ele procura um lugar pra se deitar

Mas a noite é longa e demora

O frio é intenso e ele chora,

Abandonado pelo mundo seu destino é esse, ser maltratado e humilhado véi vai ser assim

Mais uma vez a palavra de Deus é confirmada, onde Ele é o princípio, o meio e o fim da estrada

Todos te abandonaram mas Deus não, felizes são os que sofrem a perseguição Por isso mano não fique desesperado, lembre-se de Jesus e ficarás aliviado

Pois Ele é a fonte da vida e Nele está a resposta,

Tenha fé em Deus e aguarde Sua volta

pode demoraarr

Mas tenha certeza que Ele vai voltar

Pois Ele é a fonte da vida e Nele está a resposta, Tenha fé em Deus e aguarde Sua volta pode demoraarr

\footnotetext{
${ }^{27}$ Fonte: http://letras.mus.br/liberdade-condicional/183270/, acesso em 13 de maio de 2015.
} 
Mas tenha certeza que Ele vai voltar

Precisamos de Jesus meu irmão

Só Ele te salva é da vida eternaa aahh aahh (Precisamos de Jesus meu irmão)

Precisamos de Jesus meu irmão

Só Ele te salva é da vida eternaa aahh aahh (Precisamos de Jesus meu irmão)

Enquanto muitos trabalham para se segurar

Seus filhos que nasceram é preciso sustentar

Outros ficam vagando pela rua o dia inteiro

A idade vai chegando e vem a falta de dinheiro

Pra comprar um pisante, um bermudão uma peita

Tomar um refrigerante, fim de semana ir na feira

Seus pais com muita dificuldade ganham pouco

pagar as contas fim de mês, maió sufoco

Abandonou a escola cedo $\mathrm{d}+$, foi ignorante não quis ouvir seus pais

Se enturmou com a mulequada da quebrada

Sumia no mundo passava dias sem voltar pra casa

E sua mãe coitada, desesperada

Com 15 anos cometeu seu primeiro delito

Deu azar foi preso e ficha no distrito

A partir daquele dia era perseguido

Altos bo's altos assaltos, se formou bandido

Andar armado e drogado era sua sina

Virou patrão da merla e da cocaína

Se achava o tal, carro zero

Com 18 anos de idade, era respeitado na cidade, até que um dia a casa caiu

Dormiu no ponto

E agora, e agora

$\mathrm{Na}$ rua era temido na cadeia ele chora

Não adianta aloprar nem quere tirá onda, só quem foi lá sabe como é que é

Nos dias de rosa, comprou uma faca, ficou garantido, faz parte da roda

Bateu de frente no pavilhão com um inimigo seu

Que há anos paga por um crime que não cometeu

"Na hora no banho de sol vamô acertar aquela parada, por sua culpa estou preso sem dever nada"

Mas bem na hora do confronto um detento gritou: "Cadê o amor de Deus nos seus corações, já não basta o lugar que vivemos, pra que mais confusões, perdoe ele mano, perdoe ele irmão!"

Precisamos de Jesus meu irmão

Só Ele te salva é da vida eternaa aahh aahh (Precisamos de Jesus meu irmão)

Precisamos de Jesus meu irmão

Só Ele te salva é da vida eternaa aahh aahh (Precisamos de Jesus meu irmão)

Tenho certeza que Jesus é o nosso salvador, morreu por nós demonstrou seu grande amor, lavou nossos pecados morreu com grande dor, e só Ele merece o nosso resplendor

Se hoje passo fome pelas ruas meu irmão

Posso morrer mas quero ter Jesus no coração

Acostumado a viver de migalhas nesse mundo, ser chamado por muitos de vagabundo 
Esqueceram um dos mandamentos que aqui Você deixou, e assim foi esclarecido: "Amar a Deus sobre todas as coisas e ao teu próximo como a ti mesmo"

Precisamos de Jesus meu irmão

Só Ele te salva é da vida eternaa aahh aahh (Precisamos de Jesus meu irmão)

Precisamos de Jesus meu irmão

Só Ele te salva é da vida eternaa aahh aahh (Precisamos de Jesus meu irmão)

E Ele vai voltar

E Ele vai voltar

Jesus meu irmão!

A letra acima se remete à necessidade de Jesus e Deus na vida das pessoas e como Ele seria capaz de oferecer a salvação. A força de Deus aparece no discurso de Rafael, sobretudo na sua trajetória de abandono da dependência química. Ele saiu do crack sem precisar de uma clínica de reabilitação, como explicar isso? "Só Jesus mesmo". Ele termina a palestra do segundo dia falando para os meninos seguirem "o caminho do bem, o caminho do mal é o mais fraco, pense duas vezes antes de voltar para aquele seu cotidiano". A disciplina que Rafael teve para conseguir abandonar o vício nas drogas é, de certo, admirável e conectada com sua experiência de conversão.

Nesse momento, a supervisora Letícia pede aos adolescentes que partilhem as informações com os seus responsáveis e um jovem, bem magro, pergunta a Rafael como parar o crack, ao que ele responde:

a cadeia até dá ajuda pro cara, eu ficava longe de quem fumava, fumava só maconha e quando fumava, fumava em casa sozinho, não bebia, não saía pra festa e fui pra Igreja, lá foi meu centro de reabilitação, eu tinha que ter meu esforço e Deus ia me ajudar também. E não ir nas quebradas onde tinha guerra.

Rafael identifica o poder de Deus como algo inexplicável e forte o suficiente para alterar rumo de sua vida, desde que associado, claro, à uma "luta individual" pela mudança e ao trabalho duro, no sentido de uma ética profissional, conforme Weber. Rafael traça um claro corte entre uma moral positiva e uma moral negativa, inserindo-se na lógica protestante tradicional que entende o trabalho como algo positivo, fazendo-nos refletir sobre a máxima da "salvação" e busca da certeza desta por meio da vocação profissional e não ociosidade; e ainda, aludindo à negatividade do reconhecimento por meio da ostentação de bens materiais supérfluos ou de luxo, que o protestantismo ascético critica, bem como aos meios ilícitos usados pelos meninos para alcançarem tais bens. Rafael se insere num panorama de conduta racionalizada da vida, por oposição a 
soluções mágicas, tal como identificou Côrtes como sendo mais comum às lógicas protestantes pentecostais e neopentecostais.

\section{2 - RAFAEL: “QUEBRANDO AS ESTATÍSTICAS”.}

Após a atividade do primeiro dia, peço para conversar com Rafael, para saber um pouco mais de sua trajetória e lhe fazer algumas perguntas. Adventista do sétimo dia, Rafael visita todas as unidades de MSE do DF quando está no Brasil e diz ter criado um projeto chamado "quebrando as estatísticas", em alusão ao fato de que "de 10 mil que está no sistema, só um sai” e de que faltam políticas públicas e sociais para os egressos. O funcionamento do sistema, para ele, depende da mudança de pensamento de quem trabalha, do governo. Para ele, a assistência religiosa no socioeducativo faz toda a diferença, afinal, como "pode ser mesmo perdoado aquele menino"? A política do sistema socioeducativo, diz, "tá errada, ao contrário", porque se tem as medidas mais leves no começo e ele crê que deveria ser o oposto: os meninos que cometem atos infracionais deveriam entrar no sistema socioeducativo primeiro pela internação. Ele se explica:

Porque quando você para o jovem, você pode trabalhar com a cabeça do jovem. Parou o ato, aí você pode ressocializar ele. Como está hoje, quando o jovem vai pra internação, ele já tem mestrado no crime e fica difícil reverter o processo. Mas a internação tem que ter prazos certos e tem que ter políticas públicas e sociais para os egressos. A pessoa tem que ter muita força de vontade, não estudou, ela só sabe roubar, não sabe fazer nada. Quem vai dar vaga? Hoje, de 100 meninos atendidos, só 5 conseguem vagas de estágio, isso é ridículo!

Rafael entende que o caminho que um adolescente deveria percorrer no sistema socioeducativo seria da Internação, para a Semiliberdade para chegar, no final, às medidas em meio aberto. O jovem deveria entrar no sistema pela internação para ele "sair maduro para conseguir escolher e não como medida punitiva, no máximo seis meses ou um ano, a depender do caso". Interpreto a visão de Rafael como uma perspectiva mais próxima de um modelo tutelar, que concebe o jovem numa etapa inicial como incapaz de realizar boas escolhas, tendo que ficar, por isso, controlado, inclusive em termos de uma disciplina do corpo, haja vista a restrição completa de liberdade a que ficam sujeitos os adolescentes no contexto da internação. O universo simbólico no qual Rafael se insere, aliás, condiz com sua ética religiosa, que seria parte 
de uma primeira etapa da modernidade ocidental, que Côrtes lembra ser uma etapa mais disciplinar e em que as próprias igrejas protestantes teriam uma ética moral religiosa mais rigorosa e bem definida em relação às vertentes pentecostais, mais recentes. Da perspectiva de Rafael, o adolescente só poderia mesmo ser ressocializado, devolvido à sua comunidade, uma vez que estivesse pronto para isso, apto a fazer suas próprias escolhas.

Sobre a sua mudança de comportamento, ele disse que Deus abriu seus olhos, ele recorreu a Deus, que foi a "força pra vencer". Ainda sobre seu processo, ele diz que "Não foi o sistema, foram as pessoas que estavam ali" que o fizeram mudar. E também a Igreja, claro, que, entre outras coisas, o tornou menos agressivo.

Sobre seu momento de crise, da qual decorreu sua conversão, ele lembra: "na hora da morte, foi Deus". Ele também fez uma reflexão sobre sua vida nesse momento: "Eu já tenho tanta guerra”, pensou, "percebi que nunca ia terminar”, concluiu. Mas ele gostava da adrenalina do crime: "sempre fui 'pivetinho', sabe? Nunca parava quieto". Mas então Rafael achou prazer em outras coisas. Disse-me que vai pular de paraquedas, que ele sempre quis, e que essa sua vontade tem a ver com o fato de ele sempre ter gostado de adrenalina.

Rafael contou ainda que os meninos que estão no crime almejam tudo que as pessoas comuns almejam: reconhecimento, dinheiro.

No crime, parece que vai dar certo, mas não dá. Mas eles não tavam pensando errado quando entraram no crime [no sentido de querer coisas que todos querem, entendi], mas tomaram e medida errada para conseguir.

Sobre o evento e a mudança na sua vida, ele ressalta que quando "o cara está à beira da morte, o cara começa a pensar”. Ele disse que esse momento, como já mencionado, foi um marco em sua vida e foi como se ele tivesse voltado ao seu pensamento "primitivo", a pessoa que ele é.

A religião, diz, dá força de vontade, força em Deus, mas ele entende que "tem que fazer a sua parte". Segundo Rafael, existem coisas milagrosas que "não posso te explicar”, o perdão das pessoas é uma delas. Perguntei sobre a reação do público: viu que alguns já tinham "maturidade no crime", que ele explica que é quando o cara já vê que o crime não compensa.

"Eu enxergo a mudança neles", diz Rafael, "eu era explosivo". Em vários momentos, Rafael se pergunta:

Será que eu era aquele que fazia as coisas erradas? Sou ruim? Será que sou bom ou ruim? Não nasci nem roubando nem matando. Sempre gostei de adrenalina e 
o crime ofereceu isso. Será que sou aquele ou esse? Acho que não sou esse, mas nasci para ser esse (o bom). Sempre fui problemático e nasci para ser essa pessoa que sou hoje e posso ser ainda melhor.

Para ser melhor, há de se achar a conduta correta em Deus. Segundo me conta, muitos continuam no crime porque gostaram mesmo sabendo que não recompensa. Há pessoas que também continuam porque gostam do reconhecimento, gostam de ser chamado de "traficante doido", "moleque ruim", é a questão da "glória do crime". Perguntei sobre a diferença entre falar para os adolescentes da UAMA e para aqueles da internação. Ele disse que é muito diferente. Tirar o sorriso de alguém e desvencilhar aquela atmosfera do crime é bem mais difícil na internação. É um local mais triste. Quando ele fala na internação, às vezes um adolescente solta "o que que eu tô fazendo nessa porra?" ou então "eu fiz tudo errado!". É nesse momento, ele disse, que pensa que conseguiu "tocar o coração" dos jovens e que a sua ação pode vir a ter uma consequência positiva.

Após a atividade, concentrei meus esforços também em observar as conversas entre as profissionais sobre o evento. A psicóloga Clarice tentou dar reforços positivos a Rafael afirmando "sua faculdade tá te fazendo bem hein, tá cada vez melhor" em alusão à melhora da sua oratória.

Sobre a força da família para que ele fosse uma exceção à estatística, ele diz:

se eu não tivesse casado, com as minhas filhas, se tivesse solto por aí, vixi....Não sou que estou ajudando por ser pastor, é a na verdade a Igreja que tá me ajudando, o fato de eu falar para os outros, de eu ser exemplo também me faz continuar nesse caminho do bem.

Não posso deixar de mencionar uma dimensão mais crítica da fala de Rafael ao aludir à questão da "estatística" para pensar a mudança, algo também presente na letra da segunda música que tocou aos adolescentes no segundo dia de oficina, a saber, o contexto social em que os adolescentes se inserem. Quando estávamos na sala maior, após o primeiro dia de oficina, Rafael afirmou:

A gente fala lá que tá fazendo faculdade na Argentina e parece que tá tudo lindo, mas na verdade por trás tem muito esforço, muito sofrimento. Eu falei umas verdades pro doutor lá, que o sistema tá errado, tá invertido. E pra Dra. Paula também, com todo o respeito, mas o que aquela mulher tá fazendo lá? Vai dizer que o sistema que recupera os adolescentes? É um em um milhão que consegue sair! Aí ela vai e me fala do caso do Marcos, que estudou na internação e passou na UnB... É diferente, ela não vê que ele já tinha uma estrutura, se tu conversa com ele, tu vê que ele é um crânio, ele sempre estudou, os pais dele sempre estudaram, quando ele foi pra internação ele ia fazer o quê? Estudar né...Aí vai dizer que foi o sistema que fez isso por ele? 
Assim, Rafael parece questionar a própria ação do sistema socioeducativo, haja vista que a estrutural social no qual ele se insere padece ainda de muitas dificuldades e desigualdades. Marcos, que virou, inclusive na mídia, o grande ícone de força de vontade e possibilidade de mudança, é, entretanto, uma exceção à regra, não só no sentido de ter conseguido sair de uma trajetória de cometimento de atos infracionais, mas também porque a estrutura que ele tinha de vida diferia do que tem a maioria dos adolescentes do sistema socioeducativo, de forma que não se pode atribuir o seu êxito à politica do sistema socioeducativo. Em última instância, o posicionamento de Rafael parece também tirar um pouco do indivíduo a responsabilidade por sua própria mudança, haja vista que existem outros elementos condicionantes que não só força de vontade e lutas individuais.

Ele tem a ideia de que a internação como está também não vai resolver nada, porque "quando tinha atividade coletiva lá [quando eles estava internado], eu nem ia, eu preferia ficar no quarto". Supervisora Letícia diz "é, pra preferir ficar no quarto é porque tinha alguma coisa errada, né?". E Rafael prossegue: "mas não quero desmotivar vocês não, continuem trabalhando á'”. Algumas profissionais riem e dizem: "iiih, a gente já sabe como as coisas funcionam”. Rafael sublinha: "de 10 mil, um sai. Eu e o Marcos somos exceção".

Em um momento informal da conversa, após a palestra, já na sala das profissionais, o jovem começa a nos contar dos ganhos materiais que obterá quando finalizar o seu curso de teologia e virar pastor da Igreja Adventista do $7^{\circ}$ Dia e, em determinado momento, ele diz: "mas também tudo isso é para eu só me dedicar à vida de pastor, não posso abrir uma padariazinha ou fazer um concurso, eu vou viver para isso e se eu sair também já era, não faço nada com esse meu diploma de teologia". Nesse momento, a mesma psicóloga Clarice afirma: "nada não, o diploma também serve para o seu crescimento pessoal e se um dia você quiser poder dar aulas também...”. E o ex-socioeducando retruca: “não, não quero saber de dar aulas, eu quero mesmo é ser pastor. Já fui convidado para trabalhar na Secretaria, e eu não quis, não é nem uma questão de salário, mas eu acho que posso ajudar muito mais gente com meu trabalho como pastor". O palestrante nos contou orgulhoso que a sua Igreja é uma das poucas que exige o curso de teologia para os pastores e em vários momentos afirmou ser a sua religião uma coisa séria e racional e que não tem "magia".

Mostrou-nos os livros que vende e nos contou como era difícil atingir as metas de venda para custear a faculdade. Nesse momento, Rafael faz uma piada dizendo "eu 
podia tá roubando, eu podia tá matando, mas tô aqui vendendo livro". Todos riem. Quase todas as profissionais compraram um exemplar dos livros, que se dividiam em três coletâneas, além de uma bíblia para crianças: uma de saúde, uma de família e uma "religiosa". Eram livros que falavam sobre o relacionamento conjugal, o sucesso econômico na vida, livros motivacionais e outros que falavam sobre alimentação saudável. Um deles, que ele tentou me vender, ele dizia ser um livro especial, chamavase "O amanhã começa hoje". Recusei a compra e ele pareceu decepcionado não deixando de me perguntar, ao despedir-se de mim, se no dia seguinte eu iria novamente à Unidade ouvir a sua palestra e comprar um livro. Eu afirmei que sim para as duas perguntas. No outro dia, após a segunda palestra de Rafael, fiz a compra do livro, optando, entretanto, por outro título que não o que me fora recomendado por Rafael, o livro intitulado "O poder medicinal dos alimentos". 


\section{CAPÍTULO 4 - SOBRE "MUDANÇA DE VIDA": ENTENDIMENTOS E EXPECTATIVAS ACERCA DA GESTÃO DAS TRAJETÓRIAS DE VIDA DOS ADOLESCENTES EM MEDIDAS SOCIOEDUCATIVAS}

No presente capítulo, buscarei fazer um breve resgate de valores ocidentais modernos que parecem pautar a legislação do ECA e a atuação das técnicas da Unidade de Atendimento em Meio Aberto onde a pesquisa foi desenvolvida. Mostrarei, entretanto, que os discursos das técnicas sobre a política do sistema socioeducativo nem sempre convergem e que há uma diferença de expectativas entre as profissionais e, principalmente, entre essas e os responsáveis legais dos jovens que cumprem medidas socioeducativas na UAMA. Esses contrastes, tal como entendo, deixam entrever "métodos e técnicas" diferentes para se lidar com jovens autores de atos infracionais. Como já mencionado na introdução deste trabalho, há, de um lado, noções que remetem a soluções mais disciplinadoras e repressivas e outras que, por outro lado, fazem menção a uma vontade emancipatória e liberal do sujeito que se encontra em construção e "em fase de desenvolvimento", isto é, do adolescente atendido. Como pano de fundo dessas distintas visões sobre como gerir os adolescentes e fomentar a alteração de sua trajetória de vida, o que é entendido pelas profissionais como o principal objetivo da política em questão, trarei à baila alguma discussão sobre técnicas de governo.

Ao falar das preocupações no que tange à gestão da vida desses adolescentes por parte dos profissionais envolvidos com a sua "transformação" e de seus responsáveis legais, procurarei também problematizar brevemente algumas categorias acionadas por eles como fundamentais para que os jovens parem de cometer atos infracionais e "mudem de vida".

Inicio o capítulo abordando algumas situações etnográficas com as quais tive contato no tempo em que estive na UAMA. O que descreverei a seguir servirá como mote para que sejam discutidos tanto valores de uma modernidade ocidental quanto técnicas de governo que permeiam esse contexto e que também surgiram em campo.

A primeira situação etnográfica que gostaria de trazer para discussão é uma das que primeiro me fez refletir acerca das diferentes perspectivas - orientadas, por vezes, pelas diferentes trajetórias das profissionais - que se encontram na UAMA no que se refere ao tipo e à forma da mudança almejada para a trajetória de vida dos adolescentes atendidos. Nessa primeira situação descrita, trago a visão da supervisora Letícia, a 
primeira supervisora da UAMA que entrevistei ${ }^{28}$, e a confronto com a perspectiva de Clarice, uma psicóloga recém-chegada na unidade.

A supervisora Letícia se frustra bastante ao entender que "não conseguiu ajudar" os adolescentes atendidos e diz se sentir mal por isso, especialmente por ter sido ela própria, ao longo de sua vida, atendida por políticas sociais, que se mostraram eficazes para ela. Contrasto a sua visão com a de Clarice que, por sua vez, afirmou diversas vezes que "a gente [em referências às profissionais da UAMA] não muda ninguém, quem muda são eles próprios, a gente só orienta, abre a cabeça deles pra outras possibilidades, faz eles refletirem e verem os caminhos possíveis, mas a escolha é deles, não é nossa, não é do pai deles, é deles, daí a importância da responsabilização também".

Para introduzir a discussão, relato um pouco do que as profissionais me contaram sobre suas perspectivas sobre o trabalho na UAMA.

Como mencionado antes, Letícia ocupou o cargo de supervisora da UAMA até final de janeiro, quando foi substituída pela supervisora Regina. Letícia tinha uma trajetória um pouco diferente da trajetória dos demais profissionais da Unidade, como ela fez questão de pontuar. Como mencionado no capítulo 2, diferentemente do restante dos profissionais, ela viera de uma realidade socioeconômica mais humilde, com família "desestruturada", como a dos meninos atendidos na UAMA, e do que ela chamou de uma "trajetória de vida beneficiada pelas políticas sociais". Assim, como numa espécie de lógica da dádiva (MAUSS, 2008), ela sente que deve retribuir à sociedade e essa é uma das razões pelas quais ela decidiu trabalhar na área de assistência social. Letícia sempre gostou da assistência social e foi assistida por ela e que enquanto parte do sistema socioeducativo, ela deve trabalhar onde for necessário e se preocupa em continuar contribuindo para os jovens em medida e anseia contribuir de forma maior para a sociedade. Assim, a profissional se frustra muito ao saber que algum menino atendido reincidiu, por exemplo.

Para Letícia, os jovens "infracionam” por conta de sua condição de vida de "ser humano", em que "falta acompanhamento familiar" e "estrutura psíquica para fazer a 'boa opção"”. Ela entende, portanto, o meio desses jovens como um complicador para que alterem a sua trajetória de vida e percebe a sua limitação enquanto profissional da

\footnotetext{
${ }^{28}$ Como mencionado anteriormente, devido à mudança de gestão ocorrida, no período da minha pesquisa, duas pessoas ocuparam o cargo de supervisora da UAMA. Em janeiro, ele era ocupado por Letícia e, a partir de março, por Regina.
} 
Unidade ligada mais a questões materiais ou ao que chamou de "incompletude institucional", referindo-se às diversas carências que os jovens atendidos têm e que a "Rede" não dá conta de suprir. Os exemplos frequentemente citados, não só por ela, mas outros profissionais, dizem respeito às necessidades de atenção de saúde, para lidar com quadros de drogadição e outras doenças.

Clarice, por sua vez, é psicóloga e também faz parte da carreira do sistema socioeducativo do DF, embora de entrada mais recente no quadro. A frustração da carreira, para ela, é o profissional se dar conta que, em realidade, não está na sua governabilidade evitar o cometimento de atos infracionais pelos adolescentes, haja vista que a decisão por cometê-los é só deles. Ainda assim, ela se sente motivada pelo trabalho por acreditar que pode fazer algo pelos jovens na medida em que suscita neles uma reflexão. Mais uma vez, ela me diz que "as pessoas querem que os profissionais 'mudem o jovem', mas essa escolha é dele”, assim, "os profissionais não podem se responsabilizar pelas escolhas dos outros [dos jovens], mas podem ajudá-los a 'pensar sobre o percurso de suas vidas"" e de que eles "são mais do que ato que cometeram".

Clarice procura também fazer um trabalho de "responsabilização", atribuindo aos jovens a responsabilidade pelo estigma que eles têm, tanto na família como na escola, por exemplo. Ela procura orientar os jovens durante os atendimentos e mostrar que na UAMA eles podem descontruir essa imagem que cunharam para si. Para ela, a lei - o ECA - é boa, porque é embasada, segundo ela, muito "utópica", mas na prática “não ocorre assim, se ocorresse, os jovens não estariam assim [como estão hoje]". Para ela, o maior êxito de seu trabalho é "perceber que o jovem tem plena consciência do que ele fez e de como isso afeta ele e as pessoas próximas e a partir dessa ampliação de consciência, fazer suas próprias escolhas". Nessa frase de Clarice reside a ideia de uma "responsabilização", que discutirei mais adiante.

Fora os momentos de conversa mais "estruturados", vivenciei momentos em que havia interações mais espontâneas das profissionais comigo e entre elas. Assim, apesar de já ter começado a perceber que havia um choque de perspectivas entre as profissionais, conforme fica visível no que foi reproduzido acima, estive presente em outra situação em que ambas interagiam e que reforçou a minha suposição deste contraste.

Conforme descrito anteriormente, após a primeira apresentação do exsocioeducando Rafael, Letícia comunica sua frustração em ir trabalhar na internação, por sentir que naquele ambiente ela pouco poderia fazer pelos adolescentes, haja vista 
que, internados, nada iria acontecer de mudança em suas vidas ao que a psicóloga Clarice imediatamente retruca dizendo “é, vão ficar lá por escolha deles!". Esse episódio possibilitou captar uma nítida distinção da forma como operavam as duas profissionais no que tange à situação vivida pelos adolescentes.

A partir desse contraste, pude perceber que a supervisora Letícia, ao mesmo tempo em que reconhece a existência de um contexto estrutural de "vulnerabilidades", enxerga maiores possibilidades de intervenção na vida dos adolescentes atendidos por meio de seu trabalho na Unidade e parece não compreender muito bem as causas de sua limitação, uma vez que advinda de um contexto próximo ao deles. Por outro lado, Clarice põe um peso maior no nível individual, especialmente se olharmos para a sua afirmação de que a escolha sobre a vida dos adolescentes é deles e de mais ninguém, portanto, bem compatível com uma ideologia moderna ocidental que tem o indivíduo como um sujeito com lugar privilegiado, seja ele referente a uma titularidade de direitos ou à própria penalização. A própria formação acadêmica de Clarice - a psicologia pode ajudar a compreender a ênfase desta profissional em um nível mais individual das condutas dos jovens.

A respeito da noção de indivíduo, cara às legislações brasileiras e internacionais atuais, devemos retomar Louis Dumont, em sua obra "Essais sur l'individualisme" (1983). Neste trabalho, ele opõe a sociedade de castas e hierárquica indiana, holista, à sociedade ocidental moderna, individualista. Dumont aborda a dimensão ideológica da modernidade, afirmando que, nela, o "indivíduo" não é apenas o sujeito empírico, mas um valor e que há toda uma configuração de valores que gira entorno da ideia de indivíduo. Por outro lado, ele entende que em contextos hierárquicos e não igualitários, o que marca a hierarquia não é tanto a assimetria e a desigualdade, mas a ideia de complementaridade, ao contrário do que pensava a sociedade ocidental sobre a Índia. Assim, a localização do valor central da sociedade indiana não está na parte, mas no todo, e as partes não são equivalentes, mas complementares. Quando a hierarquia é tomada como valor, diz o autor, as partes não são equivalentes, como ocorre nas sociedades ocidentais modernas ditas igualitárias, mas complementares.

Numa sociedade marcada por uma ideologia holista, em que o valor maior não é o individuo, mas o todo, em que as partes têm que trabalhar de forma complementar, para que o todo funcione adequadamente, não pode existir o indivíduo como ser moral, ele só existe, então, fora do mundo, em sua relação com Deus, porque na ideologia holista ele não é possível. Toda sociedade tem elementos individualistas e holistas, mas 
o importante seria identificar onde esses valores estão na sociedade. Não são tipos de sociedade, mas que ideologias estão atuantes e em que níveis da sociedade.

Em seu estudo acerca das origens do individualismo moderno, Dumont afirma ainda que já havia um traço de individualismo nos primeiros cristãos e numa sociedade holista tradicional que concebia o indivíduo como estando "fora do mundo", e que foram necessários dezessete séculos de história cristã para que o individualismo, na forma do indivíduo-no-mundo, viesse a existir. Quando se refere ao indivíduo, o autor fala que é possível compreendê-lo como o objeto fora de nós, o sujeito empírico, o exemplar individual da espécie humana ou como um valor, isto é, como "ser moral independente, autônomo, e por consequência essencialmente não social, que veicula os nossos valores supremos e ocupa o primeiro lugar na nossa ideologia moderna do homem e da sociedade" (p. 35). O tipo moderno de cultura, no qual a antropologia se enraíza, e o tipo não moderno diferem de maneira marcante no que concerne à relação entre ideias e valores. "Nós modernos" tendemos a decompor a relação original separando os valores das ideias e em geral dos fatos, o que significa que nós separamos ideias e fatos dos todos nos quais, em realidade, eles se encontram. $\mathrm{O}$ valor é qualquer coisa que, diferente da verdade científica, que é universal, varia muito de acordo com o meio social e mesmo no interior de uma mesma sociedade. Mas o indivíduo é, como dito acima, tanto um fato observável quanto um valor para a sociedade moderna, isto é, ele é uma ideia-valor central na modernidade. A sociedade moderna, portanto, seria individualista. Por oposição a esse tipo de sociedade cujo foco está no indivíduo, estão as sociedades de tipo holista. Vê-se, a partir da análise de Dumont, que o indivíduo que antes era apenas concebido como fora do mundo vai se transformar no moderno indivíduo-no-mundo, à medida que o holismo desaparece da representação, florescendo, na consciência moderna, a atribuição do valor, de maneira predominante, ao indivíduo.

Tendo em mente ainda a diferenciação entre princípios hierárquicos/holistas e igualitaristas/individualistas, vale resgatar o conceito de "hipossuficiência", que anunciei na introdução deste trabalho. Analisando a legislação do mercado de consumo no Brasil e alguns casos de conflitos no mercado de consumo de bens e serviços no Brasil, Amorim (2008), fala da noção de "hipossuficiência" aplicada a grande parte das decisões judiciais no que se refere a conflitos entre vendedores e consumidores. Ela argumenta que esse conceito guia as decisões mais do que propriamente os termos contratuais estabelecidos entre as partes. Isso se daria por uma concepção do Estado brasileiro que entende o consumidor sempre como "o lado mais fraco" da equação. Essa 
situação parece ainda mais verdadeira em caso de consumidores pobres. A categoria de hipossuficiência, argumenta a autora, torna o consumidor uma pessoa menor, transformando a sua condição de cidadão e de sujeito nas relações de compra e venda em objeto dessas relações.

O uso do argumento jurídico da hipossuficiência dos consumidores frente a grandes corporações seria uma atitude do Estado que, ao invés de proteger o consumidor, o "amesquinharia como cidadão", afirma Amorim. Assim, a autora atenta também para o fato de não haver nem igualdade social e nem igualdade jurídica no Brasil e de que, a inexistência desta última no país, apesar de justificada por uma ideologia de "desigualar juridicamente para igualar socialmente", traria à prática, alguns paradoxos. Nessa lógica, a intervenção do Estado se justifica em benefício dos mais fracos. Deste modo, atribuindo uma "hipossuficiência" ao consumidor, o Estado se coloca numa posição de "protetor dos mais fracos", o que pode, assim, ser entendido dentro de uma dinâmica mais hierárquica do que propriamente igualitária, pensando em termos Dumontianos, e, ainda, de um ponto de vista que tende mais à tutela do que à emancipação dos sujeitos.

Como nos alertou Vianna (2002), dada a construção de uma categoria especial de sujeitos de direitos, que são os adolescentes e crianças, parece mais tentador que se caia em uma vontade tutelar que perpassa ainda muitos discursos atuais sobre formas de administração da infância e da juventude no Brasil. A ação da administração estatal sobre a infância pode ser considerada, como argumentou Vianna, um foco privilegiado para pensar a dimensão tutelar do Estado, uma vez que é exercida sobre personagens sociais que mais facilmente podem ser vistos como "naturalmente" tutelados ou tuteláveis. Parecem mais consonantes com essa lógica mais intervencionista e hierárquica, dita acima, as concepções da supervisora Letícia, bem como as de alguns pais de jovens em medidas e o de Rafael, o ex-socioeducando "convertido", que também esboçou ideias mais tutelares sobre como ele entende que deveria ser feita a gestão dos adolescentes.

Gostaria de trazer ainda uma situação etnográfica para pensar a centralidade do indivíduo e a tensão entre "escolhas pessoais", por um lado, e "contextos sociais", por outro. Pretendo também mencionar, a partir disso, estratégias das profissionais para lidarem com essa tensão, em especial como me foi dito por Regina, a segunda supervisora da UAMA que tive a oportunidade de conhecer. 
Regina é formada em psicologia e parece mais alinhada a uma percepção "menos intervencionista", se me é permitido colocá-la nesses termos, de atuação profissional, mais próxima, portanto, da visão da psicóloga Clarice. Regina falou-me do trabalho com os adolescentes em termos de fomento de uma "reflexão" junto aos adolescentes sobre suas vidas.

Tal como Regina disse compreender a concepção da política do sistema socioeducativo para os adolescentes, remete-nos também à noção central de "escolha". Ela disse "acreditar mesmo" nas medidas em meio aberto e queria trabalhar com elas por entender que são medidas mais "profiláticas" em que "a liberdade ainda está preservada" e, portanto, haveria uma "capacidade maior de intervenção no meio aberto". Orienta a sua atuação a ideia de implementar uma "proposta de intervenção que possa gerar transformação do adolescente, de suas famílias e impactar também a comunidade" por meio da parceria entre a família e o Estado, na figura das técnicas da UAMA. A sua estratégia para atingir essa meta começa por "fazer vínculo com adolescente", passar curtas e filmes, leva-los a exposições e passeios para "retirá-los um pouco da realidade já conhecida, oferecendo um 'abrir do olhar"”.

Fazê-los ver que há mais do que eles vivem em "seu mundinho" seria, portanto, uma das primeiras estratégias da supervisora para, como entendo, trabalhar no nível de uma escolha pessoal mais bem informada, trazendo à cena mais elementos do que aqueles vivenciados pelos adolescentes em seus contextos sociais. O relato de Regina remete, como entendo, a uma noção de ampliação de um campo de possibilidades dentro dos quais os adolescentes formulariam seus projetos de vida. Segundo Velho (1994), o projeto é o instrumento básico de negociação da realidade do indivíduo com outros autores, indivíduos ou coletivos, ele é meio de comunicação; maneira de expressar e articular interesses, objetivos, sentimentos, aspirações para o mundo e resulta de uma deliberação consciente a partir do campo de possibilidades (circunstâncias) em que está inserido o sujeito, o que implica reconhecer limitações e constrangimentos (VELHO, 1994, p. 103). Assim, parece-me, Regina trabalha numa perspectiva de fazer com que os adolescentes incorporem menos constrangimentos e limitações no momento de enxergarem seu campo de possibilidades e pensarem em seus projetos de vida. A própria experiência de muitos adolescentes em prestação de serviços à comunidade no zoológico, disse-me Regina, mostrou a eles uma outra possibilidade de emprego futuro e mesmo de qualificação profissional que eles não vislumbravam antes: a biologia e a veterinária. 
A viabilidade dos projetos vai depender, diz Velho, do jogo e interação com outros projetos individuais ou coletivos, da natureza e da dinâmica do campo de possibilidades (VELHO, 1994, p. 47). Vale ressaltar que, assim como as pessoas, os projetos mudam e também as pessoas mudam através de seus projetos, ao longo do tempo e de acordo com os contextos. $\mathrm{O}$ autor diz ainda que a consistência do projeto depende da memória, que fornece a consciência do passado, e das circunstâncias do presente, o que permite a elaboração de projetos (VELHO, 1994, p. 101). O projeto e a memória se associam e se articulam ao dar significado à vida e às ações dos indivíduos, ou seja, à própria identidade. Memória (retrospectiva) e projeto (perspectiva) ordenam e dão significado às trajetórias de vida das pessoas (VELHO, 1994, p. 102). A respeito de uma ampliação do campo de possibilidades dos adolescentes, vale mencionar também as tentativas de os profissionais para conseguirem cursos profissionalizantes para os jovens, que seriam mais uma forma de fazê-los enxergar que eles "podem ser outra coisa na vida".

Sobre o papel das medidas socioeducativas, Regina disse que seria o de fazer os jovens refletirem sobre "o existir deles" e então entra o desafio de conseguir "tocá-los a ponto de quererem conversar sobre o assunto". Ela sente que precisa encontrar uma metodologia que de fato toque os adolescentes e, conforme me contou, isso é um desafio, haja vista que geralmente "algo muito grave precisa acontecer para eles acordarem”. Quando me remeto ao termo intervenção, utilizado por ela um pouco acima, ela me diz que 'intervenção não é bem o termo, é melhor dizer 'oportunizar', porque a mudança é ele próprio [o adolescente] que tem que fazer". Nesse sentido, o discurso de Regina parece convergir com o de Clarice, na medida em que responsabiliza de forma mais explícita o adolescente por suas escolhas e o caminho em que ele se encontra. Para alguns, conta-me, o impacto das medidas em suas vidas não é tão grande, eles insistem em dizer "minha vida é no crime, é disso que eu gosto, o que faço de melhor", por outro lado, há relatos de "transformação bastante radical". Regina mencionou, entretanto, que o que ela chamou de "mudança sólida" não é o corriqueiro, mas a alimenta para poder saber que "pode dar certo", isto é, motiva-a para que siga com seu trabalho. O trabalho da equipe técnica, tal como ela o concebe, seria o de "tentar introduzir outros valores" nas vidas dos jovens, que não "os valores da rua e do crime".

Gostaria de trazer à baila, além da noção de indivíduo, central para a compreensão da política das MSE e das falas das técnicas apresentadas acima, uma 
discussão breve sobre formas liberais de governo que, como compreendo, podem ajudar a explicar a visão das profissionais, especialmente no que tange a essa noção corrente de que os adolescentes são livres para fazerem as suas próprias escolhas.

Rose (2006) retoma ideias do liberalismo que vigoraram no século XIX e até meados do século XX para cunhar o que ele vai chamar de "advanced liberal rule", que não visa a governar por meio da sociedade, mas por meio de escolhas reguladas de cidadãos individuais, agora construídos como sujeitos de escolhas e aspirações a autorrealização. Nessa concepção, os indivíduos devem ser governados por meio de sua liberdade, mas não enquanto átomos isolados da política econômica clássica nem como cidadãos da sociedade, mas enquanto membros de comunidades heterogêneas, no momento em que "comunidade" emerge como uma nova forma de conceituar e administrar relações morais entre pessoas.

As estratégias de governo ditas "liberal avançadas" seriam, como pontua Rose, racionalidades animadas pelo desejo de "governar a distância". O "neo-liberalismo", diz o autor, não abandona a vontade de governar, ele mantém a visão de que o fracasso de governo para alcançar seus objetivos deve ser superado pela invenção de novas estratégias de governo que irão ter sucesso. Assim, as estratégias da "advanced liberal rule" podem ser observadas em vários contextos nacionais, diz Rose, em regimes políticos de Esquerda ou de Direita, em relação a campos que vão da saúde ao controle dos crimes. Elas buscam técnicas de governo que criam uma distância entre as decisões das instituições políticas formais e outros atores sociais, concebendo esses atores como sujeitos de responsabilidade, autonomia e escolha e procuram agir sobre eles moldando e utilizando a sua liberdade. $O$ governar se dá à distância por meio da instrumentalização de uma "autonomia regulada".

Nesse contexto, emerge um sujeito de governo que são indivíduos ativos buscando maximizar a sua qualidade de vida por meio de atos de escolha, conferindo a sua vida um significado e um valor na medida em que ela pode ser racionalizada enquanto o resultado de escolhas feitas ou por fazer. Essa racionalidade também foi explorada no trabalho de Schuch (2006), ao estudar práticas restaurativas, destacando a sua relação com a inserção de novos regimes éticos de regulação da vida, como pontuado na introdução dessa dissertação.

Conforme diz Rose, a regulação das condutas se torna uma questão de interesse de cada indivíduo em governar a sua própria conduta de forma livre a serviço da maximização de sua felicidade e autorrealização que eles pensam ser suas, mas tal 
maximização de estilo de vida gera uma relação com a autoridade no mesmo momento em que se pronuncia o resultado de uma "escolha livre". Os indivíduos, nessa lógica liberal avançada, devem se tornar "experts de si mesmos", adotando uma relação instruída e bem informada de cuidado de si em respeito a seus corpos, suas mentes, suas formas de conduta e aquelas dos membros de suas famílias.

Rose faz uma reflexão crítica sobre os programas neo-liberais que reduziram uma série de benefícios para os desempregados e geraram medidas para disciplinar delinquentes e impor responsabilidade sobre eles, desmantelando instituições de bemestar social. Mas esses mesmos programas neoliberais que falam dos sofredores como se eles fossem os autores de sua própria desgraça também faz com que o indivíduo "desavantajado" seja visto como potencialmente e idealmente um agente ativo na fabricação de sua própria existência. Assim, nessa perspectiva, aqueles excluídos dos benefícios de uma vida de escolha e autorrealização não são mais meros apoios passivos de um conjunto de determinações sociais: eles agora são pessoas cujas aspirações de responsabilidade por si e autorrealização tem sido deformadas por uma cultura de dependência, cujos esforços em se realizar têm sido frustrados por tanto tempo que eles sofrem de um desamparo aprendido, cuja autoestima foi destruída. E então, ele identifica o surgimento de uma série de programas para sua reconstrução ética enquanto cidadãos ativos, programas de "empoderamento" para permitir a eles assumir o lugar certo enquanto sujeitos exigentes e autorrealizadores de uma democracia liberal "avançada".

O autor afirma que:

The "freedom" programmed by recent reconfigurations of power and expertise is certainly no simple liberation of subjects from their dreary confinement by the shackles of political power into the sunny uplands of liberty and community. But neither is it merely an ideological fiction or a rhetorical flourish. I have tried to show that the freedom upon which liberal strategies of government depend, and which they instrumentalize in so many diverse ways, is no "natural" property of political subjects, awaiting only the removal of constraints for it to flower forth in forms that will ensure the maximization of economic and social wellbeing. The practices of modern freedom have been constructed out of an arduous, haphazard and contingent concatenation of problematizations, strategies of government and techniques of regulation. This is not to say that our freedom is a sham. It is to say that the agonistic relation between liberty and government is an intrinsic part of what we have come to know as freedom. And thus, I suggest, a key task for intellectual engagement with contemporary relations of power is the critical analysis of these practices of freedom. (ROSE, 2006, p. 159-60) 
A reflexão de Rose acerca de práticas neoliberais de governo, portanto, ajudanos a localizar a compreensão das psicólogas Regina e Clarice. Por outro lado, permitenos problematizar o entendimento dessas profissionais acerca de uma liberdade de escolha pessoal dos sujeitos e também da noção de empoderamento que, segundo elas, dependeria de uma "reflexão de vida mais aprofundada" ou uma "ampliação de consciência”. A reflexão de Rose nos possibilita questionar os termos dessa liberdade e desse empoderamento. Falar de um sujeito mais ativo, portanto, "empoderado e livre para escolher" e não mais "tutelado", como contou-nos Rose, não significa uma simples liberação do sujeito. Isto é, o fomento dessa reflexão também faz parte e se constitui enquanto uma técnica de governo dentro de um enquadramento de uma estratégia liberal de governar. $^{29}$

Anda junto com essa estratégia, ancorada nos princípios de liberdade e autorrealização, a concepção de um indivíduo que faz a autogestão de si, o que Foucault explorou por meio do que ele chamou de "governamentalidade", uma forma de gestão dirigida a indivíduos livres para que possam se autogovernar, uma outra entrada interessante para pensarmos a política pública do sistema socioeducativo, da qual falarei mais adiante.

Conforme afirma Martin (2005), a partir de sua pesquisa etnográfica com administradores de recursos humanos em corporações americanas, há dois conceitos de policy que andam juntos, o primeiro pensado como administração civil e governo e o segundo que se localiza na ideia de "refinamento, educação, polimento e cultivo", sendo que em ambos os sentidos subjaz uma preocupação com a ordem social, seja no nível das grandes instituições, no caso da primeira definição de "policy", seja no nível de pessoas individuais, como no caso da segunda definição da palavra "policy". Ele percebe nos Estados Unidos que formas contemporâneas de administração civil estão sendo alcançadas por meio de "policies” que encorajam a fusão desses dois níveis, isto é, indivíduos começam a "se administrar" de modo que eles continuarão a mudar e melhorar nos campos da saúde e do trabalho. Essa "autogestão de si" devota ao "melhoramento contínuo" está se tornando o meio pelo qual a sobrevivência da nação, da corporação e pessoa será realizada (p. 183). O desafio para entender as "policies"/políticas de "auto-gestão" é aparente quando consideramos o seu

\footnotetext{
29 No limite, podemos questionar, portanto, até que ponto seria possível que fossem desenvolvidas políticas públicas que não fossem de alguma forma "tutelares" e que fossem completamente emancipadoras dos sujeitos.
} 
relacionamento com várias formas de poder. $\mathrm{Na}$ autogestão, o gestor de alguma forma se torna "internalizado": controles impostos externamente se tornam motivação gerada internamente - quase numa lógica de um "processo civilizador" contemporâneo (ELIAS, 1991).

Ainda dentro dessa perspectiva e retomando novamente o entendimento de Regina, supervisora da unidade acerca do seu trabalho com os adolescentes, vale mencionar a experiência que o zoológico vem tendo enquanto instituição que recebe adolescentes que devem prestar serviços à comunidade. Os jovens em PSC têm tutores e fazem trabalhos diversos no zoológico. Um deles, em especial, é citado por Regina como sendo capaz de surtir bons efeitos nos adolescentes: o que se refere ao cuidado com os animais. Para Regina, além desse cuidado despertar neles o interesse pelos bichos e fazê-los pensar em cursar biologia e veterinária, ele tem o mérito de fazer com que, nas palavras da supervisora, "ao cuidarem de um outro, tenham vontade de cuidar de si mesmos". Assim, parece que a analogia entre o cuidado com um outro, o animal, nesse caso, faz com que os jovens reflitam sobre o cuidado com eles próprios e assim despertem para mudanças de atitude que envolvem uma melhor gestão de si. A transformação das condutas nesse sentido também é mencionada quando os adolescentes se tornam pais ou mães, em que o cuidado com os filhos "os chama para a responsabilização".

Em sua dissertação de mestrado sobre a implantação de uma política pública para enfrentar a violência intrafamiliar em Bogotá, Colômbia, Marco Martínez-Moreno (2013) desenvolve a noção de mudança social induzida a partir de uma política pública e o caráter "civilizatório" que a função das leis e políticas parecem ter no que tange aos comportamentos daqueles que estão sujeitos a elas, aludindo também à noção exposta acima, de um auto-regulação das condutas relacionada à expansão de uma racionalidade neoliberal. Ele percebe ainda uma tensão entre as moralidades de agentes públicos e as das pessoas às quais a norma e a política pública se aplicam. Martínez-Moreno fala da família como domínio de intervenção para produzir um novo cidadão, no âmbito de uma política pública centrada na garantia de direitos, o que também parece algo relevante no caso dos meninos em medida socioeducativa. A transformação dos sujeitos passaria, tal como Martínez-Moreno expôs e como percebo no caso em estudo, pela alteração das subjetividades e teria também a família como grande aliada nesse processo. 
No que tange à preocupação com a transformação, a supervisora Regina contoume que a mudança ocorre a partir de marcos que ela chama de objetivos, que seriam os de frequentar a escola e trabalhar, e o que ela chamou de marcos "subjetivos" da política que dizem respeito à abertura de "portas e janelas para fazer a realidade ser transformada, para que ele possa fazer sentido na vida dele [do adolescente]”. Na verdade, tal como ela entende, deve haver uma intervenção mais subjetiva, de valores, para que se concretizem de fato os "marcos objetivos" das MSE. A consequência de uma reflexão mais aprofundada sobre a vida é atingir esses marcos objetivos e "empoderar as pessoas".

A intervenção subjetiva aliada a políticas com "melhor olhar" seriam capazes de gerar mudança de significado da vida do adolescente. Pensar a alteração da subjetividade dos jovens também se conecta com a preocupação frequente dos profissionais no que diz respeito às medidas socioeducativas fazerem "sentido" para os adolescentes. Estes precisariam entender ainda a "responsabilização por viver numa sociedade e no que isso implica", conforme Regina. As MSE teriam que ser a um só tempo punitivas e educativas.

A respeito dos tipos de profissional mencionados por Regina (ver capítulo 2), acolhedores, por um lado, e pessoas mais firmes e disciplinares, por outro, cumpre mencionar outra situação etnográfica em que, mais uma vez, diferentes visões sobre as técnicas para a transformação dos adolescentes apareceu. Trata-se da experiência de uma oficina, conduzida pelas profissionais da UAMA, com os responsáveis legais dos adolescentes atendidos na Unidade. Regina havia me explicado que o agendamento dessa oficina tinha o intuito de proporcionar uma ocasião para que ela conhecesse os responsáveis legais dos jovens, uma vez que era novata da unidade, e também aproveitasse para que ficassem claros os limites de atuação das profissionais, fazendo com que o trabalho fosse compreendido enquanto uma parceira adolescentes-famíliaEstado (este última na figura das técnicas da UAMA). Conforme me contou, um dos problemas principais das famílias atendidas é a perda de autoridade dos pais frente aos filhos, o que leva a grandes demandas aos profissionais por exercerem essa autoridade.

A oficina consistiu de três dinâmicas: primeiro, todos se apresentaram e fizeram uma espécie de relaxamento corporal, comandado pela psicóloga Clarice; em seguida, eram erguidas placas com alguns dizeres pelas profissionais da UAMA, que haviam sido construídas, conforme explicado, com base nas falas mais comuns dos pais às profissionais durante os atendimentos; os presentes deveriam levantar a mão caso se 
identificassem com as frases expostas; por fim, foi feito um círculo por meio da pressão que um corpo exercia sobre os demais, os braços deviam se encostar e se sustentar para que isso fosse possível, o que foi feito para demonstrar mais uma vez o caráter de grupo de apoio que aquele espaço visava a criar e de que eram todos parceiros trabalhando por um ideal comum.

Em certo momento durante a oficina, quando foi erguida a placa com uma frase sobre a prestação de serviços à comunidade, a supervisora Regina explicou o seu funcionamento, sinalizando que ela é uma medida judicial e que "seria boa para os meninos aprenderem regras, horários, postura e comportamentos". Além disso, mencionou, a PSC também funciona no sentido de os adolescentes repararem o dano que causaram à sociedade e que isso lembra a eles de sua "responsabilidade".

Mesmo assim, um pai estava muito descontente durante a oficina e não parava de repetir que "o sistema era falho". Em determinado momento, ele levanta a mão e a voz e pergunta para a psicóloga Clarice se ela não tem como chamar o juiz para ele conversar com o seu filho para que o menino sinta que está sendo vigiado e monitorado.

Clarice responde que o fato de o filho do senhor em questão não ter sido chamado pelo juiz seria uma coisa boa, por significar que o filho dele estava cumprindo a medida "direitinho". Clarice diz também ao pai que o profissional da UAMA é o vigia, pois são os profissionais que passam as informações dos adolescentes ao juiz.

Mas o pai continua: "acho que chocaria melhor, funcionaria melhor se o juiz chamasse. Acho que a coisa tá muito solta, não gosto de coisa liberal demais, quero que ele pague."

A supervisora Regina intervém e diz: “devemos lembrar que estamos em uma UAMA, que eles estão em liberdade. Agora o Estado está entrando na vida dos adolescentes e isso já é uma consequência, é uma pessoa de fora te chamando a atenção".

O pai continua: "quero que eles sejam cobrados e que paguem pela atitude deles, mas não gosto muito de conversar, ele fala que 'não dá nada', 'dá vontade de sentar a ..."

A psicóloga Clarice intervém e diz: "a gente quer salvar o filho do mundo e tem hora que temos limites e que ele vai ter que fazer as escolhas dele".

A assistente social Aline apoia Clarice dizendo: "ai como eu queria que a minha filha escolhesse certas coisas para a vida dela, mas às vezes ela não quer, mas é assim 
mesmo, ela é que vai fazer as escolhas para a vida dela, mesmo a gente achando as vezes que sabe o que é melhor pra eles..."

O pai prossegue: "quero fazer ele entender que ele é o responsável pelos atos dele. A mãe dele mesmo nunca pode vir aqui na UAMA, sempre diz que tem problema com o trabalho, não tem como obrigar a mãe a vir não?"

Ao que a psicóloga Clarice responde: "as pessoas só conseguem dar o que dão conta, cada pessoa tem o seu limite".

A partir do diálogo transcrito acima, fica evidente que o modelo pelo qual opera o pai do adolescente se baseia em princípios mais hierárquicos, disciplinadores pela vigilância, repressores e tutelares, ao passo que o modelo que estava sendo explicado pelas profissionais é pautado por uma lógica individualista que vê os sujeitos como indivíduos livres para escolher, ainda que precisem ser orientados para isso, como fica claro em outros momentos.

A visão das técnicas, em especial de Regina e de Clarice, contrasta com uma visão mais repressiva e tutelar proferida por Rafael e descrita no capítulo anterior, quando ele afirma que o "sistema socioeducativo está ao contrário", uma vez que acredita que os jovens devem ser internados no início de sua trajetória infracional, pois precisariam ser "parados" logo para que seja mais fácil "reverter o processo". Conforme expressou Rafael, os jovens deveriam ir para a internação primeiro, antes das medidas em meio aberto, para que se tornassem mais maduros e então aptos a fazerem suas próprias escolhas de vida.

Ficou evidente, quando Rafael esboçou sua opinião acerca do sistema socioeducativo, que algumas técnicas pensavam como Rafael, uma especial, uma ATRS, concordou na hora de que o sistema estava ao contrário e se mostrou muito emocionada com o fato de ter acontecido uma reza de mãos dadas após a palestra conduzida por Rafael. Assim, o adolescente só poderia exercer mesmo a sua escolha enquanto indivíduo após ser visto como tal, ou seja, após atravessar essa fase complicada da adolescência e estar finalmente preparado para tomar as rédeas de sua vida, numa perspectiva mais individualista.

Para discutir esse contraste entre as visões acerca da maneira como administrar os adolescentes em medidas socioeducativas, resgato Foucault, citado por Martin (MARTIN, 2005, p. 184-5): 
To go further we need to consider the various sorts of power that might operate in relation to policies. In the Classical age, as Foucault describes it, power was exerted by the sovereign through repressive legal codes and the force of the state apparatus. Punishment was wrought on the very body of the criminal, as in the opening scenes of Discipline and Punish where a prisoner's body is slowly pulled to pieces by teams of horses (Foucault 1979). In contrast, with the coming of modern power, gossamer microcontrols that hold the body in time and space arise in a multitude of contexts: prisons, hospitals, schools, the military, the factory. Docile bodies are produced through the gaze of the prison managers in the Panopticon, or the disciplinary gaze and questions of the therapist, doctor, sociologist or demographer. Modern power, bio-politics, arose together with, or as Foucault puts it, consubstantial with, changes in the economy and polity involved in the rise of the self-affirmation of the bourgeoisie. As the bourgeoisie came into its own, its self-definition was based in part on knowledge of the populations of the nation states of which it was the core: their size, rate of growth, health, composition. The inherited 'pure' blood of the aristocracy of the classical era gave way to the 'normal' healthy blood, body, brains and brawn of the bourgeoisie (Foucault 1980a: 125-6).

The process of normalization lies at the heart of how modern power operates: the 'normalizing gaze...establishes over individuals a visibility through which one differentiates them and judges them' (Foucault 1979:184).

Mencionando Foucault, Martin nos lembra que os tipos de poder surgem consubstancialmente com importantes mudanças na natureza da economia e dos regimes políticos. Ele instiga-nos dizendo que talvez a noção de "corpos dóceis" mantidos de forma muito controlada em termos de tempo e espaço pelo olhar disciplinar tem mais a ver com a dominância de instituições totais e sistemas de produção em massa característicos de até meados do século XX. Ele se pergunta, então, sobre o que virá em seguida e se a emergência de políticas que encorajam a autogestão depende de um tipo de poder que vai além da noção de "corpos dóceis".

A obra "Segurança, Território, População", de edição original de 2004 e brasileira de 2008, abriga cursos que Foucault ministra no Collège de France. Alguns textos interessam ao âmbito desse trabalho por possibilitarem a compreensão de uma preocupação central para as políticas públicas, a saber, a "população", e por discutirem, como é próprio da abordagem Foucaultiana, tecnologias e dispositivos, nesse caso, relacionados à atuação do governo contemporâneo. A história que ele recupera é importante para a compreensão da emergência de uma arte e uma ciência de governo, nas quais se inserem as tecnologias políticas e certos mecanismos de poder, que são balizadas por determinadas categorias que lhes são centrais.

Foucault dá exemplos acerca da problemática da criminalidade a partir do que ele chama dos três mecanismos de poder. Para compreender a forma de se abordar a criminalidade por essas três vias, ele nos fala das atitudes que são tomadas no seio de 
uma sociedade quando da ocorrência de um ato desse tipo, como o roubo. A primeira forma consiste em se criar uma lei e estabelecer uma punição para os que a infringem, é o "sistema do código legal com divisão binária entre o permitido e o proibido" [...], há um "acoplamento entre um tipo de ação proibida e um tipo de punição". É o mecanismo legal ou jurídico. O segundo mecanismo é o disciplinador, a "lei enquadrada por mecanismos de vigilância e de correção", permeado por uma série de "técnicas adjacentes, policiais, médicas, psicológicas, que são do domínio da vigilância, do diagnóstico, da eventual transformação dos indivíduos" (2008, p. 8). O terceiro mecanismo é o de segurança, que é a forma que caracterizaria o que o autor chama de “dispositivo de segurança" (p. 8). Sob a ótica dos "dispositivos de segurança”, o roubo é inserido numa série de acontecimentos prováveis e as reações a ele são inseridas num "cálculo de custo", fixando uma média considerada ótima e depois estabelecendo os limites do aceitável, além dos quais não se deve ir. (p. 9). Ele nos alerta, entretanto, que não há a era do legal, a era do disciplinar e a era da segurança do ponto de vista de uma sequencia histórica, uma vez que esses três mecanismos coexistem e não são excludentes. Não é que os mecanismos de segurança tomam o lugar dos mecanismos disciplinadores, os quais teriam tomado o lugar dos mecanismos jurídico-legais. O que muda são as próprias técnicas que vão se aperfeiçoar ou se complicar, mas o principal, diz o autor, é o que vai mudar no sistema de correlação entre os mecanismos jurídicolegais, os mecanismos disciplinares e os mecanismos de segurança (p. 11).

A noção de população, chave para a compreensão das práticas de governo que Foucault descreve e que contemporaneamente ainda ocorrem, aparece no século XVIII conectada a uma mortalidade dramática, não sendo colocada a questão da população em sua positividade e generalidade (p. 89). Para os mercantilistas do século XVII a população aparece no princípio da dinâmica do poder do Estado e do Soberano, porque garante no interior do próprio Estado uma grande concorrência entre a mão-de-obra possível, assegurando salários baixos e, logo, baixo preço das mercadorias, possibilitando a sua exportação, o que, por sua vez, representava nova garantia de poder, novo princípio para o próprio poder do Estado (p. 90). A população nessa época era vista essencialmente como força produtiva e devia ser adestrada, repartida, distribuída e fixada de acordo com mecanismos disciplinares para cumprirem devidamente com seu papel enquanto fonte de riqueza e poder. O problema da população era assim considerado pelos mercantilistas no eixo do soberano e dos súditos (p. 91). 
No século XVIII, com os físiocratas, a população para de aparecer como uma coleção de súditos de direito e de vontades submetidas às vontades do soberano e passa a ser considerada um conjunto de processos que é preciso administrar no que têm de natural e a partir do que têm de natural (p. 92), de onde se desdobrará a noção de "biopoder". A partir desse momento, portanto, compreende-se que:

[não se trata de obter] a obediência dos súditos em relação à vontade do soberano, mas de atuar sobre coisas aparentemente distantes da população, mas que se sabe, por cálculo, análise e reflexão, que podem efetivamente atuar sobre a população. É essa naturalidade penetrável da população que [...] faz que tenhamos aqui uma mutação importantíssima na organização e na racionalização dos métodos de poder (p. 95).

"A população é, portanto, de um lado, a espécie humana e, de outro, o que se chama de público", fazendo esse último conceito alusão às opiniões, maneiras de fazer, comportamentos, hábitos, temores, preconceitos, exigências da população - aquilo que se age por meio da educação, das campanhas, dos convencimentos (p. 99). Para Foucault, o problema político moderno está ligado à população (p. 99). Ele compara o poder pastoral com o poder no governo das populações na medida em que ambos seriam exercido mais sobre uma multiplicidade do que sobre um território, apesar de este não ter desaparecido por completo do horizonte do governo de populações.

Em outra obra, Foucault (1991) traz um apanhado histórico acerca do governo como um problema geral, o que só teria aparecido no século XVI. A questão essencial no estabelecimento da arte de governo no século XVI e que assim permanece até por volta do século XVIII, fala-nos Foucault, é a introdução da economia na prática política (1991, p. 92). Ele vai retomar uma literatura que estava preocupada em pensar como introduzir a economia que era entendida como a forma correta de administrar indivíduos, bens e riqueza dentro da família e de fazer a fortuna da família prosperar, portanto, uma economia no sentido doméstico, familiar, na prática política. Governar um estado, diz, vai significar aplicar uma economia ao nível de um estado inteiro, que significa exercer frente aos seus habitantes e à riqueza e comportamento de todos e cada um uma forma de vigilância e controle tão atenta quando aquela do chefe de uma família sobre seu domicílio e bens. Foucault cita o mercantilismo como a primeira racionalização do exercício de poder como uma prática de governo; pela primeira vez com o mercantilismo se vê o desenvolvimento de um saber de estado que pode ser usado como uma tática de governo (p. 97-8). 
Como o autor nos mostra, a teoria de governo era ligada a um modelo de família, que claramente se mostrou inapto a responder adequadamente à importância das posses territoriais e a finanças reais (p. 98). Uma série de processos permitiram a emergência da arte do governo e a superação dos obstáculos que o modelo antigo apresentava, a exemplo da expansão demográfica do século XVIII, conectada com uma abundância crescente de dinheiro, ligada a uma expansão da produção agrícola (p. 98). Foi com o desenvolvimento da ciência de governo que a noção de economia como uma de suas instâncias veio a ser caracterizada como hoje a compreendemos e foi por meio dessa ciência que se tornou possível a identificação dos problemas específicos da população (p. 99). A família, a partir de então, emerge como um elemento da população e um instrumento fundamental do governo de populações (p. 99) e perde seu lugar enquanto modelo para a ação de um governo que se preocupa com uma administração de maior escala, isto é, de uma população. Antes da emergência da população era impossível conceber a arte de governo a não ser no modelo da família, em termos de economia concebida como a administração de uma família; do momento em que, ao contrário, a população aparece absolutamente irredutível à família, a última se torna de importância secundária comparada à população e vira um elemento interno a ela (p. 99). A família, então, deixa de ser um modelo e passa a ser um segmento. Entretanto, um segmento privilegiado porque quando alguma informação que concirna a população é requerida (comportamento sexual, demografia, consumo, etc), ela tem que ser obtida por meio da família. Mas a família se torna um instrumento ao invés de um modelo: o modelo privilegiado para o governo de população, mas não o modelo quimérico de bom governo.

É a partir da metade do século XVIII que a família aparece nessa dimensão de instrumentalidade relativa à população, com a instituição de campanhas para reduzir mortalidade e promover casamentos e vacinação, por exemplo. Então, o que torna possível ao tema da população desbloquear o campo da arte de governo é essa eliminação da família como modelo. Em segundo lugar, a família começa a aparecer acima de tudo como o fim último do governo. Em contraste com a soberania, o governo agora tem seu propósito não no ato de governar em si, mas no bem-estar de sua população (p. 99-100), o que justifica uma série de intervenções.

Quando Foucault discute a problemática do que ele chama dessa sociedade de governo, ele deixa claro que não se trata de uma substituição dos demais modelos de sociedade que ele estuda em outras obras. A sociedade da soberania e a sociedade 
disciplinar não são substituídas pela sociedade de governo, em realidade, existe um triângulo, diz ele, constituído por soberania-disciplina-governo, que tem como seu alvo primeiro a população e tem os aparatos de segurança como seu mecanismo essencial. Viveríamos, como ele diz, na era da "governamentalidade" e o Estado só poderia ser entendido em sua "sobrevivência e limites" com base nas táticas gerais de governamentalidade (p. 101).

Foucault faz uma categorização de três tipos de estado: o de justiça, nascido no regime territorial de tipo feudal que corresponde à sociedade de leis (escritas ou costumes); o estado administrativo, nascido na territorialidade de fronteiras nacionais nos séculos XV e XVI e correspondente a uma sociedade de regulação e disciplina; e, finalmente, um estado governamental, essencialmente definido não mais em termos de sua territorialidade, de sua área de superfície, mas em termos da massa de sua população com seu volume e densidade, e com o território sobre o qual ela está distribuída, embora aqui o território figure apenas como mais um de seus elementos componentes. Esse estado de governo que incide essencialmente sobre população e se refere e faz uso do instrumentação do saber econômico (aqui no sentido de "economics" - esfera própria desse governo e não no sentido lato de "economia" como "economy") poderia ser visto como correspondente a um tipo de sociedade controlada por aparatos de segurança (p. 104).

A partir da leitura Foucaultiana, podemos entender que numa mesma sociedade operam mecanismos diversos. Assim também pareceu o caso dos adolescentes que cumprem medidas socioeducativas na UAMA. Se por um lado, atuam sobre eles alguns mecanismos de vigilância e disciplinadores, por meio, por exemplo, da obrigatoriedade da frequência escolar e do envolvimento em atividades profissionais, espaços que, inclusive, produzem "corpos dóceis", tem-se um discurso de que o adolescente que comparece à UAMA é livre para fazer as suas escolhas e que deve ir a UAMA para ser orientado e não propriamente punido, uma vez que a punição, conforme me disseram as técnicas, parece ser, na cabeça dos jovens, algo muito mais severo do que aquilo que se passa no contexto da UAMA, que não consiste em um aprisionamento dos corpos, por exemplo, mas sim de uma série de diálogos que são estabelecidos com eles e as suas famílias $^{30}$. Além disso, há o discurso corrente de que nada pode, de fato, obrigar o

\footnotetext{
${ }^{30}$ Para pensar uma forma de ação tutelar do Estado brasileiro, ver "Um grande cerco de paz: poder tutelar, indianidade e formação do Estado no Brasil”, do autor Antonio Carlos de Souza Lima (1995). Ao tratar da questão indígena no Brasil, Souza Lima fala do poder tutelar do Estado como forma de
} 
adolescente a frequentar os atendimentos e que, portanto, essa decisão teria um quê de "voluntariedade", haja vista que, ao fim e ao cabo, dificilmente as faltas levariam a consequências graves para os adolescentes. O que podemos apreender da leitura de Foucault sobre as técnicas contemporâneas de governo é que a própria vontade de mudança de valores, conforme disse-me Regina, que ensejaria uma mudança comportamental (a dos marcos objetivos da política) está também inserida numa lógica de governo "à distância", que inculca nos indivíduos uma noção específica de gestão de suas vidas que interessa ao Estado e a seus processos de normalização.

Do modo como exposto por Regina, por exemplo, fica claro que a medida deve abrir espaço para que sejam trabalhados significados, uma reflexão mais aprofundada e o sentido do trabalho e só quando esse é verdadeiramente compreendido e internalizado pelos adolescentes é que pode haver mudança. O comprometimento, fala ela, é que faz dar certo. A medida tem que ser um misto de responsabilização com acolhimento, tem que ser entendida como uma penalidade, mas também como uma possibilidade de mudança. A escola e o trabalho nesse sentido seriam "aspectos formais" das medidas que "chamam para a responsabilização". Percebe-se, então, em seu discurso, a linha tênue entre uma punição em sentido mais repressivo e o entendimento de que o meio em que eles vivem não lhes mostraria todas as possibilidades para suas vidas e que, portanto, o profissional não deveria apenas ter o pulso firme e repreender o jovem, mas também lhe proporcionar um abrir do olhar que fosse capaz de fazê-los enxergar as boas opções de vida, as quais eles deveriam escolher. A transformação, portanto, dependeria, sobretudo, de uma mudança subjetiva, de valores, que fizesse com que os jovens vissem sentido nos marcos objetivos que as medidas socioeducativas impõem aos adolescentes.

Os processos de modernização, - ou, como prefere Elias (ELIAS, 1939 [1990]), o "processo civilizador" - que moldaram as sociedades modernas ocidentais como as conhecemos hoje, têm ocorrido desde a Idade Média. Aos poucos, uma subjetividade moderna foi sendo construída e a própria ideia de indivíduo, tão importante para as legislações que se têm hoje no mundo todo, foi tomando corpo. Uma outra transformação importante de moralidade na modernidade foi a mudança de valores e práticas ocasionadas pela emergência do conceito de dignidade, da qual falam Taylor

\footnotetext{
"sedentarizar" os povos indígenas a partir de ações sobre suas ações e não da violência. O poder tutelar aparece, em Souza Lima como integrando tanto elementos das sociedades de soberania quanto das disciplinares, haja vista que ele incide tanto sobre a ação dos povos nativos quanto sobre os seus territórios. O poder tutelar no caso descrito e analisado por Souza Lima se refere à inclusão de populações e terras numa rede nacional de vigilância e controle, a partir de um centro único de poder.
} 
(1997) e Berger (1983). Esses dois autores, a partir de perspectivas diferentes que explorarei adiante, mostram como o conceito de dignidade foi sendo moldado, a importância que tomou na modernidade e, ainda, de que forma ele se relaciona com outros conceitos, como o de honra (BERGER, 1983) e de indivíduo, explorado na obra de Dumont (DUMONT, 1983), intitulada "Ensaios sobre o individualismo",

Segundo artigo de Berger intitulado "Sobre a obsolescência do conceito de honra" (BERGER, 1983) e já mencionado no início desta dissertação, seria possível compararmos a posição ocupada pelo conceito de honra em seus usos contemporâneos àquela ocupada pelo conceito de castidade, pois ambos são conceitos ultrapassados na filosofia de vida da modernidade (p.172). O autor argumenta que a maior parte de nossos contemporâneos tem dificuldade em entender o insulto, que é, em essência, um ataque à honra. Essa forma de "prejuízo" a outrem, diz, parece não ter muito espaço na consciência moderna e na legislação moderna estadunidense, que está em consonância com essa mentalidade moderna (p.172). Desse modo, motivações que apelem para a honra não têm legitimidade na legislação americana e legislações que ainda as admitem são consideradas arcaicas. Às vezes, a parte insultada pode conseguir provar dano material ou alegar dano psíquico, mas isso também está longe da noção de ofensa contra a honra. Nos casos em que esses danos não ocorrem, a própria realidade da ofensa é negada. Na situação da manutenção dessa acusação de ofensa nesses casos, o acusador geralmente é taxado por adjetivos psiquiátricos, como "neurótico" ou então em termos de atraso cultural, como "mentalidade provinciana". Na realidade, Berger tenta nos mostrar que há uma negação contemporânea da realidade da honra e das ofensas contra a honra (p. 173).

Para melhor se compreender a questão da obsolescência do conceito, o autor o compara com o conceito de dignidade, mostrando que este vem tomando o lugar daquele na mentalidade moderna. Há quem interprete a decadência do conceito de honra como um enrijecimento moral, como uma diminuição do respeito pelas pessoas e uma desumanização, mas deve-se considerar que estamos em uma época de ascensão de novas moralidades e de um novo humanismo, além de estarmos em um momento de grande preocupação com a dignidade e os direitos dos indivíduos. Falar de direitos do indivíduo também pressupõe a decadência da noção de "honra da casa" ou da família e a ascensão do indivíduo como valor principal na sociedade moderna. No que concerne essa questão, Dumont nos explica o processo que fez do indivíduo uma ideia-valor central na modernidade. Vê-se, a partir da análise do autor, que o indivíduo que antes 
era apenas concebido como fora do mundo vai se transformar no moderno "indivíduono-mundo", à medida que o holismo desaparece da representação das sociedades ocidentais, fazendo florescer, na consciência moderna, a atribuição do valor, de maneira predominante, ao indivíduo (DUMONT, 1983).

De acordo com Berger, "o mesmo homem moderno que tem dificuldade em compreender uma questão de honra está disposto a reconhecer as demandas por dignidade e direitos iguais por quase todo novo grupo que as faz" (BERGER, 1983, p.173), como as de minorias raciais, religiosas, classes exploradas, pobres, desviantes, etc. Assim, não devemos pensar o problema em termos de um "pessimismo ético", mas sim nos preocuparmos em definir o que é honra e o que é dignidade, e o que a substituição de um pelo outro pode nos ensinar acerca da mentalidade moderna.

A honra, conta-nos o autor, é normalmente entendida como um conceito aristocrático e ligado a um tipo de sociedade pensada em termos de ordem hierárquica (p. 174). As noções ocidentais teriam sido influenciadas por códigos medievais da cavalaria, cujas raízes residem nas estruturas sociais do feudalismo e que sobreviveram melhor nos grupos que ainda têm uma visão mais hierarquizada da sociedade, a exemplo de algumas classes como a nobreza, a militar e a dos profissionais tradicionais, da medicina e do direito. Para esses grupos, a honra é uma expressão direta de status e fonte de solidariedade entre aqueles socialmente iguais, além de se constituir em uma linha que os separa dos que são socialmente inferiores. Vê-se, portanto, que a honra prescreve certas qualidades que fornecem a conexão entre o indivíduo e a comunidade e, mais do que isso, entre esse indivíduo e as normas idealizadas da comunidade, de modo que a desonra se constitui, inversamente à honra, de uma perda de prestígio na comunidade, bem como da perda do self, visto que a própria existência está relacionada a certos padrões arquetípicos de comportamento.

Aos poucos, os códigos medievais de honra foram declinando, mas antes de desaparecem completamente e antes que a honra se tornasse um conceito desprovido de sentido, tal como a contemporaneidade o entende, houve um processo de emburguesamento da honra, antes prerrogativa apenas da nobreza, por um processo de modernização, ou civilizador, nos termos de Elias (1993). Entretanto, foi ainda com a ascensão da burguesia e de seus intelectuais críticos que a honra do Ancien Régime e seus protótipos hierárquicos foram perdendo força, bem como também, nesse momento, emergiu um entendimento do homem e da sociedade que desembocaria no aniquilamento de qualquer conceituação de honra (BERGER, 1983, p. 175). 
É preciso que compreendamos que, para a consciência moderna, é o self solitário, o indivíduo, independentemente da classe a que pertença ou dos atributos que carregue, que tem sido percebido como portador de dignidade humana e de direitos humanos inalienáveis (p.176). A dignidade, ao contrário da honra, relaciona-se sempre à humanidade intrínseca e alienada das normas e papéis impostos socialmente ao indivíduo e que independe de sua posição na sociedade. Um exemplo fornecido pelo autor são as formulações clássicas dos direitos humanos, tal como o preâmbulo à declaração de independência estadunidense e à Declaração Universal dos Direitos Humanos das Nações Unidas. Entende-se que esses direitos sempre pertenceram aos indivíduos independentemente de sua raça, cor ou credo, sexo, idade, condição física ou status. Existe, a esse respeito, uma sociologia implícita que concebe as diferenças biológicas e históricas entre os homens como irreais ou irrelevantes e uma antropologia implícita que localiza a verdadeira identidade para além ou acima dessas diferenças (p.176).

Tanto o conceito de honra quanto o conceito de dignidade constroem uma ponte entre o indivíduo e a sociedade, de modo que é na relação com outras pessoas que os dois conceitos são atingidos, trocados, mantidos ou ameaçados. Honra e dignidade são objetivos de um empreendimento moral, carecendo de um esforço deliberado para a sua manutenção. A diferença é que o conceito de honra implica que a identidade (ou self) esteja ancorada em papéis institucionais, ao passo que o conceito moderno de dignidade implica em uma identidade essencialmente independente de tais papéis (p. 177).

Em um mundo governado pela noção de honra, a verdadeira identidade do indivíduo reside em seus papéis sociais, assim, para um cavaleiro, por exemplo, que cumpre seu papel cavalgando para ir à batalha, deixar esse papel é deixar a si mesmo. Por outro lado, em um mundo onde prevalece o conceito da dignidade, o indivíduo só pode descobrir sua verdadeira identidade se ele se emancipa dessas máscaras que constituem os papéis sociais, que lhes são impostos pela sociedade. Também a relação desses dois "mundos" com a história é diferente. No da honra, a identidade se encontra conectada ao passado e a participação do indivíduo na história se dá por meio de seu desempenho nos seus papéis institucionais, que o possibilitam fazer parte da história de uma instituição em particular e da sua sociedade como um todo. $\mathrm{O}$ descolamento maior que existe na modernidade entre os papéis institucionais e o processo de construção do self também se reflete nessa concepção de participação na história. Nesse sentido, o 
autor diz que por esse motivo a consciência moderna tenderia para uma curiosa "ahistoricidade" (p.177).

Os fatores que contribuíram para a transformação moral observada foram múltiplos: tecnologia e industrialização, burocracia, urbanização e crescimento populacional, melhorias na comunicação, na mobilidade social, entre outros. Essa situação resulta no que Arnold Gehlen, citado por Berger, caracterizou como “desinstitucionalização" e "subjetivação". A "desinstitucionalização" se refere a um enfraquecimento do poder das instituições frente ao indivíduo, que agora precisa usar sua própria subjetividade como fonte de estabilidade e significado, dos quais ele necessita para viver (p.178).

O homem é, não obstante, um ser intrinsecamente sociável e cuja identidade só pode emergir num contexto social estável, de modo que na contemporaneidade há uma grande incerteza a respeito da identidade - a crise da identidade na modernidade. A honra aparece em um mundo de instituições relativamente intactas e estáveis, fazendo sentido apenas nesse mundo em que os indivíduos podem ancorar as suas identidades a papéis sociais designados pela sociedade. As forças da modernidade fizeram esse mundo se desintegrar, tornando a honra um conceito sem importância e proporcionando uma situação para a redefinição da identidade e da dignidade intrínseca, algo descolado dos papéis institucionais por meio dos quais o indivíduo se expressa na sociedade, e que pode até mesmo, em alguns casos, ir contra eles. Na modernidade, as instituições deixam de ser a casa do self, da identidade, e ao invés disso, elas se tornam realidades opressoras.

Algumas perspectivas entendem a desintegração das instituições como um estágio necessário para que se alcance a liberdade, embora traga uma ameaça de caos social e psíquico. Perspectivas mais conservadoras, por sua vez, veem-na como uma patologia dos tempos modernos, como uma perda de estruturas que, na verdade, permitiriam ao homem ser ele mesmo e ser livre (BERGER, 1983, p.180). A primeira visão falha ao não levar em consideração uma necessidade fundamental para o homem, que é a de ordem, sem a qual indivíduos e coletividades poderiam acabar em um caos "desumanizante". O lado de direita - o lado nostálgico - desconsidera as conquistas morais que foram possíveis graças a essa transformação: a descoberta da autonomia individual, com uma dignidade sendo derivada de seu ser acima e para além de qualquer identificação social; descobertas de dignidade e direitos humanos; a convicção de que mesmo os membros mais fracos da sociedade têm um direito inerente à proteção e 
dignidade; a proscrição da escravidão e da opressão étnica e racial; a descoberta da dignidade e dos direitos das crianças; a nova sensibilidade à crueldade das guerras, torturas e genocídios; o reconhecimento da responsabilidade individual para todas as ações, mesmo àqueles com papéis institucionais específicos, etc. (p. 180). O autor afirma que a questão que se impõe diante dessa situação é a de saber como as instituições do futuro serão constituídas e se elas vão ter sucesso no processo de incorporação dessas conquistas que se referem à dignidade humana, que seriam, segundo ele, as mais importantes do homem moderno (p. 181).

A esse respeito, Luís Roberto Cardoso de Oliveira (2004) cita que a transformação de honra em dignidade se desdobrou em uma articulação entre o processo de expansão dos direitos de cidadania e as demandas por reconhecimento, o que trouxe à tona questões que não podem ser adequadamente compreendidas por meio de uma abordagem que se volte apenas para o exame do conflito de interesses ou apenas para os direitos humanos como princípios absolutos. $\mathrm{O}$ autor traz alguns exemplos de situações ocorridas no âmbito de juizados especiais para pensar o conjunto de direitos que se situam na intersecção entre os universos da legalidade e da moralidade e que versam sobre atos ou relações que, como entende, teriam um caráter "desde sempre recíproco". Isto é, atos cuja manifestação empírica supõe uma sintonização de pontos de vista entre os atores, cujo principal instrumento seria a dádiva, por meio da qual interações entre atores ganhariam substância e os processos que as caracterizam ganhariam sentido.

$\mathrm{O}$ autor fala em dádiva ao pensar o conflito na medida em que entende que a importância do elo social e do caráter dialógico das relações entre litigantes nas situações que analisa. Ele argumenta que as trocas, ou obrigações de dar, receber e retribuir que Mauss examina, simbolizam não só afirmação dos direitos das partes envolvidas, mas o reconhecimento mútuo da dignidade dos parceiros, "cujo mérito ou valor para participar da relação seria formalmente aceito". A questão residiria, como desenvolve o autor, na negação da dádiva, que muitas vezes não pode ser traduzida em evidências materiais, de onde advém a dificuldade do judiciário em compreendê-la e trabalhar nessa perspectiva da qualidade do elo social entre os litigantes. Assim, ele elabora que o conflito parece estar associado à ausência de dádiva, percebida pelas partes como um insulto, isto é, falta de reconhecimento ou atos de desconsideração.

Um dos exemplos trazidos à baila é a decisão de alguns juizados de que maridos que agridem suas esposas devem, como pena pela agressão cometida, pagar cestas básicas ao invés de imputar ao marido a pena de prestação de serviços à comunidade, o 
que seria percebida pelo autor como uma punição. Além disso, essa forma de pena - de pagamento de cestas básicas - seria vista como maneira indireta de punir a vítima, pois não só se estaria tirando recursos significativos da unidade doméstica onde ela vive, mas também tal pena não teria o caráter pedagógico que deveria ter, não contemplando, portanto, "demandas de reparação ou de reconhecimento substantivo dos direitos da vítima”. Situação de indignação semelhante ocorre quando o juiz converte a pena de prestação de serviços à comunidade dos adolescentes em pagamento de cestas básicas.

Segundo as técnicas que entrevistei, quando isso ocorre, os adolescentes não compreenderiam como reparo de danos que causaram a sociedade e não sentiriam o peso de uma responsabilização, especialmente porque não é incomum que os pais dos adolescentes paguem essas cestas e, por isso, as profissionais fazem o trabalho de "conscientizar os pais" de que o autor do ato infracional foram seus filhos e que, por isso, eles é que devem pagar pelo que fizeram. Nesse caso, quando há conversão da medida de PSC em pagamentos de cestas básicas, as técnicas orientam a família do adolescente que já trabalha a fazer com que ele mesmo pague, para que "saia do seu bolso". Ainda assim, essa conversão de medida não parece ser bem vista pelas profissionais e, parece-me, relaciona-se com um enfraquecimento do caráter pedagógico que se espera da medida e com a importância da noção de responsabilização, de que tanto me falaram as minhas interlocutoras. Vale assinalar que, nos moldes entendidos por essa cultura ocidental moderna, a responsabilidade é algo atribuído de forma individual, isto é, se foi o adolescente que cometeu o ato é a ele que deve ser atribuída a responsabilização e a reparação do dano e a mais ninguém.

Assim como visto com Berger, a mudança de valores que Taylor (1997) traça coincide com a época do que o primeiro autor chamou de "burguesia triunfante". Assim, o autor entende que a valorização da vida comercial, nos séculos XVII e XVIII, foi se sobrepondo àquela que enfatizava a glória conquistada, dentro de uma perspectiva da honra aristocrática. Esta última perspectiva, que sublinhava as virtudes da vida do cidadão, a busca de fama e renome, e atribuía lugar central às virtudes guerreiras, foi perdendo espaço para a perspectiva burguesa que sublinhava os bens de produção, uma vida organizada e paz, isto é, as atividades da vida cotidiana (TAYLOR, 1997, p. 370). Assim, o "homem mito" foi cedendo espaço a uma narrativa do homem cotidiano. A dignidade aparece envolvida na noção moderna da importância da vida cotidiana, de sentimento de valor pessoal, no sentido de merecer respeito. Taylor cita um exemplo do que pode estar na base de um sentido de dignidade e cuja ausência pode solapar o 
sentimento de valor pessoal do indivíduo: o chefe da casa, pai de família, detentor de um emprego, provedor de seus dependentes (p. 30).

Nesses dois séculos, o romance moderno também surge e revela mais uma vez essa valorização dos eventos e vidas cotidianos, bem como a objetificação do tempo, que traz consigo a noção de um self desprendido, que tem sua identidade constituída na memória, na narrativa de sua própria história. No final do século XVII, o casamento "por amor" aparece como um exemplo da afirmação da autonomia pessoal, da maior individualização das decisões; há o colapso de uma ordem compartilhada e a ascensão da afirmação da independência individual e privacidade para a família, a relação pessoal íntima ganha importância e as casas ganham espaços privativos. O lugar dos sentimentos na vida e sociedade também fica mais importante. A partir do século XVIII, os sentimentos de afeição entre pais e filhos e os sentimentos de amor entre cônjuges passam a ser mais valorizados e cultivados.

Hoje, como também identificado por Schuch (2005), o argumento de falta de amor nas famílias parece corrente para justificar o comportamento dos adolescentes que cometem atos infracionais. Como me disse Marcelo, pedagogo da UAMA que visitei, há constante "ausência da família nuclear na vida dos meninos" e o fato de existirem várias "conjunturas de família". No primeiro atendimento, meninos e famílias não sabem das MSE, por vezes a mãe desconhece inclusive o ato que o filho cometeu. Ele vê as principais causas para os adolescentes cometerem os atos como sendo a falta de afetividade no seio familiar e a desestruturação das famílias.

Taylor (1997) busca fazer uma análise do que está na base da dignidade, refletindo acerca do que torna a vida significativa ou satisfatória. Um dos aspectos da moralidade moderna, que a torna diferente das precedentes, é a ideia de que todos os seres humanos merecem respeito, o que parece ser uma moral universal. O que há de particularmente ocidental nessa proposição é que essa noção do respeito aparece em forma de direitos, sendo essencial aos sistemas legais. O respeito se ramifica nas noções de evitação do sofrimento e do bem estar, que, para o autor, teriam fontes religiosas. $\mathrm{O}$ respeito, em sua acepção moderna, dá grande importância à liberdade, ao autocontrole e à evitação do sofrimento, concebendo a vida familiar e a atividade produtiva como centrais para o nosso bem estar.

Cabe lembrar o argumento de Berger, de que seria a vida privada o lócus principal da definição da identidade na vida moderna, uma vez que não a vinculamos mais tanto aos papéis institucionais. Seria na vida particular, em família, nas suas casas, 
que se poderia descobrir o verdadeiro eu, a identidade, o self. Vale retomar também o que nos disse Elias (1990): aos poucos se começou a conceber uma noção de privacidade que se traduziu, inclusive, na estrutura das casas, hoje compostas por mais espaços privativos do que antes.

De acordo com Taylor, houve um aumento da sensibilidade na modernidade com relação à dor e ao sofrimento, que gerou a prerrogativa importante de se buscar evitá-los. Houve uma mudança na sensibilidade com relação a sentimentos que antes eram considerados banais, como o de pai pra filho e entre cônjuges, que começaram a ser vistos como aspectos importantes para uma vida valiosa e provida de sentido. A sensibilidade em relação à natureza também se aguçou, gerando, inclusive, um conflito com a percepção instrumentalista dela.

Nos termos de Taylor, a vida que se vale a pena viver seria uma vida produtiva e em família, deixando entrever, portanto, a importância do trabalho na vida moderna, como um dos fatores que faz a vida valer a pena, que traz dignidade. Mais uma vez, entende-se o trabalho como algo capaz de prover a vida digna e, inclusive, garantir a sustentabilidade da vida em família, como visto em Taylor.

Essa nova moralidade, moderna, assentada nos valores do trabalho e da vida em família é evidente também nos discursos das profissionais e também dos responsáveis legais. Lembro-me de um atendimento que presenciei em que a mãe do adolescente estava extremamente angustiada e com pressa para encontrar estágio para o filho. Também na oficina de pais que presenciei, um grande tópico de conversa foi justamente a inserção dos filhos em atividade profissional. Uma delas, inclusive, dizia que o filho queria mudar mesmo, mas que sem ter uma ocupação isso seria difícil. Essa preocupação tem marcado tanto a formulação da política do sistema socioeducativo quanto dos profissionais e responsáveis legais que a vivenciam na ponta. No que tange a essa questão, Foucault nos ensina que, qualquer que seja o modelo utilizado, desde os mais repressivos até os ditos mais "emancipatórios" se utilizam dos valores do trabalho e também da família.

Foucault (1993) analisa o caso da prisão sueca chamada Kemela, um grande edifício penal construído com base no ideal que seria o Panóptico de Bentham, realizando o "sonho encantado da penalidade clássica" que, poucos anos após sua abertura, sofreu com uma fuga de prisioneiros, pessoas que recomeçaram sua vida de delinquente após escaparem da prisão. Esse fato demonstrou o fracasso da prisão tanto em termos de detenção de indivíduos quanto de sua correção, haja vista que uma vez 
livres eles reincidiram. Após esse fato, os suecos tentaram definir um programa alternativo a essas prisões clássicas, o que ocorreu também em outros lugares na Europa.

Esse programa alternativo consistia em estabelecimentos pequenos, para 40 a 60 pessoas, onde os indivíduos tinham obrigação de trabalhar, mas não em trabalhos "bestas, estúpidos, desinteressantes, embrutecedores, humilhantes e não pagos, como ocorre em prisões de tipo clássico, mas em trabalhos úteis, remunerados e que possibilitariam a reinserção dessas pessoas na realidade econômica do país".

Eram estabelecimentos que buscavam a permitir o máximo de contato entre os indivíduos e o mundo exterior, especialmente com a família e o seu meio habitual, ao invés de buscar romper esses vínculos, como no caso das prisões tradicionais. Nesses locais, o próprio programa penitenciário é discutido entre administração e conselho de presos que participam da elaboração do regime penal e eventualmente também de forma individual. As permissões de saída são multiplicadas, não apenas como recompensa para boa conduta, mas como meio de reinserção. O trabalho, afinal, é a resposta essencial, fundamental, à infração.

Empregam-se outros meios nos estabelecimentos "alternativos", mas é sempre o trabalho como resposta principal à infração que se encontra tanto nos estabelecimentos alternativos à prisão quanto nas prisões de tipo "clássico". Nesses estabelecimentos alternativos à prisão, vê-se também funcionar o princípio que Foucault chama de "refamilialisation" [como no original em francês], que implica na ideia da família como instrumento essencial de prevenção e correção da criminalidade.

Desde o século XIX, considerou-se que a família era um dos agentes fundamentais da legalidade, da vida legal ou do retorno à vida legal. Essa mesma ideia existe hoje, colocada em prática por outros meios, no que ele chama de "estabelecimentos alternativos à prisão". Sobre os estabelecimentos contemporâneos, ele diz ainda, que se busca fazer os detentos participaram eles mesmos da elaboração do programa penal. Foucault entende esse prática como a busca por fazer o indivíduo punido, seja individualmente ou coletivamente, por meio dos conselhos de detentos, por exemplo, participar dos mecanismos de sua punição. O ideal seria que o indivíduo aceite ele mesmo o procedimento de punição que a ele é aplicado. Se lhe é dada uma parte de decisão dessa definição da pena, dessa administração da pena que ele deve sofrer é para que ele a aceite, para que ele próprio a faça funcionar, é preciso que ele se torne o gestor de sua própria punição (p. 10). Talvez, creio, esse intuito também esteja 
presente quando os profissionais frisam a necessidade de que os adolescentes vejam "sentido" nas medidas socioeducativas e interiorizem uma noção de "responsabilização" pelo ato cometido.

Esse é igualmente um princípio antigo, argumenta Foucault, já existente no século XIX, em que se cria que um indivíduo começava a "se melhorar" quando ele era capaz de aceitar sua própria punição, quando ele era capaz de se dar conta de sua própria culpa. A autopunição como princípio da correção, a família como agente da correção e o trabalho como instrumento essencial da penalidade: esses três grandes mecanismos que caracterizaram o funcionamento da prisão ao longo do século XIX podem ser vistos ainda hoje, dentro desses estabelecimentos ditos alternativos à prisão. De qualquer modo, são as velhas funções carcerárias que se tenta agora fazer funcionar a partir de estabelecimento que não se parecem com prisões (p. 11).

De certa forma, podemos ver isso também na discussão sobre as medidas socioeducativas em meio aberto. Há a expectativa das profissionais a todo momento de que os adolescentes se sintam responsáveis pelos seus atos e entendam que quebram regras da sociedade, devendo, por isso, responder a tal ato. Esse seria o primeiro passo para que a medida socioeducativa "faça sentido" para os adolescentes. Como me contaram, é comum que o adolescente que deve cumprir medida de prestação de serviços à comunidade se revolte por "ter que trabalhar de graça". Houve o caso de um menino que inclusive questionou: "vou trabalhar sem ganhar nada? Mas não sou escravo!". Essa reação foi interpretada pelas técnicas como uma incompreensão do verdadeiro sentido da medida socioeducativa que é, entre outros, o de reparar o dano à sociedade, repor algo que se tirou dela por meio de seu trabalho e entender que houve a quebra de uma regra de convívio em sociedade. Conforme me disseram, no momento em que isso é compreendido pelo adolescente, ele passa a cumprir a medida e é, então, a partir dessa significação da medida que ele pode efetuar o que a supervisora Regina chamou de uma "mudança sólida" de vida. À família fica o comprometimento de auxiliar o adolescente no processo de sua responsabilização, que envolve não só estimulá-lo a cumprir a medida e impor-lhe limites, mas também exigir dele tarefas domésticas, por exemplo, e que ele cumpra com seu papel de estudante. A política preconiza ainda que adolescentes e famílias participem ativamente da construção de um plano individual de atendimento, o PIA, para que metas sejam construídas para a vida dos adolescentes, sobre as quais eles será cobrado pelo profissional que o acompanha na Unidade e pelo juiz. 
Um ponto muito pertinente discutido por Foucault e caro à análise que desenvolvo no âmbito da dissertação é que as funções carcerárias de ressocialização pelo trabalho, pela família e pela auto-culpabilização não estão mais localizadas somente no local fechado da prisão, mas, por meio desses estabelecimentos relativamente "abertos", tenta-se difundir essas velhas funções no corpo social como um todo.

Mas existem outras formas de punição que não passam nem pelas prisões clássicas nem pelas alternativas, que são as supressões de direitos e a imposição de um tipo de trabalho ao indivíduo em meio aberto. Mesmo assim, Foucault vê nesses novos métodos que se usa para punir os indivíduos sem os colocar dentro de prisões também como uma forma de reviver as mesmas funções carcerárias das quais ele falava acima. Impor uma dívida a um indivíduo, suprimir algumas liberdades ou fixá-lo a uma obrigação de trabalho, de produção ou uma obrigação de vida em família são sobretudo também formas de difundir fora da prisão as funções de vigilância, que vão se exercer não mais sobre o indivíduo preso numa cela, mas que vão se propagar sobre o indivíduo aparentemente livre. Um indivíduo em liberdade condicional, por exemplo, é vigiado em sua vida cotidiana.

O sistema alternativo às formas antigas de detenção, alerta-nos Foucault, também têm por função difundirem formas de poder próprias ao contexto da prisão. Assim, para ele, as funções de controle, vigilância e ressocialização que se esperava estarem garantidas pela instituição-prisão é agora buscada por outros mecanismos. $\mathrm{O}$ autor não vê, portanto, alteração do espírito do sistema de encarceramento, apenas diz que o que a prisão tentou garantir de uma maneira brutal é agora tentado de forma mais flexível, mais livre, o que não quer dizer, como ele alerta, que trata-se de um modelo pior que a prisão, que fique claro. Trata-se, como ele diz, de uma variação sobre um mesma tema. Alguém que cometa uma ilegalidade ou uma infração terá seu corpo apreendido, será posto sob vigilância constante, terá seu corpo trabalhado e a ele serão prescritos esquemas de comportamento, ele estará submetido a instâncias de controle e de julgamento, por exemplo, tal como se tinha nos procedimentos punitivos do século XIX.

Assim, alguns princípios identificados por Foucault também são, embora com roupagens diferentes, usados no contexto dos adolescentes autores de atos infracionais. Seguindo-se o passo-a-passo do processo que leva à decisão do juiz por uma medida, tem-se a apreensão do jovem, por exemplo, e a sua colocação em uma instituição de 
internação provisória até que ocorra o momento da audiência, como já explicitado no capítulo 2. Esse momento de internação provisória é vivido com muita dor pelos responsáveis legais dos adolescentes e foi mencionado como grande humilhação, em especial pelas mulheres, mães ou avós dos jovens, que são revistadas de forma extremamente invasiva para poderem visitar os filhos. Além disso, alguns pais citaram o tratamento ruim que recebem nessas instituições e como são vistos de forma negativa pelos agentes que trabalham nesses locais que os olham como se a culpa fosse deles, como se eles não tivessem exercido bem o seu papel como pais e mães, o que os angustia profundamente. Algumas mães ressaltaram: "aquele lugar não é lugar pra gente ficar, pra ser humano, é lugar pra bicho", outra disse "eu nunca imaginei que eu ia ter que pôr os meus pés num lugar como aquele!”.

Sentenciados nas medidas de liberdade assistida, os jovens são então acompanhados em sua frequência escolar, atividades profissionais e devem ser vigiados para não estarem fora de casa desacompanhados de seus responsáveis após às 22 horas. Um dos primeiros tópicos dos atendimentos chamados de acolhimentos, primeiro contato entre o profissional e adolescente em medida, é o que visa a coletar o discurso do jovem sobre o ocorrido que o levou à apreensão pela polícia.

No caso do primeiro atendimento que observei, a psicóloga Denise, quem prestava o atendimento, perguntou ao "menino" se ele havia experimentado e se usava drogas, ao que ele respondeu que não. Apesar de não "acreditar" na resposta obtida, a profissional me contou que preferiu "não forçar" o adolescente a falar, especialmente porque se tratava de seu primeiro encontro e porque a mãe dele estava presente na sala, o que certamente devia estar o inibindo. Além disso, ela citou a importância de se ter cuidado nesse primeiro encontro para não afastar o adolescente da unidade, sugerindo que uma abordagem mais incisiva seria um elemento que poderia fazer com que o adolescente não retornasse ao local para dar continuidade ao seu "acompanhamento". Essa forma de abordagem foi também o que presenciei em um outro "atendimento", também um "acolhimento" de um outro adolescente de quatorze anos. Nesse caso, o adolescente não quis relatar o "ocorrido" que levou à sua apreensão e a profissional, Clarice neste caso, respeitou sua decisão, afirmando "se você não quer falar sobre isso, tudo bem". Como mencionado, perguntar ao adolescente "o que que aconteceu?" é dar a oportunidade a ele de ele "contar a sua versão da história", haja vista que os fatos que o levaram a "pegar uma medida" já são, em realidade, conhecidos pelos profissionais, uma vez que eles estão descritos nos autos dos processos dos adolescentes. 
A ideia de que os adolescentes precisam "assumir a culpa pelo que fizeram" e se sentirem "verdadeiramente responsáveis" para de fato "aproveitarem as medidas socioeducativas" e o tempo na UAMA, podem se relacionar ao que Kant de Lima (1989) chamou de tradição inquisitorial. Ao contrastar o sistema jurídico brasileiro, da civil law tradition, com o sistema jurídico americano, da commom law tradition, Kant de Lima opõe também, nessa ordem, as concepções hierárquicas às igualitárias, individualistas e holistas, presentes nesses sistemas. Além disso, ele destaca as diferenças entre sistemas processuais com ênfase inquisitorial, do tipo brasileiro, a sistemas processuais com ênfase acusatorial, predominante no contexto americano.

Falando da ambiguidade do sistema processual penal brasileiro, que é autodenominado misto e ora aciona princípios acusatórios e noutra, princípios inquisitórias, Kant de Lima trabalha para demonstrar como as práticas da polícia são informadas por representações hierarquizadas e holistas da sociedade, presentes na cultura jurídica e em nosso pensamento social. No sistema acusatório, a preocupação é sempre com o interesse do indivíduo acusado, ao passo que no sistema inquisitorial, a preocupação se dá em manter uma ordem social hierárquica e, muitas vezes, desigual. Procedimentos orientados inquisitorialmente se baseiam na suspeição sistemática e no sigilo.

Durante a sua pesquisa, Kant de lima observou que tanto a defesa quanto o ministério público estabeleciam correlações entre o status social e econômico do réu e seu estágio de "evolução cultural". A defesa chegava a usar argumentos que classificavam os réus de incivilizados, como pertencentes ao domínio da natureza e, assim, não sabiam o que faziam por serem animais desprovidos de cultura, portanto, incapazes de compreender o comportamento civilizado e as leis. Desta forma, não poderiam ser considerados "responsáveis" por seus atos. O próprio uso da violência física pela polícia parece ter relação com o status social e cultural do acusado. Quando estes são "de status social baixo", a violência física é assumida pela polícia como parte integrante do cotidiano dessas pessoas, o que legitima o uso da violência física contra esses segmentos da população. O caso de prisão especial, que consta no código de processo penal, já parece mais um elemento que nos faz pensar no caráter hierárquico e holista do mesmo em contraste com o princípio constitucional de que são todos iguais perante a lei. Ele atribui a fala de controle autônomo da polícia de seus membros em virtude de uma filosofia hierárquica embutida na cultura jurídica brasileira. Pelo fato de a polícia não ser vista como possuidora de uma "maioridade", ela não teria, 
oficialmente, responsabilidade. A base da identidade policial seria a sua tradição inquisitorial, que se encontra estigmatizada pelo sistema judicial. Os procedimentos de inquérito policial abertos contra as classes mais baixas da população, por sua vez, projetam sobre essa população os mecanismos de estigmatização, que, por sua vez, aceitam os estigmas que lhes são imputados e tentam se diferenciar dos "marginais" pelos mesmos critérios de desigualdade que os estigmatizaram, tudo isso numa ordem jurídica que supostamente é igualitária. "Dizem, então, como que se desculpando de sua posição inferior na sociedade, sempre sob suspeição inquisitorial: Eu sou pobre, mas sou trabalhador".

A justificativa da manutenção de um sistema inquisitorial é a proteção dos fracos e dos oprimidos contra os poderosos. Pois se a acusação fosse pública, como no caso do sistema acusatorial, poderia haver consequências. Ao passo que sendo sigilosa, como no modelo inquisitorial, interroga-se, ao final aqueles contra quem há fortes suspeitas. Esse modelo se entende como "encarregado de proteger a população desvalida da vingança dos fortes pela apuração da verdade, livre da influência do poder econômico". Assim, é a esse segmento mais vulnerável da população que não se deveria aplicar a letra da lei, destinada somente àqueles de "maior discernimento", que "compreendem sua falta e devem, assim, expiá-la: como na inquisitivo canônica, a confissão denota a penitência, a compreensão de que se errou e a vontade de reparar o erro cometido".

Assim como observado por Kant de Lima ao tratar das práticas policiais e dos processos penais, em que ele identificou um misto de princípios holistas e individualistas, hierárquicos e igualitários, identifiquei também um híbrido nas práticas dos técnicos e contrastes entre o que deveria ser entendido como a execução de uma medida socioeducativa, conforme pensado pelos profissionais, responsáveis legais e por um ex-socioeducando.

Segundo a pedagoga Isadora, "os meninos quando começam o atendimento na UAMA parecem agarrados na barra da saia da mãe e já no final já estão mais sozinhos”. Durante os atendimentos, os profissionais explicam aos jovens como fazer para tirar a documentação e passam "tarefas" a eles, como a de se inscreverem no CIEE, isso, como me contou, resgata a sua autoestima e faz parte de um entendimento de que o adolescente tem que aprender a fazer certas coisas sozinho para continuar com plano de vida, então veem-se mudanças no que se refere à responsabilidade e independência dos jovens. Na visão da pedagoga Isadora, a responsabilização sobre o ato infracional, algo tão citado pelos técnicos, inclui uma "reflexão sobre o ato", e um sentido mais geral, 
ligado, por exemplo, ao percurso dos adolescentes para "tirarem os seus documentos". A reflexão, contudo, tem que ser indireta, pois confrontar os jovens não dá muito certo, e o adolescente não gosta que batam de frente com ele. Durante o cumprimento da PSC, lembra Isadora, como o profissional que guia os adolescentes no local do cumprimento da medida passa quatro horas direto com eles, a socioeducação é mais próxima. $\mathrm{Na}$ PSC, como tem horário de entrar e sair, a "responsabilização" é maior, diz ela.

Assim, identifico que os argumentos que justificam a maior responsabilização e comprometimento com a PSC variam: uns acessam o seu lado mais disciplinador, referente ao horário, como ocorre na escola, e outros já acessam a noção de uma reflexão da própria vida que se relaciona com a sentimento de ser "útil", de ver resultado de seu trabalho, de aumento da autoestima e vontade de trabalhar "por si próprio", de "cuidar de si", especialmente no caso do zoológico, como citado pela supervisora Regina.

No entendimento de Marcelo, pedagogo, o desenvolvimento dos socioeducandos, buscado pelos profissionais, precisa fazer sentido para eles. Para vários já fez sentido e eles passaram a estudar e a trabalhar. Marcelo frisou que é o jovem que tem que sentir estar pagando pelo que fez.

O estudo e o trabalho, como sugerido acima, além de serem marcos objetivos da política do sistema socioeducativo e condições de uma vida digna e satisfatória, de acordo com marcos morais da modernidade ocidental, também são categorias constantemente, como visto em Foucault, enfatizadas em contextos de "reabilitação" dos sujeitos, como ocorre no âmbito da UAMA. Para além dessas razões, devemos lembrar ainda que frequentar a escola e estar no trabalho também significa estar fora da rua, o que é visto como absolutamente essencial por pais e profissionais da UAMA no processo de mudança de conduta dos adolescentes e alteração de trajetória de vida.

Como nos falou DaMatta (1997), já citado na introdução deste trabalho, a rua no Brasil não é apenas um espaço geográfico, mas uma entidade moral que se opõe à casa. Se à rua são atribuídos imprevistos, malandragem, universo hobbesiano, castigo, governo, marginais e falta de orientação moral; à casa, por oposição, é atribuída a calma, o controle, o parentesco, o sangue, a hierarquia, o respeito dos filhos com os pais, a intimidade e uma menor distância social.

Entretanto, há de se problematizar o significado de rua e de casa para os agentes públicos envolvidos com as medidas socioeducativas (juiz e educador social, por exemplo) e o significado de casa e de rua para os jovens que estão cumprindo as 
medidas. Por vezes, os jovens parecem inverter o significado mais geral da rua ou experimentá-la a partir de um ponto de vista tão específico que parecem até positivá-la e a rua, sob essa perspectiva, parece, inclusive, moldada por características de casa.

Um aspecto interessante que me foi dito pela psicóloga Clarice diz respeito à mudança do significado da rua a partir de certa idade. Ela identifica que a rua se torna "um problema" aos olhos dos profissionais e dos pais a partir da adolescência, pois, se quando se é criança a rua é um espaço de brincadeiras com outras crianças, lugar onde se joga bola e solta pipa, por exemplo, quando se é adolescente ele vira local de encontro para usar drogas e, mais adiante, do envolvimento com o tráfico e outros tipos de atos infracionais.

Martínez-Moreno (2013) identifica a casa, para seus interlocutores jovens na Colômbia, como um local do "medo" e do "tédio". Por outro lado, a rua aparece como espaço de uma sociabilidade entre amigos, local de prazer, uso de drogas, da vida indisciplinada e da liberdade. Para os jovens com quem trabalhou em sua dissertação a boa vida ocorre na rua, sua vida privada acontecia no âmbito público. Isso porque eles não se sentem ouvidos pela família em casa e muitas vezes são discriminados também pela própria família no âmbito da casa (p. 96). Os agentes públicos com quem Martínez-Moreno trabalhou enfatizavam a importância das regras de conduta primeiro em casa para disciplinar e melhorar o relacionamento intrafamiliar.

Assim, também uma das primeiras preocupações esboçadas pelos técnicos e responsáveis legais é a de controlar os seus filhos para que respeitem a sua autoridade dentro de casa e para que se comportem e sejam "menos rueiros". A autoridade dos pais sobre as saídas dos filhos, aliás, parece um tópico delicado. Este é frequentemente ressaltado pelas profissionais da UAMA como uma de suas responsabilidades enquanto pais e enquanto elemento importante da parceria adolescente-família-Estado. Dessa forma, os profissionais sempre indagam aos adolescentes se eles passam muito tempo na rua e o que fazem quando estão nela e, aos pais, se eles sabem para onde vão os filhos quando vão para a rua.

Os pais e mães se preocupam muito com o tempo em que os filhos passam na rua, haja vista que ela, como dito acima, é identificada como a morada dos maus elementos, capaz de influenciar o comportamento dos filhos e acessada diversas vezes pelos responsáveis dos adolescentes como o que de fato os fez cometer o ato infracional. Reproduzo abaixo algumas falas de mães que estiveram presentes na oficina de pais de que participei na UAMA: 
Mãe 1 - ele [meu filho] é muito carinhoso, passou da porta pra fora ele vai com os colegas

Mãe 2 - se você olhar pra ele você não diz que ele é capaz de ter feito isso, não sei de onde esses meninos tiram ideia de fazer essas coisas.

Mãe 3 - com emprego, ele mudaria, mas como ele tem tempo, vai pra rua.

Fonseca (1994) lança luz sobre a grande preocupação, entre grupos populares, com o fato de os filhos "ficarem na rua" que pode também ser pensada para o caso que estudo. A autora acentua a diferença que existe do conceito de adolescência como fase de vida entre classes populares e classes médias contemporâneas. Para essas últimas, a adolescência seria considerada um período de emoções tumultuadas, idade de difícil da vida onde a criança seria autorizada a fazes "algumas mancadas", mas que seria algo transitório, podendo as falhas serem recuperadas depois. Para esses grupos, problemas com os estudos seriam advindos, por exemplo, de uma imaturidade própria da fase, havendo a possiblidade de ele se diplomar ao concluir algum supletivo ou ainda adquirindo maturidade por meio de viagens ou intercâmbios internacionais. Entretanto, pontua a autora, os erros da juventude para os grupos populares são quase irremediáveis. "O perigo que ameaça as filhas diz respeito à moralidade sexual. Temese que a menina engravide e seja abandonada pelo companheiro". No caso dos meninos, teme-se que ele "comece a fumar (maconha) e se junte aos guris da esquina", tornandose um "marginal". Assim, parentes e vizinhos lamentam-se, crendo que para o futuro do rapaz resta apenas a morte ou a cadeia.

Tais preocupações também surgiram durante o meu campo. Algumas profissionais criticam o fato de meninas irem morar cedo demais com companheiros e não se preocuparem em buscarem outros caminhos de vida e citam o uso de drogas e os encontros com outros adolescentes na rua, especialmente no caso dos meninos, como um fato crucial para pensar seu envolvimento com atos infracionais como furto, roubo e tráfico. Fonseca menciona ainda que os maiores perigos que pairam sobre as crianças vêm justamente da "rua", enquanto espaço moral, pois nela, "terra de ninguém" e local de "violência potencial" (tanto de bandidos quanto de policiais), habitam as "más companhias", que podem exercer uma influência moral contrária à orientação dada pelos pais.

Tendo em vista essas preocupações e o rumo incorrigível que os jovens - de classes populares - podem tomar nessa fase da vida, Fonseca fala de uma "obsessão dos pais com a vigilância que esperam do colégio". Essa vigilância, tal como pude constatar 
nas oficinas com pais de que participei, também é esperada pelos responsáveis legais dos adolescentes em medida da parte dos profissionais da UAMA. Isto é, os pais esperam das técnicas que sejam mais duras, que deem "puxões de orelha" em seus filhos, que exerçam, inclusive, tipos de autoridade que não estão em seu alcance. No caso dos adolescentes em medida, os pais se queixam de não serem ouvidos pelos filhos e terem perdido autoridade. Uma mãe na oficina que assisti inclusive lamentou-se e disse já estar conformada com o destino de seus dois filhos: a Papuda. Ainda sobre a vontade de que seja exercida alguma autoridade sobre seu filho, vale lembrar o discurso do pai exaltado durante a oficina, que comentei acima, que, em tom de cobrança, esbravejava que as atividades da UAMA se desenvolviam de forma "liberal demais" para o seu gosto.

Conforme me contou Marcelo, pedagogo da Unidade, é comum o sumiço dos filhos quando estes vão para a rua e uma dificuldade dos pais em trabalharem limites junto a eles. Na fala da psicóloga Denise, fica claro que a rua é sinônimo de problemas. A profissional me disse que raramente o adolescente que está "em LA" é apreendido apenas por estar na rua após às 22 horas desacompanhado, o que, segundo as regras da medida socioeducativa, já caracteriza um "descumprimento". Contou-me que "normalmente quando ele é apreendido é porque está cometendo um outro ato infracional e não simplesmente porque estava na rua".

A busca das profissionais é em grande parte para que os "meninos" se engajem na escola e em cursos e trabalhos, sendo este último uma tarefa difícil, pois a baixa escolaridade deles não lhes permite obter estágios ou postos de emprego formais, como preconizado pela política. A esse respeito cabe dizer que existem programas de estágio cuja uma parcela das vagas é preferencialmente ocupada por "meninos em medida". No primeiro atendimento que observei, feito pela psicóloga Denise, o jovem estava inserido em um desses programas, o que, segundo a sua mãe, foi a primeira coisa que lhe ocorreu quando soube "do que aconteceu" com seu filho, isto é, do fato que o levou a ser apreendido. Disse ela que assim que soube do "ocorrido", "já correu logo" para pôr o filho no programa de estágio (Jovem Candango). A importância do trabalho foi acessada diversas vezes durante o "atendimento" tanto pela mãe do menino atendido quanto pela profissional que o atendia. Essa importância se relaciona especialmente à necessidade de tirar o menino da rua, pois na rua se faz o que não deve e envolve-se com más amizades, ao passo que no ambiente do trabalho se tem a oportunidade de se pensar em outras coisas e a conhecer outras pessoas, com quem o relacionamento é 
encorajado. Como me disse Gabriel, que é voluntário em uma instituição na condição de orientador dos trabalhos dos adolescentes em medidas socioeducativas, ele incentiva os meninos a procurarem estágios para entrarem em contato com "pessoas que deram certo", para verem "como é bom ter outra vida, pensarem em poder viajar nas férias, ir a bons hospitais, terem seu filhos sem preocupação".

No primeiro atendimento que presenciei, algumas questões acerca do comportamento do adolescente em casa e se ele passava muito tempo na rua foram perguntadas à mãe e ao menino. A profissional Denise indaga a mãe do menino sobre suas saídas. Segundo ela, ele fica muito tempo na rua. A profissional pergunta onde o menino costuma ir e se a mãe sabe onde fica. Ela responde que à noite ele não sai muito para lugar longe, que fica na porta de casa e que sempre avisa para onde vai. Após o atendimento, converso com a mãe do menino. Ela me fala da sua expectativa de que o filho pare de cometer "atos infracionais", o que, segundo ela, já estaria ocorrendo, uma vez que desde a sua primeira apreensão e de sua decisão de se mudar para que o filho não mais se relacionasse com as "más amizades", ela crê que ele não havia mais cometido nenhum outro ato. Essa fala final da mãe do jovem acolhido deixa ainda mais evidente como os espaços geográficos são vistos como entidades morais perigosas, o que justifica, inclusive, a decisão, não incomum, segundo me contaram as profissionais, de a família se mudar de bairro ou de região administrativa para afastar os filhos das companhias e, logo, da trajetória de cometimento de atos infracionais.

Gabriel disse-me que, em virtude do trabalho que desenvolve, tem a oportunidade de conhecer um pouco mais da realidade dos adolescentes: "a maioria não tem pai, não tem uma família estável, apanha em casa", contou-me. Disse-me que uma vez deu carona a uma garota que cumpria medida na instituição em que ele trabalha como voluntário. Ela chamava-o de "professor".

Gabriel contou-me que no trajeto, ela lhe fez uma pergunta curiosa: "professor, você consegue dormir na sua casa?". Ao que ele respondeu: "claro que durmo, como assim?”. E a menina seguiu: “é que na minha casa não dá pra dormir, tem frevo todo dia". Pedro perguntou “o que é frevo?" e ela disse "festa, agitação, bagunça". Então Gabriel se virou para mim e disse: “a única influência que eles têm é assim!”. Gabriel me falava muito dos "bons exemplos" como essenciais para que os adolescentes desenvolvessem boas condutas, o que, segundo ele, faltaria a eles no espaço de casa, na escola e, especialmente, nas ruas dos bairros onde moram. "Esse lugar onde eles moram", falou-me, "não é lugar para se soltar um adolescente não". Pela fala de 
Gabriel, depreendemos que, ao contrário do que aparece em DaMatta, também a casa não parece um local moralmente ideal para o desenvolvimento dos adolescentes, uma vez que os bairros onde geralmente os adolescentes vivem não oferecem essa condição.

Gabriel ressalta que ele "acredita mesmo é na educação, que enquanto não tirar esses meninos da rua, a situação não será resolvida". Ele cita uma escola em Luziânia, que teria passado a ser coordenada por militares - ele falou também em polícia militar, mas não soube precisar e não consegui acesso a esta informação - o que foi algo bom, segundo ele. Lá as crianças ficam de castigo quando fazem algo que não deviam, e pagam, por exemplo, pintando a escola, de modo que a instituição está sempre "arrumadinha, todos chegam no horário, e é um lugar que dá gosto de frequentar", ao contrário da maior parte das escolas da rede pública que, como ele havia pontuado antes, são "bagunçadas, sujas, têm muito professores faltantes". Ele comenta da dificuldade de os meninos recebidos na hora de aceitarem disciplina e de sua grande dificuldade de seguir regras. Falam que essa dificuldade é uma dificuldade dos adolescentes, mas ele identifica que entre os meninos que cumprem medidas é muito pior. Na visão esboçada por Gabriel, parece que a via mais disciplinadora de conduta com relação aos adolescentes e, em especial, aos adolescentes em medidas socioeducativas, seria mais eficaz.

Apesar do reiterado argumento da escola como espaço que deve ser frequentado pelos jovens, há de se considerar dificuldades de acesso em termos não só da disponibilidade de vagas em locais acessíveis para os jovens, mas também de ordem material. Como presenciei, há casos em que a escassez de recursos familiares é acentuada. Fonseca (1994) também aponta para as dificuldades de ordem material que acabam por afastar os adolescentes das classes populares do ambiente escolar e comenta uma visão que os pais têm sobre os estudos: veem com grande prestígio o ensino escolar. Entretanto, conforme argumenta a autora, a preparação para a vida adulta entre essa população é fortemente marcada por outras estratégias, a exemplo da circulação das crianças e adolescentes para outras casas - seja de vizinhos ou parentes -, onde elas aprendem algumas habilidades ou ainda por meio do trabalho junto a adultos, na condição de aprendizes, também como estratégia para que aprendam profissões que exercerão no futuro, o que também apareceu no contexto da UAMA, com o caso de meninos que vão trabalhar com os seus pais durante o dia, o que, por sua vez, conectase à necessidade de trabalho e aprendizado de uma profissão e à própria evitação da rua. 
Apesar de o texto de Fonseca ter sido escrito há mais de uma década, a realidade de abandono escolar que ela cita também ocorre hoje no caso dos adolescentes que frequentam a UAMA. As minhas interlocutoras também mencionam a grande desistência de continuar o ensino escolar da parte dos adolescentes atendidos e que, de forma coincidente com o que Fonseca expõe em seu texto, dá-se por volta dos 13 e 14 anos. Conforme me disse Regina, a segunda supervisora da Unidade com quem conversei: "deveria se fazer um estudo para ver por que é justo nessas séries que os adolescentes desistem". Fonseca lança uma luz sobre essa questão quando alude a ser justamente nessa fase, com a qual coincidem fracassos escolares e questionamentos acerca da utilidade do que se está aprendendo para o preparo para a vida adulta, haja vista que o caminho escolar não é único enxergado por essas pessoas. A própria fala dos profissionais que aludem à fase da adolescência como um momento de auto-afirmação e fase crítica do desenvolvimento das pessoas, em que se elas estão sujeitas a influências diversas, pode ajudar-nos a levantar hipóteses sobre essa idade coincidente de abandono. Como disseram Gabriel e Marcelo: “eles não sabem dizer não e dizer sim”, “qualquer um os leva na conversa". Entretanto, há de se alertar que a exacerbação dessa condição de ser humano que "não sabe o que está fazendo" se, por um lado, pode justificar um tratamento legal diferenciado, por outro, pode prejudicar os próprios princípios de responsabilização e autonomia que a política do sistema socioeducativo visa a construir. 


\section{CONCLUSÃO}

No presente trabalho, procurei mostrar como distintos atores que estão envolvidos com o chamado sistema socioeducativo e, em especial, com as medidas socioeducativas em meio aberto em uma UAMA do DF, pensam os métodos de se lidar com as situações pessoais e familiares de adolescentes ditos "autores de atos infracionais". Um dos focos dessa dissertação foi discutir estratégias para a transformação de condutas individuais desses "sujeitos de direitos", tendo como mote tanto a discussão de uma ética religiosa que partiu do discurso do ex-socioeducando Rafael, quanto a própria noção de técnicas de administração de populações em contextos ocidentais modernos, enfatizando a diversidade de discursos que pendem, de um lado, para visões mais disciplinadoras, repressivas e tutelares e, de outro, para noções de autonomia e emancipação dos sujeitos, ancoradas, por vezes, em perspectivas neoliberais no que tange às condutas, sendo estas entendidas como próprias do indivíduo, enquanto ideia-valor central da modernidade ocidental, por contraste a uma ideologia holista e hierárquica.

Como visto no capítulo 1, a partir da implementação do ECA no Brasil, passouse a considerar crianças e adolescentes no Brasil como sujeitos de direitos e trouxeramse garantias de tratamento, ancoradas na noção de infância universal, diferentes das dos adultos, em especial no caso de adolescentes autores de atos infracionais, tema deste trabalho. Conforme nos lembra Fonseca (2004), a Lei Federal 8.069/1990 - ECA - foi visto por muitos como trazendo diversas vantagens sobre as suas edições anteriores, de 1927 e 1979. Uma delas seria a troca do termo estigmatizado "menor" pelo "mais ameno criança e adolescente", além da substituição de uma política que era tutelar por uma filosofia de "proteção integral à criança". Assim, como pontua, "um evidente desejo de controlar jovens cedeu lugar ao desejo de garantir seus direitos". O ECA foi visto por muitos ativistas, diz, como "marco histórico que mudaria o destino das crianças brasileiras” (FONSECA et al, 2004, p. 103). Como citado na introdução dessa dissertação, Fonseca também retoma a ideia de que a constituição de uma legislação como ECA foi fruto tanto de militância interna, num contexto de "reabertura democrática" como também de pressões internacionais.

Mencionei ainda os instrumentos de ação e algumas ferramentas criadas para a gestão da política do sistema socioeducativo e que têm avançado no sentido de implementação das ações do sistema socioeducativo, conforme o capítulo 1. Mostrei 
ainda o perfil dos adolescentes autores de atos infracionais e dos meninos atendidos na UAMA visitada, no capítulo 2, mencionando a minha entrada em campo e o perfil dos profissionais que conheci.

No capítulo 3, a partir da participação em oficinas conduzidas na UAMA, em que se apresentou um ex-socioeducando, Rafael, discuto a alteração de sua trajetória sobretudo no que se refere à sua conversão religiosa. Tendo em vista a experiência de Rafael, afirmei que esse ator se inscreve no âmbito de uma estratégia considerada moderna clássica, para usar os termos de Côrtes (2007), uma vez que dada sua opção por uma ética religiosa protestante tradicional que, nos termos de Weber, prega uma conduta ascética e sóbria, por meio da condenação de certos usos do dinheiro, vocalizados também por Rafael ao se referir às aquisições e desejos materiais, bem como uma ética do trabalho, que, em termos do protestantismo clássico, dá-se para fins de confirmação do fiel no que tange a ser um eleito por Deus, da qual deriva uma vida regrada e um cotidiano disciplinado. Conectado a essa opção religiosa, Rafael se inscreve na lógica de uma modernidade disciplinar clássica também pelo fato de defender meios repressivos de se lidar com adolescentes autores de atos infracionais.

Por oposição a essa visão tutelar, disciplinar e repressiva, opus uma noção ligada à autonomia e emancipação dos sujeitos, característica de uma estratégia neoliberal de governar que enfatiza as liberdades de escolha, e esboçada pela maioria das profissionais da UAMA. Entretanto, a liberdade de que falei não significa, como argumentei, poder escolher qualquer caminho, mas aqueles dentro de uma miríade de possibilidades, considerados os corretos, ou seja, as boas escolhas. Essas, como vimos, envolvem, sobretudo, a educação formal e o trabalho, seja na forma de um vínculo empregatício ou de um estágio, sendo esses dois quesitos vistos como essenciais ao sujeito moderno ocidental. Sobre o trabalho, em especial, ressalta-se que se trata de um valor na moralidade da modernidade ocidental e se apresenta como portador de sentido do existir nesse contexto. Entretanto, como mostrado, nem sempre a escola e o trabalho são vistos dessa forma pelos jovens atendidos.

De acordo com Gabriel, que acompanha adolescentes em PSC, o fato de a escola não ser atraente diz respeito mais a uma carência material das instituições que normalmente eles frequentam; na visão das técnicas, eles não se sentem motivados e têm dificuldades no aprendizado, algumas vezes por problemas de saúde não diagnosticados, ou acabam perdendo o interesse em virtude da vontade de ficar na rua com amigos ou utilizando o tempo para ganhar algum dinheiro, o que lhes parece mais 
atrativo do que estudar. Como visto em Fonseca (1994), há a hipótese de que a educação formal não tenha o mesmo impacto na vida de pessoas pertencentes a grupos populares frente ao que se passa com pessoas das camadas médias brasileiras, aliado ao fato de os primeiros incorporarem outras formas de socialização para a vida adulta que não apenas aquela proporcionada por ambientes escolares.

Vale citar ainda que, com todos os problemas das instituições escolares, a política exige dos profissionais da UAMA que cobrem dos adolescentes uma frequência à escola e algum tipo de envolvimento com o mundo do trabalho. Apesar dos discursos técnicos de que "as estatísticas dizem que o cometimento de atos infracionais está ligado a um menor nível de escolaridade", percebe-se que a escola e também o trabalho aparecem como formas de disciplinamento do corpo e das condutas, em sentido foucaultiano, assim como a orientação da política parece apontar para uma configuração de um sujeito de direitos livre para fazer escolhas que sejam, preferencialmente, aquelas orientadas pelas profissionais do sistema socioeducativo, de modo que pode-se afirmar que ambas se constituem de técnicas de gerenciamento de populações.

Sobre as técnicas, aliás, para se lidar com essa população específica adolescentes autores de atos infracionais - mencionei ainda o choque de entendimentos e expectativas entre profissionais do sistema, responsáveis legais dos adolescentes e de um ex-socioeducando. Se alguns acentuam o caráter emancipatório e individualista da maneira de conduzir a mudança do adolescente, outros entendem que esta só poderia se dar por uma vida mais repressiva, pensando, por exemplo, o discurso de alguns pais que insistem que o diálogo não é suficiente para efetuar transformações de comportamento e demandam ações mais severas e punitivas da parte das profissionais, além de uma noção mais tutelar do que deve ser a política das medidas socioeducativas para os adolescentes, quando pensamos na noção de Rafael, ex-socioeducando, de que os adolescentes não teriam condições de escolher o bom caminho por si próprios, sendo necessário, em um primeiro momento, permanecerem em instituições de internação, para, após algum tempo, saírem aptos a conduzirem sua própria vida de forma responsável.

Há também a própria tensão entre uma perspectiva que se ancora sobretudo numa noção ocidental moderna que acentua a centralidade do indivíduo, tanto no processo de sua autogestão, autorrealização e autotransformação, muito presente também nas formas ditas liberais de governo, e outra perspectiva que olha para o adolescente como parte de um todo, e que precisa de uma intervenção enquanto parte 
desse todo, sendo ainda não capaz de tomar as rédeas de sua própria vida e tendo a necessidade, inclusive, da intervenção de sujeitos hierarquicamente superiores, na figura do juiz, por exemplo, para "se endireitarem". Percebe-se também perspectivas que estão entre dois polos: um que entende o adolescente enquanto indivíduo e único responsável por sua vida e, logo, por suas escolhas e por sua responsabilização, e outro que entende que por trás do adolescente existiria todo um contexto social mais amplo que justificaria e, por isso, dividiria com ele, a responsabilidade por seus atos.

Sobre essa tensão, parece-me, a política do sistema socioeducativo fica pequena para dar conta de um universo tão complexo quanto este em que estão envolvidos os adolescentes autores de atos infracionais. Tal como entendo, a partir de um posicionamento pessoal, a emancipação dos sujeitos parece uma perspectiva acertada, assim como a noção de uma responsabilização individual, já entendida como uma resposta que a sociedade poderia esperar de um adolescente em conflito com a lei, por oposição a medidas de cunho tutelar e repressivo. Entretanto, não se pode fechar os olhos para uma estrutura maior, que não diz respeito apenas às considerações sobre formas de punir ou de educar esses jovens, mas sim à compreensão de um contexto de desigualdades de vários tipos que marca as suas vidas. Isto é, não se pode cair na ilusão de que a visão neoliberal seja de fato tão libertadora quanto o seu discurso faz parecer. Não apenas porque, como nos mostrou Rose, o nosso próprio conceito de liberdade foi cunhado no âmbito de uma estratégia de governo do Estado, mas porque, especialmente no caso brasileiro, a sociedade que está posta certamente não oferece a mesma amplitude de campo de possibilidades a todas e todos. Isso significa reconhecer que a promessa emancipatória também tem seus limites e carece de uma série de ações para que possa, de fato, oferecer as mesmas chances de autonomia a todos os cidadãos e cidadãs.

A esse respeito, gostaria de trazer à baila um trecho de uma das últimas entrevistas que realizei em campo, com Aline, a única assistente social que estava em atividade na Unidade. Como já exposto no capítulo 2, Aline ressalta que a situação em que os adolescentes estão "não é só por culpa deles e o esforço não deve ser somente deles, todos têm responsabilidade, a sociedade em geral, a família, o adolescente e o Estado". Ressalto ainda um último trecho da entrevista com Aline, em que ela compara a sua deficiência visual com a situação de dificuldades cotidianas enfrentadas pelos adolescentes atendidos na UAMA: 
Me identifico muito com a situação deles, tenho deficiência, a escola não foi adaptada pra mim, como eles, eu sofri com a estigmatização, foi diferente, claro, mas aconteceu. Eu que me viro, foi tudo um esforço pessoal meu, de adaptar meus materiais, de eu me adaptar à sociedade, porque ela não é adaptada a mim, nem para eu aprender, nem para me locomover. É cruel ter que partir só de mim, olha o tamanho da sociedade! Por que eu, só eu, tenho que me adaptar à sociedade? As coisas estão invertidas, os valores estão invertidos! É só olhar as estatísticas, as pessoas que se encontram tanto no sistema socioeducativo quanto no sistema carcerário são normalmente negras, na linha da pobreza, pessoas descriminadas a vida toda. Me sinto excluída da sociedade, como se a sociedade tivesse me rejeitado, e eles também, tudo tem que partir muito deles, a mudança depende muito só deles.

A visão de Aline, portanto, ajuda-nos a enxergar que as escolhas não são simples e não se pode falar em grande expansão do campo de possibilidades desses jovens, quando, por exemplo, eles estão ávidos para fazer algum curso profissionalizante e o único que há disponível é o curso de padeiro. "Não que eu esteja desmerecendo a profissão de padeiro, mas os meninos não querem isso, eles querem outras coisas e quando eles procuram, eles não encontram", fala Aline. Nesse sentido, a construção de um projeto de vida para o adolescente, bem como a tentativa de empoderá-los - e suas famílias também - enquanto sujeitos de direitos ainda esbarram em "problemas estruturais" de uma sociedade desigual e competitiva como a brasileira, em que certos sujeitos, com passado de opressão e negação de direitos, são chamados a uma "responsabilização" e imersos em uma cultura em que as medidas em meio aberto "não valem de nada" e em que o crime é punido pelo sistema penitenciário, o que também está na expectativa dos adolescentes. Mas Aline entende que "ninguém é só algoz ou só vítima, somos todos vítimas e alogozes".

Com o que apresentei neste trabalho, não foi meu intuito discutir, por exemplo, se há carência de capacitações para os profisssionais da ponta trabalharem na perspectiva do ECA, nem afirmar que a visão dos responsáveis dos adolescentes atendidos representa uma sobrevivência de um tempo em que a lei era diferente ou que são um segmento em um estágio menos avançado de uma cultura de direitos que emperra a efetiva prática da condição dos adolescentes enquanto sujeitos de direitos. O que gostaria que ficasse claro, nesse momento final de reflexão, é que apenas a criação de uma lei "avançada" como o ECA não é suficiente para alterar paradigmas vigentes em nossa sociedade e nem a sua macroestrutura, marcada por desigualdades diversas, a exemplo do perfil racial e socioeconômico que historicamente foi alvo das políticas de 
controle social e que hoje é preponderante no sistema socioeducativo (ver capítulo 2) e também nas instituições prisionais brasileiras ${ }^{31}$.

Segundo dados a que se refere o relatório do $\operatorname{IPEA}^{32}$ (Instituto de Pesquisa Econômica Aplicada, junho de 2015) sobre a discussão da redução da maioridade penal, dos 21 milhões de adolescentes que vivem no Brasil (dados PNAD/IBGE de 2012 e do SINASE/2012), menos de meio por cento (0,013\%) cometeu atos contra a vida, isto é, cumpriam, em 2012, medidas socioeducativas de privação de liberdade por atos análogos a homicídio, latrocínio, estupro e lesão corporal. Segundo essas informações, a maior parte dos jovens são vítimas de violência e não os autores dela. Ainda, dados mostram que grande parte dos jovens se encontra desprotegida de políticas públicas e direitos sociais básicos.

A lei, como já nos mostrou DaMatta (1997), é vista pela sociedade brasileira mais ampla como instrumento de punição e de repressão e, conforme observado em algumas situações na UAMA, ainda não o deixou de sê-lo ${ }^{33}$. É emblemática, por exemplo, a vontade dos pais de que os profissionais sejam mais duros com seus filhos, de que esses sejam logo presos ou de que sejam chamados para ouvirem sermões do juiz, numa clara compreensão deste (e também do Estado, por que não?) enquanto um agente repressor e não aquele, como deveria de ser, responsável por garantir a aplicação da lei e, inclusive, os direitos dos sujeitos.

Como visto, o campo do sistema socioeducativo é marcado por disputas e contrastes acerca das técnicas de governo que aparecem nos discursos de atores diversos como mais ou menos eficazes. Assim, é possível compreender os contrastes de opiniões de profissionais, responsáveis legais e demais atores que se relacionam com o sistema socioeducativo e os híbridos que surgem das vivências e práticas da legislação em voga. Na conclusão deste trabalho, sugiro, entretanto, que não se compreenda as dissonâncias identificadas em campo em termos de discursos modernos ou não-modernos ou de duas

\footnotetext{
${ }^{31}$ Sobre a realidade do encarceramento de jovens no Brasil, ver, por exemplo, o Mapa do Encarceramento - Os jovens do Brasil. Disponível em http://juventude.gov.br/articles/participatorio/0009/3230/mapaencarceramento-jovens.pdf, acesso em 21 de junho de 2015. Segundo esse documento, há uma seletividade racial no sistema prisional brasileiro, haja vista que se observa que no período de 2005 a 2012 o encarceramento de negros aumentou mais do que o de brancos. Em 2012, para cada grupo de 100 mil habitantes brancos acima de 18 anos havia 191 brancos encarcerados, enquanto para cada grupo de 100 mil habitantes negros acima de 18 anos havia 292 negros encarcerados, ou seja, proporcionalmente o encarceramento de negros foi 1,5 vez maior do que o de brancos em 2012.

32 http://www.ipea.gov.br/portal/images/stories/PDFs/notatecnica_maioridade_penal, acesso em $21 \mathrm{de}$ junho de 2015.

${ }^{33}$ Reconheço a existência de movimentos recentes que enxergam na lei uma possibilidade de acesso e ampliação a direitos. Entretanto, esse não me pareceu o caso que se apresentou em campo.
} 
etapas distintas da modernidade, uma sólida e outra líquida, como exposto por Côrtes. Isto seria, como entendo, incorrer no erro de imaginar que o que se apresenta diante de nós é uma "modernidade errada ou parcial". Ao invés disso, prefiro imaginar que estamos diante de uma modernidade complexa e com contornos muito particulares ou, como pondera DaMatta (1997), diante de uma realidade em que os sistemas hierárquicos e igualitários estão operando em reflexividade, o que, deve-se ressaltar, não significa que parcelas da população brasileira não estiveram excluídas do projeto modernizador.

Nos termos de DaMatta (1997), o sistema social brasileiro igualaria num plano e hierarquizaria em outro, promovendo uma "complexidade classificatória" (DAMATTA, 1997, p, 200). No Brasil, afirma o autor, as relações sociais formam o núcleo do que chamamos de "moralidade", tendo grande peso no "jogo vivo do sistema" e ocupando "espaços que as leis do Estado e da economia não penetram" (p. 202). O sistema brasileiro, aliás, fundado no "respeito", "honra", "favor" e "consideração" estaria sendo a todo momento ameaçado pelos eixos da economia e da legislação, que se constituem de mecanismos universalizantes (p. 206). Assim, o igualitarismo formal e legal se encontra frágil na prática social e submetido a outras formas de hierarquização social. $\mathrm{O}$ domínio das relações pessoais - área não atingida pelas leis - tem forte componente moral e não legal. Desta forma, conclui o autor, "as relações entre a nossa modernidade - que se faz certamente sob a égide da ideologia igualitária e individualista - e a nossa moralidade (que parece hierarquizante, complementar e 'holística') são complexas e tendem a operar num jogo circular" (DAMATTA, 1997, p. 209).

O ditado brasileiro "aos inimigos a lei, aos amigos, tudo!", como afirma o autor, deixa entrever a diferenciação entre indivíduo e pessoa na sociedade brasileira. De um lado, há a moral rígida e universal das leis ou regras impessoais de feição modernizadora e individualista e, de outro, a moralidade das relações totais impostas por relações sociais e pessoais, que permitem "pular a regra". Nessa perspectiva, aos adversários, como nos remete o ditado citado acima, "basta o tratamento generalizante e impessoal da lei”, aplicada sem distinção, consideração ou atenuantes e, para os amigos, vale tudo, "inclusive a possiblidade de tornar a lei irracional por não se aplicar evidentemente a eles" (p. 225).

O sistema brasileiro seria pensado, pois, por duas bases: no caso das leis gerais e da repressão, seguir-se-ia o código burocrático ou a vertente impessoal e universalizante, igualitária do sistema. Mas na "vida real", seguiríamos o código das 
relações e da moralidade pessoal, tomando a "vertente do jeitinho, da malandragem e da solidariedade como eixo de ação". No primeiro caso, a unidade é o indivíduo e no segundo, a pessoa. A pessoa é a figura que merece o tratamento diferenciado, ao passo que o indivíduo é o sujeito da lei, para quem as regras e a repressão foram feitas.

Tendo essas constatações em vista, não parece incompreensível a direção que os atuais movimentos em favor de medidas mais repressivas contra adolescentes autores de atos infracionais, a exemplo da recente aprovação da PEC 171/93 pela comissão especial da Câmara dos Deputados ${ }^{34}$. O texto da Proposta de Emenda à Constituição prevê a redução de 18 para 16 anos da maioridade penal em casos de crimes hediondos cometidos por adolescentes. A contradição destes movimentos (que preveem outros entendimentos acerca dos atos cometidos por adolescentes) com o que é preconizado pelo ECA - em especial no que se refere ao princípio da imputabilidade penal dos adolescentes e ao de brevidade e excepcionalidade das medidas de privação de liberdade e respeito à condição peculiar de pessoa em desenvolvimento -, ao invés de "sem sentido", reforça os argumentos que aqui expus e a complexidade da sociedade brasileira no que tange à discussão sobre técnicas de governo e expectativas quanto às formas de administração de adolescentes no Brasil que, logo, acabam por desembocar em práticas diversas voltadas a essa população e em ordenamentos jurídicos que parecem de fato contraditórios.

\footnotetext{
${ }^{34}$ Fonte: http://noticias.uol.com.br/cotidiano/ultimas-noticias/2015/06/17/sob-protesto-e-forte-segurancacomissao-aprova-reducao-da-maioridade-penal.htm, acesso em 21 de junho de 2015.
} 


\section{REFERÊNCIAS BIBLIOGRÁFICAS}

AMORIM, Maria Stella de. Conflitos no mercado de bens e serviços. Consumidores e consumidos. Texto apresentado na $26^{\text {a }}$ Reunião Brasileira de Antropologia, realizada em Porto Seguro/BA, de $1^{\mathrm{o}}$ a 4 de junho de 2008. In Anais 26 ${ }^{\mathbf{a}}$ RBA. 2008.

BELOFF, Mary. Los adolescentes y el sistema penal. Elementos para un discusión necessaria en la Argentina actual. Presentación leída en el Seminario para Auxiliares Docentes de Derecho Penal y Procesal Penal de la Facultad de Derecho de la Universidad de Buenos Aires, en el premier semestre del año 2002.

BERGER, Peter. On the Obsolescence of the concept of honor. In Stanley Hauerwas, Alasdair MacIntyre (eds), Revisions: Changing Perspectives in Moral Philosophy, Notre Dame (Indiana), Notre Dame University Press, 1983, p. 172-81 (286 p).

BRASIL. Decreto n. 99.710, de 21 de Novembro de 1990. Promulga a Convenção sobre os Direitos da Criança no Brasil.

BRASIL. Lei federal n. 8069 de Julho de 1990. Dispõe sobre o Estatuto da Criança e do Adolescente e dá outras providências.

BRASIL. Presidência da República. Secretaria de Direitos Humanos (SDH). Levantamento Anual dos/as Adolescentes em Conflito com a Lei - 2012. Brasília: Secretaria de Direitos Humanos da Presidência da República, 2013.

Disponível em http://www.sdh.gov.br/assuntos/criancas-eadolescentes/pdf/levantamento-sinase-2012. Acesso em 30 de abril de 2015.

BRASIL. Sistema nacional de atendimento socioeducativo - SINASE. Conselho Nacional dos Direitos da Criança e do Adolescente. CONANDA. Brasília, 2006.

BRASIL. Secretaria Nacional de Assistência Social. Tipificação Nacional dos Serviços Socioassistenciais. Brasília, 2009. 
BRASIL. Lei $\mathbf{n}^{\mathbf{0}}$ 12.594, de 18 de janeiro de 2012. Institui o Sistema Nacional de Atendimento Socioeducativo (Sinase).

BURCHELL, Graham; GORDON, Colin; MILLER, Peter. The Foucault effect: studies in Governmentality. Chicago: The University of Chicago Press, 1991.

CARDOSO DE OLIVEIRA, Luís Roberto. Honra, Dignidade e Reciprocidade. In Série Antropologia. Brasília: UnB, 2004.

CÔRTES, Mariana. O bandido que virou pregador. São Paulo: Hucitec, 2007.

DAMATTA, Roberto. A casa \& a rua. Espaço, cidadania, mulher e morte no brasil. $5^{\mathrm{a}}$ edição. Rio de Janeiro: Rocco, 1997.

DAMATTA, Roberto. Carnaval, Malandros e Heróis: para uma sociologia do dilema brasileiro. Rio de Janeiro: Rocco, 1997.

DUMONT, Louis. Essais sur l'individualisme: une perspective anthropologigue sur l'idéologie moderne. Paris: Éditions du Seuil, 1983.

ELIAS, Norbert. O Processo Civilizador. Volume 1. Uma História dos Costumes. Rio de Janeiro: Jorge Zahar Editor, 1993.

ELIAS, Norbert. O Processo Civilizador. Volume 2. Formação do Estado e Civilização. Rio de Janeiro: Jorge Zahar Editor, 1990.

FONSECA, Cláudia. Preparando-se para a vida: reflexões sobre a escola e a adolescência em grupos populares. Em Aberto. Brasília, ano 14, n.61, jan/mar, 1994.

FONSECA, Claudia; TERTO JR, Veriano; ALVES, Caleb Farias [orgs]. Antropologia, diversidade e direitos humanos: diálogos interdisciplinares. Porto Alegre: Editora da UFRGS, 2004. 
FOUCAULT, Michel. "Alternatives à la prison: diffusion ou décroissance du contrôle social? Une entrevue avec Michel Foucault" In BRODEUR, Jean-Paul. Revue Criminologie, vol. 26, no 1, 1993, pp. 13-34. Numéro intitulé: "Michel Foucault et la (post)modernité”. Montréal: Les Presses de l'Université de Montréal. 1993.

KANT DE LIMA, Roberto. Cultura Jurídica e Práticas Policiais. A Tradição Inquisitorial. In: Revista Brasileira de Ciências Sociais. No 10, vol. 4, junho de 1989.

MARTIN, Emily. Managing Americans - Policy and changes in the meanings of work and the self. In SHORE, Cris \& WRIGHT, Susan [orgs]. Anthropology of Policy. Critical perspectives on governance and power. Taylor \& Francis e-Library, 2005.

MARTÍNEZ-MORENO, Marco Júlian. Da "cultura de la violência" à "democracia familiar": masculinidade, cultura e conformação da alteridade em uma política pública de Bogotá, Colômbia. Dissertação defendida na Universidade de Brasília. Brasília, 2013.

MAUSS, Marcel. Ensaio sobre a dádiva. Lisboa: Edições 70, 2008.

Portal da Secretaria de Estado de Políticas para Crianças, Adolescentes e Juventude. Núcleo de Atendimento Integrado (NAI). Disponível em $<$ http://www.crianca.df.gov.br/component/content/article/319.htm> Acesso em 15 de abril de 2015.

Portal da Secretaria de Direitos Humanos da Presidência da República. Sistema Nacional de Atendimento Socioeducativo (Sinase). Disponível em $<$ http://www.sdh.gov.br/assuntos/criancas-e-adolescentes/programas/sistema-nacionalde-medidas-socioeducativas/sistema-nacional-de-atendimento-socioeducativo-sinase-1> Acesso em 15 de abril de 2015.

Portal da Secretaria de Direitos Humanos da Presidência da República. Sinase - Plano Nacional de Atendimento Socioeducativo. Disponível em < http://www.sdh.gov.br/assuntos/criancas-e-adolescentes/pdf $>$. Acesso em 15 de abril de 2015. 
Portal da Secretaria de Direitos Humanos da Presidência da República. Atendimento Inicial Integrado. Disponível em http://www.sdh.gov.br/assuntos/criancas-eadolescentes/programas/sistema-nacional-de-medidas-socioeducativas/atendimentoinicial-integrado. Acesso em 15 de abril de 2015.

Portal do Ministério do Desenvolvimento Social e Combate à Fome. Serviço de Proteção Social a Adolescentes em Cumprimento de Medida Socioeducativa de Liberdade Assistida (LA) e de Prestação de Serviços à Comunidade (PSC). Disponível em

$<$ http://www.mds.gov.br/assistenciasocial/protecaoespecial/mediacomplexidade/adolesc entes-em-cumprimento-de-medida>. Acesso em 15 de abril de 2015.

Portal do Ministério da Saúde. Mais sobre os serviços disponíveis em Saúde Mental. Disponível em $\quad$ http://portalsaude.saude.gov.br/index.php/cidadao/acoes-eprogramas/conte-com-a-gente/leia-mais-conte-com-a-agente. Acesso em 02 de maio de 2015.

RIFIOTIS, Theophilos. Judicialização dos direitos humanos, lutas por reconhecimento e políticas públicas no Brasil: configurações de sujeito. In Revista de antropologia, São Paulo, USP, 2014, v. 57 n 1

ROSE, Nicholas. Governing “Advanced" Liberal Democracies. In SHARMA, Aradhana \& GUPTA, Akhil. [orgs]. Anthropology of the State. Australia: BLACKWELL PUBLISHING, 2006.

ROSSATO, Luciano Alves, LÉPORE, Paulo Eduardo, CUNHA, Rogério Sanches. Estatuto da Criança e do Adolescente Comentado. - 2. Ed. Rev., atual. e ampl. - São Paulo: Editora Revista dos Tribunais, 2011.

SCHELIGA, Eva Lenita. Trajetórias religiosas e experiências prisionais: a conversão em uma instituição penal. In INSTITUTO DE ESTUDOS DA RELIGIÃO. Religiões e Prisões, 2005. 
SCHUCH, Patrice. Práticas de Justiça: Uma Etnografia do "Campo de Atenção ao Adolescente Infrator" no Rio Grande do Sul, depois do Estatuto da Criança e do Adolescente. Tese de doutorado defendida na Universidade Federal do Rio Grande do Sul. Porto Alegre, 2005.

SCHUCH, Patrice. Tecnologias da Não Violência e Modernização da Justiça no Brasil: poderes, saberes e éticas. Trabalho escrito para apresentação na $26^{\mathrm{a}}$ Reunião Brasileira de Antropologia, realizada em Porto Seguro/BA, entre $1^{\circ}$ a $4^{\circ}$ de junho de 2008 .

SCHUCH, Patrice. Direitos e sensibilidades: uma etnografia das práticas de justiça da infância e juventude. IN GROSSI, Miriam Pillar, HEILBORN, Maria Luiza e MACHADO, Lia Zanotta [orgs]. Antropologia e direitos humanos. Blumenau : Nova Letra, 2006, 424p. ISBN 85-7682-147-8

SENELLART, Michel \& EWALD, François \& FONTANA, Alessandro. [orgs.] Segurança, território, população: curso dado no Collège de France (1977-1978)/ Michel Foucault. São Paulo: Martins Fontes, 2008.

SHORE, Cris \& WRIGHT, Susan [orgs]. Anthropology of Policy. Critical perspectives on governance and power. Taylor \& Francis e-Library, 2005.

SILVA, Enid Rocha \& OLIVEIRA, Raissa Menezes. Nota Técnica $\mathbf{N}^{\mathbf{0}}$ 20. O Adolescente em Conflito com a Lei e o Debate sobre a Redução da Maioridade Penal: esclarecimentos necessários. Brasília, IPEA, junho de 2015. Disponível em http://www.ipea.gov.br/portal/images/stories/PDFs/notatecnica maioridade penal. Acesso em 21 de junho de 2015.

TAYLOR, Charles. As fontes do self: a construção da identidade moderna. São Paulo: Loyola, 1997.

VELHO, Gilberto. Projeto e metamorfose - antropologia das sociedades complexas. Rio de Janeiro: Jorge Zahar, 1994. 
VIANNA, Andrea. Quem deve guardar as crianças? Dimensões tutelares da gestão contemporânea da infância. In LIMA, Antonio Carlos de Souza [org.]. Gestar e gerir : estudos para uma antropologia da administração pública no Brasil. Rio de Janeiro: Relume Dumará: Núcleo de Antropologia da Política/UFRJ, 2002

WEBER, Max. A ética protestante e o espírito do capitalismo. São Paulo: Companhia das Letras, 2004. 